\title{
Data Report: Resource Ratings of the Rare II Tracts in the Idaho-Wyoming-Utah and the Central Appalachian Thrust Belts
}
A. H. Voelker
H. Wedow
E. Oakes
P. K. Scheffler

\section{OPERATED BY}

UNION CARBIDE CORPORATION FOR THE UNITED STATES DEPARTMENT OF ENERGY 


\section{DISCLAIMER}

This report was prepared as an account of work sponsored by an agency of the United States Government. Neither the United States Government nor any agency Thereof, nor any of their employees, makes any warranty, express or implied, or assumes any legal liability or responsibility for the accuracy, completeness, or usefulness of any information, apparatus, product, or process disclosed, or represents that its use would not infringe privately owned rights. Reference herein to any specific commercial product, process, or service by trade name, trademark, manufacturer, or otherwise does not necessarily constitute or imply its endorsement, recommendation, or favoring by the United States Government or any agency thereof. The views and opinions of authors expressed herein do not necessarily state or reflect those of the United States Government or any agency thereof. 


\section{DISCLAIMER}

Portions of this document may be illegible in electronic image products. Images are produced from the best available original document. 


\section{Printed in the United States of America. Available from National Technical Information Service \\ U.S. Department of Commerce 5285 Port Royal Road, Springfield, Virginia 22161 NTIS price codes-Printed Copy: A08 Microfiche A01}

This report was prepared as an account of work sponsored by an agency of the United States Government. Neither the United States nor any agency thereof, nor any of their employees, makes any warranty, expressed or implied, or assumes any legal liability or responsibility for any third party's use or the results of such use of any information, apparatus, product or process disclosed in this report, or represents that its use by such third party would not infringe privately owned rights. 
Contract No. W-7405-eng-26

REGIONAL AND URBAN STUDIES

ENERGY DIVISION

DATA REPORT; RESOURCE RATINGS OF THE RARE II TRACTS IN THE IDAHO-WYOMING-UTAH AND THE CENTRAL APPALACHIAN THRUST BELTS
A. H. Voelker
H. Wedow
E. Oakes ${ }^{\dagger}$
P. K. Scheffler

\footnotetext{
*Independent geologist.

†Science Applications, Inc.

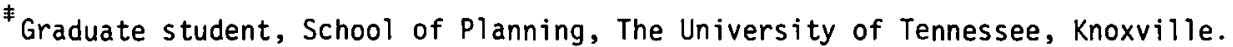

Date Published: November 1979

OAK RIDGE NATIONAL LABORATORY

Oak Ridge, Tennessee 37830

uperaled by

UNION CARBIDE CORPORATION

for the

DEPARTMENT OF ENERGY

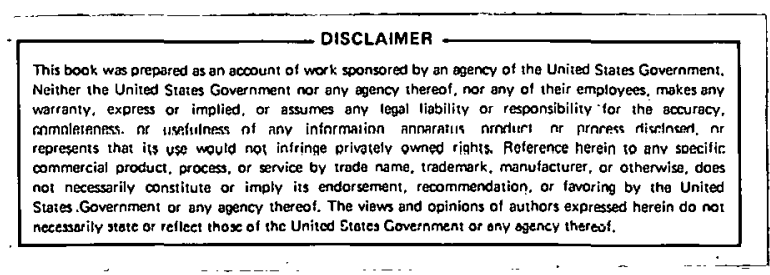




\section{THIS PAGE}

WAS INTENTIONALLY

LEFT BLANK 
CONTENTS

Page

ABSTRACT .......................................

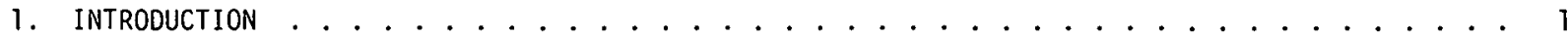

2. WESTERN SECTION

2.1 Description of the Idaho-Wyoming-Utah Thrust Belt . . . . . . . . . . . . . . . . 3

2.2 Explanation of headings used on assessment form . . . . . . . . . . . . . . . . 4

2.3 Assessment Forms for Idaho-Wyoming-Utah Thrust Beit . . . . . . . . . . . . . . . . . 5

3. EASTERN SECTION . . . . . . . . . . . . . . . . . . . . . . . . 71

3.1 Description of the Central Appalachians . . . . . . . . . . . . . . . . . 71

3.2 Assessment Forms for Central Appalachian Thrust Belt . . . . . . . . . . . . . . . . 73 
DATA REPORT: RESOURCE RATINGS OF THE RARE II TRACTS IN THE IDAHO-WYOMING-UTAH AND THE CENTRAL APPALACHIAN THRUST BELTS

\author{
A. H. Voelker \\ H. Wedow \\ E. Oakes \\ P. K. Scheffler
}

ABSTRACT

\begin{abstract}
The assessment forms contained in this report constitute the data used in two resource assessments described in A Systematic Method for Resource Rating with Two Applications to Potential Wilderness Areas (Voelker et al. 1979). The assessments were performed for two geologic subprovinces containing proposed wilderness areas identified in the Forest Service Ruadless Area Review and Evaluation (RARE II) program. The subprovinces studied are the Idaho-Wyoming-Utah thrust belt and the central Appalachians thrust belt.

Each assessment form contains location data, resource ratings, and supporting information for a single tract. A unique dual rating that reflects geologic favorability and certainty of resource occurrence is assigned to each resource category evaluated. Individual ratings are synthesized into an overall tractimportance rating. Ratings created by others are included for comparative purposes wherever available. Supporting information consists of commentary and references that explain and document the ratings listed.
\end{abstract}

\section{INTRODUCTION}

This report serves as a companion document to $A$ Systematic Method for Resource Rating with Two Applications to Potential Wilderness Areas (Voelker et al., ORNL/TM-6739, 1979), which describes a new method for assessing the resource potential of undeveloped regions. This report contains the data generated by our assessment team as they rated the resource potential of 135 tracts of 1 and identified by the Forest Service as candidates for wilderness designation under the Roadless Area Review and Evaluation (RARE II) Program. We have choosen to publish this voluminous collection of data to permit prospective users of the method to test the validity and reliability of its output. Additionally, because the data is tract specific and represents a relatively complete description of each tract, including ratings, it should be of use to the various groups participating in the current Congressional debate over wilderness designation.

The data are recorded on individual tract assessment forms. Each form contains location. information, resource ratings, and supporting information. A unique dual rating is recorded for each resource reflecting favorability of the geologic environment of the tract for significant deposits of the resource and the certainty of resource occurrence from actual data. Favorability and certainty are rated between 1 ( $10 \mathrm{w}$ ) and 4 (high). Thus, a $4 / 1$ rating indicates that the tract is highly favorable for the resource but that no direct evidence has been collected to prove its existence. For precise definitions of each rating level, see the companion report (Voelker et al., 1979).

Using these dual ratings, a set of predetermined criteria, and the supporting data, the assessment team rated the overall importance of each tract in satisfying future resource needs. criteria were based on such things as the strategic importance and supply of minerals, favorability and certainty, tract size, and other uses of each tract for energy-related activities such as transmission lines or pipelines.

Ratings produced by others are also listed on the form and give the team an additional 
piece of information in reaching its conclusions. Supporting information in the form of comments and references acts as additional data to the decision maker but also shows the basis for the rating decision made by the team. The form allows a complete trace of the rating decision.

The two regions shown in Fig. 1 were assessed with the method. Primary interest centered on the Idaho-Wyoming-Utah thrust belt because of its high potential for oil and gas. The central Appalachians thrust belt was selected as a check on the method because this region has gross geologic similarity to the western region. Assessment forms in this report are grouped by. subprovince, and each section is prefaced with a description of the subprovince.

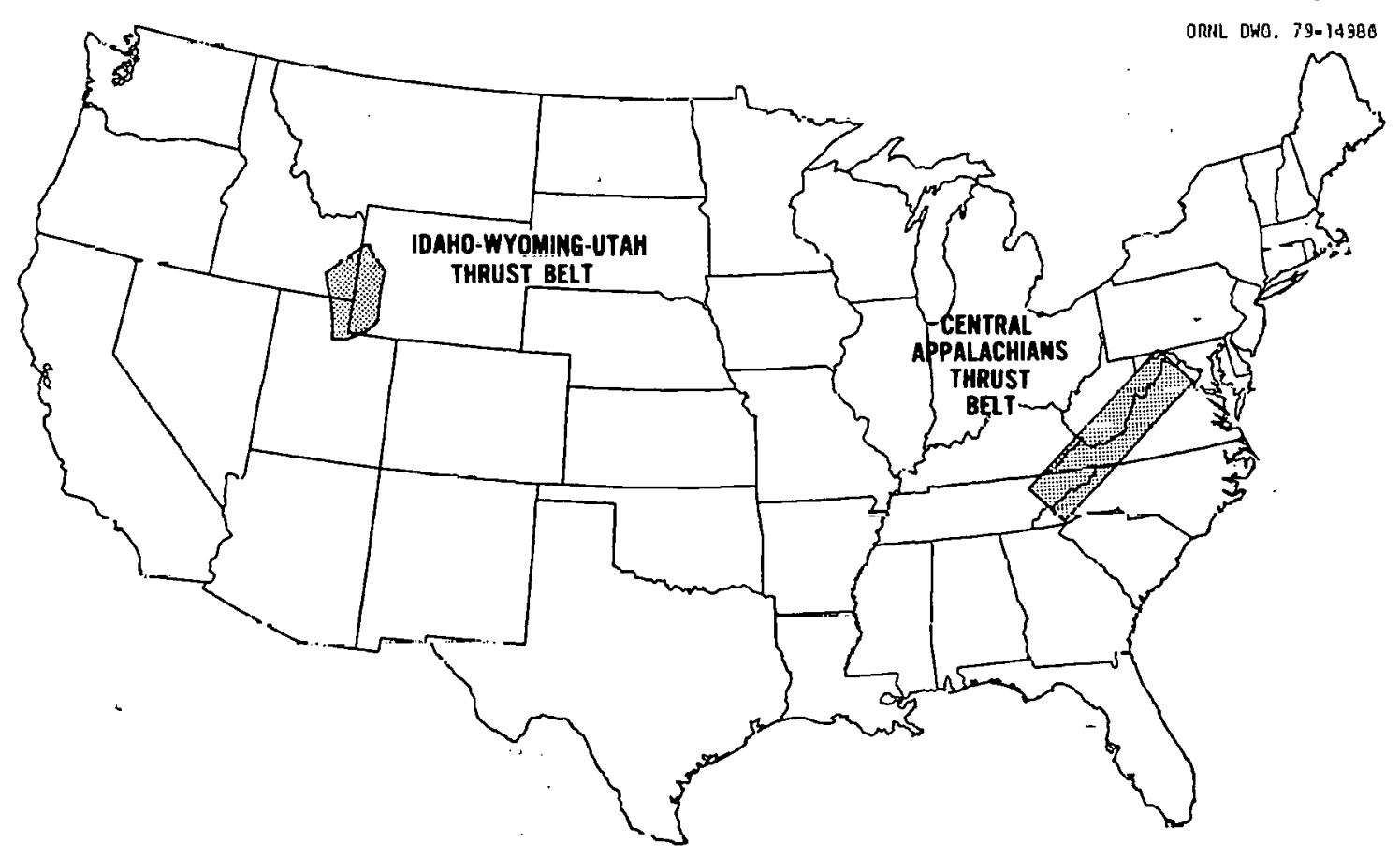

Fig. 1. The Idaho-Wyoming-Utah and the central Appalachian thrust belt study areas. 


\section{WESTERN SECTION}

\subsection{Description of the Idaho-Wyoming-Utah Thrust Belt}

The Idaho-Wyoming-Utah thrust belt was selected for study because it is considered to be the most controversial of all the areas affected by RARE II. The region has a high potential for energy and mineral resources as well as for wilderness.

The Idaho-Wyoming-Utah thrust belt, as considered in this report, is shown in Fig. 2. It is bounded on the north by the Snake River volcanic plain, on the east by the line projected northward along and beyond the trace of the crest of the Moxa arch, on the south by the North Flank fault of the Unita Mountains, and on the west by the Wasatch fault. The area comprises about $23,700 \mathrm{sq}$ miles, or 15 million acres. The Forest Service has identified 63 RARE II tracts in the area, totaling about 3.1 million acres.

The Idaho-Wyoming-Utah thrust belt consists of a west-thickening wedge of Paleozoic and Mesozoic rocks that were thrust eastward from latest Jurassic to Eocene time. From a regional standpoint, this thrust belt is a small segment of the continent-long Cordilleran thrust and fold belt that stretches from Alaska to Mexico. Although the thrust structures are numerous and quite complex in detail, for the purposes of Lhis report we have divided the thrust belt into four areas, which, from east to west, are:

(1) Footwazl, located between the Moxa arch and the trace of the Prospect-Darby thrust,

(2) Prospect-Darby thrust sheet, which extends westward to the trace of the Absaroka thrust,
(3) Absaroka thrust sheet, which is the largest division and extends westward to the trace of the Paris-Bannock thrust, and

(4) Paris-Bannock thrust sheet, which extends westward to the Wasatch fault.

Strictly speaking, the Gros Ventre Mountains and the Grand Tetons are not part of the IdahoWyoming-Utah thrust belt, but their mineral resources were nevertheless assessed.

\subsection{Explanation of Headings Used on Assessment Form}

TRACT N0: Number assigned to Roadless Area by U.S. Forest Service (USFS).

ECOREG: The ecological region in which the tract lies.

WAR: The Wilderness Attribute Rating assigned to the tract by the USFS.

$100 \mathrm{~N} / \mathrm{G}$ : The ratio of new acreage to gross acreage. This ratio is a relative measure of the private land within the tract.

OVERALL RATING (WEIGHTED): The overall energy importance rating of the tract. "Weighted" indicates that criteria in addition to the resource ratings were used to determine the overall rating.

NAMES OF CRITICAL MINERALS PRESENT: In many cases, the symbol for the element or dominant element is shown rather than the name of a specific mineral. For exampie, $P(V, U, F, Z n, C d, C r)$ indicates that the tract contains phosphate rock, which is high in vanadium, uranium, fluorine, zinc, cadmium, and chromium. 
ORNL DWG 78-16330

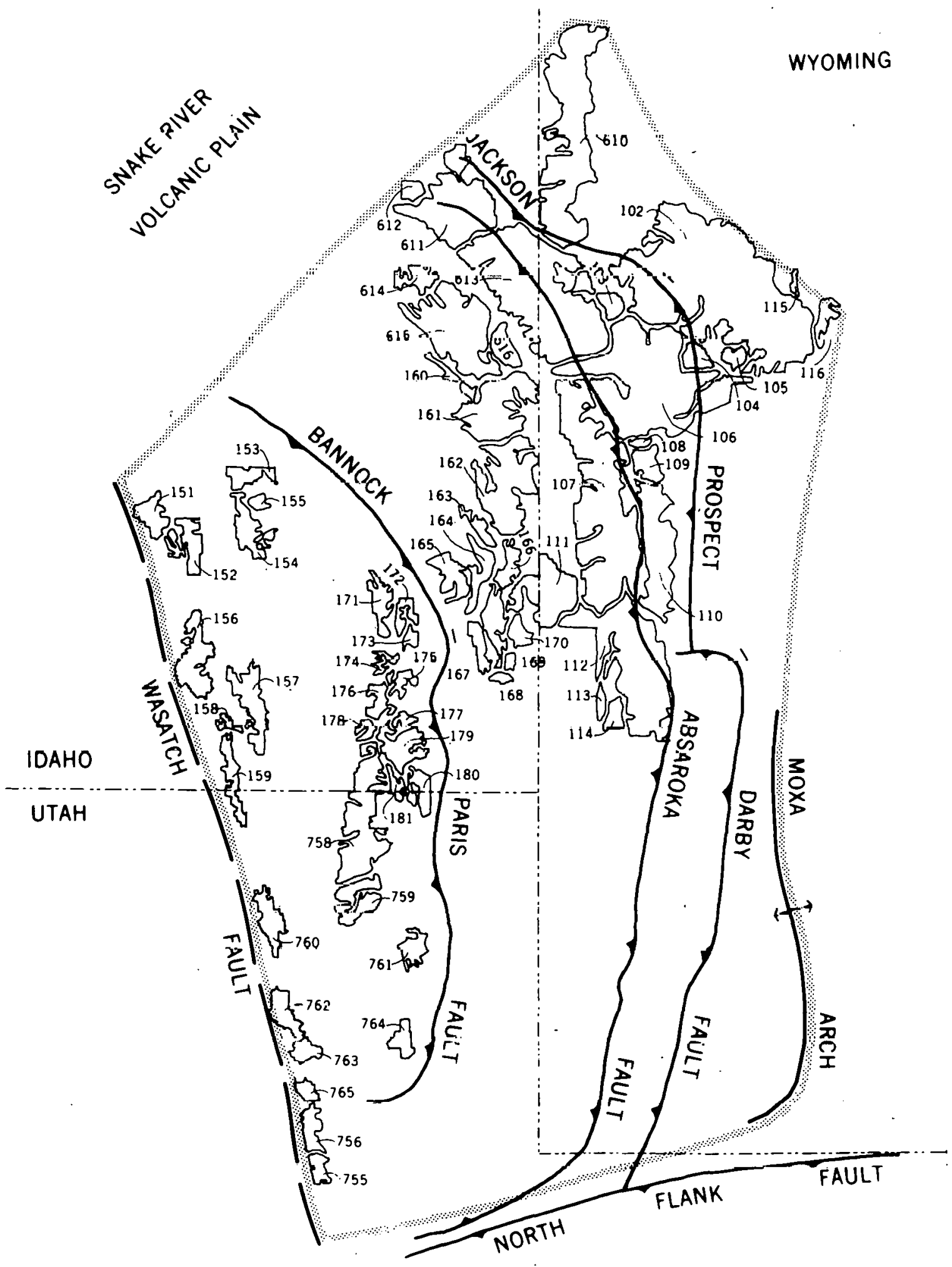

Fig. 2. RARE II tracts in the Idaho-Wyoming-Utah thrust belt. 
9

2.3 Assessment Fornus for Idaho-Wyoming-

Utah Thrust Belt 


\section{THIS PAGE \\ WAS INTENTIONALLY \\ LEFT BLANK}


ENERGY AND MINERAL RESOURCE EVALUATION - RARE II TRACTS

TRACT NO: 04102

TRACT NAME: Gros Ventre

ECOREG: 3112

WAR: 24

NATIONAL FOREST: Bridger-Teton

STATE/COUNTY: Wyoming, Teton/Sublette

ACREAGE (GROSS): 435,320 ACREAGE (NET): $432,600100 \mathrm{~N} / \mathrm{G}: 99$ LATITUDE: $43^{\circ} 25^{\prime}$ LONGITUDE: $110^{\circ} 25^{\circ}$

$\begin{aligned} & \text { INDIVIDUAL TRACT } \\ & \text { RESOURCE RATINGS }\end{aligned}$ ORNL
OIL AND GAS

GEOLOGY: Footwall Belt of the Jackson-Prospect-Darby fault system (extends eastward to the crest of the Moxa Arch and its northward projection). Surface rocks are largely Tertiary in age, except in the north where the Gros Ventre, West Slope of the Tetons, and several smailer satellite Rare II.tracts r.nnt.ain the entire regional stratiquaphic sequence from Precambrian through Cenzoic.

REFERENCE/CITATION: USFS, 1978, RARE II DES, ID, UT, and WY Suppls.; DOE, 1978, Energy Res. Assessments of RARE II Lands; DOE, 1978, Energy Res. Assessments, of Ten Alternatives-RARE II Lands; Powers, 1977, WGA Gdbk 29; Blackstone, 1978, Tectonic Map of the Overthrust Be1t: WGS; RMOGA, 1978, Estimates of Undiscovered Recoverable Hydrocarbon Resources (RARE-II); White and Williams, 1975, USGS Circ. 726 ; NOAA, 1977, Geothermal Energy Resources of the Western U.S.; USGS, 1945, Min. Res. Mo. Va'lley Region, Pts 1, 2, 3; ERDA, 1976, NURE-Prel im. Rpt.; Armstrong and Oriel, 1965, AAPG Bull., v. 43; British Sulfur Corp., Ltd., 1964, A world survey of phosphate deposits: Woodalls Ltd. (Printers), London; Gulbrandsen, 1966, Geochim. Cosmochim. Acta, v. 3, 769-778; Brobst and Pratt, 1973, USGS Prof. Paper 820; Worl and 0thers, 1974, USGS MR-60; Kinkel and Peterson, 1962, USGS MR-13; RMAG, 1972, Geologic Atlas of the Rocky Mountain Region: Denver, C0; Love and Others, 1955, Geologic Map of Wyoming: USGS; Glass and Others, 1975, Energy Resources Map of Wyoming: WGS; She1don, 1965, USGS Prof. Paper 1313-B; Clabough and others, 1946, USGS Mo. Bas in Studies No. 9; USGS, 1964, MR-42; Chidester and Worthington, 1962, USGS MR-31; Love, 1961, USGS Prof. Paper 424-C; Chidester and Shride, 1962, USGS MR-17. 
ENERGY AND MINERAL RESOURCE EVALUATION - RARE II TRACTS

TRACT NO: 04103

TRACT NAME: Munger Mountain

ECOREG: 3112

WAR: 16

NATIONAL FOREST: Bridger-Tetor

STATE/COUNTY: Wyoming, Teton

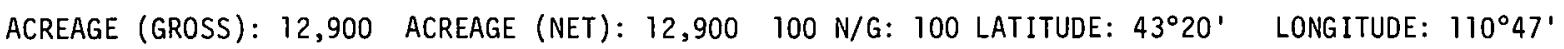

INDIVIDUAL TRACT

RESOURCE RATINGS

OIL AND GAS

$\underline{\text { ORNL }}$

$\underline{\text { USFS }}$

DOE USGS

$\begin{array}{lll}4 / 3 & 4 & 4\end{array}$

URANIUM

COAL

GEOTHERMAL

CRITICAL MINERALS

OVERALL RATING

(WEIGHTED)

\section{$2 / 1$}

$1 / 3$

$3 / 2$

$4 / 2$

3
REMARKS

Stratigraphic and structural traps compounded by thrusting; similar to Canadian Rockies Foothills Belt

NAMES OF CRITICAL MINERALS PRESENT: $P(U, V, F, Z n, C d, C r)$

COMMENTARY AND SUMMARY: The westward part of the La Barge hydrocarbon s.nmplex extends heneath the Jackson-Hrospect-Darby Fauit in the central part of the belt, and several smaller relatively shallow fields occur in the southern part of the belt. The Rocky Mountain $0 i 1$ and Gas Association estimates that over 800 million barrels of oil and nearly five trillion cubic feet of gas occur in the Rare II tracts or parts thereof in the Jackson-Prospect-Darby thrust belt. Significant phosphate resources along with by-product potential in uranium, vanadium, chromium and other critical minerals occur in this belt. DOE, ' 4 ' for hydro-minor conflict.

GEOLOGY: Jackson-Prospect-Darby thrust belt (includes terrain westward to the surface trace of the Absaroka Fault). Surface strata are dominantly Cretaceous through Devonian in age, although locally some Lower Paleozoic rocks are exposed along the Footwall Fault, and some areas are covered by younger Tertiary sediment.s.

REFERENCE/CITATION: USFS, 1978, RARE II DES, ID, UT, and WY Suppls.: DOE, 197R, Fnergy Res. Assessmente of KARE 1I. Lands; DOE, 1978, Energy Res. Assessments, of Ten Alternatives-RARE II Lands; Powers, 1977 , WGA Gdbk 29; Blackstone, 1978, Tectonic Map of the Overthrust Belt: WGS; RMOGA, 1978, Estimates of Undiscovered Recoverabile Hydrocarbon Resources (RARE-II); White and Williams, 1975, USGS CirC. 726 ; NOAA, 1977, Geothermal Energy Resources of the Western U.S.; USGS, 1945, Min. Res. Mo. Valley Region, Pts 1, 2, 3; ERDA, 1976, NURE-Prelim. Rpt.; Armstrong and Oriel, 1965, AAPG Bull., v. 43; British Sulfur Corp., Ltd., 1964, A world survey of phosphate deposits: Woodalls Ltd. (Printers), London; Gulbrandsen, 1966, Geoch im. Cosmochim. Acta, v. 3, 769-778; Brobst and Pratt, 1973, USGS Prof. Paper 820; Worl and Others, 1974, USGS MR-60; Kinkel and Peterson, 1962, USGS MR-13; RMAG, 1972, Geologic Atlas of the Rocky Mountain Region: Denver, CO; Lnve and 0thers, 1955, Geologic Map of Wyoming: USGS; Glass and Others, 1975, Energy Resources Map of Wyoming: WGS; Sheldon, 1965, USGS Prof. Paper 1313-B; Clabough and others, 1946, USGS Mo. Bas in Studies No. 9; USGS, 1964, MR-42; Chidester and Worthington, 196', USGS MR-31; Love, 1961, USGS Prof. Paper 424-C; Chidester and Shride, 1962, USGS MR-17. 
ENERGY AND MINERAL RESOURCE EVALUATION - RARE II TRACTS

TRACT NO: 04104

TRACT NAME: Monument Ridge

ECOREG: 3112

WAR: 15

NATIONAL FOREST: Bridger-Teton

STATE/COUNTY: Wyoming, Sublette

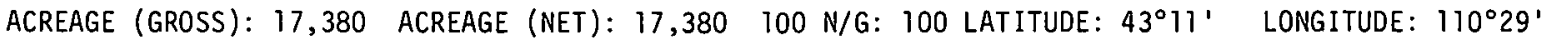

INDIVIDUAL TRACT

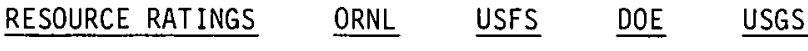

OIL AND GAS

$\begin{array}{lll}4 / 4 & 4\end{array}$

URAN IUM

COAL

$3 / 1$

$4 / 3$

1

GEOTHERMAL

$2 / 2$

1

CRITICAL MINERALS

$3 / 2$

4

OVERALL RATING

(WEIGHTED)

4-

4

NAMES OF CRITICAL MINERALS PRESENT: $P(U, V, F, Z n, C d, C r)$

COMMENTARY AND SUMMARY: Part of the large La Barge hydrocarbon complex with the àssociated Greater Big Piney Gas Area is located in the central, part of the Footwall Belt. Numerous smaller oil and/or gas fields also occur along nearly the entire length of the belt and include a recent major gas discovery in Teton County in a roaded salient extending deep into Rare II tract 4102 . Over 200 million barrels of oil and nearly 15 trillion cubic feet of gas have been estimated by the Rocky Mountain $0 i 1$ and Gas Association for Rare II tracts in this belt. The Permian Phosphoria Formation contains part of the region's large phosphate resources.

GEOLOGY: Footwall Belt of the Jackson-Prospect-Darby fault system (extends eastward to the crest of the Moxa Arch and its northward projection). Surface rocks are largely Tertiary in age, except in the north where the Gros Ventre, West Slope of the Tetons, and several smaller satellite Rare II tracts contain the entire rogional stratigraphic sequence from Prẹsamhrian through Cenzoic.

REFERENCE/CITATION: USFS, 1978, RARE II DES, ID, UT, and WY Supp1s.; DOE, 1978, Energy Res. Assessments of RARE II Lands; DOE, 1978, Energy Res. Assessments, of Ten Alternatives-RARE II Lands; Powers, 1977 , WGA Gdbk 29; Blackstone, 1978, Tectonic Map of the Overthrust Belt: WGS; RMOGA, 1978, Estima tes of Undiscovered Recoverable Hydrocarbon Resources (RARE-II); White and Williams, 1975, USGS Circ. 726; NOAA, 1977, Geothermal Energy Resources of the Western U.S.; USGS, 1945, M1n. Res. Mo. VaTley Region, Pts 1, 2, 3; ERDA, 1976, NURE-Prelim. Rpt.; Armstrong and Oriel, 1965, AAPG Bul1., v. 43; British Sulfur Corp., Ltd., 1964, A world survey of phosphate deposits: Woodalls Ltd. (Printers), London; Gulbrandsen, 1966, Geochim. Cosmochim. Acta, v. 3,769-778; Brobst and Pratt, 1973, USGS Prof. Paper 820; Worl and Others, 1974, USGS MR-60; Kinkel and Peterson, 1962, USGS MR-13; RMAG, 1972, Geologic Atlas of the Rocky Mountain Region: Denver, CO; Love and Others, 1955; Geologic Map of Wyoming: USGS; Glass and Others, 1975, Energy Resources Map of Wyoming: WGS; Sheldon, 1965, USGS Prof. Paper 1313-B; Clabough and others, 1946, USGS Mo. Basin Studies No. 9; USGS; 1964, MR-42; Chidester and Worthington, 1962, USGS MR-31; Love, 1961, USGS Prof. Paper 424-C; Chidester and Shride, 1962, USGS MR-17. 
ENERGY AND MINERAL RESOURCE EVALUATION - RARE II TRACTS

TRACT NO: 04105

TRACT NAME: Jenny Creek

ECOREG: 3112

WAR: 16

NAIIONAL FOREST: Bridger-Teton

STATE/COUNTY: Wyoming, Sublette

ACREAGE (GROSS): 11,110 ACREAGE (NET): $11,110 \quad 100 \mathrm{~N} / \mathrm{G}: 100$ LATITUDE: $43^{\circ} 11^{\prime}$ LONGITUDE: $110^{\circ} 21^{\prime}$

INDIVIDUAL TRACT RESOURCE RATINGS

$\underline{\text { ORNL }} \underline{\text { USFS }} \underline{\text { DOE }} \underline{\text { USGS }}$

REMARKS

$\begin{array}{lllll}\text { OIL AND GAS } & 1 / 4 & 1 & 1 & \begin{array}{l}\text { Stratigraphic } \\ \text { pounded by th } \\ \text { Puckior Footh }\end{array} \\ \begin{array}{l}\text { URANIUM } \\ \text { COAL }\end{array} & 3 / 1 & 1 & 1 & \text { Subuitumillous } \\ \begin{array}{l}\text { GEOTHERMAL } \\ \text { CRITICAL MINERALS }\end{array} & 4 / 4 & 1 & 1 & \\ \begin{array}{l}\text { OVERALL RATING } \\ \text { (WEIGHTED) }\end{array} & 2 / 2 & 1 & & \end{array}$

NAMES OF CRITICAL MINERALS PRESENT:

COMMENTARY AND SUMMARY: Part of the large La Barge hydrocarbon complex with the associated Greater Big Piney Gas Area is located in the central part of the Footwall Belt. Numerous smaller oil and/or gas fields also occur along nearly the entire length of the belt and include a recent major gas discovery in Teton County in a roaded salient extending deep into Rare II tract 4102 . Over 200 million barrels of oil and nearly 15 trillion cubic feet of gas have been estimated by the Rocky Mountain 0il and Gas Association for Rare II tracts in this belt. The Permian Phosphoria Formation contains part of the region's large phosphate resources.

GEOLOGY: Footwall Belt of the Jackson-Prospect-Darby fault system (extends eastward to the crest of the Moxa Arch and its northward projection). Surface rocks are largely Tertiary in age, except in the north where the Gros Ventre, West Slope of the Tetons, and several smaller satellite Rare II tracts contain the entire regional stratigraphic sequence from Precambrian through Cenzoic.

REFERENCE/CITATION: USFS, 1978, RARE II DES, ID, UT, and WY Suppls.; DOE, 1978, Energy Res. Assessments of RARE II Lands; DOE, 1978, Energy Res. Assessments, of Ten Alternatives-RARE II Lands; Powers, 1977 , WGA Gdbk 29; Blackstone, 1978, Tectonic Map of the Overthrust Be1t: WGS; RMOGA, 1978, Estimates of Undiscovered Recoverable Hydrocarbon Resources (RARE-II); White and Williams, 1975, USGS Circ. 726; NOAA, 1977, Geothermal Energy Resources of the Western U.S.; USGS, 1945, Min. Res. Mo. Valley Region, Pts i, 2, 3; ERON, 1976, NURE-Prcl1m. Rpt.; Armstrong and Orie1, 1965, AAI'G Bul1., V. 43; British Sulfur Corp., Ltd., 1964, A world survey of phosphate deposits: Woodalls Ltd. (Printers), London; Gulbrandsen, 1966, Geochim. Cosmochim. Acta, v. 3, 769-778; Brobst and Pratt, 1973, USGS Prof. Paper 820; Worl and 0thers, 1974, USGS MR-60; Kinke1 and Peterson, 1962, USGS MR-13; RMAG, 1972, Geologic Atlas of the Rocky Mountain Region: Denver, CO; Love and Others, 1955, Geologic Map of Wyoming: USGS; Glass and Others, 1975, Energy Resources Map of Wyoming: WGS; Sheldon, 1965, USGS Prof. Paper 1313-B; Clabough and others, 1946, USGS Mo. Bas in Studies No. 9; USGS, 1964, MR-42; Chidester and Worthington, 1962, USGS MR-31; Love; 1961, USGS Prof. Paper 424-C; Chidester and Shride, 1962, USGS MR-17. 
INÜIVIDUAL TRACI RESOURCE RATINGS

OIL AND GAS $\underline{\text { ORNL }} \underline{\text { USFS }} \quad \underline{D O E} \quad \underline{\text { USGS }}$

$\begin{array}{lccc}\text { OIL AND GAS } & 4 / 3 & 4 & 4 \\ \text { URANIUM } & 3 / 1 & 4 & 1 \\ \text { COAL } & 4 / 4 & 4 & 3 \\ \text { GEOTHERMAL } & 3 / 2 & 1 & \\ \text { CRITICAL MINERALS } & 4 / 3 & 4 & \\ \begin{array}{l}\text { OVERALL RATING } \\ \text { (WEIGHTED) }\end{array} & 4 & \end{array}$

NAMES OF CRITICAL MINERALS PRESENT: $\mathrm{P}(\mathrm{U}, \mathrm{V}, \mathrm{F}, \mathrm{Zn}, \mathrm{Cd}, \mathrm{Cr}) ; \mathrm{Ti}$

COMMENTARY AND SUMMARY: The westward part of the La Barge hydrocarbon complex extends beneath the Jackson-Prospect-Darby Fault in the central part of the belt, and several smaller relatively shallow fields occur in the southern part of the belt. The Rocky Mountain 0il and Gas Association estimates that over 800 million barrels of oil and nearly five trillion cubic feet of gas occur in the Rare II tracts or parts thereof in the Jackson-Prospect-Darby thrust belt. Significant phosphate resources along with by-product potential in uranium, vanadium, chromium and other critical minerals occur in this belt. DOE, ' 4 ' for hydro-border conflict.

GEOLOGY: Jackson-Prospect-Darby thrust belt (includes terrain westward to the surface trace of the Absaroka Fault). Surface strata are dominantly Cretaceous through Devonian in age, although locally some Lower Paleozoic rocks are exposed along the Footwall Fault, and some areas are covered by younger Tertiary sediments.

REFERENCE/CITATION: USFS, 1978, RARE II DES, ID, UT, and WY Suppls.; DOE, 1978, Energy Res. Assessments of RARE II Lands; D0E, 1978, Energy Res. Assessments, of Ten Alternatives-RARE II Lands; Powers, 1977 , WGA Gdbk 29; Blackstone, 1978, Tectonic Map of the Overthrust Belt: WGS; RMOGA, 1978, Estimates of Undiscovered Recoverable Hydrocarbon Resources (RARE-II); White and Williams, i975, USGS Circ. 726 ; NOAA, 1977, Geothermal Energy Resources of the Western U.S.; USGS, 1945, Min. Res. Mo. Valley Region, Pts 1, 2, 3; ERDA, 1976, NURE-Prelim. Rpt.; Armstrong and Oriel, i965, AAPG Bull., v. 43; British Sulfur Corp., Ltd., 1964, A world survey of phosphate deposits: Woodalls Ltd. (Printers), London; Gulbrandsen, 1966, Geochim. Cosmochim. Acta, v. 3, 769-778; Brobst and Pratt, 1973, USGS Prof. Paper 820; Worl and Others, 1974, USGS MR-60; Kinkel and Peterson, 1962, USGS MR-13; RMAG, 1972, Geologic Atlas of the Rocky Mountain Region: Denver, CO; Love and Others, 1955, Geologic Map of Wyoming: USGS; Glass and Others, 1975, Energy Resources Map of Wyoming: WGS; Sheldon, 1965, USGS Prof. Paper 1313-B; Clabough and others, 1946, USGS Mo. Basin Studies No. 9; USGS, 1964, MR-42; Chidester and Worthington, 1962, USGS MR-31; Love, 1961, USGS Prof. Paper 424-C; Chidester and Shride, 1962, USGS MR-17. 
ENERGY AND MINERAL RESOURCE EVALUATION - RARE II TRACTS

TRACT NO: 04107

TRACT NAME: Salt River Range

ECOREG : 3112

WAR: 22

NATIONAL FOREST: Bridger-Teton

STATE/COUNTY: Wyoming, Lincoln

ACREAGE (GROSS): 259,270 ACREAGE (NET): $256,390100 \mathrm{~N} / \mathrm{G}: 99$ LATITUDE: $42^{\circ} 46^{\prime}$ LONGITUDE: $110^{\circ} 48^{\prime}$

\begin{tabular}{|c|c|c|c|}
\hline $\begin{array}{l}\text { INDIVIDUAL TRACT } \\
\text { RESOURCE RATINGS } \\
\end{array}$ & ORNL & USFS & $\underline{D O E}$ \\
\hline OIL AND GAS & $4 / 3$ & 4 & 4 \\
\hline URANIUM & $2 / 1$ & 4 & 1 \\
\hline CONL & $4 / 4$ & 4 & 3 \\
\hline GEOTHERMAL & $2 / 2$ & 1 & \\
\hline CRITICAL MINERALS & $4 / 3$ & 4 & \\
\hline $\begin{array}{l}\text { OVERALL RATING } \\
\text { (WEIGHTED) }\end{array}$ & 4 & & 4 \\
\hline
\end{tabular}

Stratigraphic and etructural traps compounded by thrusting; similar to Canadian Rockies Foothilis Belt

NAMES OF CRITICAL MINERALS PRESENT: $P(U, V, F, \mathrm{Zn}, \mathrm{Cd}, \mathrm{Cr}$ )

COMMENTARY AND SUMMARY: Several major and several lesser oil and/or gas fields are located in the southern part of the Absaroka Belt in Wyoming and Utah. Most production is from Jurassic-Triassic reservoirs, but more recent deeper discoveries are in Upper Paleozoic rocks (Phosphoria) and even more recently in Lower Paleozoic rocks. The Rocky Mountain 0 il and Gas Association estimates that Rare II tracts in the Absaroka belt contain nearly 3.3 billion barrels of oil and over 12.5 trillion cubic feet of gas. The major part of the Southeast Idaho phosphate resource is in this thrust belt, with much of it in the Rare II tracts. Not only are the phosphate rock resources important for the phosphorus, but there is a significant near-future potential for vanadium, uranium by-product. production. The Mt. Pisgah gold district in Bonnevilie County may have significant potential for Carlin-type gold deposits (Rare II tracts 04160, 04161, and 04162). DOE, 2 for hydro-minor conflict.

GEOLOGY: Absaroka thrust belt (includes terrain westward to surface trace of the Paris-Bannock thrust complex). Includes (as secondary structures) the Crawford, Meade, Medicine Lodge, Sheep Mountain, Skyline, and many smaller thrust faults. Rocks exposed at the surface include sedimentary rocks from Cambrian to Tertiary in age along with some Tertiary and Quaternary volcanics. Several small igneous intrusions of Tertiary Age have been mapped in the Idaho part of the Absaroka Belt, chiefly in the vicinity of the Mt. Pisgah gold district.

REFERENCE/CITATION: USFS, 1978, RARE II DES, ID, UT, and WY Suppls.; DOE, 1978, Energy Res. Assessments of KAKt 11 Lands; UUt, Iy/8, Energy Res. Assessments, of Ten Alternatives-RARE II Lands; Powers, 1977 , WGA Gdbk 29; Blackstone, 1978, Tectonic Map of the Overthrust Belt: WGS; RMOGA, 1978, Estimates of Undiscovered Recoverable Hydrocarbon Resources (RARE-II); White and Williams, 1975, USGS Circ. 726; NOAA, 1977, Geothermal Energy Resources of the Western U.S.; USGS, 1945, Min. Res. Mo. Valley Region, Pts 1, 2, 3; ERDA, 1976, NURE-Prelim. Rpt.; Armstrong and Oriel, 1965, AAPG Bull., v. 43; British Sulfur Corp., Ltd., 1964, A world survey of phosphate deposits: Woodalls Ltd. (Printers), London; Gulbrandsen, 1966, Geochim. Cosmochim. Acta, v. 3, 769-778; Brobst and Pratt, 1973, USGS Prof. Paper 820; Worl and Others, 1974, USGS MR-60; Kinkel and Peterson, 1962, USGS MR-13; RMAG, 1972, Geolog ic Atlas of the Rocky Mountain Region: Denver, CO; Love and Others, 1955, Geologic Map of Wyoming: USGS; Glass and 0thers, 1975, Energy Resources Map of Wyoming: WGS; Sheldon, 1965, USGS Prof. Paper 1313-B; Clabough and others, 1946, USGS Mo. Bas in Studies No. 9; USGS; 1964, MR-42; Chidester and Worthington, 1962, USGS MR-31; Love, 1961, USGS Prof. Paper 424-C; Chidester and Shride, 1962, USGS MR-17. 


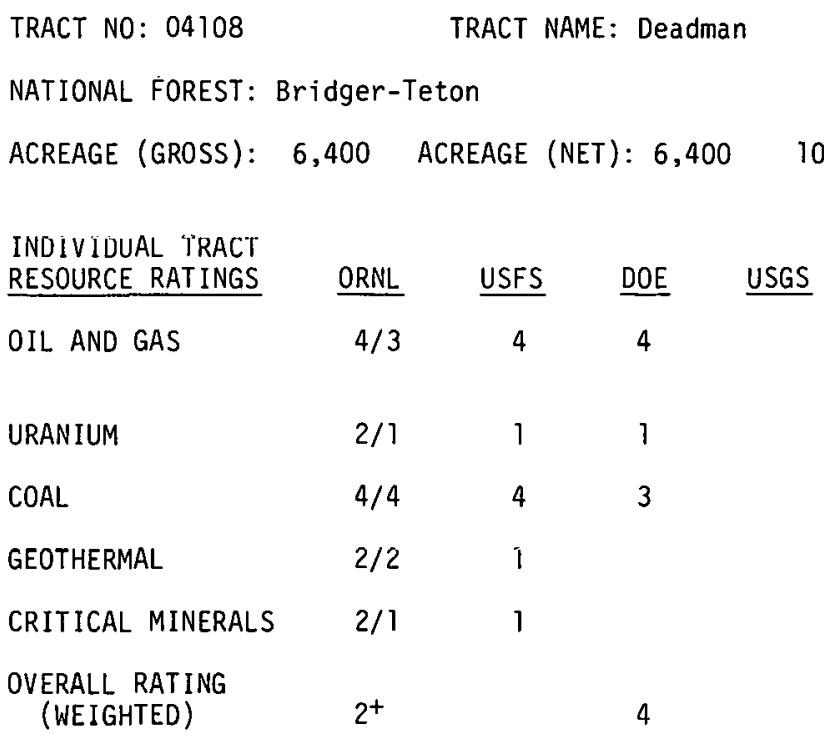

ECOREG: 3112

WAR: 18

STATE/COUNTY: Wyoming, Lincoln

$100 \mathrm{~N} / \mathrm{G}: 100$ LATITUDE: $42^{\circ} 57^{\prime} \quad$ LONGITUDE: $110^{\circ} 40^{\prime}$

NAMES OF CRITICAL MINERALS PRESENT: P?

COMMENTARY AND SUMMARY: The westward part of the La Barge hydrocarbon complex extends beneath the Jackson-Prospect-Darby Fault in the central part of the belt, and several smaller relatively shallow fields occur in the southern part of the belt. The Rocky Mountain $0 i l$ and Gas Association estimates that over 800 million barrels of oil and nearly five trillion cubic feet of gas occur in the Rare II tracts or parts thereof in the Jackson-Prospect-Darby thrust belt. Significant phosphate resources along with by-product potential in uranium, vanadium, chromium and other critical minerals occur in this belt. DOE, 2 for hydro-border confli.ct.

GEOLOGY: Jackson-Prospect-Darby thrust belt (includes terrain westward to the surface trace of the Absaroka Fault). Surface strata are dominantly Cretaceous through Devonian in age, although locally some Lower Paleozoic rocks are exposed along the Footwall Fault, and some areas are covered by younger Tertiary scdiments.

REFERENCE/CITATION: USFS, 1978, RARE II DES, ID, UT, and WY Suppls.; DOE, 1978, Energy Res. Assessments of RARE II Lands; DOE, 1978, Energy Res. Assessments, of Ten Alternatives-RARE II Lands; Powers, 1977, WGA Gdbk 29; Blackstone, 1978, Tectonic Map of the Overthrust Be1t: WGS; RMOGA, 1978, Estimates of Undiscovered Recoverable Hydrocarbon Resources (RARE-II); White and Williäris, 1975, USGS Circ. 726; NOAA, 1977, Geothermal Energy Resources of the Western U.S.; USGS, 1945, Min. Res. Mo. Valley Region, Pts 1, 2, 3; ERDA, 1976, NURE-Prelim. Rpt.; Armstrong and Oriel, 1965, AAPG Bul1., v. 43; British Sulfur Corp., Ltd., 1964, A world survey of phosphate deposits: Woodalls Ltd. (Printers), London; Gulbrandsen, 1966, Geochim. Cosmochim. Acta, v. 3, 769-778; Brobst and Pratt, 1973, USGS Prof. Paper 820; Worl and Others, 1974, USGS MR-60; Kinkel and Peterson, 1962, USGS MR-13; RMAG, 1972, Geologic Atlas of the Rocky Mountain Region: Denver, CO; Love and Others, 1955, Geologic Map of Wyoming: USGS; Glass and 0thers, 1975, Energy Resources Map of Wyoming: WGS; Sheldon, 1965, USGS Prof. Paper 1313-B; Clabough and others, 1946, USGS Mo. Bas in Studies No. 9; USGS, 1964, MR-42; Chidester and Worthington, 1962, USGS MR-31; Love, 1961, USGS Prof. Paper 424-C; Chidester and Shride, 1962, USGS MR-17. 
ENERGY AND MINERAL RESOURCE EVALUATION - RARE II TRACTS

TRACT N0: 04109

TRACT NAME: North Fork Sheep Creek

ECOREG: 3112

WAR: 20

NATIONAL FOREST: Bridger-Teton

STATE/COUNTY: Wyoming, Lincoln

ACREAGE (GROSS): 20,560 ACREAGE (NET): $20,560100 \mathrm{~N} / \mathrm{G}: 100$ LATITUDE: $42^{\circ} 55^{\prime} \quad$ LONGITUDE: '11042'

INDIVIDUAL TRACT

R.ESOURGE R.ATINGS

ORNL IISFS IDNF

OIL AND GAS

$4 / 3$

$4 \quad 4$

URANIUM

$2 / 1$

4

1

CUÁL

$4 / 4$

4

4

GEOTHERMAL

$2 / 2 \quad 1$

C.RTTICAI. MINFRAL.S

$3 / 2$

4

OVERALL RATING

(WEIGHTED)

3

4

1

NAMES OF CRITICAL MINERALS PRESENT: P?; Ti
Ti-Cretaceous paleoplacers

Stratigraphic and structural traps compounded by thrusting; similar to Canadian Rockies Foothills Belt

COMMENTARY AND SUMMARY: The westward part of the La Barge hydrocarbon complex extends beneath the Jackson-Prospect-Darby Fault in the central part of the belt, and several smaller relatively shallow fields occur in the southern part of the belt. The Rocky Mountain 0il and Gas Association estimates that over 800 million barrels of $0 i 1$ and nearly five trillion cubic feet of gas occur in the Rare II tracts or parts thereof in the Jackson-Prospect-Darby thrust belt. Significant phosphate resources along with by-product potential in uranium, vanadium, chromium and other critical minerals occur in this belt. DOE, 2 for hydro-border conflict.

GEOLOGY: Jackson-Prospect-Darby thrust belt (includes terrain westward to the surface trace of the Absaroka Fault). Surface strata are dominantly Cretaceous through Devonian in age, although locally some Lower Paleozoic rocks are exposed along the Footwall Fault, and some areas are covered by younger Ter liaiy sedineuls.

REFERENCE/CITATION: USFS, 1978, RARE II DES, ID, UT, and WY Suppls.; DOE, 1978, Energy Res. Assessments of RARE II Lands; D0E, 1978, Energy Res. Assessments, of Ten Alternatives-RARE II Lands; Powers, 1977, WGA Gdbk 29; Blackstone, 1978, Tectonic Map of the Overthrust Belt: WGS; RMOGA, 1978, Estimates of Undiscovered Recoverable Hydrocarbon Resources (RARE-II); White and Williams, 1975, USGS Circ. 726; NOAA, 1977, Geothermal Energy Resources of the Western U.S.; USGS, 1945, Min. Res. Mo. Valley Region, Pis 1, 2, 3; ERDA, 1970, NURE-Prel im. Rpt.; Armstrong and Urie1, 1965, AAPG Bull., v. 4j; British Sulfur Corp., Ltd., 1964, A world survey of phosphate deposits: Woodalls Ltd. (Printers), London; Gulbrandsen, 1966, Geochim. Cosmochim. Acta, v. 3, 769-778; Brobst and Pratt, 1973, USGS Prof. Paper 820; Worl and Others, 1974, USGS MR-60; Kinkel and Peterson, 1962, USGS MR-13; RMAG, 1972, Geologic Atlas of the Rocky Mountain Region: Denver, C0; Love and Others, 1955, Geologic Map of Wyoming: USGS; Glass and Others, 1975, Energy Resources Map of Wyoming: WGS; Sheldon, 1965, USGS Prof. Paper 1313-B; Clabough and others, 1946, USGS Mo. Basin Studies No. 9; USGS, 1964, MR-42; Chidester and Worthington, 1962, USGS MR-31; Love, 1961, USGS Prof. Paper 424-C; Chidester and Shride, 1962, USGS MR-17. 


\begin{tabular}{|c|c|c|c|c|}
\hline $\begin{array}{l}\text { INDIVIDUAL TRACT } \\
\text { RESOURCE RATINGS } \\
\end{array}$ & $\underline{\text { ORNL }}$ & $\underline{\text { USFS }}$ & $\underline{\mathrm{DOE}}$ & $\underline{\text { USGS }}$ \\
\hline OIL AND GAS & $4 / 4$ & 4 & 4 & \\
\hline URANIUM & $2 / 3$ & 1 & 1 & \\
\hline COAL & $4 / 3$ & 4 & 3 & \\
\hline GEOTHERMAL & $2 / 2$ & 1 & & \\
\hline CRITICAL MINERALS & $3 / 3$ & 4 & & \\
\hline $\begin{array}{l}\text { OVERALL RATING } \\
\text { (WEIGHTED) }\end{array}$ & $4^{-}$ & & 4 & \\
\hline
\end{tabular}

NAMES OF CRITICAL MINERALS PRESENT: $P(U, V, Z n, F, C d, C r)$

COMMENTARY AND SUMMARY: The westward part of the La Barge hydrocarbon complex extends beneath the Jackson-Prospect-Darby Fault in the central part of the belt, and several smaller relatively shallow fields occur in the southern part of the belt. The Rocky Mountain Oil and Gas Association estimates that over 800 million barrels of oil and nearly five trillion cubic feet of gas occur in the Rare II tracts or parts thereof in the Jackson-Prospect-Darby thrust belt. Significant phosphate resources along with by-product potential in uranium, vanadium, chromium and other critical minerals occur in this belt.

GEOLOGY: Jackson-Prospect-Darby thrust belt (includes terrain westward to the surface trace of the Absaroka Fault). Surface strata are dominantly Cretaceous through Devonian in age, although locally some Lower Paleozoic rocks are exposed along the Footwall Fault, and some areas are covered by younger lertiary sediments.

REFERENCE/CITATION: USFS, 1978, RARE II DES, ID, UT, and WY Suppls.; DOE, 1978, Energy Res. Assessments of RARE II Lands; DOE, 1978, Energy Res. Assessments, of Ten Alternatives-RARE II Lands; Powers, 1977, WGA Gdbk 29; Blackstone, 1978, Tectonic Map of the Overthrust Belt: WGS; RMOGA, 1978, Estimates of Undiscovered Recoverable Hydrocarbon Resources (RARE-II); White and Williams, 1975, USGS Circ. 726; NOAA, 1977, Geothermal Energy Resources of the Western U.S.; USGS, 1945, Min. Res. Mo. Valley Region, Pts 1, 2, 3; ERDA, 1976, NURE-Prelim. Rpt.; Armstrong and Orie1, 1965, AAPG Bull., v. 43; British Sulfur Corp., Ltd., 1964, A world survey of phosphate deposits: Woodalls Ltd. (Printers), London; Gulbrandsen, 1966, Geochim. Cosmochim. Acta, v. 3, 769-778; Brobst and Pratt, 1973, USGS Prof. Paper 820; Worl and 0thers, 1974, USGS MR-60; Kinke1 and Peterson, 1962, USGS MR-13; RMAG, 1972, Geologic Atlas of the Rocky Mountain Region: Uenver, CU; Love and Uthers, 1955, Geologic Map of Wyoming: USGS; Glass and Others, 1975, Energy Resources Map of Wyoming: WGS; Sheldon, 1965, USGS Prof. Paper 1313-B; Clabough and others, 1946, USGS Mo. Basin Studies No. 9; USGS, 1964, MR-42; Chidester and Worthington, 1962, USGS MR-31; Love, 1961, USGS Prof. Paper 424-C; Chidester and Shride, 1962, USGS MR-17. 
ENERGY AND MINERAL RESOURCE EVALUATION - RARE II TRACTS

TRACT NO: 04111

TRACT NAME: Gannett Spring Creek

ECOREG: 3112

WAR: 18

NATIONAL FOREST: Bridger-Teton/Caribou

STATE/COUNTY: Wyoming/Idaho, Lincoln/Caribou/Lake

ACREAGE (GROSS): 66,900 ACREAGE (NET): $66,020100 \mathrm{~N} / \mathrm{G}: 99$ LATITUDE: $42^{\circ} 33^{\prime}$ LONGITUDE: $111^{\circ} 00^{\prime}$

\begin{tabular}{|c|c|c|c|}
\hline $\begin{array}{l}\text { INDIVIDUAL TRACT } \\
\text { RESOURCE RATINGS } \\
\end{array}$ & ORNL & USFS & DOE \\
\hline OIL AND GAS & $4 / 3$ & 4 & 4 \\
\hline URANIUM & $2 / 1$ & 1 & 1 \\
\hline C.OÁL & $4 / 3$ & 4 & 3 \\
\hline GEOTHERMAL & $3 / 2$ & 1 & \\
\hline CRITIC.AI. MINERAI..S & $2 / 1$ & 1 & \\
\hline $\begin{array}{l}\text { OVERALL RATING } \\
\text { (WEIGHTED) }\end{array}$ & $3^{+}$ & & 4 \\
\hline
\end{tabular}

NAMES OF CRITICAL MINERALS PRESENT:

COMMENTARY AND SUMMARY: Several major and several lesser oil and/or gas fields are loçated in the southern part of the Absaroka Belt in Wyoming and Utah. Most production is from Jurassic-Triassic reservoirs, but more recent deeper discoveries are in Upper Paleozoic rocks (Phosphoria) and even more recently in Lower Paleozoic rocks. The Rocky Mountain 0il and Gas Association estimates that Rare II tracts in the Absaroka belt contain nearly 3.3 billion barrels of oil and over 12.5 trillion cubic feet of gas. The major part of the Southeast Idaho phosphate resource is in this thrust belt, with mur.h of it in the Rare II tracts. Not only are the phosphate rock resources impurtant for the phosphorus, but there is a significant near-future potential for vanadium, uranium by-product production. The Mt. Pisgah gold district in Bonneville County may have significant potential for Carlin-type gold deposits (Rare II tracts:04160, 04161, and 04162). DOE, moderate corridor R-45 conflict.

GEOLOGY: Absaroka thrust belt (includes terrain westward to surface trace of the Paris-Bannock thrust complex). Includes (as secondary structures) the Crawford, Meade, Medicine Lodge, Sheep Mountain, Skyline, and many smaller thrust faults. Rocks exposed at the surface include sedimentary rocks from Cambrian to Tertiary in age along with some Tertiary and Quaternary volcanics. Several small igneous intrusions of Tertiary Age have been mapped in the Idaho part of the Absaroka Belt, chiefly in the vicinity of the Mt. Pisgah gold district.

REFERENCE/CITATION: USFS, 1978, RARE II DES, ID, UT, and WY Suppls.; DOF, 1978, Energy Res. Assessments of RARE II Lands; DOE, 1978, Energy Res. Assessments, of Ten Alternatives-RARE II Lands; Powers, 1977, WGA Gdbk 29; Blackstone, 1978, Tectonic Map of the Overthrust Belt: WGS; RMOGA, 1978, Estimates of Undiscovered Recoverable Hydrocarbon Resources (RARE-II); White and Williams, 1975, USGS Circ. 726; NOAA, 1977, Geothermal Energy Resources of the Western U.S.; USGS, 1945, Min. Res. Mo. Valley Region, Pts 1, 2, 3; ERDA, 1976, NURE-Prelim. Rpt.; Armstrong and Oriel, 1965, AAPG Bull., v. 43; British Sulfur Corp., Ltd., 1964, A world survey of phosphate deposits: Woodalls Ltd. (Printers), London: liulbrandsen, 1966, Geochim. Cosmochim. Acta, v. 3,.769-778; Brobst and Pratt, 1973, USGS Prof. Paper 820; Worl and Others, 1974, USGS MR-60; Kinkel and Peterson, 1962, USGS MR-13; RMAG, 1972, Geologic Atlas of the Rocky Mountain Region: Denver, CO; Love and Others, 1955, Geologic Map of Wyoming: USGS; Glass and Others, 1975, Energy Resources Map of Wyoming: WGS; Sheldon, 1965, USGS Prof. Paper 1313-B; Clabough and others, 1946, USGS Mo. Bas in Studies No. 9; USGS, 1964, MR-42; Chidester and Worthington, 1962, USGS MR-31; Love, 1961, USGS Prof. Paper 424-C; Chidester and Shride, 1962, USGS MR-17. 
ENERGY AND MINERAL RESOURCE EVALUATION - RARE II TRACTS

TRACT NO: 04112

TRACT NAME: Commissary Range

ECOREG: 3112

WAR: 21

NATIONAL FOREST: Bridger-Teton

STATE/COUNTY: Wyoming, Lincoln

ACREAGE (GROSS): 179,920 ACREAGE (NET): $178,180100 \mathrm{~N} / \mathrm{G}: 99$ LATITUDE: $42^{\circ} 20^{\prime}$ LONGITUDE: $110^{\circ} 45^{\prime}$

INDIVIDUAL TRACT RESOURCE RATINGS

\begin{tabular}{|c|c|c|c|}
\hline RESOURCE RATINGS & ORNL & USFS & $\underline{D O E}$ \\
\hline OIL AND GAS & $4 / 3$ & 4 & 4 \\
\hline URANIUM & $3 / 2$ & 1 & 1 \\
\hline COAL & $4 / 3$ & 4 & 3 \\
\hline GEOTHERMAL & $2 / 2$ & 1 & \\
\hline CRITICAL MINERALS & $4 / 4$ & 4 & \\
\hline $\begin{array}{l}\text { OVERALL RATING } \\
\text { (WEIGHTED) }\end{array}$ & $4^{+}$ & & 4 \\
\hline
\end{tabular}

REMARKS

Stratigraphic and structural traps compounded by thrusting; similar to Canadian Rockies Foothills Belt

NAMES OF CRITICAL MINERALS PRESENT: $P(U, V, F, \mathrm{Zn}, \mathrm{Cd}, \mathrm{Cr}$ ); Mo

COMMENTARY AND SUMMARY: Several major and several lesser oil and/or gas fields are located in the southern part of the Absaroka Belt in Wyoming and Utah. Most production is from Jurassic-Triassic reservoirs, but more recent deeper discoveries are in Upper. Paleozoic rocks (Phosphoria) and even more recently in Lower Paleozoic rocks. The Rocky Mountain 0 il and Gas Association estimates that Rare II tracts in the Absaroka belt contain nearly 3.3 billion barrels of oil and over 12.5 trillion cubic feet of gas. The major part of the Southeast Idaho phosphate resource is in this thrust belt, with much of $i t$ in the Rare II tracts. Not only are the phosphate rock resources important for the phosphorus, but there is a significant near-future potential for vanadium, uranium by-product production. The Mt. Pisgah gold district in Bonneville County may have significant potential for Carlin-type gold deposits (Rare II tracts 04160, 04161, and 04162).

GEOLOGY: Absaroka thrust belt (includes terrain westward to surface trace of the Paris-Bannock thrust complex). Includes (as secondary structures) the Crawford, Meade, Medicine Lodge, Sheep Mountain, Skyline, and many smaller thrust faults. Rocks exposed at the surface include sedimentary rocks from Cambrian to Tertiary in age along with some Tertiary and Quaternary volcanics. Several small igneous intrusions of Tertiary Age have been mapped in the Idaho part of the Absaroka Belt, chiefly in the vicinity of the Mt. Pisgah gold district.

REFERENCE/CITATION: USFS, 1978, RARE II DES, ID, UT, and WY Suppls.; DOE, 1978, Energy Res. Assessments of RARE II Lands; DOE, 1978, Energy Res. Assessments, of Ten Alternatives-RARE II Lands; Powers, 1977, WGA Gdbk 29; Blackstone, 1978, Tectonic Map of the Overthrust Belt: WGS; RMOGA, 1978, Estimates of Undiscovered Recoverable Hydrocarbon Resources (RARE-II); White and Williams, 1975, USGS Circ. 726; NOAA, $197 \%$, Geothermal Energy Resources of the Western U.S.; USGS, 1945, Min. Res. Mo. Valley Region, Pts 1, 2, 3; ERDA, 1976, NURE-Prelim. Rpt.; Armstrong and Oriel, 1965, AAPG Bull., v. 43; British Sulfur Corp., Ltd., 1964, A world survey of phosphate deposits: Woodal1s Ltd. (Printers), London; Gulbrandsen, 1966, Geochim. Cosmochim. Acta, v. 3, 769-778; Brobst and Pratt, 1973, USGS Prof. Faper 820; Worl and Others, 1974, USGS MR-60; Kinkel and Peterson, 1962, USGS MR-13; RMAG, 1972, Geologic Atlas of the Rocky Mountain Region: Denver, C0; Love and Others, 1955, Geologic Map of Wyoming: USGS; Glass and Others, 1975, Energy Resources Map of Wyoming: WGS; Sheldon, 1965, USGS Prof. Paper 1.313-B; Clabough and others, 1946, USGS Mo. Basin Studies No. 9; USGS, 1964, MR-42; Chidester and Worthington, 1962, USGS MR-31; Love, 1961, USGS Prof. Paper 424-C; Chidester and Shride, 1962, USCS MR-17. 
ENERGY AND MINERAL RESOURCE EVALUATION - RARE II TRACTS

TRACT N0: 04113

TRACT NAME: Nuggent Park West

ECOREG: 3112

WAR: 16

NATIONAL FOREST: Bidger-Teton

STATE/COUNTY: Wyoming, Lincoln

ACREAGE (GROSS): 7,640 ACREAGE (NET): $7,640 \quad 100 \mathrm{~N} / \mathrm{G}: 100$ LATITUDE: $42^{\circ} 14^{\prime}$ LONGITUDE: $110^{\circ} 49^{\prime}$

INDIVIDUAL TRACT

RESOURCE RATINGS

$\underline{\text { ORNL }} \underline{\text { USFS }} \quad \underline{\text { DOE }} \quad \underline{\text { USGS }}$

OIL AND GAS

$4 / 3$

4

4

URAN IUM

$2 / 1$

1

COAL

$1 / 3$

4

1

GEOTHERMAL

$2 / 2$

1

CRITICAL MINERALS

$2 / 1$

1

OVERALL RATING

(WEIGHTED)

$3^{+}$

1

NAMES OF CRITICAL MINERALS PRESENT:

COMMENTARY AND SUMMARY: Several major and several lesser oil and/or gas fields are located in the southern part of the Absaroka Belt in Wyoming and Utah. Most production is trom Jurassic-Iriassic reservoirs, but more recent deeper discoveries are in Upper Paleozoic rocks (Phosphoria) and even more recently in Lower Paleozoic rocks. The Rocky Mountain 011 and Gas Association estimates that Rare II tracts in the Absaroka belt contain nearly 3.3 billion barrels of oil and over 12.5 trillion cubic feet of gas. The major part of the Southeast Idaho phosphate resource is in this thrust belt, with much of it in the Rare II tracts, Not only are the phosphate rock resources important for the phosphorus, but there is a signiticant near-tuture potential for vanadium, uranium by-product production. Ihe Mt. Pisgah gold district in Bonneville County may have significant potential for Carlin-type gold deposits (Rare II tracts 04160, 04161, and 04162).

GEOLOGY: Absaroka thrust belt (includes terrain westward to surface trace of the Paris-Bannock thrust complex). Includes (as secondary structures) the Crawford, Meade, Medicine Lodge, Sheep Mountain, Skyline, and many smaller thrust faults. Rocks exposed at the surface include sedimentary rocks from Cambrian to Tertiary in age along with some Tertiary and Quaternary volcanics. Several small igneous intrusions of Tertiary Age have been mapped in the Idaho part of the Absaroka Belt, chiefly in the vicinity of the Mt. Pisgah gold district.

REFERENCE/CITATION: USFS, 1978, RARE II DES, ID, UT, and WY Suppls.; DOE, 1978, Energy Res. Assessments of RARE II Lands; DOE, 1978, Energy Res. Assessments, of Ten Alternatives-RARE II Lands; Powers, 1977, WGA Gdbk 29; Blackstone, 1978, Tectonic Map of the Overthrust Belt: WGS; RMOGA, 1978, Estimates of Undiscovered Recoverable Hydrocarbon Resources (RARE-II); White and Williams, 1975, USGS Circ. 726; NOAA, 1977, Geothermal Energy Resources of the Western U.S.; USGS, 1945, Min. Res. Mo. Valley Region, Pts 1, 2, 3; ERDA, 1976, NURE-Prelim. Rpt.; Armstrong and Oriel, 1965, AAPG Bul1., v. 43; British Sulfur Corp., Ltd., 1964, A world survey of phosphate deposits: Woodalis Ltd. (Printers), London; Gulbrandsen, 1966, Geochim. Cosmochim. Acta, v. 3, 769-778; Brobst and Pratt, 1973, USliS Prof. Paper 820; Worl and Others, 1974, USGS MR-60; Kinkel and Peterson, 1962, USGS MR-13; RMAG, 1972, Geologic Atlas of the Rocky Mountain Region: Denver, CO; Love and 0thers, 1955, Geologic Map of Wyoming: USGS; Glass and Others, 1975, Energy Resources Map of Wyoming: WGS; Sheldon, 1965, USGS Prof. Paper 1313-B; Clabough and others, 1946, USGS Mo. Basin Studies No. 9; USGS, 1964, MR-42; Chidester and Worthington, 1962, USGS MR-31; Love, 1961, USGS Prof. Paper 424-C; Chidester and Shride, 1962, USGS MR-17. 
ENERGY AND MINERAL RESOURCE EVALUATION - RARE II TRACTS

TRACT NO: 04114

TRACT NAME: Hams Fork Ridge

ECOREG : 3112

WAR: 19

NATIONAL FOREST: Bidger-Teton

ACREAGE (GROSS): 13,950 ACREAGE (NET): $13,870100 \mathrm{~N} / \mathrm{G}: 99$ LATITUDE: $42^{\circ} 12^{\prime}$ LONGITUDE: $110^{\circ} 45^{\prime}$

STATE/COUNTY: Wyoming, Lincoln
INDIVIDUAL TRACT

RESOURCE RATINGS

OIL AND GAS

URANIUM

COAL

GEOTHERMAL

CRITICAL MINERALS

OVERALL RATING

(WEIGHTED)

$\frac{\text { ORNL }}{4 / 4} \quad \frac{\text { USFS }}{4} \quad \frac{\text { DOE }}{4} \quad \underline{\text { USGS }}$

$4 / 1$

$2 / 2$

$4 / 4$

4
REMARKS

Stratigraphic and structural traps compounded by thrusting; similar to Canadian Rockies Foothills Belt

NAMES OF CRITICAL MINERALS PRESENT: $P(U, V, F, \mathrm{Zn}, \mathrm{Cd}, \mathrm{Cr})$

COMMENTARY AND SUMMARY: Several major and several lesser oil and/or gas fields are located in the southern part of the Absaroka Belt in Wyoming and Utah. Most production is from Jurassic-Triassic reservoirs, but more recent deeper discoveries are in Upper Paleozoic rocks (Phosphoria) and even more recently in Lower Paleozoic rocks. The Rocky Mountain $0 i 1$ and Gas Association estimates that Rare II tracts in the Absaroka belt contain nearly 3.3 billion barrels of oil and over 12.5 trillion cubic feet of gas. The major part of the Southeast Idaho phosphate resource is in this thrust belt, with much of it in the Rare II tracts. Not only are the phosphate rock resources important for the phosphorus, but there is a significant near-future potential for vanadium, uranium by-product production. The Mt. Pisgah gold district in Bonneville County may have significant potential for Carlin-type gold deposits (Rare II tracts 04160, 04161, and 04162).

GEOLOGY: Absaroka thrust belt (includes terrain westward to surface trace of the Paris-Bannock thrust complex). Includes (as secondary structures) the Crawford, Meade, Medicine Lodge, Sheep Mountain, Skyline, and many silialler thrust faults. Rocks exposed at the surface include sedimentary rocks from Cambrian to Tertiary in age along with some Tertiary and Quaternary volcanics. Several small igneous intrusions of Tertiary Age have been mapped in the Idaho part of the Absaroka Belt, chiefly in the vicinity of the Mt. Pisgah gold district.

REFERENCE/CITATION: USFS, 1978, RARE II DES, ID, UT, and WY Supp1s.; DOE, 1978, Energy Res. Assessments of RARE II Lands; DOE, 1978, Energy Res. Assessments, of Ten Alternatives-RARE II Lands; Powers, 1977 , WGA Gdbk 29; B1ackstone, 1978, Tectonic Map of the Overthrust Belt: WGS; RMOGA, 1978, Estimates of Undiscuvered Recoverable Hydrocarbon Resources (RARE-II); White and Williams, 1975, USGS Circ. 726 ; NOAA, 1977, Geothermal Energy Resources of the Western U.S.; USGS, 1945, Min. Res. Mo. Valley Region, Pts i, 2, 3; ERDA, 1976, NURE-Prelim. Rpt.; Armstrong and Óriel, 1965, AAPG Bull., v. 43; British Sulfur Corp., Ltd., 1964, A world survey of phosphate deposits: Woodalls Ltd. (Printers), London; Gulbrandsen, 1966, Geochim. Cosmochim. Acta, v. 3, 769-778; Brobst and Pratt, 1973, USGS Prof. Paper 820; Worl and Others, 1974, USGS MR-60; Kinkel and Peterson, 1962, USGS MR-13; RMAG, 1972, Geologic Atlas of the Rocky Mountain Region: Denver, CO; Love and 0thers, 1955, Geologic Map of Wyoming: USGS; Glass and 0thers, 1975, Energy Resources Map of Wyoming: WGS; Sheldon, 1965, USGS Prof. Paper 1313-B; Clabough and others, 1946, USGS Mo. Basin Studies No. 9; USGS, 1964, MR-42; Chidester and Worthington, 1962, USGS MR-31; Love, 1961, USGS Prof. Paper 424-C; Chidester and Shride, 1962, USGS MR-17. 
NATIONAL FOREST: Bidger-Teton

ACREAGE (GROSS): 5,290 ACREAGE (NET): 5,290
STATE/COUNTY: Wyoming, Teton/Sublette

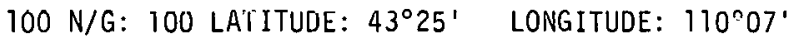

\begin{tabular}{|c|c|c|c|c|}
\hline $\begin{array}{l}\text { INDIVIDUAL TRACT } \\
\text { RESOURCE RATINGS }\end{array}$ & $\underline{\text { ORNL }}$ & USFS & $\underline{D O E}$ & USGS \\
\hline OIL AND GAS & $4 / 4$ & 1 & 3 & \\
\hline URANIUM & $2 / 1$ & 1 & 1 & \\
\hline GOAL & $2 / 1$ & 1 & NF & \\
\hline GEOTHERMAL & $2 / 2$ & 1 & & \\
\hline CRITICAL MINERALS & $1 / 3$ & 1 & & \\
\hline $\begin{array}{l}\text { OVERALL RATING } \\
\text { (WEIGHTED) }\end{array}$ & $3^{-}$ & & 3 & \\
\hline
\end{tabular}

REMARKS

Stratigraphic and structural traps compounded by thrusting; similar to Canadian Rockies Foothills Belt

NAMES OF CRITICAL MINERALS PRESENT:

COMMENTARY AND SUMMARY: Part of the large La Barge hydrocarbon complex with the associated Greater Big Piney Gas Area is located in the centrál part of the Footwall Bell. Numleruus sillalle, oil and/or gas fields also occur along nearly the entire length of the belt and include a recent major gas discovery in Teton County in a roaded salient extending deep into Rare II tract 4102. Over 200 million barrels of 0 il and nearly 15 trillion cubic feet of gas have been estimated by the Rocky Mountain $0 i 1$ and Gas Association for Rare II tracts in this belt. The Permian Phosphoria Formation contains part of the region's large phosphate resources.

GEOLOGY: Footwall Belt of the Jackson-Prospect-Darby fault system (extends eastward to the crest of the Moxa Arch and its northward projection). Surface rocks are largely Tertiary in age, except in the north where the Gros Ventre, West Slope of the Tetons, and several smaller satellite Rare II tracts contain the entire regional stratigraphic sequence from Precambrian through Cenzolc.

REFERENCE/CITATION: USFS, 1978, RARE II DES, ID, UT, and WY Suppls.; D0E, 1978, Energy Res. Assessments of RARE II Lands; DOEE, 1978, Energy kes. Assessments, of Ten Alternatlves-RARE II Lallds, Füwei's, 1977 , WGA Gdbk 29; Blackstone, 1978, Tectonic Map of the Overthrust Belt: WGS; RMOGA, 1978, Estimates of Undiscovered Recoverable Hydrocarbon Resources (RARE-II); White and Williams, 1975, USGS Circ. 726; NOAA, 1977, Geothermal Energy Resources of the Western U.S.; USGS, 1945, Min. Res. Mo. Valley Region, Pts 1,?, 3; ERDA, 1976, NURE-Prelim. Rpt.; Armstrong and Oriel, 1965, AAPG Bull., v. 43; British Sulfur Corp., Ltd., 1964, A world survey of phosphate deposits: Woodalls Ltd. (Printers), London; Gulbrandsen, 1966, Geochim. Cosmochim. Acta, v. 3, 769-778; Brobst and Pratt, 1973, USGS Prof. Paper 820; Worl and 0thers, 1974, USGS MR-60; Kinkel and Peterson, 1962, USGS MR-13; RMAG, 1972, Geologic Atlas of the Rocky Mountain Region: Denver, C0; Love and Others, 1955, Geologic Map of Wyoming: USGS; Glass and Others, 1975, Energy Resources Map of Wyoming: WGS; Sheldon, 1965, USGS Prof. Paper 1313-B; Clabough and others, 1946, USGS Mo. Bas in Studies No. 9; USGS, 1964, MR-42; Chidester and Worthington, 1962, USGS MR-31; Love; 1961, USGS Prot. Haper 424-C; Chidester and Shride, 1962, USGS MR=17. 
ENERGY AND MINERAL RESOURCE EVALUATION - RARE II TRACTS

TRACT NO: 04116

TRACT NAME: Gypsum Creek -

ECOREG: 3112

WAR: 15

NATIONAL FOREST: Bridger-Teton

STATE/COUNTY: Wyoming, Sublette

ACREAGE (GROSS): 17,300 ACREAGE (NET): $17,300100 \mathrm{~N} / \mathrm{G}: 100$ LATITUDE: $43^{\circ} 19^{\prime}$ LONGITUDE: $109^{\circ} 59^{\prime}$

INDIVIDUAL TRACT

RESOURCE RATINGS

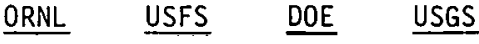

OIL AND GAS

$4 / 3$

3

URANIUM

$3 / 1$

1

2

COAL

$2 / 1$

1

1

GEOTHERMAL

$3 / 2 \quad 1$

CRITICAL MINERALS $3 / 2$

OVERALL RATING

(WEIGHTED)

$2^{+}$

NAMES OF CRITICAL MINERALS PRESENT: $P(U, V, F, Z n, C d, C r)$

COMMENTARY AND SUMMARY: Part of the large La Barge hydrocarbon complex with the associated Greater Big Piney Gas Area is located in the central part of the Footwall Belt. Numerous smaller oil and/or gas fields also occur along nearly the entire length of the belt and include a recent major gas discovery in Teton County in a roaded salient extending deep into Rare Il tract 4102 . Over 200 mil1ion barrels of 0 il and nearly 15 trillion cubic feet of gas have been estimated by the Rocky Mountain 0 il and Gas Association for Rare II tracts in this belt. The Permian Phosphoria Formation contains part of the region's large phosphate resources.

GEOLOGY: Footwall Belt of the Jackson-Prospect-Darby fault system (extends eastward to the crest of the Moxa Arch and its northward projection). Surface rocks are largely Tertiary in age, except in the north where the Gros Ventre, West Slope of the Tetons, and several smaller satellite Rare II tracts contain the entire regional stratigraphic sequence from Precambrian through Cenzoic.

REFERENCE/CITATION: USFS, 1978, RARE II DES, ID, UT, and WY Supp1s.; D0E, 1978, Energy Res. Assessments of RARE II Lands; DOE, 1978, Energy Res. Assessments, of Ten Alternatives-RARE II Lands; Powers, 1977, WGA Gdbk 29; Blackstone, 1978, Tectonic Map of the Overthrust Belt: WGS; RMOGA, 1978, Estimates of Undiscovered Recoverable Hydrocarbon Resources (RARE-II); White and Williams, 1975, USGS Circ. 726; NOAA, 1977, Geothermal Energy Resources of the Western U.S.; USGS, 1945, Min. Res. Mo. Valley Region, Pts 1, 2, 3; ERDA, 1976, NURE-Prelim. Rpt.; Armstrong and Oriel, 1965, AAPG Bull., v. 43; British Sulfur Corp., Ltd., 1964, A world survey of phosphate deposits: Woodalls Ltd. (Printers), London; Gulbrandsen, 1966, Geochim. Cosmochim. Acta, v. 3, 769-778; Brobst and Pratt, 1973, USGS Prof. Paper 820; Worl and Others, 1974, USGS MR-60; Kinkel and Peterson, 1962, USGS MR-13; RMAG, 1972, Geologic Atlas of the Rocky Mountain Region: Denver, CO; Love and Others, 1955, Geologic Map of Wyoming: USGS; Glass and Others, 1975, Energy Resources Map of Wyoming: WGS; Sheldon, 1965, USGS Prof. Paper 1313-B; Clabough and others, 1946, USGS Mo. Basin Studies No. 9; USGS, 1964, MR-42; Chidester and Worthington, 1962, USGS MR-31; Love, 1961, USGS Prof. Paper 424-C; Chidester and Shride, 1962, USGS MR-17. 
ENERGY AND MINERAL RESOURCE EVALUATION - RARE II TRACTS

TRACT NO: 04151

TRACT NAME: West Mink

ECOREG: 3130

WAR: 16

NATIONAL FOREST: Caribou

STATE/COUNTY: Idaho, Bannock

ACREAGE (GROSS): 21,100 ACREAGE (NET): $20,280^{\circ} 100 \mathrm{~N} / \mathrm{G}: 96$ LATITUDE: $42^{\circ} 46^{\prime}$ LONGITUDE: $112^{\circ} 27^{\prime}$

INDIVIDUAL TRACT

RESOURCE RATINGS

$\underline{\text { ORNL }} \underline{\text { USFS }} \underline{\text { DOE }} \underline{\text { USGS }}$

OIL AND GAS

$4 / 1 \quad 1 \quad \cdot 2$

2

IIRON IIIM

2.1

1

COAL

$\begin{array}{lll}1 / 4 & 1\end{array}$

GEOTHERMAL

$2 / 2 \quad 1$

CRITICAL MINERALS

$2 / 2 \quad 1$

OVERALL RATING

(WEIGHTED)

$1^{+}$

2

NAMES OF CRITICAL MINERALS PRESENT: Base and precious metals?

COMMENTARY AND SUMMARY: Petroleum exploration has not been as intensive in the Paris-Bannock thrust belt as in the more easterly thrust structures; however, several holes showing some oil and gas have been completed in the past. The Rocky Mountain $0 i l$ and Gas Association estimates that over 300 million barrels of oil and approximately three trillion cubic feet of gas occur in Rare II tracts in this belt. Phosphate resources are minor in comparison with the more easterly belts. Some potential for disseminated gold and base metals in the Precambrian and Lower Paleozoic strata is also present.

GEOLOGY: Paris-Bannock thrust belt (includes terrain between Paris-Bannock fault on east and the Wasatch fault and its northward projection on the west). The Wasatch fault is the major east boundary fault of the Basin and Range structural province and is generally normal in character, usually having a steep westward dip. Bedrock includes strata from the younger Precambrian, all Paleozoic systems, and Tertiary and Quaternary deposits. Tertiary and Quaternary volcanic rocks and similar age gravels locally cover the older rocks and structures.

REFERENCE/CITATION: USFS, 1978, RARE II DES, ID, UT, and WY Suppls.; DOE, 1978, Energy Res. Assessments of RARE II Lands; DOE, 1978, Energy Res. Assessments, of Ten Aiternatives-RARE II Lands; Powers, 1977 , WGA Gdbk 29; Blackstone, 1978, Tectonic map of the Overthrust Be1t: WGS; RMOGA, 1978, Estimates of Undiscovered Recoverable Hydrocarbon Resources (RARE-II); White and Williams, 1975, USGS Circ. 726; NOAA, 1977, Geothermal Energy Resources of the Western U.S.; USGS, 1945, Min. Res. Mo. Valley Region, Pts. 1.2.3: ERDA, 1976, NURE-Prelim. Rpt.; Armetrong and Oriol, 1965, AAPG Bu11., v. 43; Rritich Sulfur Corp., Ltd., 1964, A World Survey of Phosphate Deposits: Woodails Ltd. (Printers), London; Gulbrandsen, 1966, Geochim. Cosmochim. Acta, v. 3, p. 769-778; Brobst and Pratt, 1973, USGS Prof. Paper 820; Worl and Others, 1974, USGS MR-60; Kinkel and Peterson, 1962, USGS MR-13; RMAG, 1972, Geologic Atlas of the Rocky Mounta in Region: Denver, C0; Bond and Others, 1978, Geologic Map of Idaho: IBMG; Ross, C.P., 1941, IBMG Pamph. 57, pt. 111; Mansfie1d, 1927, USGS Prof. Paper 152; Leonard and 0thers, 1978, USGS OFR 78-360; USGS, 1964, Mineral and Water Resources of Idaho: 88th U.S. Congress; Vine, 1959, USGS Bull. IOSb-l. 
INDIVIDUAL TRACT RESOURCE RATINGS

OIL AND GAS ORN $\underline{\text { USFS }}$ $\underline{D O E}$ 2

URANIUM

COAL

GEOTHERMAL

CRITICAL MINERALS

OVERALL RATING (WEIGHTED)

$\begin{array}{cccc}\frac{1}{4 / 1} & 1 & 2 & \text { DOE } \\ 2 / 1 & 1 & 1 \\ 1 / 4 & 1 & 1 \\ 2 / 2 & 1 & \\ 2 / 2 & 1 & \\ 1+ & & 2\end{array}$

\author{
REMARKS \\ Stratigraphic and structural traps com- \\ pounded by thrusting; similar to Canadian \\ Rockies Foothills Belt
}

NAMES OF CRITICAL MINERALS PRESENT: Base and precious metals?

COMMENTARY AND SUMMARY: Petroleum exploration has not been as intensive in the Paris-Bannock thrust belt as in the more easterly thrust structures; however, several holes showing some oil and gas have been completed in the past. The Rocky Mountain $0 i 1$ and Gas Association estimates that over 300 million barrels of oil and approximately three trillion cubic feet of gas occur in Rare II tracts in this belt. Phosphate resources are minor in comparison with the more easterly belts. Some potential for disseminated gold and base metals in the Precambrian and Lower Paleozoic strata is also present.

GEOLOGY: Paris-Bannock thrust belt (includes terrain between Paris-Bannock fault on east and the Wasatch fault and its northward projection on the west). The Wasatch fault is the major east boundary fault of the Basin and Range structural province and is generally normal in character, usually having a steep westward dip. Bedrock includes strata from the younger Precambrian, all Paleozoic systems, and Tertiary and Quaternary deposits. Tertiary and Quaternary volcanic rocks and similar age gravels locally cover the older rocks and structures.

REFERENCE/CITATION: USFS, 1978, RARE II DES, ID, UT, and WY Suppls.; DOE, 1978, Energy Res. Assessments of RARE II Lands; DOE, 1978, Energy Res. Assessments, of Ten Alternatives-RARE II Lands; Powers, 1977, WGA Gdbk 29; Blackstone, 1978, Tectonic map of the Overthrust Belt: WGS; RMOGA, 1978, Estimates of Undiscovered Recoverable Hydrocarbon Resources (RARE-II); White and Williams, 1.975, USGS Circ. 726; NOAA, 1977, Geothermal Energy Resources of the Western U.S.; USGS, 1945, Min. Res. Mo. Valley Region, Pts. 1,2,3; ERDA, 1976, NURE-Prel im. Rpt.; Armstrong and Oriel, 1965, AAPG Bul1., v. 43; British Sulfur Corp., Ltd., 1964, A World Survey of Phosphate Deposits: Woodalls Ltd. (Printers), London; Gulbrandsen, 1966, Geochim. Cosmochim. Acta, v. 3, p. 769-778; Brobst and Pratt, 1973, USGS Prof. Paper 820; Worl and Others, 1974, USGS MR-60; Kinkel and Peterson, 1962, USGS MR-13; RMAG, 1972, Geologic Atlas of the Rocky Mounta in Region: Denver, CO; Bond and Others, 1978, Geologic Map of Idaho: IBMG; Ross, C.P., 1941, IBMG Pamph. 57, pt. 111; Mansfield, 1927, USGS Prof. Paper 152; Leonard and 0thers, 1978, USGS OFR 78-360; USGS, 1964, Mineral and Water Resources of Idaho: 88th U.S. Congress; Vine, 1959, USGS Bul1. 1055-1. 
ENERGY AND MINERAL. RESOURCE EVALUATION - RARE II TRACTS

TRACT NO: 04153

NATIONAL FOREST: Caribou
TRACT NAME: Toponce

ECOREG: 3112

WAR: 18

STATE/COUNTY: Idaho, Caribou/Bannock

\begin{tabular}{|c|c|c|c|c|}
\hline $\begin{array}{l}\text { INDIVIDUAL TRACT } \\
\text { RESOURCE RATINGS } \\
\end{array}$ & $\underline{\text { ORNL }}$ & $\underline{\text { USFS }}$ & $\underline{D O E}$ & USGS \\
\hline OIL AND GAS & $4 / 1$ & 4 & 3 & \\
\hline UP.AN IUM & $2 / 1$ & 1 & 1 & \\
\hline COAL & $1 / 4$ & 1 & 1 & \\
\hline GEOTHERMAL & $2 / 2$ & 1 & & \\
\hline CRITICAL MINERALS & $2 / 2$ & 1 & & \\
\hline $\begin{array}{l}\text { OVERALL RATING } \\
\text { (WEIGHTED) }\end{array}$ & $1^{+}$ & & 3 & \\
\hline
\end{tabular}

REMARKS

Stratigraphic and structural traps compounded by thrusting; similar to Canadian Rockies Foothills Belt

NAMES OF CRITICAL MINERALS PRESENT: Base and precious metals?

COMMENTARY AND SUMMARY: Petroleum exploration has not been as intensive in the Paris-Bannock thrust belt as in the more easterly thrust structures; however, several holes showing some oil and gas have been completed in the past. The Rocky Mountain $0 i l$ and Gas Association estimates that over 300 million barrels of oil and approximately three trillion cubic feet of gas occur in Rare II tracts in this belt. Phosphate resources are minor in comparison with the more easterly belts. Some potential for disseminated gold and base metals in the Precambrian and Lower Paleozoic strata is also present. DOE, low corridor R-49 conflict.

GEOLOGY: Paris-Bannock thrust belt (includes terrain between Paris-Bannock fault on east and the Wasatch fault and its northward projection on the west). The Wasatch fault is the major east boundary fault of the Basin and Range structural province and is generally normal in character, usually having a steep westward dip. Bedrock includes strata from the younger Precambrian, all Paleozoic systems, and Tertiary and Quaternary deposits. Tertiary and Quaternary volcanic rocks and similar age gravels locally cover the older rocks and structures.

REFERENCE/CITÁTION: USFS, 1978, RARE İI DES, ID, UT, and WY Suppls.; DOE, 1978, Energy Res. Assessments of RARE II Lands; DOE, 1978, Energy Res. Assessments, of Ten Alternatives-RARE II Lands; Powers, 1977, WGA Gdbk 29; Blackstone, 1978, Tectonic map of the Overthrust Belt: WGS; RMOGA, 1978, Estimates of Undiscovered Recoverable Hydrocarbon Resources (RARE-II); White and Williams, 1975, USGS Circ. 726; NOAA, 1977, Geothermal Energy Resources of the Western U.S.; USGS, 1945, Min. Res. Mo. Valley Region, Pts. 1,2,3; ERDA, 1976, NURE-Prelim. Rpt.; Armstrong and Oriel, 1965, AAPG Bul1., v. 43; British Sulfur Corp., Ltd., 1964, A World Survey of Phosphate Deposits: Woodalls Ltd. (Printers), London; Gulbrandsen, 1966, Geochim. Cosmochim. Acta, v. 3, p. 769-778; Brobst and Pratt, 1973, USGS Prof. Paper 820; Worl and Others, 1974, USGS MR-60; Kinkel and Peterson, 1962, USGS MR-13; RMAG, 1972, Geologic Atlas of the Rocky Mountain Region: Denver, CO; Bond and Others, 1978, Geologic Map of Idaho: IBMG; RosS, C.P., 1941, IBMG Pamph. 57, pt. 111; Mansfield, 1927, USGS Prof. Paper 152; Leonard and 0thers, 1978, USGS OFR 78-360; USGS, 1964, Mineral and Water Resources of İdaho: 88th U.S. Congress; Vine, 1959, USGS Bul1. 1055-1. 
ENERGY AND MINERAL RESOURCE EVALUATION - RARE II TRACTS

TRACT NO: 04154

TRACT NAME: Bonneville Peak

ECOREG: 3130

WAR: 18

NATIONAL FOREST: Caribou

STATE/COUNTY: Idaho, Bannock/Caribou

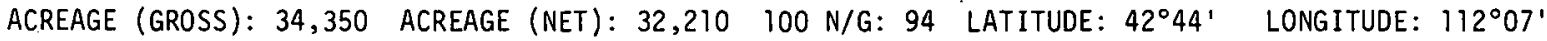

INDIVIDUAL TRACT

RESOURCE RATINGS

$\underline{\text { ORNL }} \quad \underline{\text { USFS }} \quad \underline{\mathrm{DOE}} \quad \underline{\mathrm{USGS}}$

REMARKS

OIL AND GAS

$4 / 1$

4

3

URANIUM

COAL

$2 / 1$

GEOTHERMAI

$1 / 4$

1

1

CRITICAL MINERALS

$2 / 2$

1

OVERALL RATING

(WEIGHTED)

$2 / 2$

1

$1^{+}$

3

NAMES OF CRITICAL MINERALS PRESENT: Base and precious metals?

COMMENTARY AND SUMMARY: Petroleum exploration has not been as initensive in the Paris-Bannock thrust. belt as in the more easterly thrust structures; however, several holes showing some oil and gas have been completed in the past. The Rocky Mountain $0 i l$ and Gas Association estimates that over 300 million barrels of oil and approximately three trillion cubic feet of gas occur in Rare II tracts in this belt. Phosphate resources are minor in comparison with the more easterly belts. Some potential for disseminated gold and base metals in the Precambrian and Lower Paleozoic strata is also present. DOE, low corridor R-49 conflict.

GEOLOGY: Paris-Bannock thrust belt (includes terrain between Paris-Bannock fault on east and the Wasatch fault and its northward projection on the west). The Wasatch fault is the major east boundary fault of the Basin and Range structural province and is generally normal in character, usually having a steep westward dip. Bedrock includes strata from the younger Precambrian, all Paleozoic systems, and Tertiary and Quaternary deposits. Tertiary and Quaternary volcanic rocks and similar age gravels locally cover the older rocks and structures.

REFERENCE/CITATION: USFS, 1978, RARE II DES, TI, IIT, and WY Suppls, ; DOE, 1978, Energy Res. Assessments of RARE II Lands; DOE, 1978, Energy Res. Assessments, of Ten Alternatives-RARE II Lands; Powers, 1977, WGA Gdbk 29; Blackstone, 1978, Tectonic map of the Overthrust Belt: WGS; RMOGA, 1978, Estimates of Undiscovered Recoverable Hydrocarbon Resources (RARE-II); White and Williams, 1975, USGS Circ. 726; NOAA, 1977, Geothermal Energy Resources of the Western U.S.; USGS, 1945, Min. Res. Mo. Valley Region, Pts. 1,2,3; ERDA, 1976, NURE-Prelim. Rpt.; Armstrong and Oriel, 1965, AAPG Bull., v. 43; British Sulfur Corp., Ltd., 1964, A World Survey of Phosphate Deposits: Woodalls Ltd. (Printers), London; Gulbrandsen, 1966, Geochim. Cosmochim. Acta, v. 3, p. 769-778; Brobst and Pratt, 1973, USGS Prof. Paper 820; Wor and Others, 1974, USGS MR-60; Kinkel and Peterson, 1962, USGS MR-13; RMAG, 1972, Geologic Atlas of the Rocky Mountain Region: Denver, CO; Bond and Others, 1978, Geologic Map of Idaho: IBMG; Ross, C.P., 1941 , IBMG Pamph. 57, pt. 111; Mansfield, 1927, USGS Prof. Paper 152; Leonard and 0thers, 1978, USGS OFR 78-360; USGS, 1964, Mineral and Water Resources of Idaho: 88th U.S. Congress; Vine, ig59, USGS Bu11. 1055-1. 
ENERGY AND MINERAL RESOURCE EVALUATION - RARE II TRACTS

TRACT NO: 04155

TRACT NAME: North Pebble

ECOREG: 3112

WAR: 17

NATIONAL FOREST: Caribou

STATE/COUNTY: Idaho, Caribou

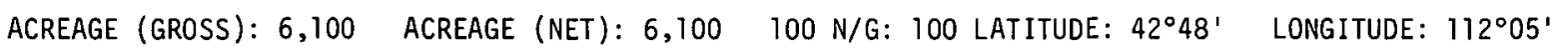

INDIVIDUAL TRACT

RESOURCE RATINGS

QRNL USFS DOE

R.EMAR.KS

OIL AND GAS

$4 / 1$

4

3

URAN IUM

$2 / 1$

1

1

COAL

$1 / 4$

1

1

GEOTHERMAL

$2 / 2 \quad 1$

CRITICAL MINERALS

$2 / 2$

1

OVERALL RATING

(WEIGHTED)

$1^{*}$

3

NAMES OF CRITICAL MINERALS PRESENT: Base and precious metals?

COMMENTARY AND SUMMARY: Petroleum explorațion has not been as intensive in the Paris-Bannock thrust. belt as in the more easterly thrust structures; however, several holes showing some oil and gas have been completed in the.past. The. Rocky Mountain 0il and Gas Association estimates that over 300 million. barrels of oil and approximately three trillion cubic feet of gas occur in Rare II tracts in this belt. Phosphate resources are minor in comparison with the more easterly belts. Some potential for disseminated gold and base metals in the Precambrian and Lower Paleozoic strata is also present.

GEOLOGY: Paris-Bannock thrust belt (includes terrain between Paris-Bannock fault on east and the Wasatch fault and its northward projection on the west). The Wasatch fault is the major east boundary fault of the Basin and Range structural province and is generally normal in character, usually having a steep westward dip. Bedrock includes strata from the younger Precambrian, all Paleozoic systems, and Tertiary and Quaternary deposits. Tertiary and Quaternary volcanic rocks and similar age gravels locally cover the older rocks and structures.

REFERENCE/CITATION: USFS, 1978, RARE II DES, ID, UT, and WY Suppls.; DOE, 1978, Energy Res. Assessments of RARE II Lands; DOE, 1978, Energy Res. Assessments, of Ten A7ternatives-RARE II Lands; Powers, 1977 , WGA Gdbk 29; Blackstone, 1978, Tectonic map of the Overthrust Belt: WGS; RMOGA, 1978, Estimates of Undiscovered Recoverable Hydrocarbon Resources (RARE-II); White and Williams, 1975, USGS Circ. 726 ; NOAA, 1977, Geothermal Energy Kesources of the Western U.S.; USGS, 1945, Min. Res. Mo. Valley Region, Pts. 1,2,3; ERDA, 1976, NURE-Prelim. Rpt.; Armstrong and Oriel, 1965, AAPG Bul1., v. 43; British Sulfur Corp., Ltd., 1964, A World Survey of Phosphate Deposits: Woodalls Ltd. (Printers), London; Gulbrandsen, 1966, Geochim. Cosmochim. Ncta, v. 3, p. 769-778; Brobst and Pratt, 1973, USGS Prof. Paper 820; Worl and Others, 1974, USGS MR-60; Kinkel and Peterson, 1962, USGS MR-13; RMAG, 1972, Geologic Atlas, of the Rocky Mourtain Region: Denver, C0; Bond and Others, 1978, Geologic Map of Idaho: IBMG; Ross, C.P., 1941, IBMG Pamph. 57, pt. 111; Mansfield, 1927, USGS Prof. Paper 152; Leonard and 0thers, 19.78, USGS OFR 78-360; USGS, 1964, Mineral and Water Resources of Idaho: 88th U.S. Congress; Vine, I959, USGS Bul1. 1055-1. 
ENERGY AND MINERAL RESOURCE EVALUATION - RARE II TRACTS

TRACT N0: 04156

NATIONAL FOREST: Caribou
TRACT NAME: Elkhorn Mounta in
ECOREG: 3130

WAR: 18

\begin{tabular}{|c|c|c|c|c|}
\hline $\begin{array}{l}\text { INDIVIDUAL TRACT } \\
\text { RESOURCE RATINGS } \\
\end{array}$ & $\underline{\text { ORNL }}$ & $\underline{\text { USFS }}$ & $\underline{\mathrm{DOE}}$ & $\underline{\text { USGS }}$ \\
\hline OIL AND GAS & $4 / 1$ & 4 & 3 & \\
\hline URANIUM & $2 / 1$ & 1 & 1 & \\
\hline COAL & $1 / 4$ & 1 & 1 & \\
\hline GEOTHERMAL & $3 / 2$ & 1 & & \\
\hline CRITICAL MINERALS & $2 / 2$ & 1 & & \\
\hline $\begin{array}{l}\text { OVERALL RATING } \\
\text { (WEIGHTED) }\end{array}$ & $1^{+}$ & & 3 & \\
\hline
\end{tabular}

STATE/COUNTY: Idaho, Oneida/Bannock

$100 \mathrm{~N} / \mathrm{G}: 99$ LATITUDE: $42^{\circ} 22^{\prime}$ LONGITUDE: $112^{\circ} 18^{\prime}$

NAMES OF CRITICAL MINERALS PRESENT: Base and precious metals?

COMMENTARY AND SUMMARY: Petroleum exploration has not been as intensive in the Paris-Bannock thrust belt as in the more easterly thrust structures; however, several holes showing some oil and gas have been completed in the past. The Rocky Mountain 0il and Gas Association estimates that over 300 million barrels of $0 i 1$ and approximately three trillion cubic feet of gas occur in Rare II tracts in this belt: Phosphate resources are minor in comparison with the more easterly belts. Some potential for disseminated gold and base metals in the Precambrian and Lower Paleozoic strata is also present. DOE, high conflict, corridor R-50.

GEOLOGY: Paris-Bannock thrust belt (includes terrain between Paris-Bannock fault on east and the wasatch fault and its northward projection on the west). The Wasatch fault is the major east boundary fault of the Basin and Range structural province and is generally normal in character, usually having a steep westward dip. Bedrock includes strata from the younger Precambrian, all Paleozoic systems, and Tertiary and Quaternary deposits. Tertiary and Quaternary volcanic rocks and similar age gravels locally cover the older rocks and structures.

REFERENCE/CITATION: USFS, 1978, RARE II DES, ID, UT, and WY Suppls.; D0E, 1978, Energy Res. Assessments of RARE II Lands; DOE, 1978, Energy Res. Assessments, of Ten Alternatives-RARE II Lands; Powers, 1977, WGA Gdbk 29; Blackstone, 1978, Tectonic map of the Overthrust Belt: WGS; RMOGA, 1978, Estimates of Undiscovered Recoverable Hydrocarbon Resources (RARE-II); White and Williams, 1975, USGS Circ. 726; NOAA, 1977, Geothermal Energy Resources of the Western U.S.; USGS, 1945, Min. Res. Mo. Valley Region, Pts. 1,2,3; ERDA, 1976, NURE-Prelim. Rpt.; Armstrong and Oriel, 1965, AAPG Bul1.., v. 43; British Sulfur Corp., Ltd., 1964, A World Survey of Phosphate Deposits: Woodalls Ltd. (Printers), London; Gulbrandsen, 1966, Geochim. Cosmochim. Acta, v. 3, p. 769-778; Brobst and Pratt, 1973, USGS Prof. Paper 820; Worl and Others, 1974, USGS MR-60; Kinkel and Peterson, 1962, USGS MR-13; RMAG, 1972, Geologic Atlas of the Rocky Mountain Region: Denver, C0; Bond and Others, 1978, Geologic Map of Idaho: IBMG; Ross, C.P., 1941, IBMG Pamph. 57, pt. 111; Mansfield, 1927, USGS Prof. Paper 152; Leonard and 0thers, 1978, USGS OFR 78-360; USGS, 1964, Mineral and Water Resources of Idaho: 88th U.S. Congress; Vine, 1959, USGS Bu11. 1055-1. 
ENERGY AND MINERAL RESOURCE EVALUATION - RARE II TRACTS

TRACT NO: 04157

NATIONAL FOREST: Caribou
TRACT' NAME: Oxford Mountain

ECOREG : 3112

WAR: 16

STATE/COUNTY: Idaho, Oneida/Bannock/Frankl in
ACREAGE (GROSS): 43,100 ACREAGE (NET): $42,480 \quad 100 \mathrm{~N} / \mathrm{G}: 99$ LATITUDE: $42^{\circ} 15^{\prime}$ LONGITUDE: $112^{\circ} 06^{\prime}$

INDIVIDUAL TRACT

RESOURCE RATINGS

$\underline{\text { ORNL }} \underline{\text { USFS }} \underline{\mathrm{OUU}} \quad \underline{\text { USGSS }}$

REMARKS

OIL AND GAS

$4 / 1$

4

3

URAN IUM

$2 / 1$

1

1

COAL

$$
1 / 4
$$

1

1

GEOTHERMAL

$3 / 2$

1

CRITICAL MINERALJ

$2 / 1$

1

OVERALL RATING

(WEIGHTED)

$1^{+}$

3

NAMES OF CRITICAL MINERALS PRESENT: Base metals?

COMMENTARY AND SUMMARY: Petroleum exploration has not been as intensive in the Paris-Bannock thrust belt as in the more easterly thrust structures; however, several holes showing some oil and gas have been completed in the past. The Rocky Mountain $0 i 1$ and Gas Association estimates that over 300 million barrels of oil and approximately three trillion cubic feet of gas occur in Rare II tracts in this belt. Phosphate resources are minor in comparison with the more easterly belts. Some potential for disseminated gold and base metals in the Precambrian and Lower Paleozoic strata is also present. DOE, moderate corridor R-5l conflict.

GEOLOGY: Paris-Bannock thrust belt (includes terrain between Paris-Bannock fault on east and the Wasatch fault and its northward projection on the west). The Wasatch fault is the major east boundary fault of the Basin and Range structural province and is generally normal in character, usually having a steep westward dip. Bedrock includes strata from the younger Precambrian, all Paleozoic systems, and Tertiary and Quaternary deposits. Tertiary and Quaternary volcanic rocks and similar age gravels locally cover the older rocks and structures.

REFERENCE/CITATION: USFS, 1978, RARE II DES, ID, UT, and WY Suppls.; DOE, 1978, Energy Res. Assessments of RARE II Lands; DOE, 1978, Energy Res. Assessments, of Ten Alternatives-RARE II Lands; Powers, 1977 , WGA Gdbk 29; Blackstone, 1978, Tectonic map of the Overthrust Belt: WGS; RMnGA, 1978, Estimates of Undiscovered Recoverable Hydrocarbon Resources (RARE-II); White and Williams, 1975, USGS Circ. 726; NOAA, 1977, Geothermal Energy Resources of the Western U.S.; USGS, 1945, Min. Res. Mo. Valley Region, Pts. 1,2,3; ERDA, 1976, NURE-Prelim. Rpt.; Armstrong and Oriel, 1965, AAPG Bull., v. 43; British Sulfur Corp., Ltd., 1964, A World Survey of Phosphate Deposits: Woodalls Ltd. (Printers), London; Gulbrandsen, 1966, Geochim. Cosmochim. Acta, v. 3, p. 769-778; Brobst and Pratt, 1973, USGS Prof. Paper 820; Worl and Others, 1974, USGS MR-60; Kinkel and Peterson, 1962, USGS MR-13; RMAG, 1972, Geologic Atlas of the Rocky Mountain Region: Denver, C0; Bond and Others, 1978, Geologic Map of Idaho: IBMG; Ross, C.P., 1941, IBMG Pamph. 57, pt. 111; Mansfield, 1927, USGS Prof. Paper 152; Leonard and Others, 1978, USGS OFR 78-360; USGS, 1964, Mineral and Water Resources of Idaho: 88th U.S. Congress; Vine, 1959, USGS Bul1. 1055-1. 
ENERGY AND MINERAL. RESOURCE EVALUATION - RARE II TRACTS

TRACT NO: 04158

TRACT NAME: Deep Creek

ECOREG: 3130

WAR: 14

NATIONAL FOREST: Caribou

STATE/COUNTY: Idaho, Oneida

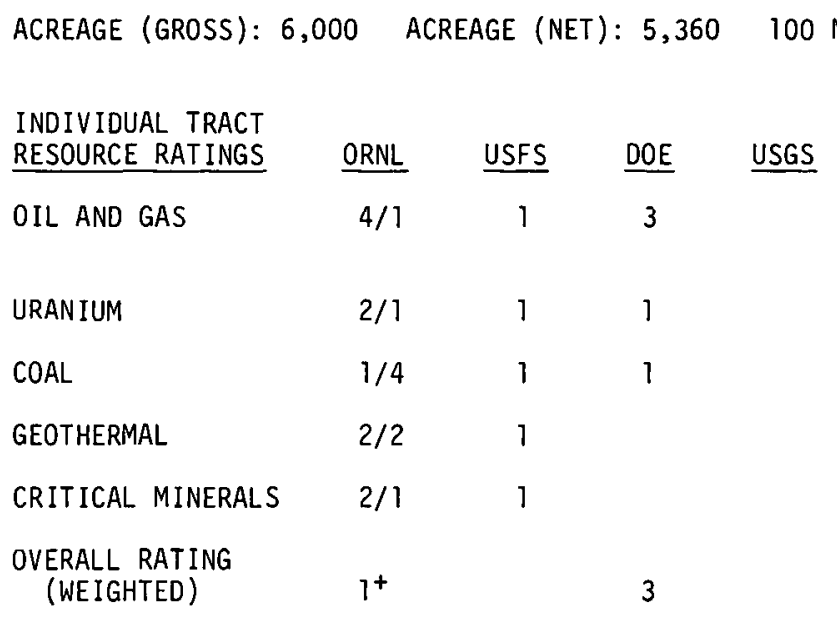

REMARKS

Stratigraphic and structural traps compounded by thrusting; similar to Canadian Rockies Fonthills Beit

NAMES OF CRITICAL MINERALS PRESENT: $\mathrm{Cu}-\mathrm{Pb}$ ?

COMMENTARY AND SUMMARY: Petroleum exploration has not been as intensive in the Paris-Bannock thrust belt as in the more easterly thrust structures; however, several holes showing some oil and gas have been completed in the past. The Rocky Mountain 0il and Gas Association estimates that over 300 million barrels of oil and approximately three trillion cubic feet of gas occur in Rare II tracts in this belt. Phosphate resources are minor in comparison with the more easterly belts. Some potential for dis-. seminated gold and base metals in the Precambrian and Lower Paleozoic strata is also present. DOE, moderate corridor R-57 conflict.

GEOLOGY: Paris-Bannock thrust belt (includes terrain between Paris-Bannock fault on east and the Wasatch fault and its northward projection on the west). The Wasatch fault is the major east boundary fault of the Basin and Range structural province and is generally normal in character, usually having a steep westward dip. Bedrock includes strata from the younger Precambrian, all Paleozoic systems, and Tertiary and Quaternary deposits. Terliary and Quaternary volcanic rocks and similar age gravels locally cover the older rocks and structures.

REFERENCE/CITATION: USFS, 1978, RARE II DES, ID, UT, and WY Suppls.; D0E, 1978, Energy Res. Assessments of RARE II Lands; DOE, 1978, Energy Res. Assessments, of Ten Alternatives-RARE II Lands; Powers, 1977 , WGA Gdbk 29; Blackstone, 1978, Tectonic map of the Overthrust Belt: WGS; RMOGA, 1978, Estimates of Undiscovered Recoverable Hydrocarbon Resources (RARE-II); White and Williams, 1975, USGS Circ. 726 ; NOAA, 1977, Geothermal Energy Resources of the Western U.S.; USGS, 1945, Min. Res. Mo. Valley Region, Pts. 1,2,3; ERDA, 1976, NURE-Prel im. Rpt.; Armstrong and Oriel, 1965, AAPG Bull., v. 43; British Sulfur Corp., Ltd., 1964, A World Survey of Phosphate Deposits: Woodalls Ltd. (Printers), London; Gulbrandsen, 1966, Geochim. Cosmochim. Acta, v. 3, p. 769-778; Brobst and Pratt, 1973, USGS Prof. Paper 820; Worl and Others, 1974, USGS MR-60; Kinkel and Peterson, 1962, USGS MR-13; RMAG, 1972, Geologic Atlas of the Rocky Mounta in Region: Denver, CO; Bond and Others, 1978, Geologic Map of Idaho: IBMG; Ross, C.P., 1941, IBMG Pamph. 57, pt. 111; Mansfield, 1927, USGS Prof. Paper 152; Leonard and 0thers, 1978, USGS OFR 78-360; USGS, 1964, Mineral and Water Resources of Idaho: 88th U.S. Congress; Vine, 1959, USGS Bul1. 1055-1. 
ENERGY AND MINERAL RESOURCE EVALUATION - RARE II TRACTS

TRACT N0: 04159

NATIONAL FOREST: Caribou

TRACT NAME: Clarkston Mountain

ECOREG: 3130

WAR: 15

STATE/COUNTY: Idaho/Utah, Uneida/tIdèr/Lache .

ACREAGE (GROSS): 21,900 ACREAGE (NET): $19,120 \quad 100 \mathrm{~N} / \mathrm{G}: 87$ LATITUDE: $42^{\circ} 03^{\prime}$ LONGITUDE: $112^{\circ} 10^{\prime}$

INDIVIDUAL TRACT

RLSOURCE RATINGS

OIL AND GAS

ORNL

$4 / 1$

USFS

4

$\underline{\mathrm{DOE}}$

IISGS

URANIUM

COAL

GEOTHERMAL

CRITICAL MINERALS

$2 / 1$

$1 / 4$

1

i

1

$2 / 2$

1

OVERALL RATING

(WEIGHTED)
$2 / 1$

$1^{+}$

NAMES OF CRITICAL MINERALS PRESENT: Base metals?

COMMENTARY AND SUMMARY: Petroleum exploration has not been as intensive in the Paris-Bannock thrust belt as in the more easterly thrust structures; however, several holes showing some oil and gas have been completed in the past. The Rocky Mountain 0 il and Gas Association estimates that over 300 million barrels of oil and approximately three trillion cubic feet of gas occur in Rare II tracts in this belt. Phosphate resources are minor in comparison with the more easterly belts. Some potential for disseminated gold and base metals in the Precambrian and Lower Paleozoic strata is also present.

GEOLOGY: Paris-Bannock thrust belt (includes terrain between Paris-Bannock fault on east and the Wasatch fault and its northward projection on the west). The Wasatch fault is the major east boundary fault of the Basin and Range structural province and is generally normal in character, usually having a steep westward dip. Bedrock includes strata from the younger Precambrian, all Paleozoic systems, and Tertiary and Quaternary deposits. Tertiary and Quaternary volcanic rocks and similar age gravels locally cover the older rocks and structures.

REFERENCE/CITATION: USFS, 1978, RARE II DES, ID, UT, and WY Suppls.; D0E, 1978, Energy Res. Assessments of RARE II Lands; DOE, 1978, Energy Res. Assessments, of Ten Alternatives-RARE II Lands; Powers, 1977 , WGA Gdbk 29; Blackstone, 1978, Tectonic map of the Overthrust Belt: WGS; RMOGA, 1978, Estimates of Undiscovered Recoverable Hydrocarbon Resources (RARE-II); White and Williams, 1975, USGS Circ. 726; NOAA, 1977, Geothermal Energy Resources of the Western U.S.; USGS, 1945, M1n. Res. Mu. Vdlley Region, Pts. 1,2,3; ERDA, 1976, NURE-Prelim. Rpt.; Armstrong and Oriel, 1965, AAPG Bul1., v. 43; British Sulfur Corp., Ltd., 1964, A World Survey of Phosphate Deposits: Woodalls Ltd. (Printers), London; Gulbrandsen, 1966, Geochim. Cosmochim. Acta, v. 3, p. 769-778; Brobst and Pratt, 1973, USGS Prof. Paper 820; Worl and 0thers, 1974, USGS MR-60; Kinke1 and Peterson, 1962, USGS MR-13; RMAG, 1972, Geologic At1as of the Rocky Mountain Region: Denver, C0; Bond and Others, 1978, Geologic Map of Idaho: IBMG; Ross, C.P., 1941, IBMG Pamph. 57, pt. 111; Mansfield, 1927, USGS Prof. Paper 152; Leonard and 0thers, 1978, US@S OFR 78-360; USGS, 1964, Mineral and Water Resources of Idaho: 88th U.S. Congress; Vine, 1959, USGS Bul1. 1055-1. 
ENERGY AND MINERAL RESOURCE EVALUATION - RARE II TRACTS

TRACT N0: 04160

TRACT NAME: Pole Creek

ECOREG : 3112

WAR: 15

NATIONAL FOREST: Caribou/Targhee

STATE/COUNTY: Idaho, Bonneville

ACREAGE (GROSS): 8,900 ACREAGE (NET): 8,900

$100 \mathrm{~N} / \mathrm{G}: 100$ LATITUDE: $43^{\circ} 10^{\prime}$ LONGITUDE: $111^{\circ} 22^{\prime}$

\begin{tabular}{|c|c|c|c|c|c|}
\hline $\begin{array}{l}\text { INDIVIDUAL TRACT } \\
\text { RESOURCE RATINGS } \\
\end{array}$ & ORNL & USFS & DOE & USGS & REMARKS \\
\hline OIL AND GAS & $4 / 4$ & 4 & 4 & & $\begin{array}{l}\text { Stratigraphic and struct } \\
\text { pounded by thrusting; si } \\
\text { Rockies Foothills Belt }\end{array}$ \\
\hline URANIUM & $2 / 1$ & 1 & 1 & & \\
\hline COAL & $1 / 4$ & 1 & 1 & & \\
\hline GEOTHERMAL & $2 / 2$ & 1 & & & \\
\hline CRITICAL MINERALS & $4 / 4$ & 1 & & & Mt. Pisgah gold district \\
\hline $\begin{array}{l}\text { OVERALL RATING } \\
\text { (WEIGHTED) }\end{array}$ & $3^{+}$ & & 4 & & Small acreage \\
\hline
\end{tabular}

NAMES OF CRITICAL MINERALS PRESENT:

COMMENTARY AND SUMMARY: Several major and several lesser oil and/or gas fields are located in the southern part of the Absaroka Belt in Wyoming and Utah. Most production is from Jurassic-Triassic reservoirs, but more recent deeper discoveries are in Upper Paleozoic rocks (Phosphoria) and even more recently in Lower Paleozoic rocks. The Rocky Mountain 0il and Gas Association estimates that Rare II tracts in the Absaroka belt contain nearly 3.3 billion barrels of oil and over 12.5 trillion cubic feet of gas. The major part of the Southeast Idaho phosphate resource is in this thrust belt, with much of it in the Rare II tracts. Not only are the phosphate rock resources important for the phosphorus, but there is a significant near-future potential for vanadium, uranium by-product production. The Mt. Pisgah gold district in Bonneville County may have significant potential for Carlin-type gold deposits (Rare II tracts 04160, 04161, and 04162).

G[OLOGY: Absaruka thrusl be]t (Includes cerrain westward to surface trace of the Paris-Bannock thrust complex). Includes (as secondary structures) the Crawford, Mcade, Medicine Lodge, Sheep Mountain, Skyline, and many smaller thrust faults. Rocks exposed at the surface include sedimentary rocks from Cambrian to Tertiary in age along with some Tertiary and Quaternary volcanics. Several small igneous intrusions of Tertiary Age have been mapped in the Idaho part of the Absaroka Belt, chiefly in the vicinity of the Mt. Pisgah gold district.

REFERENCE/CITATION: USFS, 1978, RARE II DES, ID, UT, and WY Suppls.; DOE, 1978, Energy Res. Assessments of RARE II Lands; DOE, 1978, Energy Res. Assessments, of Ten A1ternatives-RARE II Lands;. Powers, 1977, WGA Gdbk 29; Blackstone, 1978, Tectonic map of the Overthrust Belt: WGS; RMOGA, 1978, Estimates of Undiscovered Recoverable Hydrocarbon Resources (RARE-II); White and Williams, 1975, USGS. Circ. 726; NOAA, 1977, Geothermal Energy Resources of the Western U.S.; USGS, 1945, Min. Res. Mo. Valley Region, Pts. 1,2,3; ERDA: 1976, NURE-Prelim. Rpt.; Armstrong and Oriel, 1965, AAPG Bull., v. 43; British Sulfur Corp., Ltd., 1964, A World Survey of Phosphate Deposits: Woodalls Ltd. (Printers), London; Gulbrandsen, 1966, Geochim. Cosmochim. Acta, v. 3, p. 769-778; Brobst and Pratt, 1973, USGS Prof. Paper 820; Worl and Others, 1974, USGS MR-60; Kinkel and Peterson, 1962, USGS MR-13; RMAG, 1972, Geologic Atlas of the Rocky Mountain Region: Denver, CO; Bond and Others, 1978, Geologic Map of Idaho: IBMG; Ross, C.P., 1941, IBMG Pamph. 57, pt. 111; Mansfield, 1927, USGS Prof. Paper 152; Leonard and Others, I978,.'USGS OFR 78-360; USGS, 1964, Mineral and Water Resources of Idaho: 88th U.S. Congress; Vine, 1959, USGS Bu11. 1055-1. 
ENERGY AND MINERAL RESOURCE EVALUATION - RARE II TRACTS

TRACT NO: 04161

TRACT NAME: Caribou City

ECOREG: 3112

WAR: 22

NATIONAL FOREST: Caribou/Targhee

ACREAGE (GROSS): 93,460 ACREAGE (NET): $92,880100 \mathrm{~N} / \mathrm{G}: 99$ LATITUDE: $43^{\circ} 04^{\prime}$ LONGITUDE: $111^{\circ} 12^{\prime}$
INDIVIDUAL TRACT

RESOURCE KAILNGS

OIL AND GAS

URANIUM

COAL

GEOTHERMAL

CRITICAL MINERALS

OVERALL RATING

(WEIGHTED)

\begin{tabular}{|c|c|c|}
\hline ORNL & USFS & DOE \\
\hline $4 / 4$ & 4 & 4 \\
\hline $2 / 1$ & 1 & 1 \\
\hline $4 / 2$ & 1 & 1 \\
\hline $2 / 2$ & 1 & \\
\hline $4 / 4$ & 1 & \\
\hline 4 & & 4 \\
\hline
\end{tabular}

RCMARKS

Stratigraphic and structural traps compounded by thrusting; similar to Canadian Rockies Foothills Belt

Teton basin field

Mt. Pisgah gold district

NAMES OF CRITICAL MINERALS PRESENT:

COMMENTARY AND SUMMARY: Several major and several lesser oil and/or gas fields are located in the southern part of the Absaroka Belt in Wyoming and Utah. Most production is from Jurassic-Triassic reservoirs, but more recent deeper discoveries are in Upper Paleozoic rocks (Phosphoria) and even more recently in Lower Paleozoic rocks. The Rocky Mountain 0il and Gas Association estimates that Rare II tracts in the Absaroka belt contain nearly 3.3 billion barrels of oil and over 12.5 trillion cubic feet of gas. The major part of the Southeast Idaho phosphate resource is in this thrust bull, wllh Illucli of $i t$ in the Rare II tracts. Not only are the phosphate rock resources important for the phosphorus, but there is a significant near-future potential for vanadium, uranium by-product production. The Mt. Pisgah gold district in Bonneville County may have significant potential for Carlin-type gold deposits (Rare II tracts 04160, 04161, and 04162).

GEOLOGY: Absaroka thrust belt (includes terrain westward to surface trace of the Paris-Bannock thrust complex). Includes (as secondary structures) the Crawford, Meade, Medicine Lodge, Sheep Mountain, Skyline, and many smaller thrust faults. Rocks exposed at the surface include sedimentary rocks from Cambrian to Tertiary in age along with some Tertiary and Quaternary volcanics. Several small igneous intrusions of Tertiary Age have been mapped in the Idaho part of the Absaroka Belt, chiefly in the vicinity of the Mt. Pisgah gold district.

REFERENCE/CITATION: USFS, 1978, RARE II DES, ID, UT, and WY Suppls.; DUE, 19/8, Enërgy Res. Assessments of RARE II Lands; DOE, 1978, Energy Res. Assessments, of Ten Alternatives-RARE II Lands; Powers, 1977, WGA Gdbk 29; Blackstone, 1978, Tectonic map of the Overthrust Belt: WGS; RMOGA, 1978, Estimates of Undiscovered Recoverable Hydrocarbon Resources (RARE-II); White and Williams, 1975, USGS C1rC. 726; NOAA, 1977, Geothermal Energy Resources of the Western U.S.; USGS, 1945, Min. Res. Mo. Valley Region, Pts. 1,2,3; ERDA, 1976, NURE-Prelim. Rpt.; Armstrong and Oriel, 1965, AAPG Bul1., v. 43; British Sulfur Corp., Ltd., 1964, A World Survey of Phosphate Deposits: Woodalls Ltd. (Printers), London; Gulbrandsen, 1966, Geochim. Cosmochim. Acta, v. 3, p. 769-778; Brobst and Pratt, 1973, USGS Prof. Paper 820; Worl and Others, 1974, USGS MR-60; Kinkel and Peterson, 1962, USGS MR-13; RMAG, 1972, Geologic Atlas of the Rocky Mounta in Region: Denver, C0; Bond and Others, 1978, Geologic Map of Idaho: IBMG; Ross, C.P., 1941, IBMG Pamph. 57, pt. 111; Mansfield, 1927, USGS Prof. Paper 152; Leonard and 0thers, 1978, USGS OFR 78-360; USGS, 1964, Mineral and Water Resources of Idaho: 88th U.S. Congress; Vine, 1959, USGS Bu11. 1055-1. 
ENERGY AND MINERAL RESOURCE EVALUATION - RARE II TRACTS

TRACT NO: 04162

TRACT NAME: Stump Creek

ECOREG : 3112

WAR: 22

NATIONAL FOREST: Caribou

STATE/COUNTY: Idaho, Caribou

ACREAGE (GROSS): 103,640 ACREAGE (NET): $103,200100 \mathrm{~N} / \mathrm{G}: 100$ LATITUDE: $42^{\circ} 50^{\prime}$ LONGITUDE: $11^{\circ} 11^{\prime}$

INDIVIDUAL TRACT

RESOURCE RATINGS

ORN

OIL AND GAS

$4 / 2$

USFS

$\underline{D O E}$

$\underline{\text { USGS }}$

4

URANIUM

COAL

GEOTHERMAL

CRITICAL MINERALS

$$
2 / 1
$$

$4 / 2$

\section{1}

1

1

1

$3^{+} / 2 \quad 1$

OVERALL RATING

(WEIGHTED)
$2 / 1$

1

\author{
Stratigraphic and structural traps com- \\ pounded by thrusting; similar to Canadian \\ Rockies Foothills Beit
}

Teton basin field

Possible extension of Mt. Pisgah goldbearing formations

NAMES OF CRITICAL MINERALS PRËSENT:

COMMENTARY AND SUMMARY: Several major and several lesser oil and/or gas fields are located in the . southern part of the Absaroka Belt in Wyoming and Utah. Most production is from Jurassic-Triassic reservoirs, but more recent deeper discoveries are in Upper Paleozoic rocks (Phosphoria) and even more recently in Lower Paleozoic rocks. The Rocky Mountain Oil and Gas Association estimates that Rare II tracts in the Absaroka belt contain nearly 3.3 billion barrels of oil and over 12.5 trillion cubic feet of gas. The major part of the Southeast Idaho phosphate resource is in this thrust belt, with much of it in the Rare II tracts. Not only are the phosphate rock resources important for the phosphorus, but there is a significant near-future potential for vanadium, uranium by-product production. The Mt. Pisgah gold district in Bonneville County may have significant potential for Carlin-type gold deposits (Rare II tracts 04160, 04161, and 04162). DOE, moderate corridor R-45 conflict.

GEOLOGY: Absaroka thrust belt (includes terrain westward to surface trace of the Paris-Bannock thrust complex). Includes (as secondary structures) the Crawford, Meade, Medicine Lodge, Sheep Mountain, Skyline, and many smaller thrust faults. Rocks exposed at the surface include sedimentary rocks from Cambrian to Tertiary in age along with some Tertiary and Quaternary volcanics. Several small igneous intrusions of Tertiary Age have been mapped in the Idaho part of the Absaroka Belt, chiefly in the vicinity of the Mt. Pisgah gold district.

REFERENCE/CITATION: USFS, 1978, RARE II DES, ID, UT, and WY Suppls.; DOE, 1978, Energy Res. Assessments of RARE II Lands; DOE, 1978, Energy Res. Assessments, of Ten Alternatives-RARE II Lands; Powers, 1977, WGA Gdbk 29; Blackstone, 1978, Tectonic map of the Overthrust Belt: WGS; RMOGA, 1978, Estimates of Undiscovered Recoverable Hydrocarbon Resources (RARE-II); White and Williams, 1975, USGS Circ. 726; NOAA, 1977, Geothermal Energy Resources of the Western U.S.; USGS, 1945, Min. Res. Mo. Valley Region, Pts. 1,2,3; ERDA, 1976, NURE-Prelim. Rpt.; Armstrong and Oriel, 1965, AAPG Bul1., v. 43; British Sulfur Corp., Ltd., 1964, A World Survey of Phosphate Deposits: Woodalls Ltd. (Printers), London; Gulbriandsen, 1966, Geochim. Cosmochim. Acta, v. 3, p. 769-778; Brobst and Pratt, 1973, USGS Prof. Paper 820; Worl and Others, 1974, USGS MR-60; Kinkel and Peterson, 1962, USGS MR-13; RMAG, 1972, Geologic At Tas of the Rocky Mounta in Region: Denver, CO; Bond and Others, 1978, Geologic Map of Idaho: IBMG; Ross, C.P. , 1941, IBMG Pamph. 57, pt. 111; Mansfield, 1927, USGS Prof. Paper 152; Leonard and 0thers, 1978, USGS OFR 78-360; USGS, 1964, Mineral and Water Resources of Idaho: 88th U.S. Congress; Vine, 1959, USGS Bul1. 1055-1. 
ENERGY AND MINERAL RESOURCE EVALUATION - RARE II TRACTS

TRACT NO: 04163

TRACT NAME: Schmid Peak

ECOREG: 3112

WAR: 17

NATIONAL FOREST: Caribou

STATE/COUNTY: Idaho, Caribou

ACREAGE (GROSS): 10,920 ACREAGE (NET): $10,830100 \mathrm{~N} / \mathrm{G}: 99$ LATITUDE: $42^{\circ} 45^{\prime}$ LONGITUDE: $110^{\circ} 15^{\prime}$

INDIVIDUAL TRACT RESOURCE RATINGS

OIL AND GAS

$\underline{\text { ORNL }} \underline{\text { USFS }} \underline{\mathrm{DOE}} \quad \underline{\text { USGS }}$

$\begin{array}{lll}4 / 2 & 4 & 4\end{array}$

URANIUM

COAL

GEOTHERMAL

CRITICAL MINERALS

$2 / 2$

$1 / 3$

I

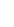

$2 / 2$

$4 / 4$

3

OVERALL RATING

(WEIGHTED)

4
REMARKS

Stratigraphic and structural traps compounded by thrusting; similar to Canadian Rockies Foothills Belt

NAMES OF CRITICAL MINERALS PRESENT: $P(U, V, F, \mathrm{Zn}, \mathrm{Cd}, \mathrm{Cr}$ )

COMMENTARY AND SUMMARY: Several major and several lesser oill and/or gas fields are located in the southern part of the Absaroka Belt in Wyoming and Utah. Most production is from Jurassic-Triassic reservoirs, but more recent deeper discoveries are in Upper Paleozoic rocks (Phosphoria) and even more recently in Lower Paleozoic rocks. The Rocky Mountain Oil and Gas Association estimates that Rare II tracts in the Absaroka belt contain nearly 3.3 billion barrels of oil and over 12.5 trillion cubic feet of gas. The major part of the Southeast Idaho phosphate resource is in this thrust belt, with much of it in the Rare II tracts. Not only are the phosphate rock resources important for the phosphorus, but there is a significant near-future potential for vanadium, uranium by-product production. The Mt. Pisgah gold district in Bonneville County may have significant potential for Carlin-type gold deposits (Rare II tracts 04160, 04161, and 04162). D0E, moderate corridor R-45 conflict.

GEOLOGY: Absaroka thrust belt (includes terrain westward to surface trace of the Paris-Bannock thrust complex). Includes (as secondary structures) the Crawford, Meade, Medicine Lodge, Sheep Mountaln, Skyline, and many smaller thrust faults. Rocks exposed at the surface include sedimentary rocks from Cambrian to Tertiary in age along with some Tertiary and Quaternary volcanics. Several small igneous intrusions of Tertiary Age have been mapped in the Idaho part of the Absaroka Belt, chiefly in the vicinity of the Mt. Pisgah gold district.

REFERENCE/CITATION: USFS, 1978, RARE II DES, ID; UT, and WY Suppls.; DOE, 1978, Energy Res. Assessments of KAKt II Lands; DOE, 1978, Energy Res. Assessments, of Ten Aīternatives-RARE II Lands; Powers, 1977 , WGA Gdbk 29; Blackstone, 1978, Tectonic map of the Overthrust Belt: WGS; RMOGA, 1978, Estimates of Undiscovered Recoverable Hydrocarbon Resources (RARE-II); White and Williams, 1975, USGS Circ. 726; NOAA, 1977, Geothermal Energy Resources of the Western U.S.; USGS, 1945, Min. Res. Mo. Valley Region, Pts. 1,2,3; ERDA, 1976, NURE-Prelim. Rpt.; Armstrong and Orie1, 1965, AAPG Bul1., v. 43; British Sulfur Corp., Ltd., 1964, A World Survey of Phosphate Deposits: Woodalls Ltd. (Printers), London; Gulbrandsen, 1966, Geochim. Cosmochim. Acta, v. 3, p. 769-778; Brobst and Pratt, 1973, USGS Prof. Paper 820; Wor1 and Others, 1974, USGS MR-60; Kinkel and Peterson, 1962, USGS MR-13; RMAG, 1972, Geologic Atlas of the Rocky Mounta in Region: Denver, CO; Bond and Others, 1978, Geologic Map of Idaho: IBMG; Ross, C.P., 1941, IBMG Pamph. 57, pt. 111; Mansfie1d, 1927, USGS Prof. Paper 152; Leonard and Others, 1978, USGS OFR 78-360; USGS, 1964, Mineral and Water Resources of Idaho: 88th U.S. Congress; Vine, 1959, USGS Bul1. 1055-1. 
ENERGY AND MINERAL RESOURCE EVALUATION - RARE II TRACTS

TRACT NO: 04164

NATIONAL FOREST: Caribou
TRACT NAME: Dry Ridge

ECOREG: 3112

WAR: 16

STATE/COUNTY: Idaho, Caribou/Bear Lake

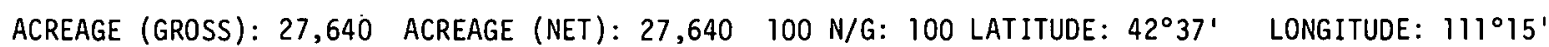

INDIVIDUAL TRACT

RESOURCE RATINGS

OIL AND GAS

$\underline{\text { ORNL }}$

$\underline{\text { USFS }}$

DOE

$\underline{\text { USGS }}$

$\begin{array}{lll}4 / 3 & 4 & 4\end{array}$

URANIUM

COAL

GEOTHERMAL

CRITICAL MINERALS

OVERALL RATING

(WEIGHTED)

$\begin{array}{lll}2 / 2 & 1 & 1\end{array}$

$\begin{array}{lll}1 / 3 & 1\end{array}$

$2 / 2 \quad 1$

$4 / 4 \quad 4$

$3^{+}$
REMARKS

Stratigraphic and structural traps compounded by thrusting; similar to Canadian Rockles Foothills Belt

NAMES OF CRITICAL MINERALS PRESENT: $P(U, V, F, Z n, C d, C r)$

COMMENTARY AND SUMMARY: Several major and several lesser oil and/or gas fields are located in the southern part of the Absaroka Belt in Wyoming and Utah. Most production is from Jurassic-Triassic reservoirs, but more recent deeper discoveries are in Upper Paleozoic rocks (Phosphoria) and even more recently in Lower Paleozoic rocks. The Rocky Mountain 0 il and Gas Association estimates that Rare II tracts in the Absaroka belt contain nearly 3.3 billion barrels of oil and over 12.5 trillion cubic feet of gas. The major part of the Southeast Idaho phosphate resource is in this thrust belt, with much of it in the Rare II tracts. Not only are the phosphate rock resources important for the phosphorus, but there is a significant near-future potential for vanadium, uranium by-product production. The Mt. Pisgah gold district in Bonneville County may have significant potential for Carlin-type gold deposits (Rare II tracts 04160, 04161, and 04162).

GEOLOGY: Absaroka thrust belt (includes terrain westward to surface trace of the Paris-Bannock thrust cumplex). Includes (as secondary structures) the Crawford, Meade, Medicine Lodge, Sheep Mountain, Skyline, and many smaller thrust faults. Rocks exposed at the surface include sedimentary rocks from Cambrian to Tertiary in age along with some Tertiary and Quaternary volcanics. Several small igneous intrusions of Tertiary Age have been mapped in the Idaho part of the Absaroka Belt, chiefly in the vicinity of the Mt. Pisgah gold district.

REFERENCE/CITATION: USFS, 1978, RARE II DES, ID, UT, and WY Suppls.; DOE, 1978, Energy Res. Assessments of RARE II Lands; D0E, 1978, Energy Res. Assessments, of Ten Alternatives-RARE II Lands; Powers, 1977, WGA Gdbk 29; Blackstone, 1978, Tectonic map of the Overthrust Belt: WGS; RMOGA, 1978, Estimates of Undiscovered Recoverable Hydrocarbon Resources (RARE-II); White and Williams, 1975, USGS Circ. 726; NOAA, 1977, Geothermal Energy Resources of the Western U.S.; USGS, 1945, Min. Res. Mo. Valley Region, Pts. 1,2,3; ERDA, 1976, NURE-Prelim. Rpt.; Armstrong and Oriel, 1965, AAPG Bul1., v. 43; British Sulfur Corp., Ltd., 1964, A World Survey of Phosphate Deposits: Woodalls Ltd. (Printers), London; Gulbrandsen, 1966, Geochim. Cosmochim. Acta, v. 3, p. 769-778; Brobst and Pratt, 1973, USGS Prof. Paper 820; Worl and Others, 1974, USGS MR-60; Kinkel and Peterson, 1962, USGS MR-13; RMAG, 1972, Geologic Atlas of the Rocky Mountain Region: Denver, CO; Bond and Others, 1978, Geologic Map of Idaho: IBMG; Ross, C.P.; 1947, IBMG Pamph. 57, pt. 111; Mansfield, 1927, USGS Prof. Paper 152; Leonard and 0thers, 1978, USGS OFR 78-360; USGS, 1964, Mineral and Water Resources of Idaho: 88th U.S. Congress; Vine, ig59, USGS Bul1. 1055-1. 
ENERGY AND MINERAL RESOURCE EVALUATION - RARE II TRACTS

TRACT NO: 04165

TRACT NAME: Huckleberry Basin

ECOREG: 3112

WAR: 20

NATIONAL FOREST: Caribou

STATE/COUNTY: Idaho, Caribou/Bear Lake

ACREAGE (GROSS): 30,560 ACREAGE (NET): $30,260100 \mathrm{~N} / \mathrm{G}: 99$ LATITUDE: $42^{\circ} 36^{\prime}$ LONGITUDE: $111^{\circ} 19^{\prime}$

INDIVIDUAL TRACT RESOURCE RATINGS

OIL AND GAS

IIRAN TIIM

COAL

GEOTHERMAL

CRITICAL MINERALS

UVEKALL KAIING

(WEIGHTED)
ORNL USFS DOE USGS

$4 / 3 \quad 4 \quad 4$

$? / 2$

$1 / 3$

$3 / 2$

$4 / 4$

4
REMARKS

Stratigraphic and structural traps compounded by Lhrusting; similar to Canadian Rockies Foothills Belt

NAMES OF CRITICAL MINERALS PRESENT: $P(U, V, F, Z n, C d, C r)$

COMMENTARY AND SUMMARY: Several major and several lesser oil and/or gas fields are located in the southern part of the Absaroka Belt in Wyoming and Utah. Most production is from Jurassic-Triassic reservoirs, but more recent deeper discoveries are in Ujper Paleozoic rocks (Phosphoria) and even more recently in Lower Paleozoic rocks. The Rocky Mountain 0 il and Gas Association estimates that Rare II tracts in the Absaroka belt contain nearly 3.3 billion barrels of oil and over 12.5 trillion cubic feet of gas. The major part of the Southeast Idaho phosphate resource is in this thrust belt, with much of $i t$ in the Rare II tracts. Not only are the phosphate rock resources important for the phosphorus, but there is a significant near-future potential for vanadium, uranium by-product production. The Mt. Pisgah gold district in Bonneville County may have significant potential for Carlin-type gold deposits (Rare II tracts 04160, 04161, and 04162). DOE, critical corridor R-46 low acreage conflict.

GEOLOGY: Absaroka thrust belt (includes terrain westward to surface trace of the Paris-Bannock thrust complex). Includes (as secondary structures) the Crawford, Meade, Medicine Lodge, Sheep Mountain, Skyline, and many smaller thrust faults. Rocks exposed at the surface include sedimentary rocks from Cambrian to Tertiary in age along with some Tertiary and Quaternary volcanics. Several small igneous intrusions of Tertiary Age have been mapped in the Idaho part of the Absaroka Belt, chiefly in the vicinity of the Mt. Pisgah gold district.

REFERENCE/CITATION: USFS, 1978, RARE II DES, ID, UT, and WY Suppls.; DOE, 1978, Energy Res. Assessments of RARE II Lands; DOE, 1978, Energy Res. Assessments, of Ten Alternatives-RARE II Lands; Powers, 1977, WGA Gdbk 29; Blackstone, 1978, Tectonic map of the Overthrust Be1t: WGS; RMOGA, 1978, Estimates of Undiscovered Recoverable Hydrocarbon Resources (RARE-II); White and Williams, 1975, USGS Circ. 726; NOAA, 1977, Geothermal Energy Resources of the Western U.S.; USGS, 1945, Min. Res. Mo. Valley Region, Pts. 1,2,3; ERDA, 1976, NURE-Prelim. Rpt.; Armstrong and Oriel, 1965, AAPG Bul1., v. 43; British Sulfur Corp., Ltd., 1964, A World Survey of Phosphate Deposits: Woodalls Ltd. (Printers), London; Gulbrandsen, 1966, Geochim. Cosmochim. Acta, v. 3, p. 769-778; Brobst and Pratt, 1973, USGS Prof. Paper 820; Worl and 0thers, 1974, USGS MR-60; Kinkel and Peterson, 1962, USGS MR-13; RMAG, 1972, Geologic Atlas of the Rocky Mountain Region: Denver, C0; Bond and Others, 1978, Geologic Map of Idaho: IBMG; Ross, C.P., 1941, IBMG Pamph. 57, pt. 111; Mansfield, 1927, USGS Prof. Paper 152; Leonard and Others, 1978, USGS OFR 78-360; USGS, 1964, Mineral and Water Resources of Idaho: 88th U.S. Congress; Vine, 1959, USGS Bul1. 1055-1. 
ENERGY AND MINERAL RESOURCE EVALUATION - RARE II TRACTS.

TRACT N0: 04166

TRACT NAME: Sage Creek

ECOREG: 3112

WAR: 18

NATIONAL FOREST: Caribou

STATE/COUNTY: Idaho, Caribou

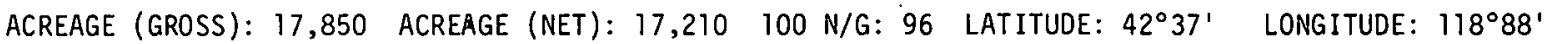

INDIVIDUAL TRACT

RESOURCE RATINGS

$\begin{array}{lll}\text { ORNL } & \frac{\text { USFS }}{4 / 3} & \frac{\text { DOE }}{4}\end{array}$

REMARKS

$\begin{array}{llll}\text { OIL AND GAS } & 4 / 3 & 4 & 4 \\ \text { URANIUM } & 2 / 2 & 1 & 1 \\ \text { COAL } & 1 / 3 & 1 & 1 \\ \begin{array}{l}\text { GEOTHERMAL } \\ \text { CRITICAL MINERALS }\end{array} & 4 / 4 & 4 & \\ \begin{array}{l}\text { OVERALL RATING } \\ \text { (WEIGHTED) }\end{array} & 3^{+} & & 4 .\end{array}$

Stratigraphic and structural traps compounded by thrusting; similar to Canadian Rockies Foothills Beit

NAMES OF CRITICAL MINERALS PRESENT: $\mathrm{P}(\mathrm{U}, \mathrm{V}, \mathrm{F}, \mathrm{Zn}, \mathrm{Cd}, \mathrm{Cr})$

COMMENTARY AND SUMMARY: Several major and several lesser oil and/or gas fields are located in the southern part of the Absaroka Belt in Wyoming and Utah. Most production is from Jurassic-Triassic reservoirs, but more recent deeper discoveries are in. Upper Paleozoic rocks (Phosphoria) and even more recently in Lower Paleozoic rocks. The Rocky Mountain Oil and Gas Association estimates that Rare II tracts in the Absaroka belt contain nearly 3.3 billion barrels of oil and over 1.2 .5 trillion cubic feet of gas. The major part of the Southeast Idaho phosphate resource is in this thrust belt, with much of it in the Rare II tracts. Not only are the phosphate rock resources important for the phosphorus, but there is a significant near-future potential for vanadium, uranium by-product production. The Mt. Pisgah gold district in Bonneville County may have significant potential for Carlin-type gold deposits (Rare II tracts 04160, 04161, and 01162). D0E, moderate corridor R-45 conflict.

GEOLOGY: Absaroka thrust belt (includes terrain westward to surface trace of the Paris-Bannock thrust complex). Includes (as secondary structures) the Crawford, Meade, Medicine Lodge, Sheep Mountain, Skyline, and many smaller thrust faults. Rocks exposed at the surface include sedimentary rocks from Cambrian to Tertiary in age along with some Tertiary and Quaternary volcanics. Several small igneous intrusions of Tertiary Age have been mapped in the Idaho part of the Absaroka Belt, chiefly in the vicinity of the Mt. Pisgah gold district.

REFERENCE/CITATION: USFS, 1978, RARE II DES, ID, UT, and WY Suppls.; D0E, 1978, Energy Res. Assessments of RARE II Lands; DOE, 1978, Energy Res. Assessments, of Ten Alternatives-RARE II Lands; Powers, 1977, WGA Gdbk 29; Blackstone, 1978, Tectonic map of the Overthrust Belt: WGS; RMOGA, 1978, Estimates of Undiscovered Recoverable Hydrocarbon Resources (RARE-II); White and Williams, ig75, USGS Circ. 726; NOAA, 1977, Geothermal Energy Resources of the Western U.S.; USGS, 1945, Min. Res. Mo. Valley Region, Pts. 1,2,3; ERDA, 1976, NURE-Prelim. Rpt.; Armstrong and Oriel, 1965, AAPG Bull., v. 43; British Sulfur Corp., Ltd., 1964, A World Survey of Phosphate Deposits: Woodalls Ltd. (Printers), London; Gulbrandsen, 1966, Geochim. Cosmochim. Acta, v. 3, p. 769-778; Brobst and Pratt, 1973, USGS Prof. Paper 820; Worl and Others, 1974, USGS MR-60; Kinkel and Peterson, 1962, USGS MR-13; RMAG, 1972, Geologic Atlas of the Rocky Mountain Region: Denver, CO; Bond and Others, 1978, Geologic Map of Idaho: IBMG; Ross, C.P., 1941, IBMG Pamph. 57, pt. 111; Mansfield, 1927, USGS Prof. Paper 152; Leonard and Others, 1978, USGS OFR 78-360; USGS, 1964, Mineral and Water Resources of Idaho: 88th U.S. Congress; Vine, 1959, USGS Bul1. 1055-1. 
ENERGY AND MINERAL RESOURCE EVALUATION - RARE II TRACTS

TRACT NO: 04167

NATIONAL FOREST: Caribou
TRACT NAME: Meade Peak

ECOREG: 3112

WAR: 21

ACREAGE (GROSS): 43,520 ACREAGE (NET): $42,160 \quad 100 \mathrm{~N} / \mathrm{G}: 97$ LATITUDE: $42^{\circ} 27^{\prime}$ LONGITUDE: $111^{\circ} 12^{\prime}$

INDIVIDUAL TRACT

RESOURCE RATINGS

UIL ANU GAS

$\underline{\text { ORNL }}$

$4 / 3$

$\underline{\text { USFS }}$

1

$\underline{\mathrm{DOE}}$

$\underline{\text { USGS }}$

4

IIRAN IIIM

COAL

GEOTHERMAL

CRITICAL MINERALS

$2 / 3$

1

$1 / 3$

1

1

$3 / 2$

1

$4 / 4$

4

OVERALL RATING

(WEIGHTED)
4
STATE/COUNTY: Idaho, Caribou/Bear Lake

NAMES OF CRITICAL MINERALS PRESENT: $P(U, V, F, Z n, C d, C r)$

COMMENTARY AND SUMMARY: Several major and several lesser oil and/or gas fields are located in the southern part of the Absaroka Belt in Wyoming and Utah. Most production is from Jurassic-Triassic reservoirs, but more recent deeper discoveries are in Upper Paleozoic rocks (Phosphoria) and even more recently in Lower Paleozoic rocks. The Rocky Mounta in Dil and Gas Association estimates that Rare II tracts in the Absaroka belt contain nearly 3.3 billion barrels of oil and over 12.5 trillion cubic feet of gas. The major part of the Southeast Idaho phosphate resource is in this thrust belt, with much of it in the Rare II tracts. Not only are the phosphate ror.k resnurces important for the phosphorus, but there is a significant near-future potential for vanadium, uranium by-produrt production. The Mt. Hisgah gold district in Bonneville County may have significant potential for Carlin-type gold deposits (Rare II tracts 04160, 04161, and 04162). D0E, critical corridor R-46 conflict (low acreage).

GEOLOGY: Absaroka thrust belt (includes terrain westward to surface trace of the Paris-Bannock thrust complex). Includes (as secondary structures) the Crawford, Meade, Medicine Lodge, Sheep Mountain, Skyline, and many smaller thrust faults. Rocks exposed at the surface include sedimentary rocks from Cambrian to Tertiary in age along with some Tertiary and Quaternary volcanics. Several small igneous intrusions of Tertiary Age have been mapped in the Idaho part of the Absaroka Belt, chiefly in the vicinity of the Mt. Pisgah gold district.

REFERENCE/CITATION: USFS, 1978, RARE II DES, ID, UT, and WY Suppls.; DOE, 1978, Energy Res. Assessments of RARE II Lands; DOE, 1978. Energy Res. Assessments, of Ten Alternatives-RARE II Lands; Powers, 1977, WGA GdbK 29; Blackstone, 1978, Tectonic map of the Overthrust Be1t: WGS; RMOGA, 1978, Estimates of Undiscovered Recoverable Hydrocarbon Resources (RARE-II); White and Williams, 1975, USGS Circ. 726; NOAA, 1977, Geothermal Energy Resources of the Western U.S.; USGS, 1945, Min. Res. Mo. Valley Region, Pts. 1,2,3; ERDA, 1976, NURE-Prelim. Rpt.; Armstrong and Oriel, 1965, AAPG Bull., v. 43; British Sulfur Corp., Ltd., 1964, A World Survey of Phosphate Deposits: Woodal1s Ltd. (Printers), London; Gulbrandsen, 1966, Geochim. Cosmochim. Acta, v. 3, p. 769-778; Brobst and Pratt, 1973, USGS Prof. Paper 820; Worl and Others, 1974, USGS MR-60; Kinkel and Peterson, 1962, USGS MR-13; RMAG, 1972, Geologic Atlas of the Rocky Mountain Region: Denver, C0; Bond and Others, 1978, Geologic Map of Idaho: IBMG; Ross, C.P., 1941, IBMG Pamph. 57, pt. 111; Mansfield, 1927, USGS Prof. Pap.er 152; Leonard and 0thers, 1978, USGS OFR 78-360; USGS, 1964, Mineral and Water Resources of Idaho: 88th U.S. Congress; Vine, 1959, USGS Bul1. 1055-1. 
ENERGY AND MINERAL RESOURCE EVALUATION - RARE II TRACTS

TRACT N0: 04168

TRACT NAME: Hell Hole

ECOREG: 3112

WAR: 15

NATIONAL FOREST: Caribou

STATE/COUNTY: Idaho, Bear Lake

ACREAGE (GROSS): 6,020 ACREAGE (NET): $5,830 \quad 100 \mathrm{~N} / \mathrm{G}: 97$ LATITUDE: $42^{\circ} 19^{\prime}$ LONGITUDE: $111^{\circ} 10^{\prime}$

INDIVIDUAL TRACT RESOURCE RATINGS

OIL AND GAS

URANIUM

COAL

GEOTHERMAL

CRITICAL MINERALS

OVERALL RATING

(WEIGHTED)

\begin{tabular}{|c|c|c|}
\hline ORNL & USFS & $\underline{D O E}$ \\
\hline $4 / 2$ & 4 & 4 \\
\hline $3 / 1$ & 1 & 1 \\
\hline $1 / 4$ & 1 & 1 \\
\hline $2 / 2$ & 1 & \\
\hline $4 / 4$ & 1 & \\
\hline $3^{+}$ & & 4 \\
\hline
\end{tabular}

\section{REMARKS}

Stratigraphic and structural traps compounded by thrusting; similar to Canadian Rockies Foothills Belt

Copper - red bed type

NAMES OF CRITICAL MINERALS PRESENT: $\mathrm{P}(\mathrm{U}, \mathrm{V}, \mathrm{F}, \mathrm{Zn}, \mathrm{Cd}, \mathrm{Cr}) ; \mathrm{Cu}$

COMMENTARY AND SUMMARY: Several major and several lesser oil and/or gas fields are located in the southern part of the Absaroka Belt in Wyoming and Utah. Most production is from Jurassic-Triassic reservoirs, but more recent deeper discoveries are in Upper Paleozoic rocks (Phosphoria) and even more recently in Lower Paleozoic rocks. The Rocky Mountain 0i] and Gas Association estimates that Rare II tracts in the Absaroka belt contain nearly 3.3 billion barrels of oil and over 12.5 trillion cubic feet of gas. The major part of the Southeast Idaho phosphate resource is in this thrust belt, with much of it in the Rare II tracts. Not only are the phosphate rock resources important for the phosphorus, but there is a significant near-future potential for vanadium, uranium by-product production. The Mt. Pisgah gold district in Bonneville County may have significant potential for Carlin-type gold deposits (Rare II tracts 04160, 04161, and 04i62).

GEOLOGY: Absaroka thrust belt (includes terrain westward to surface trace of the Paris-Bannock thrust complex). Includes (as secondary structures) the Crawford, Meade, Medicine Lodge, Sheep Mountain, Skyline, and many smaller thrust faults. Rocks exposed at the surface include sedimentary rocks from Cambrian to Tertiary in age along with some Tertiary and Quaternary volcanics. Several small igneous intrusions of Tertiary Age have been mapped in the Idaho part of the Absaroka Belt, chiefly in the vicinity of the Mt. Pisgah gold district.

REFERENCE/CITATION: USFS, 1978, RARE II DES, ID, UT, and WY Suppls.; D0E, 1978, Energy Res. Assessments of RARE II Lands; D0E, 1978, Energy Res. Assessments, of Ten Alternatives-RARE II Lands; Powers, 1977, WGA Gdbk 29; Blackstone, 1.978, Tectonic map of the Overthrust Belt: WGS; RMOGA, 1978, Estimates of Undiscovered Recoverable Hydrocarbon Resources (RARE-II); White and Williams, 1975, USGS Circ. 726; NOAA, 1977, Geothermal Energy Resources of the Western U.S.; USGS, 1945, Min. Res. Mo. Valley Region, Pts. 1,2,3; ERDA, 1976, NURE-Prelim. Rpt.; Armstrong and Oriel, 1965, AAPG Bull., v. 43; British Sulfur Corp., Ltd., 1964, A World Survey of Phosphate Deposits: Woodal1s Ltd. (Printers), London; Gulbrandsen, 1966, Geochim. Cosmochim. Acta, v. 3, p. 769-778; Brobst and Pratt, 1973, USGS Prof. Paper 820; Worl and Others, 1974, USGS MR-60; Kinkel and Peterson, 1962, USGS MR-13; RMAG, 1972, Geologic Atlas of the Rocky Mountain Region: Denver, CO; Bond and Others, 1978, Geologic Map of Idaho: IBMG; Ross, C.P., 1941, IBMG Pamph. 57, pt. 111; Mansfield, 1927, USGS Prof. Paper 152; Leonard and 0thers, 1978, USGS OFR 78-360; USGS, 1964, Mineral and Water Resources of Idaho: 88th U.S. Congress; Vine, 1959, USGS Bu11. 1055-1. 
NATIONAL FOREST: Caribou

ACREAGE (GROSS): 5,090
STATE/COUNTY: Idaho, Bear Lake ACREAGE (NET): 5,090

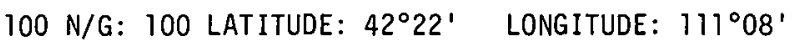

INDIVIDUAL TRACT
RESOURCE RATINGS

\begin{tabular}{|c|c|c|c|}
\hline RESOURCE RATINGS & $\underline{\mathrm{ORNL}}$ & USFS & $\underline{\mathrm{DOE}}$ \\
\hline ח ATI, AṆ GAS & $4 / 3$ & 4 & 4 \\
\hline URAN IUM & $3 / 1$ & 1 & 1 \\
\hline COAL & $1 / 3$ & i & 1 \\
\hline GEOTHERMAL & $3 / 2$ & 1 & \\
\hline CRITICAL MINERALS & $3 / 2$ & 1 & \\
\hline $\begin{array}{l}\text { OVERALI. RAT ING } \\
\text { (WEIGHTED) }\end{array}$ & 3 & & 4 \\
\hline
\end{tabular}

\section{REMARKS}

Stratigraphic and structural traps com-
pounded by thrueting; eimilar to Canadian Rockies Foothills Belt

Copper - red bed type

NAMES OF CRITICAL MINERALS PRESENT: $\mathrm{CU}$

COMMENTARY AND SUMMARY: Several major and several lesser oil and/or gas fields are located in the southern part of the Absaroka Belt in Wyoming and Utah. Most production is from Jurassic-Triassic reservoirs, but more recent deeper discoveries are in Upper Paleozoic rocks (Phosphoria) and even more recently in Lower Paleozoic rocks. The Rocky Mountain 0il and Gas Association estimates that Rare II tracts in the Absaroka belt contain nearly 3.3 billion barrels of oil and over 12.5 trillion cubic feet. of gas. The major part of the Southeast Idaho phosphate resource is in this thrust belt, with much of $i t$ in the Rare II tracts. Not only are the phosphate rock resources important for the phosphorus, but there is a significant near-future potential for vanadium, uranium by-product production. The Mt. Pisgah gold district in Bonneville County may have significant potential for Carlin-type gold deposits (Rare II tracts 04160, 04161 , and 04162). DOE, moderate corridor (R-45) conflict.

GEOLOGY: Absaroka thrust belt (includes terrain westward to surface trace of the Paris-Bannock thrust complex). Includes (as secondary structures) the Crawford, Meade, Medicine Lodge, Sheep Mountain, Skyline, and many smaller thrust faults. Rocks exposed at the surface include sedimentary rocks from Cambrian to Tertiary in age along with some Tertiary and Quaternary volcanics. Several small igneous intrusions of Tertiary Age have been mapped in the Idaho part of the Absaroka Belt, chiefly in the vicinity of the Mt. Pisgah gold district.

REFERENCE/CITATION: USFS, 1978, RARE II DES, ID, UT, and WY Suppls.; D0E, 1978, Energy Res. Assessments of RARE II Lands; DOE, 1978, Energy Res. Assessments, of Ten Aiternatives-RARE II Lands; Powers, 1977, WGA lidbK 29 ; Blackstone, 19\%8, Tectonic map of the Overthrust Be1t: WGS; RMOGA, 1978, Estimates of Undiscovered Recoverable Hydrocarbon Resources (RARE-II); White and Williams, 1975, USGS Circ. 726; NOAA, 1977, Geothermal Energy Resources of the Western U.S.; USGS, 1945, Min. Res. Mo. Valley Region, Pts. 1,2,3; ERDA, 1976, NURE-Prelim. Rpt.; Armstrong and Orie1, 1965, AAPG Bul1., v. 43; British Sulfur Corp., Ltd., 1964, A World Survey of Phosphate Deposits: Woodalls Ltd. (Printers), London; Gulbrandsen, 1966, Geochim. Cosmochim. Acta, v. 3, p. 769-778; Brobst and Pratt, 1973, USGS Prof. Paper 820; Worl and Others, 1974, USGS MR-60; Kinkel and Peterson, 1962, USGS MR-13; RMAG, 1972, Geologic Atlas of the Rocky Mounta in Region: Denver, C0; Bond and Others, 1978, Geologic Map of Idaho: IBMG; Ross, C.P., 1941, IBMG Pamph. 57, pt. 111; Mansfield, 1927, USGS Prof. Paper 152; Leonard and 0thers, 1978, USGS OFR 78-360; USGS, 1964, Mineral and Water Resources of Idaho: 88th U.S. Congress; Vine, 1959, USGS Bull. 1055-1. 
ENERGY AND MINERAL RESOURCE EVALUATION - RARE II TRACTS

TRACT N0: 04170

NATIONAL FOREST: Caribou
TRACT NAME: Red Mountain

ECOREG: 3112

WAR: 19

ACREAGE (GROSS): 13,800 ACREAGE (NET): 13,800 $100 \mathrm{~N} / \mathrm{G}: 100$ LATITUDE: $42^{\circ} 27^{\prime}$ LONGITUDE: $111^{\circ} 07^{\prime}$

INDIVIDUAL TRACT

RESOURCE RATINGS

UIL AND GAS

URANIUM

COAL

GEOTHERMAL

CRITICAL MINERALS

OVERALL RATING

(WEIGHTED)

\begin{tabular}{|c|c|c|}
\hline ORNL & USFS & $\underline{\mathrm{DOE}}$ \\
\hline $4 / 3$ & 4 & 4 \\
\hline
\end{tabular}

1

1

$1 / 3 \quad 1 \quad 1$

$3 / 2 \quad 1$

$3 / 2 \quad 1$

$3^{+}$

STATE/COUNTY: Idaho, Bear Lake/Caribou

\section{REMARKS}

Stratigraphic and structural traps compounded by thrusting; similar to Canadian Rockies Foothills Belt

Copper - red bed type deposits

NAMES OF CRITICAL MINERALS PRESENT: CU

COMMENTARY AND SUMMARY: Several major and several lesser oil and/or gas fields are located in the southern part of the Absaroka Belt in Wyoming and Utah. Most production is from Jurassic-Triassic reservoirs, but more recent deeper discoveries are in Upper Paleozoic rocks (Phosphoria) and even more recently in Lower Paleozoic rocks. The Rocky Mountain Oil and Gas Association estimates that Rare II tracts in the Absaroka belt contain nearly 3.3 billion barrels of oil and over 12.5 trillion cubic feet of gas. The major part of the Southeast Idaho phosphate resource is in this thrust belt, with much of it in the Rare II tracts. Not only are the phosphate rock resources important for the phosphorus, but there is a significant near-future potential for vanadium, uranium by-product production. The Mt. Pisgah gold district in Bonneville County may have significant potential for Carlin-type gold deposits (Rare II tracts.04160,04161, and 04162). DOE, moderate corridor conflict (R-45).

GEOLOGY: Absaroka thrust belt (includes terrain westward to surface trace of the Paris-Bannock thrust complex). Includes (as secondary structures) the Crawford, Meade, Medicine Lodge, Sheep Mountain, Skyline, and many smaller thrust faults. Rocks exposed at the surface include sedimentary rocks from Cambrian to Tertiary in age along with some Tertiary and Quaternary volcanics. Several small igneous intrusions of Tertiary Age have been mapped in the Idaho part of the Absaroka Belt, chiefly in the vicinit.y of the Mt. Pisgah gold district.

REFERENCE/CITATION: USFS, 1978, RARE II DES, ID, UT, and WY Suppls.; DOE, 1978, Energy Res. Assessments of RARE II Lands; DOE, 1978, Energy Res. Assessments, of Ten Alternatives-RARE II Lands; Powers, 1977, WGA Gdbk 29; Blackstone, 1978, Tectonic map of the Overthrust Belt: WGS; RMOGA, 1978, Estimates of Undiscovered Recoverable Hydrocarbon Resources (RARE-II); White and Williams, 1975, USGS Circ. 726; NOAA, 1977, Geothermal Energy Resources of the Western U.S.; USGS, 1945, Min. Res. Mo. Valley Region, Pts. 1,2,3; ERDA, 1976, NURE-Prelim. Rpt.; Armstrong and Oriel, 1965, AAPG Bul1.., v. 43; British Sulfur Corp., Ltd., 1964, A World Survey of Phosphate Deposits: Woodalls Ltd. (Printers), London; Gulbrandsen, 1966, Geochim. Cosmochim. Acta, v. 3, p. 769-778; Brobst and Pratt, 1973, USGS Prof. Paper 820; Worl and Others, 1974, USGS MR-60; Kinkel and Peterson, 1962, USGS MR-13; RMAG, 1972, Geologic Atlas of the Rocky Mountain Region: Denver, C0; Bond and Others, 1978, Geologic Map of Idaho: IBMG; Ross, C.P., 1941, IBMG Pamph. 57, pt. 111; Mansfield, 1927, USGS Prof. Paper 152; Leonard and 0thers, 1978, USGS OFR 78-360; USGS, 1964, Mineral and Water Resources of Idaho: 88th U.S. Congress; Vine, 1959, USGS BuIl. $1055-1$. 
ENERGY AND MINERAL RESOURCE EVALUATION - RARE II TRACTS

TRACT N0: 04171

NATIONAL FOREST: Caribou

ACREAGE (GROSS): 23,750

TRACT NAME: Soda Point

ECOREG: 3112

WAR: 19

STATE/COUNTY: Idaho, Caribou/Bear Lake

\begin{tabular}{|c|c|c|c|c|}
\hline $\begin{array}{l}\text { INDIVIDUAL TRACT } \\
\text { RESOUR.CE RATINGS }\end{array}$ & $\underline{\mathrm{nRNI}}$ & $\underline{\text { IISFSS }}$ & $\underline{\mathrm{DOE}}$ & USGS \\
\hline OIL AND GAS & $4 / 2$ & 4 & 3 & \\
\hline URAN IUM & $2 / 1$ & 1 & 1 & \\
\hline COAL & $1 / 4$ & 1 & 1 & \\
\hline GEOTHERMAL & $2 / 2$ & 1 & & \\
\hline C.RITICAI. MINFRAI_S & $2 / 1$ & 1 & & \\
\hline $\begin{array}{l}\text { OVERALL RATING } \\
\text { (WEIGHTED) }\end{array}$ & $2^{-}$ & & 3 & \\
\hline
\end{tabular}

NAMES OF CRITICAL MINERALS PRESENT: Base and precious metals?

COMMENTARY AND SUMMARY: Petroleum exploration has not been as intensive in the Paris-Bannock thrust belt as in the more easterly thrust structures; however, several holes showing some oil and gas have been completed in the past. The Rocky Mounta1n 011 and Gas Associalion estimates that over 300 million barrels of oil and approximately three trillion cubic feet of gas occur in Rare II tracts in this belt. Phosphate resources are minor in comparison with the more easterly belts. Some potential for disseminated gold and base metals in the Precambrian and Lower Paleozoic strata is also present. DOE, 2 for minor hydro conflict.

GEOLOGY: Paris-Bannock thrust belt (includes terrain between Paris-Bannock fault on east and the Wasatch fauit and its northward projection on the west). The Wasatch fault is the major east boundary fault of the Basin and Range structural province and is generally normal in character, usually having a steep westward dip. Bedrock includes strata from the younger Precambrian, all Paleozoic systems, and Tertiary and Quaternary deposits. Tertiary and Quaternary volcanic rocks and similar age gravels locally cover the older rocks and structures.

REFERENCE/CITATION: USFS, 1978, RARE II DES, ID, UT, and WY Suppls.; DOE, 1978, Energy Res. Assessments of RARE II Lands; DOE, 1978, Energy Res. Assessments, of Ten Alternatives-RARE 11 Lands; Powers, 1977, WGA Gdbk 29; Blackstone, 1978, Tectonic map of the Overthrust. Belt: WGS; RMOGA, 1978, Estimates of Undiscovered Recoverable Hydrocarbon Kesources (KAKE-II); Wh1te and Will tams, 1975, USGS CIrc. 726 ; NOAA, 1977, Geothermal Energy Resources of the Western U.S.; USGS, 1945, Min. Res. Mo. Valley Region, Pts. 1,2,3; ERDA, 1976, NURE-Prelim. Rpt.; Armstrong and Oriel, 1965, AAPG Bul1., v. 43; British Sulfur Corp., Ltd., 1964, A World Survey of Phosphate Deposits: Woodalls Ltd. (Printers), London; Gulbrandsen, 1966, Geochim. Cosmochim. Acta, v. 3, p. 769-778; Brobst and Pratt, 1973, USGS Prof. Paper 820; Wor 1 and 0thers, 1974, USGS MR-60; Kinke1 and Peterson, 1962, USGS MR-13; RMAG, 1972, Geologic Atlas of the Rocky Mountain Region: Denver, CO; Bond and Others, 1978, Geologic Map of Idaho: IBMG; Ross, C.P., 1941, IBMG Pamph. 57, pt. 111; Mansfield, 1927, USGS Prof. Paper 152; Leonard and 0thers, 1978, USGS OFR 78-360; USGS, 1964, Mineral and Water Resources of Idaho: 88th U.S. Congress; Vine, 1959, USGS Bu11. 1055-1. 
ENERGY AND MINERAL RESOURCE EVALUATION - RARE II TRACTS

TRACT NO: 04172

NATIONAL FOREST: Caribou
TRACT NAME: Sherman Peak

ECOREG: 3112

WAR: 19

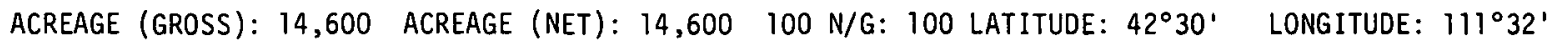

\begin{tabular}{|c|c|c|c|c|}
\hline $\begin{array}{l}\text { INDIVIUUAL TKACT } \\
\text { RESOURCE RAT INGS } \\
\end{array}$ & ORNL & $\underline{\text { USFS }}$ & $\underline{D O E}$ & $\underline{\text { USGS }}$ \\
\hline OIL AND GAS & $4 / 2$ & 4 & 3 & \\
\hline URANIUM & $2 / 1$ & 1 & 1 & \\
\hline COAL & $1 / 4$ & 1 & 1 & \\
\hline GEOTHERMAL & $2 / 2$ & 1 & & \\
\hline CRITICAL MINERALS & $2 / 2$ & 1 & . & \\
\hline $\begin{array}{l}\text { OVERALL RATING } \\
\text { (WEIGHTED) }\end{array}$ & $2-$ & & 3 & \\
\hline
\end{tabular}

STATE/COUNTY: Idaho, Bear Lake

NAMES OF CRITICAL MINERALS PRESENT: Base metals

COMMENTARY AND SUMMARY: Petroleum exploration has not been as intensive in the Paris-Bannock thrust belt as in the more easterly thrust structures; however, several holes showing some oil and gas have been completed in the past. The Rocky Mountain $0 i 1$ and Gas Association estimates that over 300 million barrels of oil and approximately three trillion cubic feet of gas occur in Rare II tracts in this belt. Phosphate resources are minor in comparison with the more easterly belts. Some potential for disseminated gold and base metals in the Precambrian and Lower Paleozoic strata is also present. DOE, high conflict R-47 corridor.

GEOLOGY: Paris-Bannock thrust belt (includes terrain between Paris-Bannock fault on east and the Wasatch fault and its northward projection on. the west). The Wasatch fault is the major east boundary fault of the Basin and Range structural province and is generally normal in character, usually having a steep westward dip. Bedrock includes strata from the younger Precambrian, all Paleozoic systems, and Tertiary and Quaternary deposits. Tertiary and Quaternary volcanic rocks and similar age gravels locally cover the older rocks and structures.

REFERENCE/CITATION: USFS, 1978, RARE II DES, ID, UT, and WY Suppls.; D0E, 1978, Energy Res. Assessments of RARE II Lands; D0E, 1978, Energy Res. Assessments, of Ten Alternatives-RARE II Lands; Powers, 1977, WGA Gdbk 29; Blackstone, 1978, Tectonic map of the Overthrust Belt: WGS; RMOGA, 1978, Estimates of Undiscovered Recoverable Hydrocarbon Resources (RARE-II); White and Williams, 1975, USGS Circ. 726; NOAA, 1977, Geothermal Energy Resources of the Western U.S.; USGS, 1945, Min. Res. Mo. Valley Region, Pts. 1,2,3; ERDA, 1976, NURE-Prelim. Rpt.; Armstrong and Oriel, 1965, AAPG Bull., v. 43; British Sulfur Corp., Ltd., 1964, A World Survey of Phosphate Deposits: Woodails Ltd. (Printers), London; Gulbrandsen, 1966, Geochim. Cosmochim. Acta, v. 3, p. 769-778; Brobst and Pratt, 1973, USGS Prof. Paper 820; Worl and Others, 1974, USGS MR-60; Kinkel and Peterson, 1962, USGS MR-13; RMAG, 1972, Geologic Atlas of the Rocky Mountain Region: Denver, CO; Bond and 0thers, 1978, Geologic Map of Idaho: IBMG; Ross, C.P., 1941, IBMG Pamph. 57, pt. 111; Mansfie1d, 1927, USGS Prof. Paper 152; Leonard and 0thers, 1978, USGS OFR 78-360; USGS, 1964, Mineral and Water Resources of Idaho: 88th U.S. Congress; Vine, I959, USGS Bul1. 1055-1. 
ENERGY AND MINERAL RESOURCE EVALUATION - RARE II TRACTS

TRACT NO: 04173

TRACT NAME: Stauffer Creek

ECOREG: 3112

WAR: 20

NATIONAL FOREST: Caribou

ACREAGE (GROSS): 7,860
SIATE/COUNTY: Idaho, Bear Lake

ACREAGE (NET): $7,860 \quad 100 \mathrm{~N} / \mathrm{G}: 100$ LATITUDE: $42^{\circ} 26^{\prime}$ LONGITUDE: $111^{\circ} 31^{\prime}$
INDIVIDUAL TRACT RESOURCE RATINGS

OIL AND GAS

URANIUM

COAL

GEOTHERMAL

CRITICAL MINERALS

OVERALL RATING

(WEIGHTED) $\underline{\text { ORNL }} \underline{\text { USFS }} \underline{\text { DOE }} \underline{\text { USGS }}$

$4 / 1 \quad 4 \quad 3$

$2 / 1$

$1 / 4$

$2 / 2$

$2 / 2$

$2^{-}$
REMARKS

Stratigraphic and structural traps compounded by thrusting; similar to Canadian Rockies Foothills Belt

NAMES OF CRITICAL MINERALS PRESENT: Base metals

COMMENTARY AND SUMMARY: Petroleum exploration has not been as intensive in the Paris-Bannock thrust belt as in the more easterly thrust structures; however, several holes showing some oil and gas have been completed in the past. The Rocky Mountain $0 i l$ and Gas Association estimates that over 300 million barrels of oil and approximately three trillion cubic feet of gas occur in Rare II tracts in this belt. Phosphate resources are minor in comparison with the more easterly belts. Some potential for disseminated gold and base metals in the Precambrian and Lower Paleozoic strata is also present.

GEOLOGY: Paris-Bannock thrust belt (includes terrain between Paris-Bannock fault on east and the wasatch fault and its northward projection on the west). The Wasatch fault is the major east boundary fault of the Basin and Range structural province and is generally normal in character, usually having a steep westward dip. Bedrock includes strata from the younger Precambrian, all Paleozoic systems, and Tertiary and Quaternary deposits. Tertiary and Quaternary volcanic rocks and similar age gravels locally cover the older rocks and structures.

REFERENCE/CITÁTION: USFS, 1978, RARE II DES, ID, UT, and WY Suppls.; DOE, 1978, Energy Res. Assessments of RARE II Lands; DOE, 1978, Energy Res. Assessments, of Ten Alternatives-RARE II Lands; Powers, 1977, WGA Gdbk 29; Blackstone, 1978, Tectonic map of the Overthrust Belt: WGS; RMOGA, 1978, Estimates of Undiscovered Recoverable Hydrocarbon Resources (RARE-II); White and Williams, 1975, USGS Circ. 726; NOAA, 1977, Geothermal Energy Resources of the Western U.S.; USGS, 1945, Min. Res. Mo. Valley Region, Pts. 1,2,3; ERDA, 1976, NURE-Prelim. Rpt.; Armstrong and Oriel, 1965, AAPG Bull., v. 43; British Sulfur Corp., Ltd., 1964, A World Survey of Phosphate Deposits: Woodalls Ltd. (Printers), London; Gulbrandsen, 1966, Geochim. Cosmochim. Acta, v. 3, p. 769-778; Brobst and Pratt, 1973, USGS Prof. Paper 820; Worl and 0thers, 1974, USGS MR-60; Kinkel and Peterson, 1962, USGS MR-13; RMAG, 1972, Geologic Atlas of the Rocky Mounta in Region: Denver, CO; Bond and Others, 1978, Geologic Map of Idaho: IBMG; Ross. C.P., 1941, IBMG Pamph. 57, pt. 111; Mansfie1d, 1927. USGS Prof. Paper 152; Leonard and 0thers, 1978, UISGS OFR 78-360; USGS, 1964, Mineral and water Resources of Idaho: 88th U.S. Congress; Vine, 1959, USGS Bul1. 1055-1. 
ENERGY AND MINERAL RESOURCE EVALUATION - RARE II TRACTS

TRACT NO: 04174

NATIONAL FOREST: Caribou
TRACT NAME: Will iams Creek

ECOREG: 3112

WAR: 19

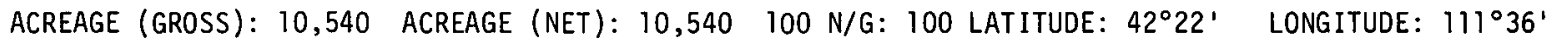

INDIVIDUAL TRACT

RESOURCE RATINGS

OIL AND GAS

$\frac{\text { ORNL }}{4 / 2}$

USFS

DOE

USGS

3

URANIUM

COAL

$2 / 1$

$3 / 1$

$3 / 2$

$2 / 1$

CRITICAL MINERALS

OVERALL RATING

(WEIGHTED)

1

1

4

1

1

NAMES OF CRITICAL MINERALS PRESENT: Base metals, chiefly Pb

COMMENTARY AND SUMMARY: Petroleum exploration has not been as intensive in the Paris-Bannock thrust belt as in the more easterly thrust structures; however, several holes showing some oil and gas have been completed in the past. The Rocky Mountain $0 i l$ and Gas Association estimates that over 300 million barrels of oil and approximately three trillion cubic feet of gas occur in Rare II tracts in this belt. Phosphate resources are minor in comparison with the more easterly belts. Some potential for disseminated gold and base metals in the Precambrian and Lower Paleozoic strata is also present. DOE, moderate conflict, corridor R-48.

GEOLOGY: Paris-Bannock thrust belt (includes terrain between Paris-Bannock fault on east and the Wasatch fault and its northward projection on the west). The Wasatch fault is the major east boundary fault of the Basin and Range structural province and is generally normal in character, usually having a steep westward dip. Bedrock includes strata from the younger Precambrian, all Paleozoic systems, and Tertiary and Quaternary deposits. Tertiary and Quaternary volcanic rocks and similar age gravels locally cover the older rocks and structures.

REFERENCE/CITATION: USFS, 1978, RARE II DES, ID, UT, and WY Suppls.; DOE, 1978, Energy Res. Assessments of RARE II Lands; DOE, 1978, Energy Res. Assessments, of Ten Alternatives-RARE II Lands; Powers, 1977, WGA Gdbk 29; Blackstone, 1978, Tectonic map of the Overthrust Belt: WGS; RMOGA, 1978, Estimates of Undiscovered Recoverable Hydrocarbon Resources (RARE-II); White and Williams, 1975, USGS Circ. 726; NOAA, 1977, Geothermal Energy Resources of the Western U.S.; USGS, 1945, Min. Res. Mo. Valley Region, Pts. 1,2,3; ERDA, 1976, NURE-Prelim. Rpt.; Armstrong and Oriel, 1965, AAPG Bull., v. 43; British Sulfur Corp., Ltd., 1964, A World Survey of Phosphate Deposits: Woodalls Ltd. (Printers), London; Gulbrandsen, 1966, Geochim. Cosmochim. Acta, v. 3, p. 769-778; Brobst and Pratt, 1973, USGS Prof. Paper 820; Worl and Others, 1974, USGS MR-60; Kinkel and Peterson, 1962, USGS MR-13; RMAG, 1972, Geologic Atlas of the Rocky Mountain Region: Denver, C0; Bond and Others, 1978, Geologic Map of Idaho: IBMG; Ross, C.P., 1941, IBMG Pamph. 57, pt. 111; Mansfie1d, 1927, USGS Prof. Paper 152; Leonard and 0thers, 1978, USGS OFR 78-360; USGS, 1964, Mineral and Water Resources of Idaho: 88th U.S. Congress; Vine, 1959, USGS Bul1. 1055-1. 
ENERGY AND MINERAL RESOURCE EVALUATION - RARE II TRACTS

TRACT NO: 04175

NATIONAL FOREST: Caribou

ACREAGE (GROSS): 16,800

ECOREG: 3112

WAR : 20

STATE/COUNTY: Idaho, Bear Lake/Franklin

ACREAGE (NET): $16,800100 \mathrm{~N} / \mathrm{G}: 100$ LATITUDE: $42^{\circ} 18^{\prime} \quad$ LONGITUDE: $111^{\circ} 33^{\prime}$
REMARKS

Stratigraphic and structural traps compounded by thrusting; similar to Canadian Rockies Foothills Belt

\begin{tabular}{|c|c|c|c|c|}
\hline $\begin{array}{l}\text { INDIVIDUAL TRACT } \\
\text { RESOURCE RATINGS }\end{array}$ & $\underline{\text { ORNL }}$ & $\underline{\text { USFS }}$ & $\underline{\mathrm{DOE}}$ & USGS \\
\hline OIL AND GAS & $4 / 2$ & 4 & 3 & \\
\hline URANIUM & $2 / 1$ & 1 & 1 & \\
\hline COAL & $1 / 3$ & 1 & 1 & \\
\hline GEOTHERMAL & $3 / 2$ & 1 & & \\
\hline CRITICAL MINERALS & $2 / 3$ & 1 & & \\
\hline $\begin{array}{l}\text { OVERALL RATING } \\
\text { (WEIGHTED) }\end{array}$ & 2 & & 3 & \\
\hline
\end{tabular}

Hot springs

NAMES OF CRITICAL MINERALS. PRESENT: Metals, chiefly Pb

COMMENTARY AND SUMMARY: Petroleum exploration has not been as intensive in the Paris-Bannock thrust Delt as in the more easterly thrust structures; however, several holes showing some oil and gas have been completed in the past. The. Rocky Mountain 011 and Gas Association estimates that over 300 mil1ion barrels of oil and approximately three trillion cubic feet of gas occur in Rare II tracts in this belt. Phosphate resources are minor in comparison with the more easterly belts. Some potential for disseminated gold and base metals in the Precambrian and Lower Paleozoic strata is also present. DOE, moderate conflict corridor R-48.

GEOLOGY: Paris-Bannock thrust belt (includes terrain between Paris-Bannock fault on east and the Wasatch fault and its northward projection on the west). The Wasatch fault is the major east boundary fault of the Basin and Range structural province and is generally normal in character, usually having a steep westward dip. Bedrock includes strata from the younger Precambrian, all Paleozoic systems, and Tertiary and Quaternary deposits. Tertiary and Quaternary volcanic rocks and similar age gravels locally cover the older rocks and structures.

REFERENCE/CITATION: USFS, 1978, RARE II DES, ID, UT, and WY Suppls.; DOE, 1978, Energy Res. Assessments of RARE II Lands; DOE, 1978, Energy Res. Assessments, of Ten Aiternatives-RARE II Lands; Powers, 1977, WGA Gdbk 29; Blackstone, 1978, Tectonic map of the Overthrust Belt: WGS; RMOGA, 1978, Estimates of Undiscovered Recoverable Hydrocarbon Resources (RARE-II); White and Williams, 1975, USGS Circ. 726 ; NOAA, 1977, Geothermal Energy Resources of the Western U.S.; USGS, 1945, Min. Res. Mo. Valley Region, Pts. 1,2,3; ERDA, 1976, NURE-Prelim. Rpt.; Armstrong and Oriel, 1965, AAPG Bull., v. 43; British Sulfur Corp., Ltd., 1964, A World Survey of Phosphate Deposits: Woodalls Ltd. (Printers), London; Gulbrandsen, 1966, Geochim. Cosmochim. Acta, v. 3, p. 769-778; Brobst and Pratt, 1973. USGS Prof. Paper 820; Worl and Others, 1974, USGS MR-60; Kinke1 and Peterson, 1962, USGS MR-13; RMAG, 1972, Geologic Atlas of the Rocky Mountain Region: Denver, CO; Bond and Others, 1978, Geologic Map of Idaho: IBMG; Ross, C.P., 1941, IBMG Pamph. 57, pt. 111; Mansfield, 1927, USGS Prof. Paper 152; Leonard and 0thers, 1978, USGS OFR 78-360; USGS, 1964, Mineral and Water Resources of Idaho: 88th U.S. Congress; Vine, 1959, USGS Bul1. 1055-1. 
TRACT NO: 04176

NATIONAL FOREST: Caribou

TRACT NAME: Mink Creek

ECOREG: 3112

WAR: 20

STATE/COUNTY: Idaho, Frankl in/Bear Lake

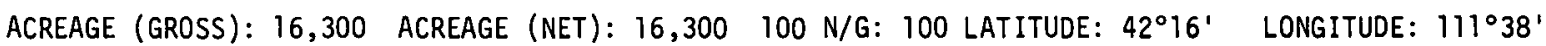

INDIVIDUAL TRACT

RESOURCE RATINGS

ORNL

$\underline{\text { USFS }}$

DOE USGS
OIL AND GAS

$4 / 1$

43

3

URANIUM

$2 / 1$

COAL

$2 / 3$

$3 / 2$

$2 / 2$

2

1

1

1

1

OVERALL RATING

(WEIGHTED)

1
4
1
1

1

Hot springs

\author{
Stratigraphic and structural traps com- \\ pounded by thrusting; similar to Canadian \\ Rockies Foothills Beit
}

Tertiary coal

NAMES OF CRITICAL MINERALS PRESENT: Base metals, chiefly Pb

COMMENTARY AND SUMMARY: Petroleum exploration has not been as intensive in the Paris-Bannock thrust belt as in the more easterly thrust structures; however, several holes showing some oil and gas have been completed in the past. The Rocky Mountain 0il and Gas Association estimates that over $300 \mathrm{million}$ barrels of oil and approximately three trillion cubic feet of gas occur in Rare II tracts in this belt. Phosphate resources are minor in comparison with the more easterly belts. Some potential for disseminated gold and base metals in the Precambrian and Lower Paleozoic strata is also present. DOE, moderate conflict corridor R-48.

GEOLOGY: Paris-Bannock thrust belt (includes terrain between Paris-Bannock fault on east and the Wasatch fault and its northward projection on the west). The Wasatch fault is the major east boundary fault of the Basin and Range structural province and is generally normal in character, usually having a steep westward dip. Bedrock includes strata from the younger Precambrian, all Paleozoic systems, and Tertiary and Quaternary deposits. Tertiary and Quaternary volcanic rocks and similar age gravels locally cover the older rocks and structures.

REFERENCE/CITATION: USFS, 1978, RARE II DES, ID, UT, and WY Suppls.; D0E, 1978, Energy Res. Assessments of RARE II Lands; DOE, 1978, Energy Res. Assessments, of Ten Alternatives-RARE II Lands; Powers, 1977, WGA Gdbk 29; Blackstone, 1978, Tectonic map of the Overthrust Belt: WGS; RMOGA, 1978, Estimates of Undiscovered Recoverable Hydrocarbon Resources (RARE-II); White and Williams, 1975, USGS Circ. 726; NOAA, 1977, Geothermal Energy Resources of the Western U.S.; USGS, 1945, Min. Res. Mo. Valley Region, Pts. 1,2,3; ERDA, 1976, NURE-Prelim. Rpt.; Armstrong and Orie1, 1965, AAPG Bul1., v. 43; British Sulfur Corp., Ltd., 1964, A World Survey of Phosphate Deposits: Woodalis Ltd. (Printers), London; Gulbrandsen, 1966, Geochim. Cosmochim. Acta, v. 3, p. 769-778; Brobst and Pratt, 1973, USGS Prof. Paper 820; Worl and Others, 1974, USGS MR-60; Kinkel and Peterson, 1962, USGS MR-13; RMAG, 1972, Geologic Atlas of the Rocky Mountain Region: Denver, C0; Bond and Others, 1978, Geologic Map of Idaho: IBMG; Ross, C.P., 1941, IBMG Pamph. 57, pt. 111; Mansfield, 1927, USGS Prof. Paper 152; Leonard and 0thers, 1978, USGS OFR 78-360; USGS, 1964, Mineral and Water Resources of Idaho: 88th U.S. Congress; Vine, 1959, USGS Bul1. 1055-1. 
ENERGY AND MINERAL RESOURCE EVALUATION - RARE II TRACTS

TRACT NO: 04177

NATIONAL. FOREST: Caribou
TRACT NAME: Paris Peak

ECOREG: 3112

WAR: 17

STATE/COUNTY: Idaho, Bear Lake

ACREAGE (NET): 9,200

$100 \mathrm{~N} / \mathrm{G}: 100$ LATITUDE: $42^{\circ} 12^{\prime}$ LONGITUDE: $11^{\circ} 32^{\prime}$

\begin{tabular}{|c|c|c|c|c|}
\hline $\begin{array}{l}\text { INDIVIDUAL TRACT } \\
\text { RESOURCE RATINGS } \\
\end{array}$ & $\underline{\text { ORNL }}$ & USFS & $\underline{\mathrm{DOE}}$ & $\underline{\text { USGS }}$ \\
\hline OIL AND GAS & $4 / 7$ & 4 & 3 & \\
\hline URANIUM & $2 / 1$ & 1 & 1 & \\
\hline LUAL & $1 / 3$ & 1 & 1 & \\
\hline GEOTHERMAL & $2 / 2$ & 1 & & \\
\hline CRITICAL MINERAI_S & $2 . / 3$ & 1 & & \\
\hline $\begin{array}{l}\text { OVERALL RATING } \\
\text { (WEIGHTED) }\end{array}$ & $2^{+}$ & & 3 & \\
\hline
\end{tabular}

REMARKS

Stratigraphic and structural traps compounded by thrusting; similar to Canadian Rockies Foothills Belt

NAMES OF CRITICAL MINERALS PRESENT: Metals, chiefly Pb

COMMENTARY AND SUMMARY: Petroleum exploration has not been as intensive in the Paris-Bannock thrust belt as in the more easterly thrust structures; however, several holes showing some oil and gas have been completed in the past. The Rocky Mountain $0 i 1$ and Gas Association estimates that over 300 million barrels of $0 i 1$ and approximately three trillion cubic feet of gas occur in Rare II tracts in this belt. Phosphate resources are minor in comparison with the more easterly belts. Some potential for disseminated gold and base metals in the Precambrian and Lower Paleozoir. strata is also present. DOE, moderate conflict rorridnr $R=\Delta 8$

GEOLOGY: Paris-Bannock thrust belt (includes terrain between Paris-Bannock fault on east and the Wasatch fault and its northward projection on the west). The Wasatch fault is the major east boundary fault of the Basin and Range structural province and is generally normal in character, usually having a steep westward dip. Bedrock includes strata from the younger Precambrian, all Paleozoic systems, and Tertiary and Quaternary deposits. Tertiary and Quaternary volcanic rocks and similar age gravels locally cover the older rocks and structures.

REFERENCE/CITATION: USFS, 1978, RARE II DES, ID, UT, and WY Suppls.; D0E, 1978, Energy Res. Assessments of RARE II Lands; DOE, 1978, Energy Res. Assessments, of Ten Alternatives-RARE II Lands; Powers, 1977, WGA Gdbk 29; Blackstone, 1978, Tectonic map of the Overthrust Belt: WGS: RMDGA, 1978, Estimates of Undiscovered Recoverable Hydrocarbon Resources (RARE-II); White and Williams, 1975, USGS Circ. 726; NOAA, 1977, Geothermal Energy Resources of the Western U.S.; USGS, 1945, Min. Res. Mo. Valley Region, Pts. 1,2,3; ERDA, 1976, NURE-Prelim. Rpt.; Armstrong and Oriel, 1965, AAPG Bull., v. 43; British Sulfur Corp., Ltd., 1964, A World Survey of Phosphate Deposits: Woodalls Ltd. (Printers), London; Gulbrandsen, 1966, Geochim. Cosmochim. Acta, v. 3, p. 769-778; Brobst and Pratt, 1973, USGS Prof. Paper 820; Worl and 0thers, 1974, USGS MR-60; Kinkel and Peterson, 1962, USGS MR-13; RMAG, 1972, Geologic Atlas of the Rocky Mountain Region: Denver, CO; Bond and Others, 1978, Geologic Map of Idaho: IBMG; Ross, C.P., 1941 , IBMG Pamph.. 57, pt. 111; Mansfield, 1927, USGS Prof. Paper 152; Leonard and Others, 1978, USGS OFR 78-360; USGS, 1964, Mineral and Water Resources of Idaho: 88th U.S. Congress; Vine, 1959, USGS Bul1. 1055-1. 
TRACT NO: 04178

NATIONAL FOREST: Caribou
ECOREG : 3112

WAR: 19

STATE/COUNTY: Idaho, Franklin
$100 \mathrm{~N} / \mathrm{G}: 99$ LATITUDE: $42^{\circ} 09^{\prime}$ LONGITUDE: $111^{\circ} 41^{\prime}$

\begin{tabular}{|c|c|c|c|c|}
\hline $\begin{array}{l}\text { INDIVIDUAL TRACT } \\
\text { RESOURCE RATINGS } \\
\end{array}$ & $\underline{\text { ORNL }}$ & USFS & $\underline{\mathrm{DOE}}$ & USGS \\
\hline OIL AND GAS & $4 / 1$ & 4 & 3 & \\
\hline URANIUM & $2 / 1$ & 1 & 1 & \\
\hline COAL & $1 / 2$ & 4 & 1 & \\
\hline GEOTHERMAL & $2 / 2$ & 1 & & \\
\hline CRITICAL MINERALS & $2 / 2$ & 1 & & \\
\hline $\begin{array}{l}\text { OVERALL RATING } \\
\text { (WEIGHTED) }\end{array}$ & 2 & & 3 & \\
\hline
\end{tabular}

REMARKS

Stratigraphic and structural traps compounded by thrusting; similar to Canadian Rockies Foothills Belt

NAMES OF CRITICAL MINERALS PRESENT: Base metals, chiefly $\mathrm{Cu}$ and Pb

COMMENTARY AND SUMMARY: Petroleum exploration has not been as intensive in the Paris-Bannock thrust belt as in the more easterly thrust structures; however, several holes showing some oil and gas have been completed in the past. The Rocky Mountain $0 i 1$ and Gas Association estimates that over 300 million barrels of oil and approximately three trillion cubic feet of gas occur in Rare II tracts in this belt. Phosphate resources are minor in comparison with the more easterly belts. Some potential for disseminated gold and base metals in the Precambrian and Lower Paleozoic strata is also present.

GEOLOGY: Paris-Bannock thrust belt (includes terrain between Paris-Bannock fault on east and the Wasatch fault and its northward projection on the west). The Wasatch fautt is the major east boundary fault of the Basin and Range structural province and is generally normal in character, usually having. a steep westward dip. Bedrock includes strata from the younger Precambrian, all Paleozoic systems, and Tertiary and Quaternary deposits. Tertiary and Quaternary volcanic rocks and similar age gravels locally cover the older rocks and structures.

REFERENCE/CITATION: USFS, 1978, RARE II DES, ID, UT, and WY Suppls.; DOE, 1978, Energy Res. Assessments of RARE II Lands; DOE, 1978, Energy Res. Assessments, of Ten Alternatives-RARE II Lands; Powers, 1977 , WGA Gdbk 29; Blackstone, 1978, Tectonic map of the Overthrust Belt: WGS; RMOGA, 1978, Estimates of Undiscovered Recoverable Hydrocarbon Resources (RARE-II); White and Williams, 1975, USGS Circ. 726; NOAA, 1977, Geothermal Energy Resources of the Western U.S.; USGS, 1945, Min. Res. Mo. Valley Region, Pts. 1,2,3; ERDA, 1976, NURE-Prelim. Rpt.; Armstrong and Oriel, 1965, AAPG Bull., v. 43; British Sulfur Corp., Ltd., 1964, A World Survey of Phosphate Deposits: Woodalls Ltd. (Printers), London; Gulbrandsen, 1966, Geochim. Cosmochim. Acta, v. 3, p. 769-778; Brobst and Pratt, 1973, USGS Prof. Paper 820; Worl and Others, 1974, USGS MR-60; Kinkel and Peterson, 1962, USGS MR-13; RMAG, 1972, Geologic Atlas of the Rocky Mounta in Region: Denver, CO; Bond and Others, 1978, Geologic Map of Idaho: IBMG; Ross, C.P., 1941, IBMG Pamph. 57, pt. 111; Mansfield, 1927, USGS Prof. Paper 152; Leonard and 0thers, 1978, USGS OFR 78-360; USGS, 1964, Mineral and Water Resources of Idaho: 88th U.S. Lungress; Vine, 1959, USGS Bull. 1055-1. 
ENERGY AND MINERAL RESOURCE EVALUATION - RARE II TRACTS

TRACT NO: 04179

NATIONAL FOREST: Caribou
TRACT NAME: Worm Creek
ECOREG : 3112

WAR: 21

ACREAGE (GROSS): 41,800 ACREAGE (NET): $41,565100 \mathrm{~N} / \mathrm{G}: 99$ LATITUDE: $42^{\circ} 07^{\prime} . . \quad$ LONGITUDE: $111^{\circ} 32^{\prime}$

\begin{tabular}{|c|c|c|c|c|}
\hline $\begin{array}{l}\text { INDIVIDUAL TRACT } \\
\text { RESOURCE RATINGS } \\
\end{array}$ & $\underline{\text { ORNL }}$ & $\underline{\text { USFS }}$ & $\underline{\mathrm{DOE}}$ & $\underline{\text { USGS }}$ \\
\hline OIL AND GAS & $4 / 1$ & 4 & 3 & \\
\hline URANIUPA & $2 / 1$ & 1 & 1 & \\
\hline COAL & $1 / 3$ & 1 & 1 & \\
\hline GEOTHERMAL & $2 / 2$ & 1 & & \\
\hline CRITICAL MINERALS & $2 / 3$ & 4 & & \\
\hline $\begin{array}{l}\text { OVERALL RATING } \\
\text { (WEIGHTED) }\end{array}$ & $2^{+}$ & & 3 & \\
\hline
\end{tabular}

STATE/COUNTY: Idaho, Bear Lake/Frankl in

REMARKS

Stratigraphic and structural traps compounded by thrusting; similar to Canadian Rockles Foothills Belt

NAMES OF CRITICAL MINERALS PRESENT: $\mathrm{CU}, \mathrm{Pb}$

COMMENTARY AND SUMMARY: Petroleum exploration has not been as intensive in the Paris-Bannock thrust belt as in the more easterly thrust structures; however, several holes showing some oil and gas have been completed in the past. The Rocky Mountain $01 \bar{l}$ and Gas Association estimates that over 300 milition barrels of oil and approximately three trillion cubic feet of gas occur in Rare II tracts in this belt. Phosphate resources are minor in comparison with the more easterly belts. Some potential for disseminated gold and base metals in the Precambrian and Lower Paleozoic strata is also present. DUE, monieratep r.nnflirt. rorridor R-4R.

GEOLOGY: Paris-Bannock thrust belt (includes terrain between Paris-Bannock fault on east and the Wasatch fault and its northward projection on the west). The Wasatch fault is the major east boundary fault of the Basin and Range structural province and is generally normal in character, usually having a steep westward dip. Bedrock includes strata from the younger Precambrian, all Paleozoic systems, and Tertiary and Quaternary deposits. Tertiary and Quaternary volcanic rocks and similar age gravels locally cover the older rocks and structures.

REFERENCE/CITATION: USFS, 1978, RARE II DES, ID, UT, and WY Suppls.; DOE, 1978, Energy Res. Assessments of RARE II Lands; DOE, 1978, Energy Res. Assessments, of Ten Alternatives-RARE II Lands; Powers, 1977, WGA GdbK 29; Blackstone, 1978, Tectonic map of the Overthrust Belt: WGS; RMOGA, 1978, Estimates of Undiscovered Recoverable Hydrocarbon Resources (RARE-II); White and Williams, 1975, USGS Circ. 726; NOAA, 1977, Geothermal Energy Resources of the Western U.S.; USGS, 1915, Min. Res. Mo. Valley Region, Pts. 1,2,3; ERDA, 1976, NURE-Prelim. Rpt.; Armstrong and Oriel, 1965, AAPG Bull., v. 43; British Sulfur Corp., Ltd., 1964, A World Survey of Phosphate Deposits: Woodalls Ltd. (Printers), London; Gulbrandsen, 1966, Geochim. Cosmochim. Acta, v. 3, p. 769-778; Brobst and Pratt, 1973, USGS Prof. Paper 820; Worl and 0thers, 1974, USGS MR-60; Kinkel and Peterson, 1962, USGS MR-13; RMAG, 1972, Geologic Atlas of the Rocky Mounta in Region: Denver, C0; Bond and Others, 1978, Geologic Map of Idaho: IBMG; Ross, C.P., 1941, IBMG Pamph. 57, pt. 111; Mansfield, 1927, USGS Prof. Paper 152; Leonard and 0thers, 1978, USGS OFR 78-360; USGS, 1964, Mineral and Water Resources of Idaho: 88th U.S. Congress; Vine, 1959, USGS Bu11. 1055-1. 
ENERGY AND MINERAL RESOURCE EVALUATION - RARE II TRACTS

TRACT NO: 04180

TRACT NAME: Swan Creek Mountain

ECOREG: 3112

WAR: 16

NATIONAL FOREST: Caribou/Wasatch

STATE/COUNTY: Idaho/Utah, Bear Lake/Rich/Cache/

Franklin

ACREAGE (GROSS): 20,800 ACREAGE (NET): $20,800100 \mathrm{~N} / \mathrm{G}: 100$ LATITUDE: $42^{\circ} 00^{\prime}$ LONGITUDE: $111^{\circ} 29^{\prime}$

\begin{tabular}{|c|c|c|c|c|}
\hline $\begin{array}{l}\text { INDIVIDUAL TRACT } \\
\text { RESOURCE RATINGS } \\
\end{array}$ & $\underline{\text { ORNL }}$ & $\underline{\text { USFS }}$ & $\underline{D O E}$ & $\underline{\text { USGS }}$ \\
\hline OIL AND GAS & $4 / 1$ & 4 & 3 & \\
\hline URANIUM & $2 / 1$ & 1 & 1 & \\
\hline COAL & $1 / 3$ & 1 & 1 & \\
\hline GEOTHERMAL & $2 / 2$ & 1 & & \\
\hline CRITICAL MINERALS & $2 / 3$ & 1 & & \\
\hline $\begin{array}{l}\text { OVERALL RATING } \\
\text { (WEIGHTED) }\end{array}$ & $2^{+}$ & & 3 & \\
\hline
\end{tabular}

NAMES OF CRITICAL MINERALS PRESENT: Metals, chiefly Pb and $\mathrm{Cu}$

COMMENTARY AND SUMMARY: Petroleum exploration has not been as intensive in the Paris-Bannock thrust belt as in the more easterly thrust structures; however, several holes showing some oil and gas have been completed in the past. The Rocky Mountain $0 i 1$ and Gas Association estimates that over 300 million barrels of oil and approximately three trillion cubic feet of gas occur in Rare II tracts in this belt. Phosphate resources are minor in comparison with the more easterly belts. Some potential for disseminated gold and base metals in the Precambrian and Lower Paleozoic strata is also present. DOE, moderate conflict corridor R-48.

GEOLOGY: Paris-Bannock thrust belt (includes terrain between Paris-Bannock fault on east and the Wasatch fault and its northward projection on the west). The Wasatch fault is the major east boundary fault of the Basin and Range structural province and is generally normal in character, usually having a steep westward dip. Bedrock includes strata from the younger Precambrian, all Paleozoic systems, and Tertiary and Quaternary deposits. Tertiary and Quaternary volcanic rocks and similar age gravels locally cover the older rocks and structures.

REFERENCE/CITATION: USFS, 1978, RARE II DES, ID, UT, and WY Suppls.; D0E, 1978, Energy Res. Assessments of RARE II Lands; DOE, 1978, Energy Res. Assessments, of Ten Alternatives-RARE II Lands; Powers, 1977, WGA Gdbk 29; Blackstone, 1978, Tectonic map of the Overthrust Belt: WGS; RMOGA, 1978, Estimates of Undiscovered Recoverable Hydrocarbon Resources (RARE-II); White and Williams, 1975, USGS Circ. 726; NOAA, 1977, Geothermal Energy Resources of the Western U.S.; USGS, 1945, Min. Res. Mo. Valley Region, Pts. 1,2,3; ERDA, 1976, NURE-Prelim. Rpt.; Armstrong and Oriel, 1965, AAPG Bull., v. 43; British Sulfur Corp., Ltd., 1964, A World Survey of Phosphate Deposits: Woodalls Ltd. (Printers), London; Gulbrandsen, 1966, Geochim. Cosmochim. Acta, v. 3, p. 769-778; Brobst and Pratt, 1973, USGS Prof. Paper 820; Worl and Others, 1974, USGS MR-60; Kinkel and Peterson, 1962, USGS MR-13; RMAG, 1972, Geologic Atlas of the Rocky Mountain Region: Denver, CO; Bond and Others, 1978, Geologic Map of Idaho: IBMG; RosS, C.P., 1941, IBMG Pamph. 57, pt. 111; Mansfield, 1927, USGS Prof. Paper 152; Leonard and 0thers, 1978, USGS OFR 78-360; USGS, 1964, Mineral and Water Resources of Idaho: 88th U.S. Congress; Vine, 1959, USGS Bul1. 1055-1. 
ENERGY AND MINERAL RESOURCE EVALUATION - RARE II TRACTS

TRACT NO: 04181

TRACT NAME: Gibson

ECOREG: 3112

WAR: 16

NATIONAL FOREST: Caribou/Wasatch

STATE/COUNTY: Idaho, Frankl in/Cache

ACREAGE (GROSS): 11,401 ACREAGE (NET): 11,401

$100 \mathrm{~N} / \mathrm{G}: 100$ LATITUDE: $42^{\circ} 00^{\prime}$

LONGITUDE: $117^{\circ} 34^{\prime}$

\begin{tabular}{|c|c|c|c|}
\hline $\begin{array}{l}\text { INDIVIDUAL TRACT } \\
\text { RESOURCE RATINGS }\end{array}$ & ORNL & USFS & $\underline{D O E}$ \\
\hline OIL $\Lambda N D$ G $\Lambda S$ & $4 / 1$ & 4 & 3 \\
\hline URANIUM & $2 / 1$ & 1 & 1 \\
\hline COAL & $1 / 3$ & 1 & 1 \\
\hline GEOTHERMAL & $2 / 2$ & 1 & \\
\hline CRITICAL MINERALS & $2 / 2$ & 1 & \\
\hline $\begin{array}{l}\text { OVERALL KAII ING } \\
\text { (WEIGHTED) }\end{array}$ & 2 & & 3 \\
\hline
\end{tabular}

NAMES OF CRITICAL MINERALS PRESENT: Base metaTs?

COMMENTARY AND SUMMARY: Petroleum exploration has not been as intensive in the Paris-Bannock thrust belt as in the more easterly thrust structures; however, several holes showing some oil and gas have been completed in the past. The Rocky Mountain 0 il and Gas Association estimates that over 300 million barrels of 0 il and approximately three trillion cubic feet of gas occur in Rare II tracts in this belt. Phosphate resources are minor in comparison with the more easterly belts. Some potential for disseminated gold and base metals in the Precambrian and Lower Paleozoic strata is also present.

GEOLOGY: Paris-Bannock thrust belt (includes terrain between Paris-Bannock fault on east and the Wasatch fault and its northward projection on the west). The Wasatch fault is the major east boundary fault of the Basin and Range structural province and is generally normal in character, usually having a steep westward dip. Bedrock includes strata from the younger Precambrian, all Paleozoic systems, and Tertiary and Quaternary deposits. Tertiary and Quaternary volcanic rocks and similar age gravels locally cover the older rocks and structures.

REFERENCE/CITATION: USFS, 1978, RARE II DES, ID, UT, and WY Suppls.; DOE, 1978, Energy Res. Assessments of RARE II Lands; DOE, 1978, Energy Res. Assessments, of Ten Alternatives-RARE II Lands; Powers, 1977 , WGA Gdbk 29; Blackstone, 1978, Tectonic map of the Overthrust Belt: WGS; RMOGA, 1978, Estimates of Undiscovered Recoverable Hydrocarbon Resources (RARE-II); White and Williams, 1975, USGS Circ. 726; NOAA, 1977, Geothermal Energy Resources of the Western U.S.; USGS, 1945, Min. Res. Mo. Valley Region, Pts. 1,2,3; ERDA, 1976, NURE-Prelim. Rpt.; Armstrong and Oriel, 1965, AAPG Bul1., v. 43; British Sulfur Corp., Ltd., 1964, A World Survey of Phosphate Deposits: Woodalls Ltd. (Printers), London; Gulbrandsen, 1966, Geochim. Cosmochim. Acta, v. 3, p. 769-778; Brobst and Pratt, 1973, USGS Prof. Paper 820; Worl and Others, 1974, USGS MR-60; Kinkel and Peterson, 1962, USGS MR-13; RMAG, 1972, Geologic Atlas of the Rocky Mountain Region: Denver, C0; Bond and Others, 1978, Geologic Map of Idaho: IBMG; Ross, C.P., 1941, IBMG Pamph. 57, pt. 111; Mansfield, 1927, USGS Prof. Paper 152; Leonard and 0thers, 1978, USGS OFR 78-360; USGS, 1964; Mineral and Water Resources of Idaho: 88th U.S. Congress; Vine, 1959, USGS Bul1. 1055-1. 
INDIVIDUAL TRACT RESOURCE RATINGS

OIL AND GAS : $\underline{\text { ORNL }}$

$2 / 1$

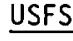

$\underline{D O E}$

USGS

$\begin{array}{lll}\text { OIL AND GAS } & 2 / 1 & 1 \\ \text { URANIUM } & 2 / 1 & 1 \\ \text { COAL } & 1 / 4 & 1 \\ \text { GEOTHERMAL } & 2 / 2 & 1 \\ \text { CRITICAL MINERALS } & 4 / 4 & 1\end{array}$

OVERALL RATING

(WEIGHTED)
1
NE

1

.

NAMES OF CRITICAL MINERALS PRESENT: P?; tale and asbestos

COMMENTARY AND SUMMARY: Part of the large La Barge hydrocarbon complex with the associated Greater Big Piney Gas Area is located in the central part of the Footwall Belt. Numerous smaller oil and/or gas fields also occur along nearly the entire length of the belt and include a recent major gas discovery in Teton County in a roaded salient extending deep into Rare II tract 4102 . Over 200 million barrels of 0 il and nearly 15 trillion cubic feet of gas have been estimated by the Rocky Mountain 0 il and Gas Association for Rare II tracts in this belt. The Permian Phosphoria Formation contains part of the region's large phosphate resources.

GEOLOGY: Footwall Belt of the Jackson-Prospect-Darby fault system (extends eastward to the crest of the Moxa Arch and its northward projection). Surface rocks are largely Tertiary in age, except in the north where the Gros Ventre, West Slope of the Tetons, and several smaller satellite Rare II tracts contain the entire regional stratigraphic sequence from Precambrian through lénzoic.

REFERENCE/CITATION: USFS, 1978, RARE II DES, ID, UT, and WY Suppl's.; DOE, 1978, Energy Res. Assessments of RARE II Lands; DOE, 1978, Energy Res. Assessments, of Ten Alternatives-RARE II Lands; Powers, 1977, WGA Gdbk 29; Blackstone, 1978, Tectonic Map of the Overthrust Be1t: WGS; RMOGA, 1978, Estimates of Undiscovered Recoverable Hydrocarbon Resources (RARE-II); White and Williams, 1975, USGS Circ. 726; NOAA, 1977, Geothermal Energy Resources of the Western U.S.; USGS, 1945, Min. Res. Mo. Valley Region, Pts 1, 2, 3; ERDA, 1976, NURE-Prelim. Rpt.; Armstrong and Oriel, 1965, AAPG Bull., v. 43; British Sulfur Corp., Ltd., 1964, A world survey of phosphate deposits: Woodalls Ltd. (Printers), London; Gulbrandsen, 1966, Geochim. Cosmochim. Acta, v. 3, 769-778; Brobst and Pratt, 1973, USGS Prof. Paper 820; Worl and Others, 1974, USGS MR-60; Kinkel and Peterson, 1962, USGS MR-13; RMAG, 1972, Geologic Atlas of the Rocky Mountain Region: Denver, C0; Love and Others, 1955, Geologic Map of Wyoming: USGS; Glass and 0thers, 1975, Energy Resources Map of Wyoming: WGS; Sheldon, 1965, USGS Prof. Paper 1313-B; Clàbough and others, 1946, USGS Mo. Basin Studies No. 9; USGS, 1964, MR-42; Chidester and Worthington, 1962, USGS MR-31; Love, 1961, USGS Prof. Paper 424-C; Chidester and Shride, 1962, USGS MR-17. 
ENERGY AND MINERAL RESOURCE EVALUATION - RARE II TRACTS

TRACT NO: 04611

TRACT NAME: Garns Mountain

ECOREG: 3112

WAR: 22

NATIONAL FÖREST: Targhee

STATE/COUNTY: Idaho, Bonneville/Madison/Teton

ACREAGE (GROSS): 114,790 ACREAGE (NET): $114,790100 \mathrm{~N} / \mathrm{G}: 100$ LATITUDE: $43^{\circ} 38^{\prime}$ LONGITUDE: $111^{\circ} 20^{\prime}$

INDIVIDUAL TRACT RESOURCE RATINGS

$\underline{\text { ORNL }} \underline{\text { USFS }} \quad \underline{\text { DOE }}$

RFMARKS

\begin{tabular}{|c|c|c|c|c|}
\hline OIL AND GAS & $1 / 1$ & 1 & 1 & $\begin{array}{l}\text { Stratigraphic and str } \\
\text { poundcd by thrusting } \\
\text { Ruckles Fuothllls Bel }\end{array}$ \\
\hline URANIUM & $3 / 2$ & 1 & 1 & Associated with coal \\
\hline COAL & $4 / 4$ & 4 & 1 & Horseshoe D1strict \\
\hline GEOTHERMAL & $2 / 2$ & 1 & & \\
\hline CRITICAL MINERALS & $4 / 4$ & 4 & & \\
\hline $\begin{array}{l}\text { OVERALL RATING } \\
\text { (WEIGHTED) }\end{array}$ & $4^{+}$ & & 4 & \\
\hline
\end{tabular}

NAMES OF CRITICAL MINERALS PRESENT: $\mathrm{P}(\mathrm{U}, \mathrm{V}, \mathrm{F}, \mathrm{Zn}, \mathrm{Cd}, \mathrm{Cr})$

COMMENTARY AND SUMMARY: The westward part of the La Barge hydrocarbon complex extends benea th the Jackson-Prospect-Darby Fault in the central part of the belt, and several smaller relatively shallow fields occur in the southern part of the belt. The Rocky Mountain Oil and Gas Association estimates that over 800 million barrels of oil and nearly five trillion cubic feet of gas occur in the Rare II tracts or parts thereof in the Jackson-Prospect-Darby thrust belt. Significant phosphate resources along with by-product potential in uranium, vanadium, chromium and other critical minerals occur in this belt.

GEOLOGY: Jackson-Prospect-Darby thrust belt (includes terrain westward to the surface trace of the Absaroka Fault). Surface strata are dominantly Cretaceous through Devonian in age, although locally some Lower Paleozoic rocks are exposed along the Footwall Fault, and some areas are covered by younger Tertiary sediments.

REFERENCE/CITATION: USFS, 1978, RARE II DES, ID, UT, and WY Suppls.; DnE, 1978, Energy Res. Assessments of RARE II Lands; DOE, 1978, Energy Res. Assessments, of Ten Alternatives-RARE II Lands; Powers, 1977 , WGA Gdbk 29; Blackstone, 1978, Tectonic map of the Overthrust Belt: WGS; RMOGA, 1978, Estimates of Undiscovered Recoverable Hydrocarbon Resources (RARE-II); White and Williams, 1975, USGS Circ. 726; NOAA, 1977, Geothermal Energy Resources of the Western U.S.; USGS, 1945, Min. Res. Mo. Valley Region,

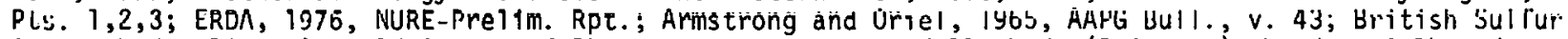
Corp., Ltd., 1964, A World Survey of Phosphate Deposits: Woodalls Ltd. (Printers), London; Gulbrandsen, 1966, Geochim. Cosmochim. Acta, v. 3, p. 769-778; Brobst and Pratt, 1973, USGS Prof. Paper 820; Worl and Others, 1974, USGS MR-60; Kinkel and Peterson, 1962, USGS MR-13; RMAG, 1972, Geologic Atlas of the Rocky Mounta in Region: Denver, C0; Bond and Others, 1978, Geologic Map of Idaho: IBMG; Ross, C.P., 1941, IBMG Pamph. 57, pt. 111; Mansfield, 1927, USGS Prof. Paper 152; Leonard and 0thers, 1978, USGS OFR 78-360; USGS, 1964, Mineral and Water Resources of Idaho: 88th U.S. Congress; Vine, 1959, IISGS.S Bu11. 1055-1. 
ENERGY AND MINERAL RESOURCE EVALUATION - RARE II TRACTS

TRACT NO: 04612

NATIONAL FOREST: Targhee
TRACT NAME: Moody Creek

ECOREG: 3112

WAR: 15

ACREAGE (GROSS): 9,350 ACREAGE (NET): 9,190 $100 \mathrm{~N} / \mathrm{G}: 98$ LATITUDE: $43^{\circ} 41^{\prime}$ LONGITUDE: $111^{\circ} 28^{\prime}$

INDIVIDUAL TRACT

RESOURCE RATINGS

OII. AND GAS

ORN

4/4

USFS

$\underline{\mathrm{DOE}}$

$\underline{\text { USGS }}$

4

URAN IUM

COAL

GEOTHERMAL

CRITICAL MINERALS

OVERALL RATING

(WEIGHTED)

$\begin{array}{ll}2 / 1 & 1 \\ 1 / 3 & 1 \\ 2 / 2 & 1 \\ 3 / 2 & 1 \\ 3 & \end{array}$

1

1

NAMES OF CRITICAL MINERALS PRESENT: $P(\dot{U}, \mathrm{~V}, \mathrm{~F}, \mathrm{Zn}, \mathrm{Cd}, \mathrm{Cr}$ )

COMMENTARY AND SUMMARY: The westward part of the La Barge hydrocarbon complex extends beneath the Jackson-Prospect-Darby Fault in the central part of the belt, and several smaller relatively shallow fields occur in the southern part of the belt. The Rocky Mountain $0 i 1$ and Gas Association estimates that over 800 million barrels of oil and nearly five trillion cubic feet of gas occur in the Rare II tracts or parts thereof in the Jackson-Prospect-Darby thrust belt. Significant phosphate resources along with by-product potential in uranium, vanadium, chromium and other critical minerals occur in this belt.

GEOLOGY: Jackson-Prospect-Darby thrust belt (includes terrain westward to the surface trace of the Absaroka Fault). Surface strata are dominantly Cretaceous through Devonian in age, although locally some Lower Paleozoic rocks are exposed along the Footwall Fault, and some areas are covered by younger Tertiary sediments.

REFERENCE/CITATION: USFS, 1978, RARE II DES, ID, UT, and WY Suppls.; DOE, 1978, Energy Res. Assessments of RARE II Lands; DOE, 1978, Energy Res. Assessments, of Ten Alternatives-RARE II Lands; Powers, 1977 , WGA Gdbk 29; Blackstone, 1978, Tectonic map of the Overthrust Belt: WGS; RMOGA, 1978, Estimates of Undiscovered Recoverable Hydrocarbon Resources (RARE-II); White and Williams, 1975, USGS Circ. 726; NOAA, 1977, Geothermal Energy Resources of the Western U.S.; USGS, 1945, Min. Res. Mo. Valley Region, Pts. 1,2,3; ERDA, 1976, NURE-Prelim. Rpt.; Armstrong and Oriel, 1965, AAPG Bull., v. 43; British Sulfur Corp., Ltd., 1964, A World Survey of Phosphate Deposits: Woodal1s Ltd. (Printers), London; Gulbrandsen, 1966, Geochim. Cosmochim. Acta, v. 3, p. 769-778; Brobst and Pratt, 1973, USGS Prof. Paper 820; Worl and Others, 1974, USGS MR-60; Kinke1 and Peterson, 1962, USGS MR-13; RMAG, 1972, Geologic Atlas of the Rocky Mountain Region: Denver, C0; Bond and Others, 1978, Geologic Map of Idaho: IBMG; Ross, C.P., 1941, IBMG Pamph. 57, pt. 111; Mansfield, 1927, USGS Prof. Paper 152; Leonard and 0thers, 1978, USGS OFR 78-360; USGS, 1964, Mineral and Water Resources of Idaho: 88th U.S. Congress; Vine, 1959, USGS Bul1. 1055-1. 
ENERGY AND MINERAL RESOURCE EVALUATION - RARE II TRACTS

TRACT. NO: 04613

TRACT NAME: Palisades

ECOREG : 3112

WAR: 21

NATIONAL FOREST: Targhee/Bridger-Teton

STATE/COUNTY: Idaho/Wyoming, Bonneville

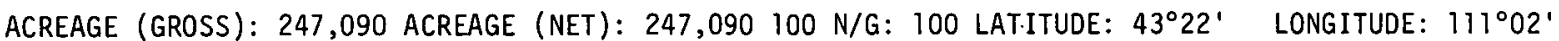

INDIVIDUAL TRACT
RESOURCE RATINGS

OIL AND GAS

ORNL

USFS

$\underline{D O E}$

$\underline{\text { USGS }}$

$4 / 3$

4

4

URANIÜM

$4 / 3$

4

3

$4 / 4$

.1

1

GEOTHERMAL

$3 / 2$

1

CRITICAL MINERALS

$4 / 4$

4

OVERALL RATING

(WEIGHTED)
REMARKS

Stratigraphic and structural traps compounded by thrusting; similar to Canadian Rockies Foothills Belt

Associated with coal

Honrseshọe District

NAMES OF CRITICAL MINERALS PRESENT: $P(U, V, F, Z n, C d, C r)$

COMMENTARY AND SUMMARY: The westward part of the La Barge hydrocarbon complex extends beneath the Jackson-Prospect-Darby Fault in the central part of the belt, and several smaller relatively shallow fields occur in the southern part of the belt. The Rocky Mountain $0 i 1$ and Gas Association estimates that over 800 million barrels of oil and nearly five trillion cubic feet of gas occur in the Rare II. tracts or parts thereof in the Jackson-Prospect-Darby thrust belt. Significant phosphate resources along with by-product potential in uranium, vanadium, chromium and other critical minerals occur in this belt.

GEOLOGY: Jackson-Prospect-Darby thrust belt (includes terrain westward to the surface trace of the Absaroka Fault). Surface strata are dominantly Cretaceous through Devonian in age, although locally some Lower Paleozoic rocks are exposed along the Footwall Fault, and some areas are covered by younger Tertiary sediments.

REFERENCE/CITATION: USFS, 1978, RARE II DES, ID, UT, and WY Suppls.; DoE, 1978, Energy Res. Assessments of RARE II Lands; DOE, 1978, Energy Res. Assessments, of Ten Alternatives-RARE II Lands; Powers, 1977 , WGA Gdbk 29; Blackstone, 1978, Tectonic map of the Overthrust Be1t: WGS; RMOGA, 1978, Estimates of Undiscovered Recoverable Hydrocarbon Resources (RARE-II); White and Williams, 1975, USGS Circ. 726; NOAA, 1977, Geothermal Energy Resources of the Western U.S.; USGS, 1945, Min. Res. Mo. Valley Region, Pts. 1,2,3; ERDA, 1976, NURE-Prelim. Rpt.; Armstrong and Oriel. 1965, AAPG Bul 1., v. 43;.British Sulfur Corp., Ltd., 1964, A World Survey of Phosphate Deposits: Woodalls Ltd. (Printers), London; Gulbrandsen, 1966, Géochim. Cosmochim. Acta, v. 3, p. 769-778; Brobst and Pratt, 1973, USGS Prof. Paper 820; Worl and Others, 1974, USGS MR-60; Kinkel and Peterson, 1962, USGS MR-13; RMAG, 1972, Geologic Atlas of the Rocky Mounta in Region: Denver, CO; Bond and Others, 1978, Geologic Map of. Idaho: IBMG; Ross, C.P., 1941, IBMG Pamph. 57, pt. 111; Mansfield, 1927, USGS Prof. Paper 152; Leonard and 0thers, 1978, USGS OFR 78-360; USGS, 1964; Mineral and Water Resources of Idaho: 88th U.S. Congress; Vine, 1959, USGS Bul1. 1055=1. 
ENERGY AND MINERAL RESOURCE EVALUATION - RARE II TRACTS

TRACT NO: 04614

NATIONAL FOREST: Targhee

INDIVIDUAL TRACT

RESOURCE RATINGS

OIL AND GAS

$\underline{\text { ORNL }}$

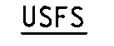

DOE

USGS

$4 / 4$

4

4

URAN IUM

COAL

GEOTHERMAL

CRITICAL MINERALS

$3 / 2$

$3 / 2$

$2 / 2$

$4 / 4$

OVERALL RATING

(WEIGHTED)
TRACT NAME: Bald Mountain

ECOREG: 3112

WAR: 15

STATE/COUNTY: Idaho, Bonneville

$100 \mathrm{~N} / \mathrm{G}: 100$ LATITUDE: $43^{\circ} 25^{\prime} \quad$ LONGITUDE : $111^{\circ} 26^{\prime}$

NAMES OF CRITICAL MINERALS PRESENT: $\mathrm{P}(\mathrm{U}, \mathrm{V}, \mathrm{F}, \mathrm{Zn}, \mathrm{Cd}, \mathrm{Cr})$

COMMENTARY AND SUMMARY: Several major and several lesser oil and/or gas fields are located in the southern part of the Absaroka Belt in Wyoming and Utah. Most production is from Jurassic-Triassic reservoirs, but more recent deeper discoveries are in Upper Paleozoic rocks (Phosphoria) and even more -recently in Lower Paleozoic rocks. The Rocky Mountain Oil and Gas Association estimates that Rare II tracts in the Absaroka belt contain nearly 3.3 billion barrels of oil and over 12.5 trillion cubic feet of gas. The major part of the Southeast Idaho phosphate resource is in this thrust belt, with much of $i t$ in the Rare II tracts. Not only are the phosphate rock resources important for the phosphorus, but there is a significant near-future potential for vanadium, uranium by-product production. The Mt. Pisgah gold district in Bonneville County may have significant potential for Carlin-type gold deposits (Rare II tracts $4160 ; 4161$, and 4162 ).

GEOLOGY: Absaroka thrust belt (includes terrain westward to surface trace of the Paris-Bannock thrust complex). Includes (as secondary structures) the Crawford, Meade, Medicine Lodge, Sheep Mountain, Skyline, and many smaller thrust faults. Rocks exposed at the surface include sedimentary rocks from Cambrian to Tertiary in age along with some Tertiary and Quaternary volcanics. Several small igneous intrusions of Tertiary Age have been mapped in the Idaho part of the Absaroka Belt, chiefly in the vicinity of the Mt. Pisgah gold district.

REFERENCE/CITATION: USFS, 1978, RARE II DES, ID, UT, and WY Suppls.; DOE, 1978, Energy Res. Assessments of RARE II Lands; DOE, 1978, Energy Res. Assessments, of Ten Alternatives-RARE II Lands; Powers, 1977 , WGA Gdbk 29; Blackstone, 1978, Tectonic map of the Overthrust Belt: WGS; RMOGA, 1978, Estimates of Undiscovered Recoverable Hydrocarbon Resources (RARE-II); White and Williams, 1975, USGS Circ. 726; NOAA, 1977, Geothermal Energy Resources of the Western U.S.; USGS, 1945, Min. Res. Mo. Valley Region, Pts. 1,2,3; ERDA, 1976, NURE-Prelim. Rpt.; Armstrong and Oriel, 1965, AAPG Bul1., v. 43; British Sulfur Corp., Ltd., 1964, A World Survey of Phosphate Deposits: Woodalls Ltd. (Printers), London; Gulbrandsen, 1966, Geochim. Cosmochim. Acta, v. 3, p. 769-778; Brobst and Pratt, 1973, USGS Prof. Paper 820; Worl and 0thers, 1974, USGS MR-60; Kinkel and Peterson, 1962, USGS MR-13; RMAG, 1972, Geologic Atlas of the Rocky Mounta in Region: Denver, C0; Bond and Others, 1978, Geologic Map of Idaho: IBMG; Ross, C.P., 1941, IBMG Pamph. 57, pt. 111; Mansfield, 1927, USGS Prof. Paper 152; Leonard and 0thers, 1978, USGS OFR 78-360; USGS, 1964, Mineral and Water Resources of Idaho: 88th U.S. Congress; Vine, 1959, USGS Bul1. 1055-1. 
ENERGY AND MINERAL RESOURCE EVALUATION - RARE II TRACTS

TRACT NO: 04615

TRACT NAME: Bear Creek

ECOREG: 3112

WAR: 18

NATIONAL FOREST: Targhee

STATE/COUNTY: Idaho, Bonneville

ACREAGE (GROSS): 78,700 ACREAGE (NET): 78,540 $100 \mathrm{~N} / \mathrm{G}: 100$ LATITUDE: $43^{\circ} 16^{\prime}$ LONGITUDE: $111^{\circ} 18^{\prime}$

INDIVIDUAL TRACT

RESOURCE RATINGS

OIL AND GAS

$\underline{\text { ORNL }} \underline{\text { USFS }} \underline{\text { DOE }} . \quad \underline{\text { USGS }}$

$4 / 4 \quad 4 \quad 4$

$\begin{array}{llll}\text { URANIUM } & 3 / 2 & 1 & 1 \\ \text { COAL } & 3 / 3 & 1 & 1 \\ \text { GEÜTHERMAL } & 3 / 2 & 1 & \\ \begin{array}{l}\text { CRITICAL MINERALS } \\ \begin{array}{l}\text { OVERALL RATING } \\ \text { (WEIGHTED) }\end{array}\end{array} & 4 / 4 & 4 & \\ \end{array}$

REMARKS

Stratigraphic and structural traps compounded by thrusting; similar to Canadian Rockies Foothills Belt

Assuciated with coal

Teturl basin field

Mt. Pisgah Au District

NAMES OF CRITICAL MINERALS PRESENT: $P(\mathrm{U}, \mathrm{V}, \mathrm{F}, \mathrm{Zn}, \mathrm{Cd}, \mathrm{Cr}) ; \mathrm{Au}(\mathrm{Ag})$

COMMENTARY AND SUMMARY: Several major and several lesser oil and/or gas fields are located in the southern part of the Absaroka Belt in Wyoming and Utah. Most production is from Jurassic-Triassic reservoirs, but more recent deeper discoveries are in Upper Paleozoic rocks (Phosphoria) and even more recently in Lower Paleozoic rocks. The Rocky Mountain $0 i l$ and Gas Association estimates that Rare II tracts in the Absaroka belt contain nearly 3.3 billion barrels of oil and over 12.5 trillion cubic feet of gas. The major part of the Southeast Idaho phosphate resource is in this thrust belt, with much of it in the Rare II tracts. Not only are the phosphate rock resources important for the phosphorus, but there is a significant near-future potential for vanadium, uranium by-product production. The Mt. Pisgah gold district in Bonneville County may have significant potential for Carlin-type gold deposits (Rare II tracts 04160, 04161, and 04162).

GEOLOGY: Absaroka thrust belt (includes terrain westward to surface trace of the Paris-Bannock thrust complex). Includes (as secondary structures) the Crawford, Meade. Medicine Lodge. Sheep Mountain, Skyline, and many smaller thrust faults. Rocks exposed at the surface include sedimentary rocks from Cambrian to Tertiary in age along with some Tertiary and Quaternary volcanics. Several small igneous intrusions of Tertiary Age have been mapped in the Idaho part of the Absaroka Belt, chiefly in the vicinity of the Mt. Pisgah gold district.

REFERENCE/CITATION: USFS, 1978, RARE II DES, ID, UT, and WY Suppls.; DOE, 1978, Energy Res. Assessments of RARE II Lands; DOE, 1978, Energy Res. Assessments, of Ten Alternatives-RARE II Lands; Powers, 1977, WGA Gdbk 29; Blackstone, 1978, Tectonic map of the Overthrust Belt: WGS; RMOGA, 1978, Estimates of Undiscovered Recoverable Hydrocarbon Resources (RARE-II); White and Williams, 1975, USGS Circ. 726; NOAA, 1977, Geothermal Energy Resources of the Western U.S.; USGS, 1945, Min. Res. Mo. Valley Region, Pts. 1,2,3; ERDA, 1976, NURE-Prelim. Rpt.; Armstrong and Oriel, 1965, AAPG Bul1., v. 43; British Sulfur Corp., Ltd., 1964, A World Survey of Phosphate Deposits: Woodalls Ltd. (Printers), London; Gulbrandsen, 1966, Geochim. Cosmochim. Acta, v. 3, p. 769-778; Brobst and Pratt, 1973, USGS Prof. Paper 820; Worl and Others, 1974, USGS MR-60; Kinkel and Peterson, 1962, USGS MR-13; RMAG, 1972, Geologic Atlas of the Rocky Mountain Region: Denver, CO; Bond and Others, 1978, Geologic Map of Idaho: IBMG; Ross, C.P., 1941, IBMG Pamph. 57, pt. 111; Mansfield, 1927, USGS Prof.' Paper 152; Leonard and Others, 1978, USGS OFR 78-360; USGS, 1964, Mineral and Water Resources of Idaho: 88th U.S. Congress; Vine, 1959, USGS Bul1. 1055-1. 
ENERGY AND MINERAL RESOURCE EVALUATION - RARE II TRACTS

TRACT NO: 04616

TRACT NAME: Poker Peak

ECOREG: 3112

WAR: 15

NATIONAL FOREST: Targhee

STATE/COUNTY: Idaho, Bonneville

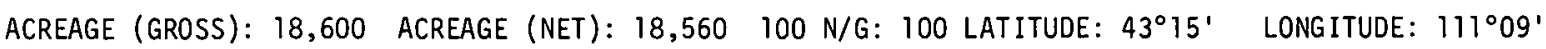

INDIVIDUAL TRACT

RESOURCE RATINGS

$\underline{\text { ORNL }} \quad \underline{\text { USFS }} \quad \underline{\mathrm{DOE}} \quad \underline{\mathrm{USGS}}$

REMARKS

OIL AND GAS

$4 / 3$

4

4

URANIUM

$3 / 1$

1

1

COAL

GEOTHERMAL

$1 / 4$

1

1

CRITICAL MINERALS

$3 / 2$

1

OVERALL RATING

(WEIGHTED)

$4 / 1$

1

Stratigraphic and structural traps compounded by thrusting; similar to Canadian Rockies Foothills Belt

NAMES OF CRITICAL MINERALS PRESENT: AU

COMMENTARY AND SUMMARY: Several major and several lesser oil and/or gas fields are located in the southern part of the Absaroka Belt in Wyoming and Utah. Most production is from Jurassic-Triassic reservoirs, but more recent deeper discoveries are in Upper Paleozoic rocks (Phosphoria) and even more recently in Lower Paleozoic rocks. The Rocky Mountain Oil and Gas Association estimates that Rare II tracts in the Absaroka belt contain nearly 3.3 billion barrels of oil and over 12.5 trillion cubic feet of gas. The major part of the Southeast Idaho phosphate resource is in this thrust belt, with much of it in the Rare II tracts. Not only are the phosphate rock resources important for the phosphorus, but there is a significant near-future potential for vanadium, uranium by-product production. The Mt. Pisgah gold district in Bonneville County may have significant potential for Carlin-type gold deposits (Rare II tracts 04160, 04161, and 04162).

GEOLOGY: Absaroka thrust belt (includes terrain westward to surface trace of the Paris-Bannock thrust complex). Includes (as secondary structures) the Crawford, Meade, Medicine Lodge, Sheep Mountain, Skyline, and many smaller thrust faults. Rocks exposed at the surface include sedimentary rocks from Cambrian to Tertiary in age along with some Tertiary and Quaternary volcanics. Several small igneous intrusions of Tertiary Age have been mapped in the Idaho part of the Absaroka Belt, chiefly in the vicinity of the Mt. Pisgah gold district.

REFERENCE/CITATION: USFS, 1978, RARE II DES, ID, UT, and WY Suppls.; DOE, 1978, Energy Res. Assessments of RARE II Lands; DOE, 1978, Energy Res. Assessments, of Ten Alternatives-RARE II Lands; Powers, 1977, WGA Gdbk 29; Blackstone, 1978, Tectonic map of the Overthrust Belt: WGS; RMOGA, 1978, Estimates of Undiscovered Recoverable Hydrocarbon Resources (RARE-II); White and Williams, 1975, USGS Circ. 726; NOAA, 1977, Geothermal Energy Resources of the Western U.S.; USGS, 1945, Min. Res. Mo. Valley Region, Pts. 1,2,3; ERDA, 1976, NURE-Prelim. Rpt.; Armstrong and Oriel, 1965, AAPG Bul1., v. 43; British Sulfur Corp., Ltd., 1964, A World Survey of Phosphate Deposits: Woodalls Ltd. (Printers), London; Gulbrandsen, 1966, Geochim. Cosmochim. Acta, v. 3, p. 769-778; Brobst and Pratt, 1973, USGS Prof. Paper 820; Worl and 0thers, 1974, USGS MR-60; Kinkel and Peterson, 1962, USGS MR-13; RMAG, 1972, Geologic Atlas of the Rocky Mountain Region: Denver, CO; Bond and Others, 1978, Geologic Map of Idaho: IBMG; Ross, C.P., 1941, IBMG Pamph. 57, pt. 111; Mansfield, 1927, USGS Prof. Paper 152; Leonard and 0thers, 1978, USGS OFR 78-360; USGS, 1964, Mineral and Water Resources of Idaho: 88th U.S. Congress; Vine, 1959, USGS Bul1. 1055-1. 
INDIVIDUAL TRACT RESOURCE RATINGS

UIL ANIJ LiAS

$$
\text { ORNL }
$$

$\underline{\text { USFS }}$

$\underline{D O E} \quad \underline{U S G S}$

$$
4 / \%
$$

$\therefore 1$

2

URANIUM

COAL

GEOTHERMAL

CRITICAL MINERALS

$$
2 / 1
$$

OVERALL RATING (WEIGHTED)

4$$
1
$$$$
1
$$

2
REMARKS

Stratigraphic and structural traps com-
pounded by thrusting; similar to Canadian Rockies Foothills Belt

NAMES OF CRITICAL MINERALS PRESENT: Base and precious metals?

COMMENTARY AND SUMMARY: Petroleum exploration has not been as intensive in the Paris-Bannock thrust belt as in the more easterly thrust structures; however, several holes showing some oil and gas have been completed in the past. The Rocky Mountain 0il and Gas Association estimates that over 300 million barrels of oil and approximately three trillion cubic feet of qas occur in Rare II tracts in this belt. Phosphate resources are minor in comparison with the more easterly belts. Some potential for disseminated gold and base metals in the Precambrian and Lower Paleozoic strata is also present. May be traverged by existing gas pipelinie.

GEOLOGY: Paris-Bannock thrust belt (includes terrain between Paris-Bannock fault on east and the Wasatch fault and its northward projection on the west). The Wasatch fault is the major east boundary fault of the Basin and Range strúctural province and is generally normal in character, usually having a steep westward dip. Bedrock includes strata from the younger Precambrian, all Paleozoic systems, and Tertiary and Quaternary deposits. Tertiary and Quaternary volcanic rocks and similar age gravels locally cover the older rocks and structures.

REFERENCE/CITATION: USFS, 1978, RARE II DES, ID, UT, and WY Suppls.; D0E, 1978, Energy Res. Assessments of RARE II Lands; DOE, 1978, Energy Res. Assessments, of Ten Alternatives-RARE II Lands; Powers, 1977 , WGA Gdbk 29; Blackstone, 1978, Tectonic Map of the Overthrust. Belt:: WG.S; RMnGA, 1978, Est.imates nf Undiscovered Recoverable Hydrocarbon Kesources (RARE-II); White and Williams, 1975, USGS Circ. 726; NOAA, 1977, Geothermal Energy Resources of the Western U.S.; USGS, 1945, Min. Res. Mo. Valley Region, Pts. 1, 2, 3; ERDA, 1976, NURE-Prelim. Rpt.; Armstrong and Oriel, 1965, AAPG Bull., v. 43; British Sulfur Corp., Ltd., 1964, A World Survey of Phosphate Deposits: Woodalls Ltd. (Printers), London; Gulbrandsen, 1966, Geochim. Cosmochim. Acta, v. 3, p. 769-778; Brobst and Pratt, 1973, USGS Prof. Paper 820; Wor 1 and Others, 1974, USGS MR-60; Kinkel and Peterson, 1962, USGS MR-13; RMAG, 1972, Geologic Atlas of the Rocky Mountain Region: Denver, CO; Stokes and Madsen, 1961, Geologic Map of Utah-Northeast Quarter: UGMS; USGS, 1964, Mineral and Water Resources of Utah: 88th U.S. Congress; White, 1962, USGS MR-20. 
ENERGY AND MINERAL RESOURCE EVALUATION - RARE II TRACTS

TRACT N0: 04756

NATIONAL FOREST: Wasatch
TRACT NAME: Francis

ECOREG : 3112

WAR: 21

STATE/COUNTY: Utah, Davis/Morgan

\begin{tabular}{|c|c|c|c|c|c|}
\hline $\begin{array}{l}\text { INDIVIDUAL TRACT } \\
\text { RESOURCE RATINGS } \\
\end{array}$ & ORNL & USFS & DOE & USGS & REMARKS \\
\hline OIL AND GAS & $4 / 2$ & 1 & 2 & & $\begin{array}{l}\text { Stratigraphic and structural traps com- } \\
\text { pounded by thrusting; similar to Canadian } \\
\text { Rockies Foothills Belt }\end{array}$ \\
\hline URANIUM & $2 / 1$ & 1 & 1 & - & \\
\hline COAL & $1 / 4$ & 1 & 1 & & \\
\hline GEOTHERMAL & $2 / 2$ & 1 & & & \\
\hline CRITICAL MINERALS & $2 / 2$ & 1 & & & - \\
\hline $\begin{array}{l}\text { OVERALL RATING } \\
\text { (WEIGHTED) }\end{array}$ & $1^{+}$ & & 2 & & \\
\hline
\end{tabular}

NAMES OF CRITICAL MINERALS PRESENT: Base metals?

COMMENTARY AND SUMMARY: Petroleum exploration has not been as intensive in the Paris-Bannock thrust belt as in the more easterly thrust structures; however, several holes showing some oil and gas have been completed in the past. The Rocky Mountain 0 il and Gas Association estimates that over 300 million barrels of oil and approximately three trillion cubic feet of gas occur in Rare II tracts in this belt. Phosphate resources are minor in comparison with the more easterly belts. Some potential for disseminated gold and base metals in the Precambrian and Lower Paleozoic strata is also present. May be traversed by existing gas pipeline.

GEOLOGY: Paris-Bannock thrust belt (includes terrain between Paris-Bannock fault on east and the Wasatch fault and its northward projection on the west). The Wasatch fault is the major east boundary fault of the Basin and Range structural province and is generally normal in character, usually having a steep westward dip. Bedrock includes strata from the younger Precambrian, all Paleozoic systems, and Tertiary and Quaternary deposits. Tertiary and Quaternary volcanic rocks and similar age gravels locally cover the older rocks and structures.

REFERENCE/CITATION: USFS, 1978, RARE II DES, ID, UT, and WY Suppls.; DOE, 1978, Energy Res. Assessments of RARE II Lands; DOE, 1978, Energy Res. Assessments, of Ten Alternatives-RARE II Lands; Powers, 1977, WGA Gdbk 29; Blackstone, 1978, Tectonic Map of the Overthrust Belt: WGS; RMOGA, 1978, Estimates of Undiscovered Recoverable Hydrocarbon Resources (RARE-II); White and Williams, 1975, USGS Circ. 726; NOAA, 1977, Geothermal Energy Resources of the Western U.S.; USGS, 1945, Min. Res. Mo. Valley Region, Pts. 1, 2, 3; ERDA, 1976, NURE-Prelim. Rpt.; Armstrong and Oriel, 1965, AAPG Bul1., v. 43; British Sulfur Corp., Ltd., 1964, A World Survey of Phosphate Deposits: Woodal is Ltd. '(Printers), London; Gulbrandsen, 1966, Geochim. Cosmochim. Acta, v. 3, p. 769-778; Brobst and Pratt, 1973, USGS Prof. Paper 820; Worl and Others, 1974; USGS MR-60; Kinkel and Peterson, 1962, USGS MR-13; RMAG, 1972, Geologic Atlas of the Rocky Mountain Region: Denver, C0; Stokes and Madsen, 1961, Geologic Map of. Utah-Northeast Quarter: UGMS; USGS, 1964, Mineral and Water Resources of Utah: 88th U.S. Congress; White, 1962, USGS MR-20. 


\begin{tabular}{|c|c|c|c|}
\hline $\begin{array}{l}\text { INDIVIDUAL TRACT } \\
\text { RESOURCE RATINGS } \\
\end{array}$ & $\underline{\text { ORNL }}$ & $\underline{\text { USFS }}$ & $\underline{D O E}$ \\
\hline OIL AND GAS & $4 / 2$ & 1 & 3 \\
\hline URANIUM & $2 / 2$ & 1 & 1 \\
\hline COAL & $3 / 1$ & 4 & 1 \\
\hline GEOTHERMAL & $2 / 2$ & 1 & \\
\hline CRITIC.AI. MTNFRAIS & $2 / 2$ & 4 & \\
\hline $\begin{array}{l}\text { OVERALL RATING } \\
\text { (WEIGHTED) }\end{array}$ & 2 & & 3 \\
\hline
\end{tabular}

NAMES OF CRITICAL MINERALS PRESENT: Base metals?

COMMENTARY AND SUMMARY: Petroleum exploration has not been as intensive in the Paris-Bannock thrust belt as in the more easterly thrust structures; however, several holes showing some oil and gas have been completed in the past. The Rocky Mountain $0 i l$ and Gas Association estimates that over $300 \mathrm{million}$ barrels of oil and approximately three trillion cubic feet of gas occur in Rare II tracts in this belt. Phosphate resources are minor in comparison with the more easterly belts. Some potential for disseminated gold and base metals in the Precambrian and Lower Paleozoic strata is also present.

GEOLOGY: Paris-Bannock thrust belt (includes terrain between Paris-Bannock fault on east and the Wasatch fault and its northward projection on the west). The Wasatch fault is the major east boundary fault of the Basin and Range structural province and is generally normal in character, usually having a steep westward dip. Bedrock includes strata from the younger Precambrian, all Paleozoic systems, and Tertiary and Quaternary deposits. Tertiary and Quaternary volranic rocks and similar age gravels locally cover the older rocks and struçtures.

REFERENCE/CITATION: USFS, 1978, RARE II DES, ID, UT, and WY Suppls.; DOE, 1978, Energy Res. Assessments of RARE II Lands; DOE, 1978, Energy Res. Assessments, of Ten Alternatives-RARE II Lands; Powers, 1977 , WGA Gdbk 29; Blackstone, 1978, Tectonic Map of the Overthrust Belt: WGS; RMOGA, 1978, Estimates of Undiscovered Recoverable Hydrocarbon Resources (RARE-II); White and Williams, 1975, USGS Circ. 726; NOAA, 1977, Geothermal Enerqy Resources of the Western U.S.; USGS, 1945, Min. Rec. Mn. Valley Rejion, Pts. 1, 2, 3; ERDA, 1976, NÜRE-Prelim. Rpt.; Armstrong and Oriel, 1965, AAPG BUll., v. 43; British Sulfur Corp., Ltd., 1964, A World Survey of Phosphate Deposits: Woodal is Ltd. (Printers), London; Gulbrandsen, 1966, Geochim. Cosmochim. Acta, v. 3, p. 769-778; Brobst and Pratt, 1973, USGS Prof. Paper 820; Worl and Others, 1974, USGS MR-60; Kinkel and Peterson, 1962, USGS MR-13; RMAG, 1972, Geologic Atlas of the Rocky Mountain Region: Denver, C0; Stokes and Madsen, 1961, Geologic Map of Utah-Northeast Quarter: UGMS; USGS, 1964, Mineral and Water Resources of Utah: 88th U.S. Congress; White, 1962, USGS MR-20. 
ENERGY AND MINERAL RESOURCE EVALUATION - RARE II TRACTS ।

TRACT NO: 04759

NATIONAL FOREST: Wasatch

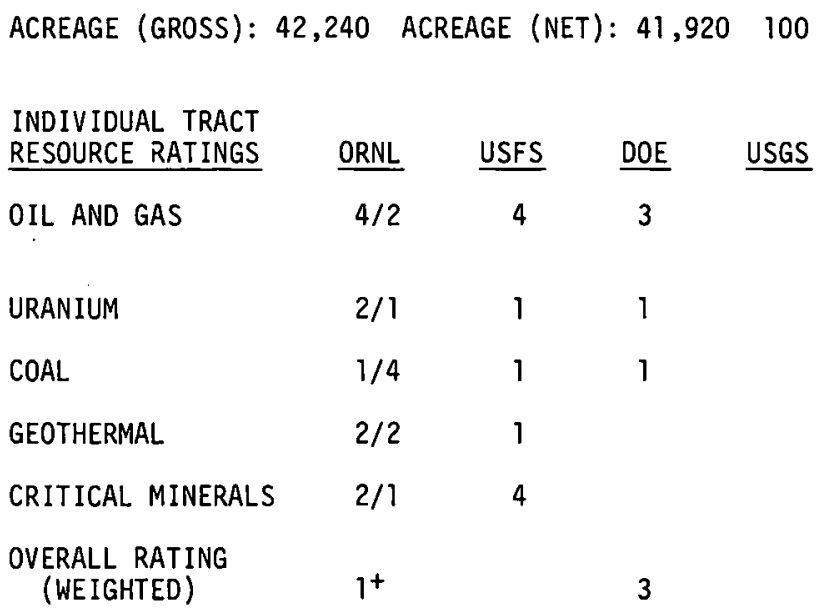

TRACT NAME: Mount Logan

STATE/COUNTY: Utah, Cache

ECOREG: $3112 \quad$ WAR: 16
N/G: 99 LATITUDE: $41^{\circ} 43^{\prime}$ LONGITUDE: $11^{\circ} 43^{\prime}$

NAMES OF CRITICAL MINERALS PRESENT: Base and precious metals?

COMMENTARY AND SUMMARY: Petroleum exploration has not been as intensive in the Paris-Bannock thrust belt as in the more easterly thrust structures; however, several holes showing some oil and gas have been completed in the past. The Rocky Mountain 0il and Gas Association estimates that over 300 million barrels of oil and approximately three trillion cubic feet of gas occur in Rare II tracts in this belt. Phosphate resources are minor in comparison with the more easterly belts. Some potential for disseminated gold and base metals in the Precambrian and Lower Paleozoic strata is also present.

GEOLOGY: Paris-Bannock thrust belt (includes terrain between Paris-Bannock fault on east and the Wasatch fault and its northward projection on the west). The Wasatch fault is the major east boundary fault of the Basin and Range structural province and is generaily normal in character, usually having a steep westward dip. Bedrock includes strata from the younger Precambrian, all Paleozoic systems, and Tertiary and Quaternary deposits. Tertiary and Quaternary volcanic rocks and similar age gravels locally cover the older rocks and structures.

REFERENCE/CITATION: USFS, 1978, RARE II DES; ID, UT, and WY Suppls.; DOE, 1978, Energy Res. Assessments of RARE II Lands; DOE, 1978, Energy Res. Assessments, of Ten Alternatives-RARE II Lands; Powers, 1977 , WGA Gdbk 29; Blackstone, 1978, Tectonic. Map of the Overthrust Belt: WGS; RMOGA, 1978, Estimates of Undiscovered Recoverable Hydrocarbon Resources (RARE-II); White and Williams, 1975, USGS Circ. 726; NOAA, 1977, Geothermal Energy Resources of the Western U.S.; USGS, 1945, Min. Res. Mo. Valley Region, Pts. 1, 2, 3; ERDA, 1976, NURE-Prelim. Rpt.; Armstrong and Oriel, 1965, AAPG Bull., v. 43; British Sulfur Corp., Ltd., 1964, A World Survey of Phosphate Deposits: Woodalls Ltd. (Printers), London; Gulbrandsen, 1966, Geochim. Cosmochim. Acta, v. 3, p. 769-778; Brobst and Pratt, 1973, USGS Prof. Paper 820; Worl and Others, 1974, USGS MR-60; Kinkel and Peterson, 1962, USGS MR-13; RMAG, 1972, Geologi.c Atlas of the Rocky Mountain Region: Denver, CO; Stokes and Madsen, 1961, Geologic Map of Utah-Northeast Quarter: UGMS; USGS, 1964, Mineral and Water Resources of Utah: 88th U.S. Congress; White, 1962, USGS MR-20. 
ENERGY AND MINERAL RESOURCE EVALUATION - RARE II TRACTS

TRACT N0: 04760

NATIONAL FOREST: Wasatch

ACREAGE (GROSS): 23,780

TRACT NAME: Wellsville Mountain

ECOREG: 3112

WAR: 23

STATE/COUNTY: Utah, Cache/Elder

INDIVIDUAL TRACT

P.ESOURGE RATINGS

OIL AND GAS

$\underline{\text { ORNL }}$

$4 / 1$

USFS

DOE

USGS

3

URANIUM

COAL

GEOTHERMAL

CRITICAL MINERALS

$2 / 1$

$1 / 4$

1

1

OVERALL RATING

(WEIGHTED)

$3^{+}$

$3 / 2 \quad 1$

$1 / 3 \quad 1$

NAMES OF CRITICAL MINERALS PRESENT: Base metals and Sb

COMMENTARY AND SUMMARY: Petroleum exploration has not been as intensive in the Paris-Bannock thrust belt as in the more easterly thrust structures; however, several holes showing some oil and gas have been completed in the past. The Rocky Mountain $0 i 1$ and Gas Association estimates that over 300 million barrels of oil and approximately three trillion cubic feet of gas occur in Rare II tracts in this belt. Phosphate resources are minor in comparison with the more easterly belts. Some potential for disseminated gols and base metals in the Precambrian and Lower Palenzoire strata is also present. May be traverced by oxicting gas pipclinc:

GEOLOGY: Paris-Bannock thrust belt (includes terrain between Paris-Bannock fault on east and the Wasatch fault and its northward projection on the west). The Wasatch fault is the major east boundary fault of the Basin and Range structural province and is generally normal in character, usually having a steep westward dip. Bedrock includes strata from the younger Precambrian, all Paleozoic systems, and Tertiary and Quaternary deposits. Tertiary and Quaternary volcanic rocks and similar age gravels locally cover the older rocks and structures.

REFERENCE/CITATION: USFS, 1978, RARE II DES, ID, UT, and WY Suppls.; DOE, 1978, Energy Res. Assessments of RARE II Lands; DOE, 1978, Energy Res. Assessments, of Ten Alternatives-RARE II Lands; Powers, 1977, WGA Gdbk 29; Blackstone, 1978, Tectonic Map of the Overthrust Belt: WGS; RMOGA, 1978, Fstimates of Undiscovered Recoverable Hydrocarbon Resources (KAKE-II); White and Williams, 1975, USGS Circ. 726; NOAA, 1977, Geothermal Energy Resources of the Western U.S.; USGS, 1945, Min. Res. Mo. Valley Region, Pts. 1, 2, 3; ERDA, 1976, NURE-Prelim. Rpt.; Armstrong and Oriel, 1965, AAPG Bull., v. 43; British Sulfur Corp., Ltd., 1964, A World Survey of Phosphate Deposits: Woodal ls Ltd. (Printers), London; Gulbrandsen, 1966, Geochim. Cosmochim. Acta, v. 3, p. 769-778; Brobst and Pratt, 1973, USGS Prof. Paper 820; Worl and Others, 1974, USGS MR-60; Kinkel and Peterson, 1962, USGS MR-13; RMAG, 1972, Geologic Atlas of the Rocky Mountain Region: Denver, C0; Stokes and Madsen, 1961, Geologic Map of Utah-Northeast Quarter: UGMS; USGS, 1964, Mineral and Water Resources of Utah: 88th U.S. Congress; White, 1962, USGS MR-20. 
ENERGY AND MINERAL RESOURCE EVALUATION - RARE II TRACTS

TRACT NO: 04761

TRACT NAME: Molliens Hollow

ECOREG : 3112

WAR: 19

NATIONAL FOREST: Wasatch

STATE/COUNTY: Utah, Cache

ACREAGE (GROSS): 16,900 ACREAGE (NET): $16,500100 \mathrm{~N} / \mathrm{G}: 98$ LATITUDE: $41^{\circ} 33^{\prime}$ LONGITUDE: $110^{\circ} 31^{\prime}$

INDIVIDUAL TRACT

RESOURCE RATINGS

OIL AND GAS

$\underline{\text { ORNL }}$

USFS $\underline{\text { DOE }} \quad \underline{\text { USGS }}$

$\begin{array}{lll}4 / 2 & 4 & 3\end{array}$

URANIUM

COAL

GEOTHERMAI

CRITICAL MINERALS

OVERALL RATING

(WEIGHTEU)
$2 / 1$

$1 / 4$

$2 / 2$

$2 / 1$

2-
1

1

1

NAMES OF CRITICAL MINERALS PRESENT: Base metals?

COMMENTARY AND SUMMARY: Petroleum exploration has not been as intensive in the Paris-Bannock thrust belt as in the more easterly thrust structures; however, several holes showing some oil and gas have been completed in the past. The Rocky Mountain 0 il and Gas Association estimates that over 300 million barrels of oil and approximately three trillion cubic feet of gas occur in Rare II tracts in this belt. Phosphate resources are minor in comparison with the more easterly belts. Some potential for disseminated gold and base metals in the Precambrian and Lower Paleozoic strata is also present.

GEOLOGY: Paris-Bannock thrust belt (includes terrain between Paris-Bannock fault on east and the Wasatch fault and its northward projection on the west). The Wasatch fault is the major east boundary fault of the Basin and Range structural province and is generally normal in character, usually having a steep westward dip. Bedrock includes strata from the younger Precambrian, all Paleozoic systems, and Tertiary and Quaternary deposits. Tertiary and Quaternary voleanic rocks and similar age gravels locally cover the older rocks and structures.

REFERENCE/CITATION: USFS, 1978, RARE II DES, ID, UT, and WY Suppls,; D0E, 1978, Energy Res. Assessments of RARE II Lands; DOE, 1978, Energy Res. Assessments, of Ten Alternatives-RARE II Lands; Powers, 1977, WGA Gdbk 29; Blackstone, 1978, Tectonic Map of the Overthrust Be1t: WGS; RMOGA, 1978, Estimates of Undiscovered Recoverable Hydrocarbon Resources (RARE-II); White and W1111ams, 1975., USGS Circ. 726; NOAA, 1977, Geothermal Energy Resources of the Western U.S.; USGS, 1945, Min. Res. Mo. Valley Region, Pts. 1, 2, 3; ERDA, 1976, NURE-Prelim: Rpt.; Armstrong and Oriel, 1965, AAPG Bull., v. 43; British Sulfur Corp., Ltd., 1964, A World Survey of Phosphate Deposits: Woodal is Ltd. (Printers), London; Gulbrandsen, 1966, Geochim. Cosmochim. Acta, v. 3, p. 769-778; Brobst and Pratt, 1973, USGS Prof. Paper 820; Worl and Others, 1974, USGS MR-60; Kinkel and Peterson, 1962, USGS MR-13; RMAG, 1972, Geologic Atlas of the Rocky Mountain Region: Denver, CO; Stokes and Madsen, 1961, Geologic Map of Utah-Northeast Quarter: UGMS; UȘGS, 1964, Mineral and Water Resources of Utah: 88th U.S. Congress; White, 1962, USGS MR-20. 
ENERGY AND MINERAL RESOURCE EVALUATION - RARE II TRACT'S

TRACT NO: 04762

TRACT NAME: Willard

ECOREG: 3112

WAR: 17

NATIONAL FOREST: Wasatch

STATE/COUNTY: Utah, Elder/Weber

ACREAGE (GROSS): 17,480 ACREAGE (NET): $16,580100 \mathrm{~N} / \mathrm{G}: 95$ LATITUDE: $41^{\circ} 24^{\prime}$ LONGITUDE: $111^{\circ} 59^{\prime}$

INDIVIDUAL TRACT

RESOURCE RATINGS

$\underline{\text { ORNL }}$

USFS

1

DOE USGS

OIL AND GAS

$4 / 1$

$2 / 1$

$\dot{4}$

2

URANIUM

$1 / 4$

I

1

GEOTHERMAL

CRITICAL MINERALS

$2 / 2$

1

$4 / 4$

4

2
OVERALL RATING

(WEIGHTED)

$3^{-}$

NAMES OF CRITICAL MINERALS PRESENT: Base metals
Stratigraphic and structural traps compounded by thrusting; similạ to Canadian Rorkips Fnnthills Relt

Potential in Tertiary rocks

COMMENTARY AND SUMMARY: Petroleum exploration has not been as intensive in the Paris-Bannock thrust belt as in the more easterly thrust structures; however, several holes showing some oil and gas have been completed in the past. The Rocky Mountain 0il and Gas Association estimates that over 300 million barrels of oil and approximately three trillion cubic feet of gas occur in Rare II tracts in this belt. Phosphate resources are minor in comparison with the more easterly belts. Some potential for disseminated gold and base metals in the Precambrian and Lower Paleozoic strata is also present.

GEOLOGY: Paris-Bannock thrust belt (includes terrain between Paris-Bannock fault on east and the Wasatch fault and its northward projection on the west). The Wasatch fault is the major east boundary fault of the Basin and Range structural province and is generally normal in character, usually having a steep westward dip. Bedrock includes strata from the younger Precambrian, all Paleozoic systems, and Tertiary and Quaternary deposits. Tertiary and Quaternary volcanic rocks and similar age gravels locally cover the older rocks and structures.

REFERENCE/CITATION: USFS, 1978, RARE II DES, ID, UT, and WY Suppls.; D0E, 1978, Energy Res. Assessments of RARE II Lands; D0E, 1978, Energy Res. Assessments, of Ten Alternatives-RARE II Lands; Powers, 1977, WGA Gdbk 29; Blackstone, 1978, Tectonic Map of the Overthrust Belt: WGS; RMOGA, 1978, Estimates of Undiscovered Recoverable Hydrocarbon Resources (RARE-II); White and Williams, 1975, USGS Circ. 726; NOAA, 1977, Geothermal Energy Resources of the Western U.S.; USGS, 1945, Min. Res. Mo. Valley Region. Pts. 1, 2, 3; ERDA, 1976, NURE-Prelim. Rpt.; Armstrong and Orie1, 1965, AAPG Bull., v. 43; British Sulfur Corp., Ltd., 1964, A World Survey of Phosphate Deposits: Woodalis Ltd. (Printers), London; Gulbrandsen, 1966, Geochim. Cosmochim. Acta, v. 3, p. 769-778; Brobst and Pratt, 1973, USGS Prof. Paper 820; Worl and Others, 1974, USGS MR-60; Kinkel and Peterson, 1962, USGS MR-13; RMAG, 1972, Geologic Atlas of the Rocky Mounta in Region: Denver, CO; Stokes and Madsen, 1961, Geologic Map of Utah-Northeast Quarter: UGMS; USGS, 1964, Mineral and Water Resources of Utah: 88th U.S. Congress; White, 1962, USGS $M R=20$. 
ENERGY AND MINERAL RESOURCE EVALUATION - RARE II TRACTS

TRACT NO: 04763

TRACT NAME: Lewis Peak

ECOREG: 3112

WAR: 19

NATIONAL FOREST: Wasatch

STATE/COUNTY: Utah, Weber

ACREAGE (GROSS): 11,500 ACREAGE (NET): $11,500100 \mathrm{~N} / \mathrm{G}: 100$ LATITUDE: $41^{\circ} 17^{\prime}$ LONGITUDE: $111^{\circ} 54^{\prime}$

INDIVIDUAL TRACT

RESOURCE RATINGS

OIL AND GAS

$\underline{\text { ORNL }} \quad \underline{\text { USFS }} \quad \underline{\mathrm{DOE}} \quad \underline{\text { USGS }}$

$4 / 1$

$2 / 1$

URANIUM

COAL

GEOTHERMAL

CRITICAL , MINERALS

OVERALL RATING

(WE IGHTED)

$1 / 4$

$3 / 2$

$4 / 1$

$2^{+}$
2

2

1

1

1

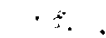

2
REMARKS Stratigraphic and structural traps compounded by thrusting; similar to Canadian Rockies Foothills Belt

NAMES OF CRITICAL MINERALS PRESENT: (Asbestos, taic)?

COMMENTARY AND SUMMARY: Petroleum exploration has not been as intensive in the Paris-Bannock thrust belt as in the more easterly thrust structures; however, several holes showing some oil and gas have been completed in the past. The Rocky Mountain $0 i 1$ and Gas Association estimates that over 300 million barrels of 0 il and approximately three trillion cubic feet of gas occur in Rare II tracts in this belt. Phosphate resources are minor in comparison with the more easterly belts. Some potential for disseminated gold and base metals in the Precambrian and Lower Paleozoic strata is also present. May be traversed by existing gas pipeline.

GEOLOGY: Paris-Bannock thrust belt (includes terrain between Paris-Bannock fault on east and the Wasatch fault and its northward projection on the west). The Wasatch fault is the major east boundary fault of the Basin and Range structural province and is generally normal in character, usually having a steep westward dip. Bedrock includes strata from the younger Precambrian, all Paleozoic systems, and Tertiary and Quaternary deposits. Tertiary and Quaternary volcanic rocks and similar age gravels locally cover the older rocks and structures.

REFERENCE/CITATION: USFS, 1978, RARE II DES, ID, UT, and WY Suppls.; D0E, 1978, Energy Res. Assessments of RARE II Lands; DOE, 1978, Energy Res. Assessments, of Ten Al.ternatives-RARE II Lands; Powers, 1977, WGA Gdbk 29; Blackstone, 1978, Tectonic Map of the Overthrust Belt: WGS; RMOGA, 1978, Estimates of Undiscovered Recoverable Hydrocarbon Resources (RARE-II); White and Williams, 1975, USGS Circ. 726; NOAA, 1977, Geothermal Energy Resources of the Western U.S.; USGS, 1945, Min. Res. Mo. Valley Region, Pts. 1, 2, 3; ERDA, 1976, NURE-Prelim. Rpt.; Armstrong and Oriel, 1965, AAPG Bull., v. 43; British Sulfur Corp., Ltd., 1964, A World Survey of Phosphate Deposits: Woodalls Ltd. (Printers), London; Gulbrandsen, 1966, Geochim. Cosmochim. Acta, v. 3, p. 769-778; Brobst and Pratt, 1973, USGS Prof. Paper 820; Worl and Others, 1974, USGS MR-60; Kinkel and Peterson, 1962, USGS MR-13; RMAG, 1972, Geologic Atlas of the Rocky Mountain Region: Denver, CO; Stokes and Madsen, 1961, Geologic Map of Utah-Northeast Quarter: UGMS; USGS, 1964, Mineral and Water Resources of Utah: 88th U.S. Congress; White, 1962, USGS MR-20. 
ENERGY AND MINERAL RESOURCE EVALUATION - RARE II TRACTS

TRACT NO: 04764

TRACT NAME: Upper South Fork

ECOREG : 3112

WAR: 20

NATIONAL FOREST: Wasatch

STATE/COUNTY: Utah, Weber

ACREAGE (GROSS): 12,900 ACREAGE (NET): $11,800100 \mathrm{~N} / \mathrm{G}: 91$ LATITUDE: $41^{\circ} 19^{\prime}$ LONGITUDE: $111^{\circ} 32^{\prime}$

INDIVIDUAL TRACT

RESOURCE RATINGS

$\underline{\text { ORNL }} \quad \underline{\text { USFS }} \quad \underline{\text { DOE }} \quad \underline{\text { USGS }}$

REMARKS

OIL ÁND GÄS

$4 / 2 \quad 4 \quad 3$

Stratigraphic and structural traps compounded by thrusting; similar to Canadian Rockies Foothilis Belt

$\begin{array}{llll}\text { UPANIUM } & 2 / 1 & 1 & 1 \\ \text { COAL. } & 1 / 4 & 1 & 1 \\ \text { GEOTHERMAL } & 2 / 2 & 1 & \\ \text { CRITICAL MINERALS } & 4 / 2 & 4 & \\ \begin{array}{l}\text { OVERALL RATING } \\ (\text { WEIGHTED) }\end{array} & 2 & & 3\end{array}$

NAMES OF CRITICAL MINERALS PRESENT: $P(U, V, F, \mathrm{Zn}, \mathrm{Cd}, \mathrm{Cr})$

COMMENTARY AND SUMMARY: Petroleum exploration has not been as intensive in the Paris-Bannock thrust belt as in the more easterly thrust structures; however, several holes showing some oil and gas have been completed in the past. The Rocky Mountain 0il and Gas Association estimates that over 300 million barrels of oil and approximately three trillion cubic feet of gas occur in Rare II tracts in this belt. Phosphate resources are minor in comparison with the more easterly belts. Some potential for disseminated gold and base metals in the Precambrian and Lower Paleozoic strata is also present.

GEỎLOGY: Paris-Bannock thrust belt (includes terrain between Paris-Bannock fault on east and the Wasatch fault and its northward projection on the west). The wasatch fault is the major east boundary fault of the Basin and Range structural province and is generally normal in character, usually having a steep westward dip. Bedrock includes strata from the younger Precambrian, all Paleozoic systems, and Tertiary and Quaternary deposits. Tertiary and Quaternary volcanic rocks and similar age gravels locally cover the older rocks and structures.

REFERENCE/CITATION: USFS, 1978, RARE II DES, ID, UT, and WY Suppls.; D0E, 1978, Energy Res. Assessments of RARE II Lands; DOE, 1978, Energy Res. Assessments, of Ten Alternatives-RARE II Lands; Powers, 1977, WGA Gdbk 29; Blackstone, 1978, Tectonic Map of the Overthrust Belt: WGS; RMOGA, 1978, Estimates of Undiscovered Recoverable Hydrocarbon Resources (RARE-II); White and Williams, 1975, USGS Circ. 726; NOAA, 1977, Geothermal Energy Resources of the Western U.S.; USGS, 1945, Min. Res. Mo. Valley Region, Pts. 1, 2, 3; [RDA, 1976, NURE=Piel iiiil. Ril.; Arlis liurly dild Or.iel, 1965, AAPG Bull., v. 43; Brltlsh Sulfur Corp., Ltd., 1964, A World Survey of Phosphate Deposits: Woodalls Ltd. (Printers), London; Gulbrandsen, 1966, Geochim. Cosmochim. Acta, v. 3, p. 769-778; Brobst and Pratt, 1973, USGS Prof. Paper 820; Worl and Others, 1974, USGS MR-60; Kinkel and Peterson, 1962, USGS MR-13; RMAG, 1972, Geologic Atlas of the Rocky Mountain Region: Denver, CO; Stokes and Madsen, 1961, Geologic Map of Utah-Northeast Quarter: UGMS; USGS, 1964, Mineral and Water Resources of Utah: 88th U.S. Congress; White, 1962, USGS MR-20. 
ENERGY AND MINERAL RESOURCE EVALUATION - RARE II TRACTS

TRACT NO: 04765

TRACT NAME: Burch Creek

ECOREG: 3112

WAR: 19

NATIONAL FOREST: Wasatch

ACREAGE (GROSS): 8,340 ACREAGE (NET): 7,700
STATE/COUNTY: Utah, Weber/Morgan

$100 \mathrm{~N} / \mathrm{G}: 92$ LATITUDE: $41^{\circ} 11^{\prime}$ LONGITUDE: $111^{\circ} 53^{\prime}$
INDIVIDUAL TRACT

RESOURCE RATINGS

OIL AND GAS

$\underline{\text { ORNL }}$

$4 / 1$

USFS

DOE

USGS

OIL AND GAS

URANIUM

COAL

GEOTHERMAL

CRITICAL MINERALS

$2 / 1$

$1 / 4$

$3 / 2$

$2 / 1$

$1^{+}$
1

1

1

1

1
OVERALL RATING

(WEIGHTED)
REMARKS

Stratigraphic and structural traps compounded by thrusting; similar to Canadian Rockies Foothills Belt

NAMES OF CRITICAL MINERALS PRESENT: Base and precious metals?

COMMENTARY AND SUMMARY: Petroleum exploration has not been as intensive in the Paris-Bannock thrust belt as in the more easterly thrust structures; however, several holes showing some oil and gas have been completed in the past. The Rocky Mountain $0 i 1$ and Gas Association estimates that over 300 million barrels of 0 il and approximately three trillion cubic feet of gas occur in Rare II tracts in this belt. Phosphate resources are minor in comparison with the more easterly belts. Some potential for disseminated gold and base metals in the Precambrian and Lower Paleozoic strata is also present.

GEOLOGY: Paris-Bannock thrust belt (includes terrain between Paris-Bannock fault on east and the Wasatch fault and its northward projection on the west). The Wasatch fault is the major east boundary fault of the Basin and Range structural province and is generally normal in character, usually having a steep westward dip. Bedrock includes strata from the younger Precambrian, all Paleozoic systems, and Tertiary and Quaternary deposits. Tertiary and Quaternary volcanic rocks and similar age gravels locally cover the older rocks and structures.

REFERENCE/CITATION: USFS, 1978, RARE II DES, ID, UT, and WY Suppls.; DOE, 1978, Energy Res. Assessments of RARE II Lands; DOE, 1978, Energy Res. Assessments, of Ten Alternatives-RARE II Lands; Powers, 1977, WGA Gdbk 29; Blackstone, 1978, Tectonic Map of the Overthrust Belt: WGS; RMOGA, 1978, Estimates of Undiscovered Recoverable Hydrocarbon Resources (RARE-II); White and Williams, 1975, USGS Circ. 726; NOAA, 1977, Geothermal Energy Resources of the Western U.S.; USGS, 1945, Min. Res. Mo. Valley Region, Pts. 1, 2, 3; ERDA, 1976, NURE-Prelim. Rpt.; Armstrong and Oriel, 1965, AAPG Bull., v. 43; British Sulfur Corp., Ltd., 1964, A World Survey of Phosphate Deposits: Woodalls L.td. (Printers), London; Gulbrandsen, 1966, Geochim. Cosmochim. Acta, v. 3, p. 769-778; Brobst and Pratt, 1973, USGS Prof. Paper 820; Worl and 0thers, 1974, USGS MR-60; Kinkel and Peterson, 1962, USGS MR-13; RMAG, 1972, Geologic Atlas of the Rocky Mountain Region: Denver, CO; Stokes and Madsen, 1961, Geologic Map of Utah-Northeast Quarter: UGMS; USGS, 1964, Mineral and Water Resources of Utah: 88th U.S. Congress; White, 1962, USGS MR-20. 


\section{THIS PAGE}

\section{WAS INTENTIONALLY \\ LEFT BLANK}




\section{EASTERN SECTION}

\subsection{Description of the Central Appalachians}

The central Appalachians studied in the second application are shown in Fig. 3. The region lies within a 330 - by $100-m i l e ~ b e l t$ paralleling the regional geologic structure and encompasses large parts of Virginia, West Virginia, North Carolina, and Tennessee. The area comprises approximately 33,000 sq miles, or about $21,100,000$ acres, and contains 72 RARE II tracts totalling about 610,000 acres. Figure 1 illustrates the relatively small size. of the central Appalachian tracts as compared with the Idaho-Wyoming-Utah thrust belt.

The central Appalachians include three relatively distinct northeast-trending physiographic provinces, which correspond roughly to geologic/structural provinces (Fenneman 1946). Along the southeast site is the Blue Ridge province, which consists largely of Precambrian igneous and metamorphic rocks and smaller amounts of Paleozoic sedimentary rocks. Fifteen tracts are located in the metamorphic and igneous eastern part of the province, and fourteen are located in the sedimentary rocks on the western edge. Adjacent to the Blue Ridge to the northwest is the Valley and Ridge province, which consists of Lower and Middle Paleozoic sedi- mentary rocks. Thirty-four tracts are located in this province. Immediately northwest of the Valley and Ridge is the Appalachian Plateau province, which consists of Middle and Upper Paleozoic sedimentary rocks. Nine tracts are included in this province.

All three provinces have been deformed as a result of late $\mathrm{Paleozoic}$ compression directed to the northwest (Harris and Milici 1977). The compression has formed abundant folds and thrust faults, particulariy in the Valley and Ridge. In general, thrust faults are the dominant structures at the surface in the southern and eastern parts of the province, whereas the northern and western segments are characterized by large fold structures with only nominal faulting. These parts of the province are informally called thrust fault-dominated and folddominated, respectively, in this report. Eleven tracts are located in the thrust-dominated area, and twenty-three tracts are located in the folddominated area. In the Appalachian Plateau, the compressional deformation is much less severe,although large folds and areally extensive thrust sheets have been recognized. To the east, the intensity of deformation increases, and metamorphic effects are widespread, especially in the Blue Ridge. 
ORNL-DWG 79-7244 R

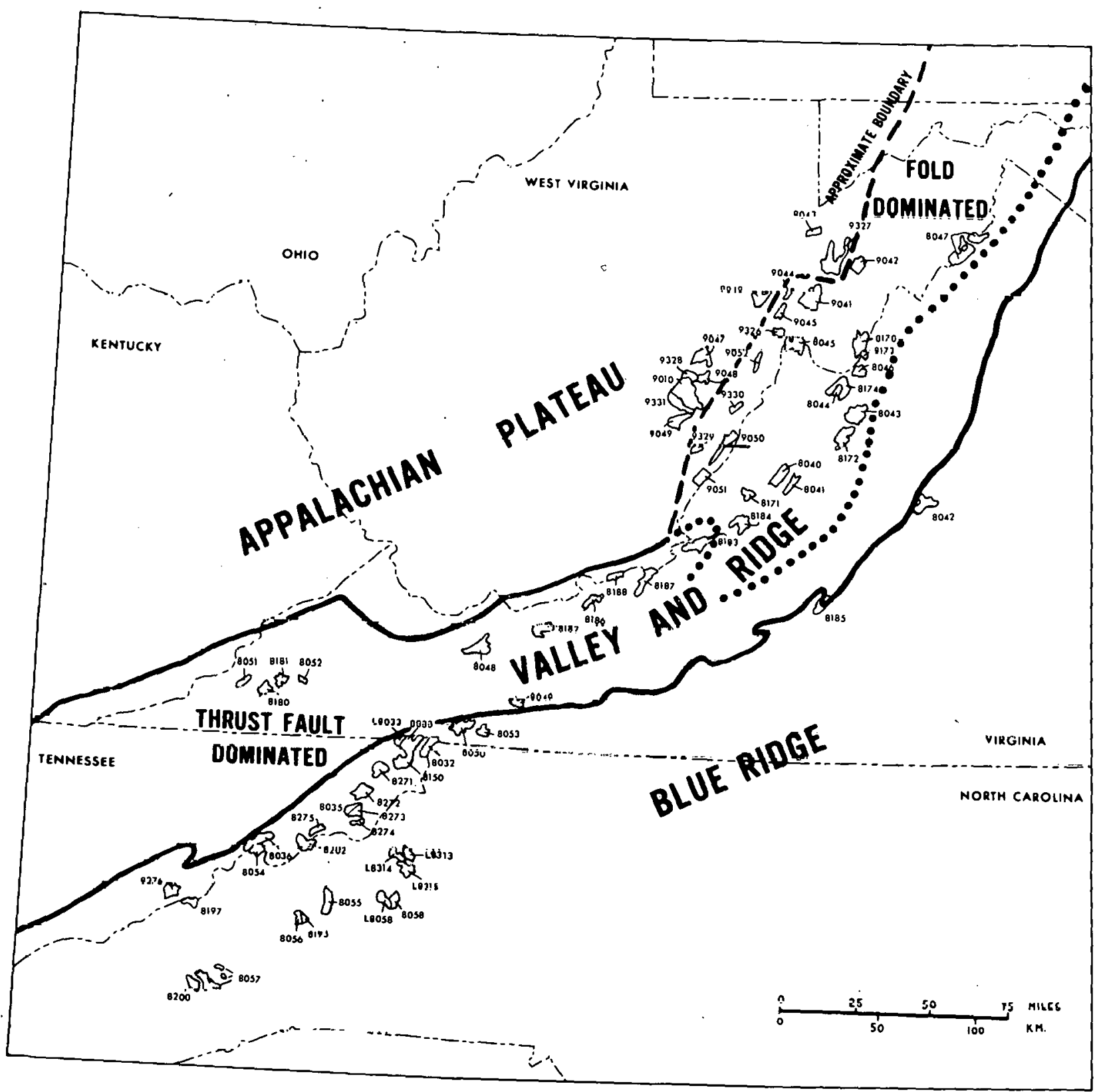

Fig. 3. RARE II tracts in the central Appalachian thrust belt. 
3.2 Assessment Forms for Central Appalachian Thrust Belt 


\section{THIS PAGE}

WAS INTENTIONALLY

LEFT BLANK 
ENERGY AND MINERAL RESOURCE EVALUATION - RARE II TRACTS

TRACT N0: 08032

TRACT NAME: Rodgers Ridge

ECOREG : 2214

WAR: 15

NATIONAL FOREST: Cherokee

STATE/COUNTY: Tennessee, Johnson

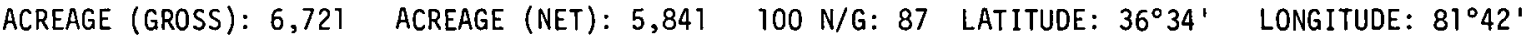

INDIVIDUAL TRACT

RESOURCE RATINGS

ORNL USFS DOE USGS

REMARKS

OIL AND GAS

$3 / 1 \quad 1$

URAN IUM

$2 / 2$

1

2

NURE favorable area (ERDA 1976)

COAL

GEOTHERMAL

$1 / 4$

1

CRITICAL MINERALS $\quad 4 / 4 \quad 1$

OVERALL RATING

(WEIGHTED)

3

NAMES OF CRITICAL MINERALS PRESENT: Manganese; possible iron, zinc, lead, and barite

COMMENTARY AND SUMMARY: This tract is in the Hot Springs Window of the Blue Ridge province. The rocks below the basal Blue Ridge Thrust may be favorable for gas (Harris 1976). The tract is within an area classified as favorable for uranium by NURE (ERDA 1976). The rocks are too old for coal. Hot dry rock at depth may be favorable as a source of geothermal energy. The mineral environment is similar to that of the Hot Springs Barite District, N.C. (Oriel 1950), so that the rocks are favorable for barite, iron, and manganese. Little exploration has occurred for any resources in the immediate area.

GEOLOGY: The Precambrian Rogers Volcanic Group underlies the northeast part of the tract, and Lower Cambrian shales, Sandstones, and carbonates of the Unicoi, Hampton, Erwin and Shady formations of the Johnson County Cove Window underlie the rest.

REFERENCE/CITATION: All resources - Hardeman and Others, 1966, Geol. Map of Tenn.; USGS and USBM, 1968, USGS Prof. Paper 580; Miller and Others, 1970, Mineral Res. of the TVA Region; Brobst and Pratt, 1973, USGS Prof. Paper 820; DOE, 1978, Energy Res. Assessments of RARE II Lands; D0E, 1978, Energy Res. Assessments of Ten Alternatives - RARE II Lands; USFS, 1978, RARE II DES, So. Appal. Suppl. 0il and Gas - VIissides and Quirin, 1963, 0il and Gas Fields of the U.S.; Cardwe11, 1971, AAPG Mem. 15; USGS, $\overline{1974}$ and 1975, Maps of Appal. Oil and Gas Production; Miller and Others, 1975, USGS Circ. 725; Harris, 1976, J. Res. USGS, v. 4, no. 4; Harris and Milici, 1977, USGS Prof. Paper 1018; Van Den Berg and 0thers, 1978, AAPG Bu11. 62: 1340-55. Uranium - ERDA, 1976, NURE Preliminary Report. Coal - Trumbu11, 1960, Coal Fields of the U.S. Geothermal - AAPG, 1976a and b, Geothermal Gradient Map and Subsurface Temperature Map of North Am. Critical Minerals - King and Ferguson, 1960, USGS Prof. Paper 311. 
ENERGY AND MINERAL RESOURCE EVALUATION - RARE II TRACTS

TRACT N0: 08033

NATIONAL FOREST: Cherokee
TRACT NAME: Beaverdam Creek

ECOREG : 2214

WAR: 17
ACREAGE (GROSS): 4,900 ACREAGE (NET) : 4,900 $100 \mathrm{~N} / \mathrm{G}: 100$ LATITUDE: $36^{\circ} 36^{\prime}$ LONGITUDE: $81^{\circ} 52^{\prime}$

INDIVIDUAL TRACT

RESOURCE RATINGS

ORNL

$\underline{\text { USFS }}$

$\underline{\mathrm{DOE}}$

$\underline{\text { USGS }}$

REMARKS

OIL AND GAS

$3 / 1$

1

URANIUM

$2 / 1$

1

2

COAL

GEOTHERMAL

$1 / 4$

1

1

CRITICAL MINERALS

$4 / 4$

1

OVERALL RATING

(WEIGHTED)

3-

Shady Valley Manganese District (King and rergusún 1960)

NAMES OF CRITICAL MINERALS PRESENT: Manganese and iron; possible zinc, lead, and barite

COMMENTARY AND SUMMARY: This tract is in the Blue Ridge province. The rocks may be favorable for gas at depth below the basal Blue Ridge Thrust (Harris 1976). Sandstone and conglomerate units may be favorable for uranium. The rocks are too old for coal. Hot dry rock at depth may be favorable as a source of geothermal energy. The weathered Shady Dolomite contains mined deposits of manganese and iron ore and is quite favorable for zinc, lead, and barite (King and Ferguson 1960). Except for critical minerals, little exploration for resources has occurred.

GEOLOGY: Surface rocks are the Lower Cambrian shales, sandstones, and carbonates of the Unicoi through Shady formations on the NW flank of the Shady Valley Syncline.

REFERENCE/CITATION: All resources - Hardeman and Others, 1966, Geol. Map of Tenn.; USGS and USBM, 1968, USGS Prof. Paper 580; Miller and 0thers, 1970, Mineral Res. of the TVA Region; Brobst and Pratt, 1973, USGS Prof. Paper 820; D0E, 1978, Energy Res. Assessments of RARE II Lands; DOE, 1978, Energy Res. Assessments of Ten Alternatives - RARE II Lands; USFS, 1978, RARE II DES, So. Appal. Suppl. 0il and Gas - Vlissides and Quirin, 1963, 0il and Gas Fields of the U.S.; Cardwe11, 1971, AAPG Mem. 15; USGS, 1974 and 1975, Maps of Appar. 0 i1 and Gas Production; Miller and Others, 1975, USGS Circ. 725; Harris, 1976, J. Res. USGS, v. 4, no. 4; Harris and Milici, 1977, USGS Prof. Paper 1018; Van Den Berg and 0thers, 1978, AAPG Bu117. 62: 1340-55. Uranium - ERDA. 1976. NURE Prel iminary Repnrt.. Conal - Trumhu11, 1960, Coal Fields of the U.S. Geothermal-AAPG, 1976 a and b, Geothermal Gradient Map and Subsurface Temperature Map of North Am. Critical Minerals - King and Ferguson, 1960, USGS Prof. Paper 311. 
ENERGY AND MINERAL RESOURCE EVALUATION - RARE II TRACTS

TRACT N0: $L 8033$

NATIONAL FOREST: Cherokee

ACREAGE (GROSS): 2,000
TRACT NAME: Beaver Dam Creek

ECOREG: 2214

WAR: 15

STATE/COUNTY: Tennessee, SUl1ivan

ACREAGE (NET) : $2,000100 \mathrm{~N} / \mathrm{G}: 100$ LATITUDE: $36^{\circ} 33^{\prime}$ LONGITUDE: $82^{\circ} 40^{\circ}$

\begin{tabular}{lcccc}
$\begin{array}{l}\text { INDIVIDUAL TRACT } \\
\text { RESOURCE RATINGS }\end{array}$ & ORNL & USFS & DOE & USGS \\
\cline { 1 - 2 } OIL AND GAS & $3 / 1$ & 1 & & \\
URANIUM & $2 / 1$ & 1 & 2 \\
COAL & $1 / 4$ & 1 & 1 \\
$\begin{array}{l}\text { GEOTHERMAL } \\
\text { CRITICAL MINERALS }\end{array}$ & $3 / 2$ & 1 & \\
$\begin{array}{l}\text { OVERALL RATING } \\
\text { (WEIGHTED) }\end{array}$ & $2-$ & &
\end{tabular}

possible shady residuum; near Shady Valley manganese district (King and Ferguson 1960)

NAMES OF CRITICAL MINERALS PRESENT: Possible manganese, iron, zinc, lead, and barite

COMMENTARY AND SUMMARY: This tract is in the Blue Ridge province. The rocks at depth below the basal Blue Ridge Thrust may be favorable for gas (Harris 1976). Sandstone and conglomerate units may be favorable for uranium. The rocks are too old for coal. Hot dry rock at depth may be favorable as a source of geothermal energy. Iron, manganese, zinc, lead, and barite may exist in unmapped residuum of Shady Dolomite (King and Ferguson 1960), but the unit has been completely eroded from the tract. Except for critical minerals, little exploration has occurred for resources in the immediate area.

GEOLOGY: Surface rocks are Lower Cambrian Unicoi and Hampton Shales and Sandstones on NW flank of Shady Valley Syncline.

REFERENCE/CITATION: All resources - Hardeman and Others, 1966, Geol. Map of Tenn.; USGS and USBM, 1968, USGS Prof. Paper 580; Miller and Others, 1970, Mineral Res. of the TVA Region; Brobst and Pratt, 1973, USGS Prof. Paper 820; DOE, 1978, Energy Res. Assessments of RARE II Lands; DOE, 1978, Energy Res.

As sessments of Ten Alternatives - RARE II Lands; USFS, 1978, RARE II DES, So. Appal. SuppI. 0il and Gas - Vlissides and Quirin, 1963, 0il and Gas Fields of the U.S.; Cardwell, 1971, AAPG Mem. 15; USGS, $\overline{1974}$ and 1975, Maps of Appal. 011 and Gas Production; Miller and 0thers, 1975, USGS Circ. 725; Harris, 1976, J. Res. USGS, v. 4, no. 4; Harris and Milici, 1977, USGS Prof. Paper 1018; Van Den Berg and 0thers, 1978, AAPG Bu11. 62: 1340-55. Uranium - ERDA, 1976,. NURE Preliminary Report. Coal - Trumbu11, 1960, Coal Fields of the U.S. Geothermal-AAPG, 1976a and b, Geothermal Gradient Map and Subsurface Temperature Map of North Am. Critical Minerals - King and Ferguson; 1960, USGS Prof. Paper 311. 
INDIVIDUAL TRACT P.ESOURCE RATINGS

ORNL USFS DOE USCS

OIL AND GAS

URANIUINI

$2 / 1$

$2 / 2$

$$
1
$$

COAL

$1 / 4$

GEOTHERMAL

$2 / 1$

CRITICAL MINERALS

$4 / 4$

1
REMARK'S

OVERALL RATING

(WEIGHTED)

$3^{-}$

NAMES OF CRITICAL MINERALS PRESENT: Iron and manganese; possible zinc, lead, and barite.

COMMENTARY AND SUMMARY: This tract is in the Blue Ridge province. Possible sedimentary rocks below the basal Biue Ridge Thrust may be favorable for gas (Harris 1976). The Precambrian igneous rocks may be favorable for uranium. The rocks are too old for coal. Hot dry rock at depth may be favorable as a source of geothermal energy. The weathered Shady Dolomite contains mined deposits of iron and manganese and is favorable for zinc, lead, and barite (King and Ferguson 1960). In the immediate area. ilttle exploration tor any resources except critical minerals has occurred.

GEOLOGY: Surface rocks are the Lower Cambrian shales, sandstones, and carbonates of the Unicoi, Hampton, Erwin, and Shady formations within the Doe River Cove Window and Precambrian igneous rock along the southwest edge of the tract.

REFERENCE/CITATION: A11 resources - Hardeman and Others, 1966, Geol. Map of Tenn.; USGS and USBM, 1968, USGS Prof. Paper 580; Miller and 0thers, 1970, Mineral Res. of the TVA Region; Brobst and Pratt, 1973, USGS Prof. Paper 820; DOE, 1978, Energy Res. Assessments of RARE II Lands; DOE, 1978, Energy Res. Assessments of Ten Alternatives - RARE II Lands; USFS, 1978, RARE II DES, So. Appal. Suppl. 0il and Gas - Vlissides and Quirin, 1963, 0il and Gas Fields of the U.S.; Cardwe11, 1971, AAPG Mem. 15; USGS, 1974 and 1975, Maps of Appal. 0 il and Gas Production; Miller and Others, 1975, USGS Circ. 725; Harris, 1976, J. Res. USGS, v. 4, no. 4; Harris and Milici, 1977, USGS Prof. Paper 1018; Van Den Berg and Others, 1978, AAPG Bu11. 62: 1340-55. Uranium - ERDA, 1976, NURE Prel iminary Report. Coal - Trumbu11, 1960, Coal Fields of the U.S. Geothermal-AAPG, 1976a and b, Geothermal Gradient Map and Subsurface Temperature Map of North Am. Critical Minerals - King and Ferguson, 1960, USGS Prof. Paper 311. 
ENERGY AND MINERAL RESOURCE EVALUATION - RARE II TRACTS

TRACT NO: 08036

TRACT NAME: Jennings Creek

ECOREG: 2214

WAR: 21

NATIONAL FOREST: Cherokee

STATE/COUNTY: Tennessee, Greene/Washington/Uni.coi

ACREAGE (GROSS): 14,700 ACREAGE (NET): $12,500100 \mathrm{~N} / \mathrm{G}: 85$ LATITUDE: $36^{\circ} 07^{\prime}$ LONGITUDE: $82^{\circ} 40^{\prime}$

INDIVIDUAL TRACT

RESOURCE RATINGS

$\underline{\text { ORN }}$

USFS

$\underline{D O E} \quad \underline{U S G S}$

REMARKS

OIL AND GAS

$3 / 1 \quad 1$

URANIUM

$2 / 2 \quad 1$

COAL

$1 / 4 \quad 1$

GEOTHERMAL

$2 / 1 \quad 1$

CRITICAL MINERALS

$3 / 2$

1

Possible Shady residuum

OVERALL RATING

(WEIGHTED) $\quad 2^{+}$

NAMES OF CRITICAL MINERALS PRESENT: POSs1ble manganese, iron, lead, zinc, and barite

COMMENTARY AND SUMMARY: This tract is in the Blue Ridge province. The rocks at depth below. the basal Blue Ridge Thrust may be favorable for gas (Harris 1976). Sandstone and conglomerate units may be favorable for uranium. The rocks are too old for coal. Hot dry rock at depth may be favorable as a source of geothermal energy. Iron, manganese, zinc, lead, and barite may exist in unmapped residuum of Shady Dolomite (King and Ferguson 1960), but the unit has been completely eroded from the tract. Except for critical minerals, little exploration has occurred for resources in the immediate area.

GEOLOGY: Surface rocks are the Lower Cambrian shales as well as sandstones of the Unicoi, Hampton, and Erwin formations.

REFERENCE/CITATION: $\Lambda 11$ resources = Hardeman and 0thers, 1966, Geol. Map of Tenn.; USGS and USBM, 1968, USGS Prof. Paper 580; Miller and Others, 1970, Mineral Res. of the TVA Region; Brobst and Pratt, 1973, USGS Prof. Paper 820; D0E, 1978, Energy Res. Assessments of RARE II Lands; D0E, 1978, Energy Res. Assessments of Ten Alternatives - RARE II Lands; USFS, 1978, RARE II DES, So. Appal. Suppl. 0i1 and Gas - V1issides and Quirin, 1963, 011 and Gas Fields of the.U.S.; Cardwe11, 1971, AAPG Mem. 15; USGS, $\overline{1974}$ and 1975, Maps of Appal. Oil and Gas Production; Miller and Others, 1975, USGS Circ. 725; Harris, 1976, J. Res. USGS, v. 4, no. 4; Harris and Milici, 1977, USGS Prof. Paper 1018; Van Den Berg and 0thers, 1978, AAPG Bu11. 62: 1340-55. Uranium - ERDA, 1976, NURE Preliminary Report. Coal - Trumbul1, 1960, Coal Fields of the U.S. Geothermal-AAPG, 1976a and b, Geothermal Gradient Map and Subsurface Temperature Map of North Am. Crit.ical Minerals - King and Ferguson, 1960, USGS Prof. Paper 311. 
ENERGY AND MINERAL RESOURCE EVALUATION - RARE II TRACTS

TRACT NO: 08040

TRACT NAME: Rough Mountain

ECOREG : 2214

WAR: 20

NATIONAL FOREST: George Washington

STATE/COUNTY: Virginia, Bath

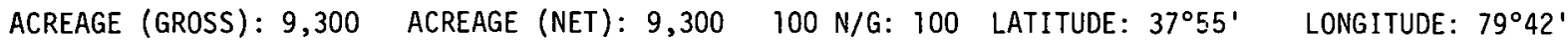

INDIVIDUAL TRACT

RESOURCE RATINGS

\begin{tabular}{|c|c|}
\hline RESOURCE RATINGS & $\underline{\text { ORNL }}$ \\
\hline OIL AND GAS & $3 / 2$ \\
\hline UIRAN IIIM & $2 / 1$ \\
\hline C.nAl & $1 / 4$ \\
\hline GEOTHERMAL & $2 / 2$ \\
\hline CRITICAL MINERALS & $.3 / 3$ \\
\hline $\begin{array}{l}\text { OVERALL RATING } \\
\text { (WEIGHTED) }\end{array}$ & 2 \\
\hline
\end{tabular}

DOE USGS

REMARKS

Hear an area with warm springs

Along strike of a bclt of manganese deposits in Bath County

NAMES OF CRITICAL MINERALS PRESENT: Probable copper; cadmium possible; iron, zinc, lead, fluorite, phosphate, and barite at depth.

COMMENTARY AND SUMMARY: This tract is in the fold-dominatcd part of the Valley and Ridge province. The rocks are quite favorable for oil and gas, al though some hydrocarbons may have been driven off by heat from metamorphism and igneous activity in the nearby Blue Ridge, heat that also made gas more common than oil throughout the province. These hydrocarbons are produced in several places in the province in the study area. Sandstone units may be favorable for uranium. The rocks are ton nld t.n contain coal. Warm springs in the area suggest that there is potential for geothermal energy. The Upper Devonian red beds at the surface may contain the critical mineral copper. Critical minerals for which the subsurface rocks may be favorable include zinc and lead (Devonian Oriskany Sandstone); iron (Silurian Clinton Formation); and zinc, lead, cadmium, fluorite, and barite (Ordovician carbonates). Little exploration for any commodity has occurred except for oil and gas, which has been only moderate.

GEOLOGY: Surface rocks are Upper Uevonian shales and sandstones folded into several gentle anticlines and synclines.

REFERENCE/CITATION: All resources - Milici and Others, 1963, Geol. Map of Va.; Gooch and Pharr, 1959, Mineral Indus. and ReS. Of Va.; USGS and USBM, 1968, USGS Prof. Paper 580; Miller and Others, 1970, Mineral Res. of the TVA Region: Brobst and Pratt, 197.3, IISGS.S Prof. Paper 820; DOE, 1978, Energy Res. Assessments of RARE II Lands; DOE, 1978, Energy Res. Assessments of Ten ATternatives - RARE II Lands; USFS, 1978, RARE II DES, So. Appai. Suppl. 0il and Gas - Vlissides and Quirin, 1963, 0il and Gas Fields of the U.S.; Cardwel1, 1971. AAPG Mem. 15; USGS, 1974 and 1975, Maps of Appal: 0il and Gas Production; Miller and Others, 1975, USGS Circ. 725; Harris and Milici, 1977, USGS Prof. Paper 1C.18; Patchen and Others, 1978, AAPG Bu11. 8. Uranium - ERDA, 1976, NURE Preliminary Report. Coal Trumbul1, 1960, Coal Fields of the U.S. Geothermal - AAPG, 1976a and b, Geothermal Gradient Map and Subsurt. lemp. Map of N. Am. Critical Minerals - Lesure, 1957, V.P.I. Bul1., Eng. Expt. Sta. series 118; Worl and Others, 1968, Fluorite Deposits of the U.S.; Lesure and Others, 1978, U.S.G.S. BuI1. $1397 \mathrm{c}$. 


\begin{tabular}{|c|c|c|c|c|}
\hline $\begin{array}{l}\text { INDIVIDUNL TRACT } \\
\text { RESOURCE RATINGS }\end{array}$ & ORNL & USFS & DOE & USGS \\
\hline OIL AND GAS & $3 / 2$ & 1 & & \\
\hline URANIUM & $2 / 1$ & 1 & & \\
\hline COAL & $1 / 4$ & 1 & & \\
\hline GEOTHERMAL & $2 / 1$ & 1 & & \\
\hline CRITICAL MINERALS & $2 / 2$ & 1 & & \\
\hline $\begin{array}{l}\text { OVERALL RATING } \\
\text { (WEIGHTED) }\end{array}$ & $1^{\top}$ & & & \\
\hline
\end{tabular}

NAMES OF CRITICAL MINERALS PRESENT: Possible manganese, iron, and zinc; possible cadmium, zinc, lead, fluorite, and barite at depth

COMMENTARY AND SUMMARY: This tract is in the fold-dominated part of the Valley and Ridge province. The rocks are quite favorable for $0 i 1$ and gas, although some hydrocarbons may have been driven off by heat from metamorphism and igneous activity in the nearby Blue Ridge, heat that also made gas more common than oil throughout the province. These hydrocarbons are produced in several places in the province in the study area. Sandstone units may be favorable for uranium. The rocks are too old to contain coal. Hot dry rock at depth may have some potential for geothermal energy. The Devonian Oriskany Sandstone at the surface may contain critical minerals manganese, iron, and zinc, and the Silurian clinton Formation may contain iron. Critical minerals for which the subsurface rocks may be favorable incluae zinc, lead, cadmium, fluorite, and barite (Ordovician carbonates). Little exploration has occurred for any commodity, except for oil and gas for which exploration has been moderate.

GEOLOGY: Surface rocks are Silurian and Lower to Middle Devonian shales and sandstones along the southeast flank of an anticline.

REFERENCE/CITATION: All resources - Milici and Others, 1963, Geol. Map of Va.; Gooch and Pharr, 1959, Mineral Indus. and ReS. of Va.; USGS and USBM, 1968, USGS Prof. Paper 580; Miller and 0thers, 1970, Mineral Res. of the TVA Region; Brobst and Pratt, 1973, USGS Prof. Paper 820; DOE, 1978, Energy Res. Assessments of RARE II Lands; DOE, 1978, Energy Res. Assessments of Ten A1ternatives - RARE II Lands; USFS, 1978, RAP.E II DES, So. Appal. Suppl. 0il and GaS - V1issides and Quirin, 1963, 0i1 and Gas Fields of the U.S.; Cardwel1, 1971, AAPG Mem. 15; IISGS, 1974 and 1975, Maps of Appal. 0il and Gas Production; Miller and 0thers, 1975, USGS Circ. 725; Harris and Milici, 1977, USGS Prof. Paper 1018; Patchen and Others, 1978, AAPG Bul1 . 8. Uranium - ERDA, 1976, NURE Preliminary Report. Coal Trumbul1, 1960, Coal Fields of the U.S. Geothermal - AAPG, 1976a and b, Geothermal Gradient Map and Subsurf. Temp. Map of N. Am. Critical Minerals-Lesure, 1957, V.P.I. Bul1., Eng. Expt. Sta. series 118; Worl and Others, 1968, Fluorite Deposits of the U.S.; Lesure and Others, 1978, U.S.G.S. Bull. $1397 c$. 


$\begin{array}{lcc}\text { OTI. AND GAS } & 2 / 1 & 1 \\ \text { URANIUM } & 2 / 1 & 1 \\ \text { COAL } & 1 / 4 & 1 \\ \text { GEOTHERMAL } & 2 / 1 & 1 \\ \begin{array}{l}\text { CRITICAL MINERALS } \\ \text { OVFRAII. RATING } \\ \text { (WEIGHTED) }\end{array} & 3 / 2 & 1 \\ & & \end{array}$

Along strike of mined manganese deposits. Irish Creek tin deposit 5 miles south (Goosh and Pharr lysy)

NAMES OF CRITICAL MINERALS PRESENT: Possible manganese, zinc, lead, and tin

COMMENTARY AND SUMMARY: This tract is in the Blue Ridge province. Rocks at depth below the basal Blue Ridge Thrust may be favorable for gas (Harris 1976). The basal Cambrian clastics may be favorable for uranium. The rocks are too old for coal. Hot dry rock at depth may be favorable as a source of geothermal eneray. Possible critical minerals include manganese, zinc, lead, and barite in the basal clastics and tin in the gneiss if the Irish creek tin deposit extends to the tract from tive miles south along strike (Gooch and Pharr 1959). Little explorativil has occurred in the immediate area for any resources except for critical resources.

GEOLOGY: Surface rocks are the Precambrian Pedlar Gneiss and the Cambrian sedimentary and metasedimeritary Chilhowee Group, strongly folded and thrust faulted.

REFERENCE/CITATION: All resources - Milici and Others, 1963, Geol. Map of Va.; Gooch and Pharr, 1959, Mineral Indus. and Res. of Va.; USGS and USBM, 1968, USGS Prof. Paper 580; Miller and 0thers, 1970, Mineral Res. of the TVA Region; Brobst and Pratt,. 1973, USGS Prof. Paper 820; DOE, 1978, Energy Res. Assessments of RARE II Lands; DOE, 1978, Energy Res. Assessments of Ten Alternatives - RARE II Lands; USFS, 1978, RARE II DES, So. Appal. Suppl. Oil and GaS - VIissides and Quirin, 1963, $0 i 1$ and Gas Fields of the U.S.; Cardwel1, 1971, AAPG Mem. 15; USGS, 1974 and 1975, Maps of Appal. 0il and Gas Production; Miller and 0thers, 1975, USGS Circ. 725; Harris and Milici, 1977, USGS Prof. Paper 1018; Patchen and Others, 1978, AAPG Bu11. 8. Uranium - ERDA, 1976, NURE Preliminary RepurL. CUdT Trumbu11, 1960, Coal Fields of the U.S. Geothermal - AAPG, 1976a and D, Geothermal Gradient Map and Subsurf. Temp. Map of N. Am. Critical Minerals-Lesure, 1957, V.P.I. Bull., Eng. Expt. Sta. series 118; Worl and Others, 1968, Fluorite Deposits of the U.S.; Lesure and Others, 1978, U.S.G.S. BuI1. $1397 \mathrm{c}$. 
ENERGY AND MINERAL RESOURCE EVALUATION - RARE II TRACTS

TRACT NO: 08043

TRACT NAME: Crawford Mountain

ECOREG : 2214

WAR: 21

NATIONAL FOREST: George Washington

STATE/COUNTY: Virginia, Augusta

ACREAGE (GROSS): 15,360 ACREAGE (NET): $15,360100 \mathrm{~N} / \mathrm{G}: 100$ LATITUDE: $38^{\circ} 19^{\prime} \quad$ LONGITUDE: $79^{\circ} 16^{\prime}$

INDIVIDUAL TRACT

RESOURCE RATINGS

$\underline{\text { ORNL }} \quad \underline{\text { USFS }} \quad \underline{\mathrm{DOE}} \quad \underline{\text { USGS }}$

REMARKS

OIL ANO GAS

$3 / 2 \quad 1$

UIRANIUM

$2 / 1 \quad 1$

CGAL

$1 / 4 \quad 1$

GEOTHERMAL

$2 / 1$

CRITICAL MINERALS

$2 / 1$

1

OVERALL RATING

(WF TGHTED)

NAMES OF CRITICAL MINERALS PRESENT: Possible copper; possible manganese, iron, zinc, lead, cadmium, barite, and fluorite at depth

COMMENTARY AND SUMMARY: This tract is in the fold-dominated Valley and Ridge. The rocks are quite favorable for oil and gas, although some hydrocarbons may have been driven off by heat from metamorphism and igneous activity in the nearby Blue Ridge, heat that also made gas more common than oil throughout the province. These hydrocarbons are produced in several places in the province in the study area. Sandstone units may be favorable for uranium. The rocks are too old to contain coal. Hot dry rock at depth may have some potential for geothermal energy. Upper Devonian red beds may. contain the critical mineral copper. Criticial minerals for which the subsurface rccks may be favorable include zinc and lead (Devonian Oriskany Sandstone); iron (Devonian Helderberg Limestone and Silurian Clinton Formation); and zinc, cadmium, lead, fluorite, and barite (Ordovician carbonates). In the vicinity of the tract, little exploration has occurred except for $0 i 1$ and gas, for which exploration has been moderate.

GEOLOGY: Surface rocks are Upper Devonian and Lower Mississippian shales and sandstones synclinally folded.

REFERENCE/CITATION: All resources - Milici and Others, 1963, Geol. Map of Va.; Gooch and Pharr, 1959, Mineral Indus, and Res. of Va.; USGS and USBM, 1968, USGS Prof. Paper 580; Miller and Others, 1970, Mineral Res. of the 'I'VA Kegion; Brobst and Pratt, 19\%3, USGS Prof. Paper 820; DOE, 1978, Energy Res. Assessments of RARE II Lands; DOE, 1978, Energy Res. Assessments of Ten Alternatives - RARE II Lands; USFS, 1978, RARE II DES, So. Appal. Suppl. 0 il and Gas - V1 issides and Quirin, 1963, 0 il and Gas Fields of the U.S.; Cardwel1, 1971, AAPG Mem. 15; USGS, 1974 and 1975, Maps of Appal. 0il and Gas Production; Miller and Others, 1975, USGS Circ. 725; Harris and Milici, 1977, USGS Prof. Paper 1018; Patchen and 0thers, 1978, AAPG Bu11.8. Uranium - ERDA, 1976, NURE Prel iminary Report. Coal -

Trumbu11, 1960, Coal Fields of the U.S. Geothermal - AAPG, 1976a and b, Geothermal Gradient Map and Subsurf. Temp. Map of N. Am. Critical Minerals-Lesure, i957, V.P.I. Bu11., Eng. Expt. Sta. series 118; Worl and Others, 1968, Fluorite Deposits of the U.S.; Lesure and Others, 1978, U.S.G.S. Bull. $1397 \mathrm{c}$. 
ENERGY AND MINERAL RESOURCE EVALUATION - RARE II TRACTS

TRACT NO: 08044

TRACT NAME: Ramseys Draft Study Area

ECOREG: 2214

WAR: 23

NATIONAL FOREST: George Washington

STATE/COUNTY: Virginia, Highland/Augusta

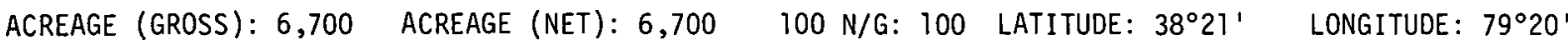

INDIVIDUAL TRACT

RESOURCE RATINGS

$\begin{array}{ccc}\text { ORNL } & & \text { USFS } \\ 3 / 2 & & 1 \\ 2 / 1 & 1 \\ 1 / 4 & 1 \\ 2 / 1 & 1 \\ 3 / 2 & 1 \\ & \\ 2- & \end{array}$

DOE USGS

REMARKS

ÖIL AND GAS

i

URANIUM

1

COAL

1

GLOTIILRMNL 1

CRITICAL MINERALS $3 / 2 \quad 1$

Possibly mineral-bearing rocks are at

OVERALL RATING

(WEIGHTED)

$2^{-}$

NAMES OF CRITICAL MINERALS PRESENT: Possible copper; possible manganese, iron, zinc, lead, cadmium, fluorite, and barite at depth

COMMENTARY AND SUMMARY: This tract is in the fold-dominated Valley and Ridge. The rocks are quite favorabie for oil and gas, although some hydrocaroons may have been drivell off by hed prum illela= morphism and igneous activity in the nearby Blue Ridge, heat that also made gas more common than oil throughout the province. These hydrocarbons are produced in several places in the province in the study area. Sandstone units may be favorable for uranium. The rocks are too old to contain coal. Hot dry rock at depth may have some potential for geothermal energy. Upper Devonian red beds may contain the critical mineral copper. Criticial minerals for which the subsurface rocks may be favorable include zinc and lead (Devonian Oriskany Sandstone); iron (Uevoniann Helderberg Limestone and Sllurlan clinton Formation); and zinc, cadmium, lead, fluorite, and barite (Ordovician carbonates). In the vicinity of the tract, little exploration has occurred except for oil and gas, for which exploration has been moderate.

GEOLOGY: Surface rocks are Upper Devonian shales and sandstones, syncilinally folded.

REFERENCE/CITATIÖN: All resources - Milici and Uthers, lyb3, liéöl. Map of Va.; Gooch and Phar'r, 1959, Mineral Indus. and Res. of Va.; USGS and USBM, 1968, USGS Prof. Paper 580; Miller and 0thers, 1970, Mineral Res. of the TVA Region; Brobst and Pratt, 1973, USGS Prof. Paper 820; D0E, 1978, Energy Res. Assessments of RARE II Lands; DOE, 1978, Energy Res. Assessments of T'en Alternatives - RARE II Lands;

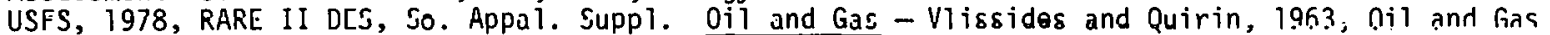
Fields of the U.S.; Cardwe11, 1971, AAPG Mem. 15; USGS, 1974 and 1975, Maps of Appal. 0i1 and Gas Production; Miller and 0thers, 1975, USGS Circ. 725; Harris and Mi1ici, 1977, USGS Prof. Paper 1018; Patchen and 0thers, 1978, AAPG Bu11. 8. Uranium - ERDA, 1976, NURE Prel iminary Report: Coal Trumbu11, 1960, Coal Fields of the U.S. Geothermal - AAPG, 1976a and b, Geothermal Gradient Map and Subsurf. Temp. Map of N. Am. Critical Minerals-Lesure, 1957, V.P.I. Bull., Eng. Expt. Sta. series 118; Worl and Others, 1968 , Fluorite Deposits of the U.S.; Lesure and Others, 1978, U.S.G.S. Bul1. $1397 \mathrm{c}$. 
ENERGY AND MINERAL RESOURCE EVALUATION - RARE II TRACTS

TRACT NO: 08045

TRACT NAME: Laure] Fork

ECOREG : 2214

WAR: 21

NATIONAL FOREST: Monongahela

STATE/COUNTY: Virginia/West Virginia, Highland/Pendleton

ACREAGE (GROSS): 10,965 ACREAGE (NET): $10,965 \quad 100 \mathrm{~N} / \mathrm{G}: 100$ LATITUDE: $38^{\circ} 33^{\prime}$

LONGITUDE: $79^{\circ} 37^{\prime}$

INDIVIDUAL TRACT

RESOURCE RATINGS

\begin{tabular}{|c|c|}
\hline RESOURCE RATINGS & ORNL \\
\hline OIL AND GAS & $3 / 2$ \\
\hline URANIUM & $2 / 1$ \\
\hline COAL & $1 / 4$ \\
\hline GF.OTHERMAL & $2 / 1$ \\
\hline CRITICAL MINERALS & $3 / 2$ \\
\hline $\begin{array}{l}\text { OVERALL RATING } \\
\text { (WEIGHTED) }\end{array}$ & $2^{-}$ \\
\hline
\end{tabular}

NAMES OF CRITICAL MINERALS PRESENT: Possible copper; possible iron, zinc, cadmium, lead, fluorite, and barite at depth

COMMENTARY AND SUMMARY: This tract is in the fold-dominated Valley and Ridge. The rocks are quite favorable for oil and gas, al though some hydrocarbons may have been driven off by heat from metamorphism and igneous activity in the nearby Blue Ridge, heat that also made gas more common than oil throughout the province. These hydrocarbons are produced in several places in the province in the study area. Sandstone units may be favorable for uranium. The rocks are too old to contain coal. Hot dry rock at depth may have some potential for geothermal energy. Upper Devonian red beds may contain the critical mineral copper. Criticial minerals for which the subsurface rocks may be favorable include zinc and lead (Devonian Oriskany Sandstone); iron (Devonian Helderberg Limestone and Silurlan Clinton Formation); and zinc, cadmium, lead, fluorite, and barite (Ordovician carbonates). In the vicinity of the tract, little exploration has occurred except for oil and gas, for which exploration has been moderate.

GEOLOGY: Surface rocks are Upper Devonian shales and sandstones on the northwest flank of an anticline.

REFERENCE/CITATION: All resources - Milici and Others, 1963, Geol. Map of Va.; Gooch and Pharr, 1959, Mineral Indus. and Res. of Va.; USGS and USBM, 1968, USGS Prof. Paper 580; Miller and 0thers, 1970, Mineral Res. of the TVA Region; Brobst and Pratt, 1973, USGS Prof. Paper 820; D0E, 1978, Energy Res. Assessments of RARE II Lands; DOE, 1978, Energy Res. Assessments of Ten Alternatives - RARE II Lands; USFS, 1978, RARE II DES, So. Appal. Suppl. Oil and Gas - Vlissides and Quirin, 1963, 0il and Gas Fields of the U.S.; Cardwel1, 1971, AAPG Mem. 15; USGS, 1974 and 1975, Maps of Appal. 0il and Gas Production; Miller and Others, 1975, USGS Circ. 725; Harris and Milici, 1977, USGS Prof. Paper 1018; Patchen and 0thers, 1978, AAPG Bul1. 8. Uranium - ERDA, 1976, NURE Preliminary Report. Coal Trumbu11, 1960, Coal Fields of the U.S. Geothermal - AAPG, 1976a and b, Geothermal Gradient Map and Subsurf. Temp. Map of N. Am. Critical Minerals-Lesure, 1957, V.P.I. Bul1., Eng. Expt. Sta. series 118; Worl and Others, 1968, Fluorite Deposits of the U.S.; Lesure and Others, 1978, U.S.G.S. Bull. $1397 \mathrm{c}$. 
ENERGY AND MINERAL RESOURCE EVALUATION - RARE II TRACTS

TRACT NO: 08046

TRACT NAME: Little River

ECOREG : 2214

WAR: 20

NATIONAL FOREST: George Washington

STATE/COUNTY: Virginia, Augusta

ACREAGE (GROSS): 10,816 ACREAGE (NET): $10,816100 \mathrm{~N} / \mathrm{G}: 100$ LATITUDE: $38^{\circ} 25^{\prime}$ LONGITUDE: $79^{\circ} 13^{\prime}$

INDIVIDUAL TRACT

RESOURCE RATINGS

$\underline{O R N L} \quad \underline{U S F S} \quad \underline{D O E} \quad \underline{U S G S}$

REMARKS

$\begin{array}{lcc}\text { OIL AND GAS } & 3 / 2 & 1 \\ \text { URANIUM } & 2 / 1 & 1 \\ \text { COAL } & 1 / 4 & 1 \\ \text { GEOTIIERMAL } & 2 / 1 & 1 \\ \begin{array}{l}\text { CRITICAL MINERALS } \\ \text { OVERALL RATING } \\ \quad \text { WEIGHTED) }\end{array} & 3 / 2 & 1 \\ & & \\ \end{array}$

Possibly/mineral-bearing rocks are at shal low depth

(WEIGHTED)

NAMES OF CRITICAL MINERALS PRESENT: 'Possible copper; possible zinc, lead, iron, cadmium, fluorite, and barite at depth

COMMENTARY AND SUMMARY: This tract is in the fold-dominated Valley and Ridge. The rocks are quite favorable for oil and gas, although some hydrocarbons may have been driven off by heat from metamorphism and igneous activity in the nearby Blue Ridge, heat that also made gas more common than oil throughout the province. These hydrocarbons are produced in several places in the province in the study area. Sandstone units may be favorable for uranium. The rocks are too old to contain coal. Hot dry rock at depth may have some potential for geothermal energy. Upper Devonian red beds may contain the critical mineral copper. Criticial minerals for which the subsurface rocks may be favorable include zinc and lead (Devonian Oriskany Sandstone); iron (Devonian Helderberg Limestone and Silurian Clinton Formation); and zinc, cadmium, lead, fluorite, and barite (Ordovician carbonates). In the vicinity of the tract, little exploration has occurred except for oil and gas, for which exploration has been moderate.

GEOLOGY: Surface rocks are Upper Devonian shales and sandstones, synclinally tolded. Iract cut by Triassic (?) dike.

REFERENCE/CITATION: All resources - Milici and Others, 1963, Geol. Map of Va.; Gooch and Pharr, 1959, Mineral Indus. and Res. of Va.; USGS and USBM, 1968, USGS Prof. Paper 580; Miller and 0thers, 1970, Mineral Res. of the TVA Reqion; Brobst and Pratt, 1973, USGS Prof. Paper 820; D0E, 1978, Eneray Res. Assessments of RARE II Lands; DOE, 1978, Energy Res. Assessments of Ten Aiternatives - RARE II Lands; USFS, 1978, RARE II DES, So. Appal. Suppl. 0il and Gas - Vlissides and Quirin, 1963, 0il and Gas Fields of the U.S.; Cardwe11, 1971, AAPG Mem. 15; USGS, 1974 and 1975, Maps of Appal. 0il and Gas Production; Miller and Others, 1975, USGS Circ. 725; Harris and Milici, 1977, USGS Prof. Paper 1018; Patchen and Others, 1978, AAPG Bul1. 8. Uranium - ERDA, 1976, NURE Preliminary Report. Coal Trumbul1, 1960, Coal Fields of the U.S. Geothermal - AAPG, 1976a and b, Geothermal Gradient Map and Subsurf. remp. Map of N. Am. Critical Minerals-Lesure, 1957, V.P.I. Bull., Eng. Expt. Sta. series 118; Worl and Others, 1968, Fluorite Deposits of the U.S.; Lesure and 0thers, 1978, U.S.G.S. Bull. $1397 \mathrm{c}$. 
ENERGY AND MINERAL RESOURCE EVALUATION - RARE II TRACTS

TRACT N0: 08047

TRACT NAME: Big Schloss

ECOREG : 2214

WAR: 16

NATIONAL FOREST: George Washington

STATE/COUNTY: Virginia, Shenandoah/Frederick

ACREAGE (GROSS): 20,817 ACREAGE (NET): 20,478 $100 \mathrm{~N} / \mathrm{G}: 98.4$ LATITUDE: $39^{\circ} 00^{\prime}$ LONGITUDE: $78^{\circ} 35^{\prime}$

INDIVIDUAL TRACT

RESOURCE RATINGS $\underline{\text { ORNL }}$ USFS DOE USGS

REMARKS

OIL AND GAS

$3 / 1 \quad 1$

(0 $15 \mathrm{mi}$. east of an oil and gas field

(Patchen and 0thers 1978)

URANIUM

$2 / 1$

1

COAL

$1 / 4 \quad 1$

GEOTHERMAL

2,1

CRITICAL MINERALS $2 / 1 \quad 1$

Track lies within Timberlake Fluorite District (Worl and others 1974)

OVERALL RATING

(WEIGHTED)

$1^{+}$

NAMES OF CRITICAL MINERALS PRESENT: Possible iron; possible zinc, cadmium, lead, barite, and fluorite at depth

COMMENTARY AND SUMMARY: This tract is in the fold-dominated part of the Valley and Ridge province. The rocks are quite favorable for 011 and gas, al though some hydrocarbons may have been driven off by heat from metamorphism and igneous activity in the nearby Blue Ridge, heat that also made gas more common than oil throughout the province. These hydrocarbons are produced in several places in the province in the study area. Sandstone units may be favorable for uranium. The rocks are too old to contain coal. Hot dry rock at depth may have some potential for geothermal energy. The Silurian Clinton Formation at the surface may contain iron. Critical minerals for which the subsurface rocks may be favorable include zinc, cadmium, lead, barite, and fluorite (Ordovician carbonates). Fluorite has been produced in the region (Worl and 0thers 1974). In the vicinity of the tract, little exploration has occurred for any commodities except for $0 i l$ and gas, for which exploration has been only muderale.

GEOLOGY: Surface rocks are Ordovician and Silurian shales and sandstones anticlinally folded.

REFERENCE/CITATION: All resources - Milici and Others, 1963, Geol. Map of Va.; Gooch and Pharr, 1959, Mineral Indus, and Res. of Va.; USGS and USEM, 1968, USGS Prof. Paper 580; Milier and 0thers, 1970, Mineral Res. of the TVA Region; Brobst and Pratt, 1973, USGS Prof. Paper 820; D0E, 1978, Energy Res. Assessments of RARE II Lands; DOE, 1978, Energy Res. Assessments of Ten Alternatives - RARE II Lands; USFS, 1978, RARE II DES, So. Appa1. Suppl. 0il and Gas - Vlissides and Quirin, 1963, 0il and Gas Fields of the U.S.; Cardwe11, 1971, AAPG Mem. 15; USGS, 1974 and 1975, Maps of Appal. Oil and Gas Production; Miller and Others, 1975, USGS Circ. 725; Harris and Milici, 1977, USGS Prof. Paper 1018; Patchen and Others, 1978, AAPG Bu11. 8. Uranium - ERDA, 1976, NURE Preliminary Report. Coal Trumbul 1, 1960, Coal Fieids of the U.S. Geothermal - AAPG, 1976a and b, Geothermal Gradient Map and Subsurf. Temp. Map of N. Am. Critical Minerals-Lesure, 1957, V.P.I. Bul1., Eng. Expt. Sta. series 118; Worl and 0thers, 1968, Fluorite Deposits of the U.S.; Lesure and 0thers, 1978, U.S.G.S. Bul1. $1397 \mathrm{c}$. 
ENERGY AND MINERAL RESOURCE EVALUATION - RARE II TRACTS

TRACT NO: 08048

TRACT NAME: Beartown

ECOREG: 2214

WAR: 22

NATIONAL FOREST: Jefferson

ACREAGE (GROSS): 10,542 ACREAGE (NET): 7,469

STATE/COUNTY: Virginia, Tazewe11/B]and

INDIVIDUAL TRACT

RESOURCE RATINGS

\begin{tabular}{|c|c|c|}
\hline ORNL & USFS & $\underline{D O E}$ \\
\hline $3 / 2$ & 1 & \\
\hline $2 / 1$ & 1 & 2 \\
\hline $1 / 4$ & 1 & 3 \\
\hline $2 / 1$ & 1 & \\
\hline $3 / 1$ & 1 & \\
\hline $2^{+}$ & & 3 \\
\hline
\end{tabular}

$100 \mathrm{~N} / \mathrm{G}: 70.8$ LATITUDE: $37^{\circ} 03^{\prime}$ LONGITUDE: $81^{\circ} 27^{\prime}$

OIL AND GAS

URANIUM

COAL

GEOTHERMAL.

CRITICAL MINERALS

OVERALL RATING

(WEIGHTED)

NAMES OF CRITICAL MINERALS PRESENT: Possible iron, manganese, zinc, and lead; possible zinc, lead, cadmium, barite, and fluorite at depth

COMMENTARY AND SUMMARY: This tract is in the thrust fault-dominated part of the Valley and Ridge province. The rocks are quite favorable for 011 and gas. Sandstone units may be favorable for uranium. The rocks are too old for coal. Hot dry rock at depth may be favorable as a source of geothermal energy. Critical minerals for which the surface rocks are favorable include zinc, manganese, and lead (weathered Devonian Oriskany Sandstone) and iron (Devonian Helderberg Limestone and Silurian Clinton Formation). Ordovician carbonates at depth may contain zinc, lead, cadmium, barite, and fluorite. Except for oil and gas, littie exploration has takeh place for resources in the immediate ared.

GEOLOGY: Surface rocks are Upper Ordovician to Lower Devonian shales and sandstones anticlinally folded.

REFERENCE/CITATION: Al1 resources - Milici and Others, 1963, Geol. Map of Va.; Gooch and Pharr, 1959, Mineral Indus. and Res. of Va.; USGS and USBM, 1968, USGS Prof. Paper 580; Miller and 0thers, 1970, Mineral Kes. of the TVA Region; Brobst and Pratt, 1973, USGS Prof. Paper 820; D0E, 1978, Energy Res. Assessments of RARE II Lands; DOE, 1978, Energy Res. Assessments of Ten A1ternatives - RARE II Lands; USFS, 1978, RARE II DES, So. Appal. Suppl. Oi1 and Gas - V1 issides and Quirin, 1963, 0il and Gas Fields of the U.S.; Cardwel1, 1971, AAPG Mem. 15; USGS, 1974 and 1975, Maps of Appal. 0il and Gas Production: Miller and Others, 1975, USGS Circ. 125; Harris and Milici, 1977, USGS Prof. Paper 1018; Patchen and Others, 1978, AAPG Bu11. 8. Uranium - ERDA, 1976, NURE Prel iminary Report. Coal Trumbu11, 1960, Coal Fields of the U.S. Geothermal - AAPG, 1976a and b, Geothermal Gradient Map and Subsurf. Temp. Map of N. Am. Critical Minerals-Lesure, 1957, V.P.I. Bu11., Eng. Expt. Sta. series 118; Worl and Others, 1968, Fluorite Deposits of the U.S.; Lesure and 0thers, 1978, U.S.G.S. Bul1. $1397 \mathrm{c}$. 
ENERGY AND MINERAL RESOURCE EVALUATION - RARE II TRACTS

TRACT NO: 08049

TRACT NAME: Little Dry Run

ECOREG: 2214

WAR: 21

NATIONAL FOREST: Jefferson

STATE/COUNTY: Virginia, Wythe

ACREAGE (GROSS): 2,998 ACREAGE (NET): $2,998 \quad 100 \mathrm{~N} / \mathrm{G}: 100 \quad$ LATITUDE: $36^{\circ} 47^{\prime} \quad$ LONGITUDE: $81^{\circ} 13^{\prime}$

INDIVIDUAL TRACT

RESOURCE RATINGS

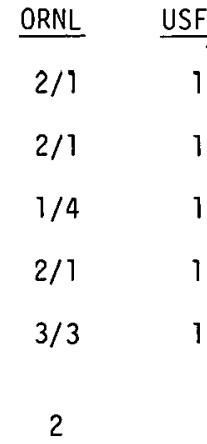

$\underline{\text { DOE }} \quad \underline{\text { USGS }}$

REMARKS

OIL AND GAS

1

URANIUM

1

COAL

1

GEOTHERMAL

1

CRITICAL MINERALS

1

Shady dolomite at surface

OVERALL RATING

(WEIGHTED)

NAMES OF CRITICAL MINERALS PRESENT: Possible manganese and iron

COMMENTARY AND SUMMARY: This tract is in the thrust fault-dominated part of the Valley and Ridge province. The rocks may be favorable for gas in thrust sheets at depth below the Cambrian rocks (Harris 1976). Sandstones and conglomerates may be favorable for uranium. The rocks are too old for coal. Hot dry rock at depth may be favorable as a source of geothermal energy. Manganese and iron deposits: are likely to be found in the weathered Shady Dolomite (King and Ferguson 1960). Except for manganese and iron, for which there has been moderate exploration, little exploration has occurred in the immediate area for resources.

GEOLOGY: Partly metamorphosed Cambrian Chilhowee Group, the Cambrian Shady Dolomite, and the Cambrian Rome Shale synclinally folded and thrust faulted.

REFERENCE/CITATION: All resources - Milici and Others, 1963, Geol. Map of Va.; Gooch and Pharr, 1959, Mineral Indus. and Res. of Va.; USGS and USBM, 1968, USGS Prof. Paper 580; Miller and 0thers, 1970, Mineral Res. of the TVA Region; Brobst and Pratt, 1973, USGS Prof. Paper 820; D0E, 1978, Energy Res. Assessments of RARE II Lands; DOE, 1978, Energy Res. Assessments of Ten Alternatives - RARE II Lands; USFS, 1978, RARE II DES, So. Appa1. Suppl. Oil and GaS - VI issides and Quirin, 1963, 0il and Gas Fields of the U.S.; Cardwel1, 1971, AAPG Mem. 15; USGS, 1974 and 1975, Maps of Appal. 0i1 and Gas Production; Miller and Others, 1975, USGS Circ. 725; Harris and Milic1, 1977, USGS Pruf. Paper 1018; Patchen and 0thers, 1978, AAPG Bu11. 8. Uranium - ERDA, 1976, NURE Prel iminary Report. Coal Trumbul1, 1960, Coal Fields of the U.S. Geothermal - AAPG, 1976a and b, Geothermal Gradient Map and Subsurf. Temp. Map of N. Am. Critical Minerals-Lesure, 1957, V.P.I. Bul1., Eng. Expt. Sta. series 118; Worl and Others, 1968, Fluorite Deposits of the U.S.; Lesure and 0thers, 1978, U.S.G.S. Bu11. $1397 \mathrm{c}$. 
ENERGY AND MINERAL RESOURCE EVALUATION - RARE II TRACTS

TRACT N0: 08050

NATIONAL FOREST: Jefferson

ACREAGE (GROSS): 5,771
TRACT NAME: Lewis Fork

ECOREG : 2210

WAR: 20

ACREAGE (NET): 5,749 $100 \mathrm{~N} / \mathrm{G}: 100$ LATITUDE: $36^{\circ} 40^{\prime}$ LONGITUDE: $81^{\circ} 33^{\prime}$

INDIVIDUAL TRACT

RESOURCE RATINGS

$\underline{\text { ORNL }} \underline{\text { USFS }} \underline{\text { DOE }} \underline{\text { USGS }}$

REMARKS

OIL AND GAS

$2 / 1$

URANIUM

$? / ?$

COAL

GEOTHERMAL

$2 / 1$

r.RTTTR.AL MINFRAIS . $3 / 1$

Volcanic rocks favorable

OVERALL RATING

(WEIGHTED)

NAMES OF CRITICAL MINERALS PRESENT: Possible igneous or vein deposits of mica, feldspar, and rare earths

COMMENTARY AND SUMMARY: This tract is in the Blue Ridge province. The rocks may be favorable for gas at depth below the basal Blue Ridge Thrust (Harris 1976). The rocks are favorable for uranium but are too old for coal. Hot dry rock. at depth may be favorable as a source of geothermal. energy. No critical minerals are known to occur in the tract, but igneous or hydrothermal veins may be favorable for mica, feldspar, and rare earths. Little exploration has occurred for resources in the immediate area.

GEOLOGY: Surface rocks are the Precambrian-Cambrian Mt. Rogers Volcanic Group

REFERENCE/CITATION: All resources - Milici and Others, 1963, Geol. Map of Va.; Gooch and Pharr, 1959, Mineral Indus. and Res. of Va.; USGS and USBM, 1968, USGS Prof. Paper 580; Miller and 0thers, 1970, Mineral Res. of the TVA Region; Brobst and Pratt, 1973, USGS Prof. Paper 820; D0E, 1978, Energy Res. Assessments of RARE II Lands; DOE, 1978, Energy Res. Assessments of Ten Alternatives - RARE II Lands; USFS, 1978, RARE II DES, So. Appal. Suppl. U1I and Gas - V11ss1des and Quir1n, 1963, 011 dild Gds Fields of the U.S.; Cardwel1, 1971, AAPG Mem. 15; USGS, 1974 and 1975, Maps of Appal. 0i1 and Gas Production; Miller and Others, 1975, USGS Circ. 725; Harris and Milici, 1977, USGS Prof. Paper 1018; Patchen and Others, 1978, AAPG Bu11.8. Uranium - tKUA, 19/6, NURE Prel iminary Report. Cual Trumbu11, 1960, Coal Fieids of the U.S. Geothermal - AAPG, 1976a and b, Geothermal Gradient Map and Subsurf. Temp. Map of N. Am. Critical Minerals-Lesure, 1957, V.P.I. Bul1., Eng. Expt. Sta. series 118; Worl and Others, 1968, Fluorite Deposits of the U.S.; Lesure and Others, 1978, U.S.G.S. Bull. $1397 \mathrm{c}$. 
ENERGY AND MINERAL RESOURCE EVALUATION - RARE II TRACTS

TRACT NO: 08051

NATIONAL FOREST: Jefferson
TRACT NAME: Roaring Branch

ECOREG: 2211

WAR: 21

STATE/COUNTY: Virginia, Lee/Wise

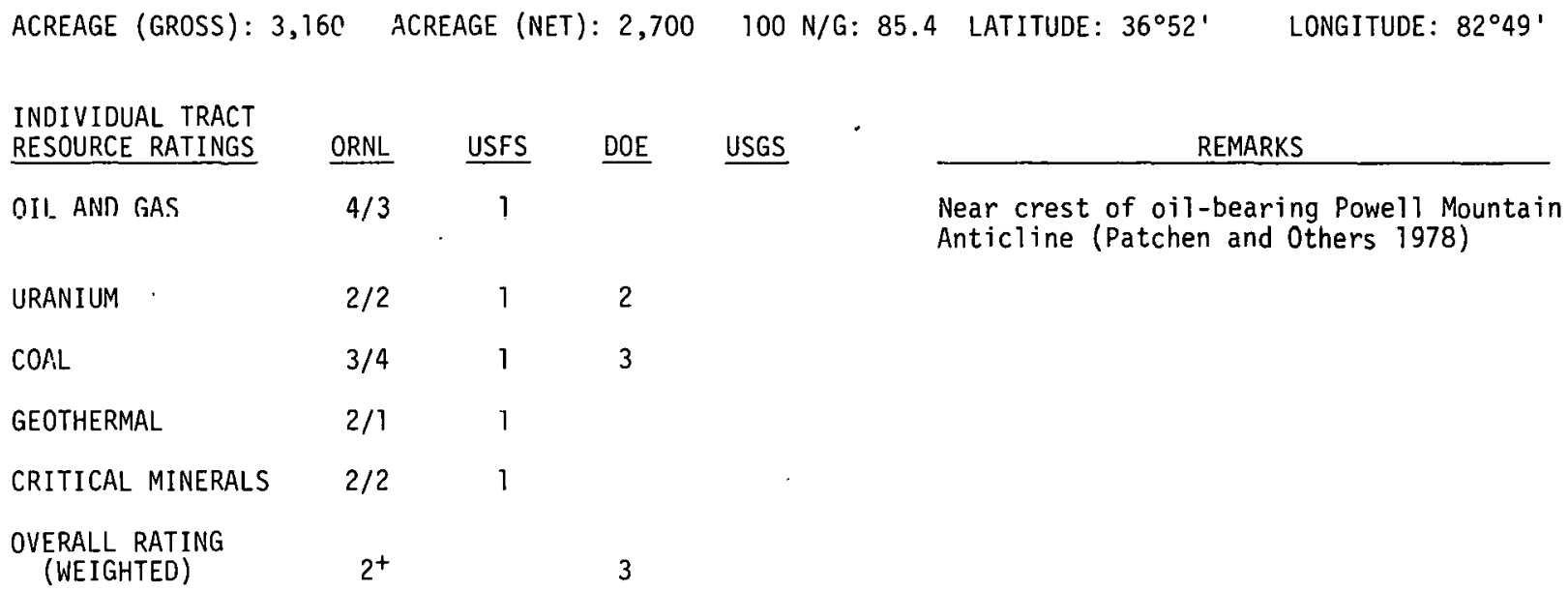

NAMES OF CRITICAL MINERALS PRESENT: Possible copper, zinc, iron, cadmium, lead, fluorite, and barite at depth

COMMENTARY AND SUMMARY: This tract is in the thrust fault-dominated part of the Valley and Ridge province. The rocks are favorable for oil and gas, which are produced in this part of the province. Sandstone units may be favorable for uranium. The tract is on the edge of the Appalachian coal field. Coal underlies part of the tract but is thin and of low quality. Hot'dry rock at depth may be favorable as a source of geothermal energy. The surface rocks probably contain no critical minerals, but older rocks at depth may be favorable for copper (Upper Devonian red beds); zinc and lead (Devonian Oriskany Sandstone); iron (Devonian Helderberg Limestone and Silurian Clinton Formation); and zinc, cadmium, lead, fluorite, and barite (Ordovician carbonates). In the general area, little exploration for any commodities has occurred except for oil and gas, for which exploration has been considerable.

GEOLOGY: Surface rocks are Upper Mississippian and Pennsylvanian shales and sandstones on the northwest flank of an anticline in the upper plate of Pine Mountian Thrust.

REFERENCE/CITATION: All resources - Milici and Others, 1963, Geol. Map of Va.; Gooch and Pharr, 1959, Mineral Indus. and Res. of Va.; USGS and USBM, 1968, USGS Prof. Paper 580; Miller and 0thers, 1970, Mineral Res. of the TVA Region; Brobst and Pratt, 1973, USGS Prof. Paper 820; DOE, 1978, Energy Res. Assessments of RARE II Lands; DOE, 1978, Energy Res: Assessments of Ten Alternatives - RARE II Lands; USFS, 1978, RARE II DES, So. Appa1. Suppl. 0il and Gas - V1issides and Quirin, 1963, 0il and Gas Fields of the U.S.; Cardwell, 1971, AAPG Mem. 15; IISGS, 1974 and 1975, Maps of Appal. 0il and Gas Production; Miller and Others, 1975, USGS Circ. 725; Harris and Milici, 1977, USGS Prof. Paper 1018; Patchen and Others, 1978, AAPG Bu11. 8. Uranium - ERDA, 1976, NURE Preliminary Report. Coal Trumbul1, 1960, Coal Fields of the U.S. Geothermal - AAPG, 1976a and b, Geothermal Gradient Map and Subsurf. Temp. Map of N. Am. Critical Miñerals-Lesure, 1957, V.P.I. Bu11., Eng. Expt. Sta. series 118; Worl and 0thers, 1968, Fluorite Deposits of the U.S.; Lesure and Others, 1978, U.S.G.S. Bul1. $1397 \mathrm{c}$. 
ENERGY AND MINERAL RESOURCE EVALUATION - RARE II TRACTS

TRACT N0: 08052

NATIONAL FOREST: Jefferson

ACREAGE (GROSS): 1,050
TRACT NAME: Little Stoney

ECOREG: 2214 WAR: 16
INDIVIDUAL TRACT

RESOURCE RATINGS

OIL AND GAS

URANIUM

COAL

GEOTHERMAL

CRITICAL MINERALS

OVERALL RATING

(WEIGHTED) $\underline{\text { ORNL }} \underline{\text { USFS }}$ DOE $\underline{\text { USGS }}$

$4 / 2 \quad 1$

$2 / 2$

$3 / 4$

$2 / 1$

$2 / 1$

$2^{+}$
STATE/COUNTY: Virginia, Scott/Wise

$100 \mathrm{~N} / \mathrm{G}: 100$ LATITUDE: $36^{\circ} 52^{\prime} \quad$ LONGITUDE: $82^{\circ} 27^{\prime}$

NAMES OF.CRITICAL MINERALS PRESENT: Possible copper, zinc, iron, cadmium, lead, fluorite, and barite at depth

COMMENTARY AND SUMMARY: This tract is in the thrust fault-dominated part of the Valley and Ridge province. The rocks are favorable for oil and gas, which are produced in this part of the province. Sandstone units may be favorable for uranium. The tract is on the edge of the Appalachian coal field. Coal underlies part of the tract but is thin and of low quality. Hot dry rock at depth may be favorable as a source of geothermal energy. The surface rocks probably curitain no critical minerals, but older rocks at depth may be favorable for copper (Upper Devonian red beds); zinc and lead (Devonian Oriskany Sandstone); iron (Devonian Helderberg Limestone and Silurian Clinton Formation); and zinc, cadmium, lead, fluorite, and barite (Ordovician carbonates). In the general area, little exploration for any commodities has occurred except for oil and gas, for which exploration has been considerable.

GEOLOGY: Surface rocks are Lower Pennsylvanian shales and sandstones, synclinally folded, in the upper plate of the Pine Mountain overthrust.

REFERENCE/CITATION: A11 resources - Milici and 0thers, 1963, Geol. Map of Va.; Gooch and Pharr, 1959, Mineral Indus. and ReS. Of Va.; USGS and USBM, 1968, USGS Prof. Paper 580; Miller and 0thers, 1970, Mineral Res. of the TVA Region; Brobst and Pratt, 1973, USGS Prof. Paper 820; D0E, 1978, Energy Res. Assessments of RARE II Lands; DOE, 1978, Energy Res. Assessments of Ten Alternatives - RARE II Lands; USFS, 1978, RARE II DES, So. Appa1. Suppi. Oil and Gas - Vlissides and Uuirin, 1963, 011 and Gas Fields of the U.S.; Cardwel1, 1971, AAPG Mem. 15; USGS, 1974 and 1975, Maps of Appal. 0il and Gas Production; Miller and 0thers, 1975, USGS Circ. 725; Harris and Milici, 1977, USGS Prof. Paper 1018; Patchen and Others, 1978, AAPG Bu11. 8. Uranium - ERDA, 1976, NURE Preliminary Report. Coal Trumbul1, 1960, Coal Fields of the U.S. Geothermal - AAPG, 1976a and b, Geothermal Gradient Map and Subsurf. Temp. Map of N. Am. Critical Minerals-Lesure; 1957, V.P.I. Bul1., Eng. Expt. Sta. series 118; Worl and Others, 1968, Fluorite Deposits of the U.S.; Lesure and Others, 1978, U.S.G.S. Bul1. $1397 \mathrm{c}$. 
ENERGY AND MINERAL RESOURCE EVALUATION - RARE II TRACTS

TRACT NO: 08053

TRACT NAME: Little Wilson Creek

ECOREG : 2214

WAR: 22

NATIONAL FOREST: Jefferson

STATE/COUNTY: Virginia, Grayson

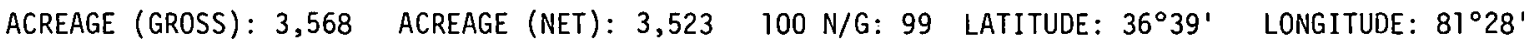

INDIVIDUAL TRACT

RESOURCE RATINGS

$\underline{\text { ORNL }} \underline{\text { USFS }} \underline{\text { DOE }} \underline{\text { USGS }}$

REMARKS

OIL AND GAS

$2 / 1 \quad 1$

URANIUM

$2 / 2 \quad 1$

COAL

$1 / 4 \quad 1$

GEOTHERMAL

$2 / 1$

1

CRITICAL MINERALS

$2 / 1$

1

OVERALL RATING

(WEIGHTED)

$1^{+}$

NAMES OF CRITICAL MINERALS PRESENT: Possible igneous or vein deposits of mica, feldspar, and rare earths

COMMENTARY AND SUMMARY: This tract is in the Blue Ridge province. The rocks may be favorable for gas at depth below the basal Blue Ridge Thrust (Harris 1976). The rocks are favorable for uranium but are too old for coal. Hot dry rock at depth may be favorable as a source of geothermal energy. No critical minerals are known to occur in the tract, but igneous or hydrothermal veins may be favorable for mica, feldspar, and rare earths. Little exploration has occurred for resources in the immediate area.

GEOLOGY: Surface rocks are the Precambrian Mt. Rogers Volcanic Group.

REFERENCE/CITATION: All resources - Mịlịi and nthers, 1963, Geol. Map of Va,; Gooch and Pharr, 1959, Mineral Indus. and ReS. of Va.; USGS and USBM, 1968, USGS Prof. Paper 580; Miller. and 0thers, 1970, Mineral Res. of the TVA Region; Brobst and Pratt, 1973, USGS Prof. Paper 820; D0E, 1978, Energy Res. Assessments of RARE II Lands; DOE, 1978, Energy Res. Assessments of Ten Alternatives - RARE II Lands; USFS, 1978, RARE II DES, So. Appa1. Suppl. 0 il and Gas - Vlissides and Quirin, 1963, 0il and Gas Fields of the U.S.; Cardwel1, 1971; AAPG Mem. 15; USGS, 1974 and 1975, Maps of Appal. 0il and Gas Production; Miller and Others, 1975, USGS Circ. 725; Harris and Milici, 1977, USGS Prof. Paper 1018; Patchen and Others, 1978, AAPG Bul1. 8. Uranium - ERDA, 1976, NURE Prelininary Report. Coal Trumbul1, 1960, Coal Fields of the U.S. Geothermal - AAPG, 1976a and b, Geothermal Gradient Map and Subsurf. Temp. Map of N. Am. Critical Minerals-Lesure, 1957, V.P.I. Bull., Eng. Expt. Sta. Series 118; Worl and Others, 1968, Fluorite Deposits of the U.S.; Lesure and Others, 1978, U.S.G.S. Bull. $1397 \mathrm{c}$. 
ENERGY AND MINERAL RESOURCE EVALUATION - RARE II TRACTS

TRACT NO: 08054

NATIONAL FOREST: Pisgah

ACREAGE (GROSS): 5,500
TRACT NAME: Big Creek

STATE/COUNTY: North Carolina, Madison

$100 \mathrm{~N} / \mathrm{G}: 76$ LATITUDE: $36^{\circ} 05^{\prime}$ LONGITUDE: $82^{\circ} 40^{\prime}$

INDIVIDUAL TRACT

RESOURCE RATINGS $\underline{\text { ORNL }}$ USFS $\underline{\text { DOE }} \underline{\text { USGS }}$

OIL AND GAS

$2 / 1 \quad 1$

URANIUM

$2 / 2$

COAL

$1 / 4$

1

2

Within NURE f'avorable area (tKUA $(y / 6$ )

GEOTHERMAL

$2 / 1$

1

1

CRITICAL MINERALS

$3 / 1$

1

OVERALL RATING

(WEIGHTED)

$2^{-}$

2

NAMES OF CRITICAL MINERALS PRESENT: POSSible iron, barite, and manganese

COMMENTARY AND SUMMARY: This tract is in the Hot Springs Window of the Blue Ridge province. The rocks below the basal Blue Ridge Thrust may be favorable for gas (Harris 1976). The tract is within an area classified as favorable for uranium by NURE (ERDA 1976). The rocks are too old for coal. Hot dry rock at depth may be favorable as a source of geothermal energy. The mineral environment is similar to that of the Hot Springs Barite District, N.C. (Oriel 1950), so that the rocks are favorable for barite, iron, and manganese. Little exploration has occurred for any resources in the immediate area.

GEOLOGY: Surface rocks are Upper Precambrian sediments and the Lower Cambrian Unicoi Formation.

REFERENCE/CITATION: All resources - N.C. Dept. Conserv. and Develop., Div. Min. Res., 1959, Geol. Map of N.C.; USGS and USBM, 1968, USGGS Prof. Paper 580; Milier and Others, 1970, Mineral Res. of the TVA Region; Bryant and Reed, 1970, USGS Prof. Paper 615; Brobst and Pratt, 1973, USGS Prof. Paper 820; DOE, 1978, Energy Res. Assessments of RARE II Lands; DOE, 1978, Energy Res. Assessments of Ten A1ternatives - RARE II Lands; USFS, 1978, RARE II DES, So. Appal. Supp 1. 0il and Gas - Vlissides and Quirin, 1963, 0il and Gas Fields of the U.S.; Cardwe11, 1971, AAPG Mem. 15; USGS, 1974 and 1975, Maps of Appa1. 0i and Gas Production; Miller and Others, 1975, USGS Circ. 725; Harris and Milici, 1977, USGS Prof. Paper 1018; Patchen and Others, 1978, AAPG Bu11. 8. Uranium - Bryant and Reed, 1966, USGS Circ. 521; ERDA, 1976, NURE Prel iminary Report. Coal - Trumbul1, 1960, Coal Fields of the U.S. Geothermal - AAPG, 1976a and b, Geothermal Gradient Map and Subsurface Temperature Map of North America. Critical Minerals - Lesure, 1968, USGS Prof. Paper 577; Orie1, 1950, N.C. Dept. Conserv. and Devel., Div. Min. Res., Bul1. 60. 
ENERGY AND MINERAL RESOURCE EVALUATION - RARE II TRACTS

TRACT NO: 08055

TRACT NAME: Balsam Cone

ECOREG: 2214

WAR: 19

NATIONAL FOREST: Pisgah

STATE/COUNTY: North Carolina, Yancy

ACREAGE (GROSS): 14,429 ACREAGE (NET): $13,529100 \mathrm{~N} / \mathrm{G}: 93.7$ LATITUDE: $35^{\circ} 52^{\prime} \quad$ LONGITUDE: $82^{\circ} 15^{\prime}$

INDIVIDUAL TRACT

RESOURCE RATINGS

$\underline{\text { ORNL USFS DOE USGS }}$

REMARKS

OIL AND GAS

$2 / 1$

1

URANIUM

$2 / 2$

NURE favorable area

(ERDA 1976)

COAL

$1 / 4 \quad 1$

GEOTHERMAL

$2 / 1 \quad 1$

CRITICAL MINERALS

$4 / 3 \quad 1$

Spruce Pine Mica District (Lesure 1968)

OVERALL RATING

(WEIGHTED)

$3^{+}$

NAMES OF CRITICAL MINERALS PRESENT: Probable mica; possible nickel, chromium, and asbestos

COMMENTARY.AND SUMMARY: This tract is in the Blue Ridge province. Sedimentary rocks below the basal Blue Ridge Thrust may be favorable for gas (Harris 1976). Pegmatite veins are favorable for uranium (ERDA 1976). The rocks are too old for coal. Hot dry rock at depth may be favorable as a source of geothermal energy. The tract is in the Spruce Pine Mica District (Lesure 1968). Pegmatite veins and mica schists are quite favorable for mica. Considerable exploration and production have taken place in the area. UTtramafic rocks may contain nickel and chromium. Except for critical minerals, little exploration has occurred for resources in the immediate area.

GEOLOGY: Surface rocks are Upper Precambrian Great Smoky Group, chiefly mica and hornblende gneiss and schist, possibly some ultramafics.

REFERENCE/CITATION: Al1 resources - N.C. Dept. Conserv. and Develop., Div. Min. Res.; 1959, Geol. Map of N.C.; USGS and USBM, 1968, USGS Prof. Paper 580; Miller and 0thers, 1970, Mineral Res. of the TVA Region; Bryant and Reed, 1970, USGS Prof. Paper 615; Brobst and Pratt, 1973, USGS Prof. Paper 820; DOE, 1978, Energy Res. Assessments of RARE II Lands; DOE, 1978, Energy Res. Assessments of Ten Alternatives - RARE II Lands; USFS, 1978, RARE II DES, So. Appal. Suppl. 0il and Gas - Vlissides and Quirin, 1963, 011 and Gas Fields of the U.S.; Cardweil, 1971, AAPG Mem. 15; USGS, 1974 and 1975, Maps of Appal. 0 il and Gas Production; Miller and Others, 1975, USGS Circ. 725; Harris and Milici, 1977, USGS Prof. Paper 1018; Patchen and Others, 1978, AAPG Bul1. 8. Uranium - Bryant and Reed, 1966, USGS Circ. 521; ERDA, 1976, NURE Preliminary Report. Coal - Trumbu11, 1960, Coal Fields of the U.S. Geothermal - AAPG, 1976a and b, Geothermal Gradient Map and Subsurface Temperature Map of North America. Critical Minerals - Lesure, 1968, USGS Prof. Paper 577; Oriel, 1950, N.C. Dept. Conserv. and Devel., Uiv. Min. Res., Bul1. 60. 
ENERGY AND MINERAL RESOURCE EVALUATION - RARE II TRACTS

TRACT NO: 08056

NATIONAL FOREST: Pisgah

ACREAGE (GROSS): 1,280
TRACT NAME: Craggy Mountain Extension

ECOREG: 2214

WAR: 22

STATE/COUNTY: North Carolina, Buncombe

ACREAGE (NET): $1,195 \quad 100 \mathrm{~N} / \mathrm{G}: 93.3$ LATITUDE: $35^{\circ} 43^{\prime}$

LONGITUDE: $82^{\circ} 23^{\prime}$
INDIVIDUAL TRACT

RESOURCE RATINGS

OIL AND GAS

URANIUM

COAL

GEOTHERMAL

C.RITITAL MINERALS

OVERALL RATING

(WEIGHTED)

$\begin{array}{cccc}\begin{array}{ccc}\text { ORNL } \\ 2 / 1\end{array} & \text { USFS } & \text { DOE } & \text { USGS } \\ 2 / 2 & 1 & \\ 1 / 4 & 1 & \\ 2 / 1 & 1 & \\ 3 / 1 & 1 & \\ 2^{+} & & \end{array}$

REMARKS

NAMES OF CRITICAL MINERALS PRESENT: Possible mica

COMMENTARY AND SUMMARY: This tract is in the Blue Ridqe province. Sedimentary rocks helnw the hasal Blue Ridge Thrust may be favorable for gas (Harris 1976). The tract is in a NURE favorable area (ERDA 1976). Pegmatite veins may contain uranium. The rocks are too old for coal. Hot dry rock at depth may be favorable as a source of geothermal energy. The gneisses and schists probably contain mica; the tract is in the Buncombe Mica District (Lesure 1968), and some exploration has occurred. Except for critical minerals, little exploration has taken place for resources in the immediate area.

GEOLOGY: Upper Precambrian Great Smoky Group, mainly mica and hornblende gneiss and schist.

REFERENCE/CITATION: Al1 resources - N.C. Dept. Conserv. and Develop., Div. Min. Res., 1959, Geol. Map of N.C.; USGS and USBM, 1968, USGS Prof. Paper 580; Miller and Others, 1970, Mineral Res. of the TVA. Region; Bryant and Reed, 1970, USGS Prof. Paper 615; Brobst and Pratt, 1973, USGS Prof. Paper 820; DOE, 1978, Energy Res. Assessments of RARE II Lands; DOE, 1978, Energy Res. Assessments of Ten Alternatives - RARE II Lands; USFS, 1978, RARE II DES, So, Appal. Suppl. 0il and Gas - Vlissides and Quirin, 1963, 0il and Gas Fields of the U.S.; Cardwe11, 1971, AAPG Mem. 15; USGS, 1974 and 1975, Maps of Appal. Oil and Gas Production; Miller and Others, 1975, USGS Circ. 725; Harris and Milici, 1977, USGS Prof. Paper 1018; Patchen and 0thers, 1978, AAPG Bu11. 8. Uranium - Bryant and Reed, 1966, USGS Circ. 521; ERDA, 1976, NURE Preliminary Report. Coal - Trumbul1, 1960, Coal Fields of the U.S. Geothermal - AAPG, 1976a and b, Geothermal Gradient Map and Subsurface Temperature Map of North America. Critical Minerals - Lesure, 1968, USGS Prof. Paper 577; Oriel, 1950, N.C. Dept. Conserv. and Devel., Div. Min. Res., Bul1.60. 
ENERGY AND MINERAL RESOURCE EVALUATION - RARE II TRACTS

TRACT N0: 08057

NATIONAL FOREST: Pisgah

ACREAGE (GROSS): 10,400
TRACT NAME: Shining Rock Extension

ECOREG: 22

STATE/COUNTY: North Carolina, Haywood

ACREAGE (NET): 10,400

$100 \mathrm{~N} / \mathrm{G}: 100$ LATITUDE: $35^{\circ} 20^{\prime}$ LONGITUDE: $82^{\circ} 52^{\prime}$
WAR: 16
INDIVIDUAL TRACT
RESOURCE RATINGS

\section{OIL AND GAS}

URANIUM

COAL

GEOTHERMAL

CRITICAL MINERALS

OVERALL RATING

(WEIGHTED)

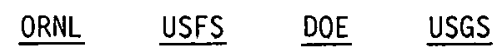

$2 / 1 \quad 1$

$3 / 2 \quad 1$

$1 / 4 \quad 1$

$2 / 1 \quad 1$

$4 / 3 \quad 1$

Franklin-Sylva Mica District (Lesure 1968)

NAMES OF CRITICAL MINERALS PRESENT: Mica, gold(?), and silver (?)

COMMENTARY AND SUMMARY: This tract is in the Blue Ridge province. It is actually three separate tracts, to all of which this assessment applies. The rocks below the basal Blue Ridge Thrust may be favorable for gas (Harris 1976). Pegmatites are favorable for uranium (ERDA 1976). The rocks are too old for coal. Hot dry rock at depth may be favorable as a source of geothermal energy. Prospects for mica, a critical mineral, occur within the larger lower tract, and all tracts are within the Franklin-Sylva Mica District (Lesure 1968). Except for critical minerals, little exploration has occurred for resources in the immediate area.

GEOLOGY: Surface rocks are chiefly gneiss and migmatite with abundant granite, all believed to be of Precambrian age.

REFERENCE/CITATION: AlI resources -- N.C. Dept. Conserv, and Develop., Div. Min. Res., 1959, Geol. Map of N.C.; USGS and USBM, T968, USGS Prof. Paper 580; Miller and Others, 1970, Mineral Res. Of the TVA Region; Bryant and Reed, 1970, USGS Prof. Paper 615; Brobst and Pratt, 1973, USGS Prof. Paper 820; DOE, 1978, Energy Res. Assessments of RARE II Lands; DOE, 1978, Energy Res. Assessments of Ten A1ternatives - RARE II Lands; USFS, 1978, RARE II DES, So. Appal. Supp1. 0il and Gas - VIissides and Quirin, 1963, 0i1 and Gas Fields of the U.S.; Cardwel1, 1971, AAPG Mem. 15; USGS, 1974 and 1975, Maps of Appal. Oil and Gas Production; Miller and Others, 1975, USGS Circ. 725; Harris and Milici, 1977, USGS Prof. Paper 1018; Patchen and Others, 1978, AAPG Bu11. 8. Uranium - Bryant and Reed, 1966, USGS Circ. 521; ERDA, 1976, NURE Preliminary Report. Coal - Trumbul1, T960, Coal Fields of the U.S. Geotlierill 1 - AAPG, $1976 \mathrm{a}$ and b, Geothermal Gradient Map and Subsurface Temperature Map of North America. Critical Minerals - Lesure, 1968, USGS Prof. Paper 577; Oriel, 1950, N.C. Dept. Conserv. and Devel., Div. Min. Res., Bull. 60 . 
ENERGY AND MINERAL RESOURCE EVALUATION - RARE II TRACTS

TRACT N0: 08058

NATIONAL FOREST: Pisgah

ACREAGE (GROSS): 3,503
TRACT NAME: Linville Gorge Extension

ECOREG : 2214

WAR: 12
STATE/COUNTY: North Carolina, Bürke

$100 \mathrm{~N} / \mathrm{G}: 88.5 \quad$ LATITUDE: $35^{\circ} 52^{\prime} \quad$ LONGITUDE: $81^{\circ} 52^{\prime}$

\begin{tabular}{|c|c|c|c|c|c|}
\hline $\begin{array}{l}\text { INDIVIDUAL TRACT } \\
\text { RESOURCE RATINGS } \\
\end{array}$ & $\underline{\text { ORNL }}$ & $\underline{\text { USFS }}$ & $\underline{D O E}$ & $\underline{\text { USGS }}$ & REMARKS \\
\hline OIL AND GAS & $2 / 1$ & 1 & & & \\
\hline URAÑIUM & $3 / 2$ & 1 & & & "Speculative" area (ERDA 1976) \\
\hline COAL & $1 / 4$ & 1 & & & \\
\hline GEOTHERMAL & $2 / 1$ & 1 & & & \\
\hline CRITICAL MINERALS & $3 / 2$ & 1 & & & . \\
\hline $\begin{array}{l}\text { OVERALL RATING } \\
\text { (WEIGHTED) }\end{array}$ & $2^{+}$ & & & & \\
\hline
\end{tabular}

NAMES OF CRITICAL MINERALS PRESENT: Possible zinc, manganese, iron, and lead

COMMENTARY AND SUMMARY: This tract is within the Grandfather Mountain Window of the Blue Ridge province. The rocks may be favorable for gas at depth below the basal Blue Ridge Thrust (Harris 1976), but if the Brevard Zone nearby to the southeast is the root zone of the west-directed thrusting (Bryant and Reed 1970), the potential is very slight. The tract is in a "speculative" area for uranium potential (ERDA 1976). The rocks are too old for coal. Hot dry rock at. depth may be favorable as a source of geothermal energy. No critical minerals are known to occur on the tract, but it is close to the North Cove zinc deposits (Bryant and Reed 1966). Little exploration has occurred for any resources in the immediate area.

GEOLOGY: Surface rocks are primarily the Cambrian Chilhowee Group; some Precambrian Cranberry Gneiss along the east side of the tract.

REFERENCE/CITATION: Al1 resources - N.C. Dept. Conserv. and Develop., Div. Min. Res., 1959, Geol. Map of N.C.; USGS and USBMM,' 1968, UUSGS Prof. Paper 580; Miller and Others, 1970, Mineral Res. of the TVA Region; Bryant and Reed, 1970, USGS Prof. Paper 615; Brobst and Pratt, 1973, USGS Prof. Paper 820; DOE, 1978, Energy Res. Assessments of RARE II Lands; DOE, 1978, Energy Res. Assessments of Ten ATternatives - RARE II Lands; USFS, 1978, RARE II DES, So. Appal. Supp1. 0il and Gas - Vlissides and Quirin, 1963, 0il and Gas Fields of the U.S.; Cardwei1, 1971, AAPG Mem. 15; USGS, 1974 and 1975, Maps of Appal. 0 il and Gas Production; Miller and Others, 1975, USGS Circ. 725; Harris and Milici, 1977, USGS Prof. Paper 1018;. Patchen and Others, 1978, AAPG Bul1. 8. Uranium-Bryant and Reed, 1966, USGS Circ. 521; ERDA, 1976, NURE Preliminary Report. Coal - Trumbui1, 7960, Coal Fields of the U.S. Geothermal - AAPG, 1976a and b, Geothermal Gradient Map and Subsurface Temperature Map of North America. Critical Minerals - Lesure, 1968, USGS Prof. Paper 577; Orie1, 1950, N.C. Dept. Conserv. and Devel., Div. Min. Res., Bul1. 60. 
ENERGY AND MINERAL RESOURCE EVALUATION - RARE II TRACTS

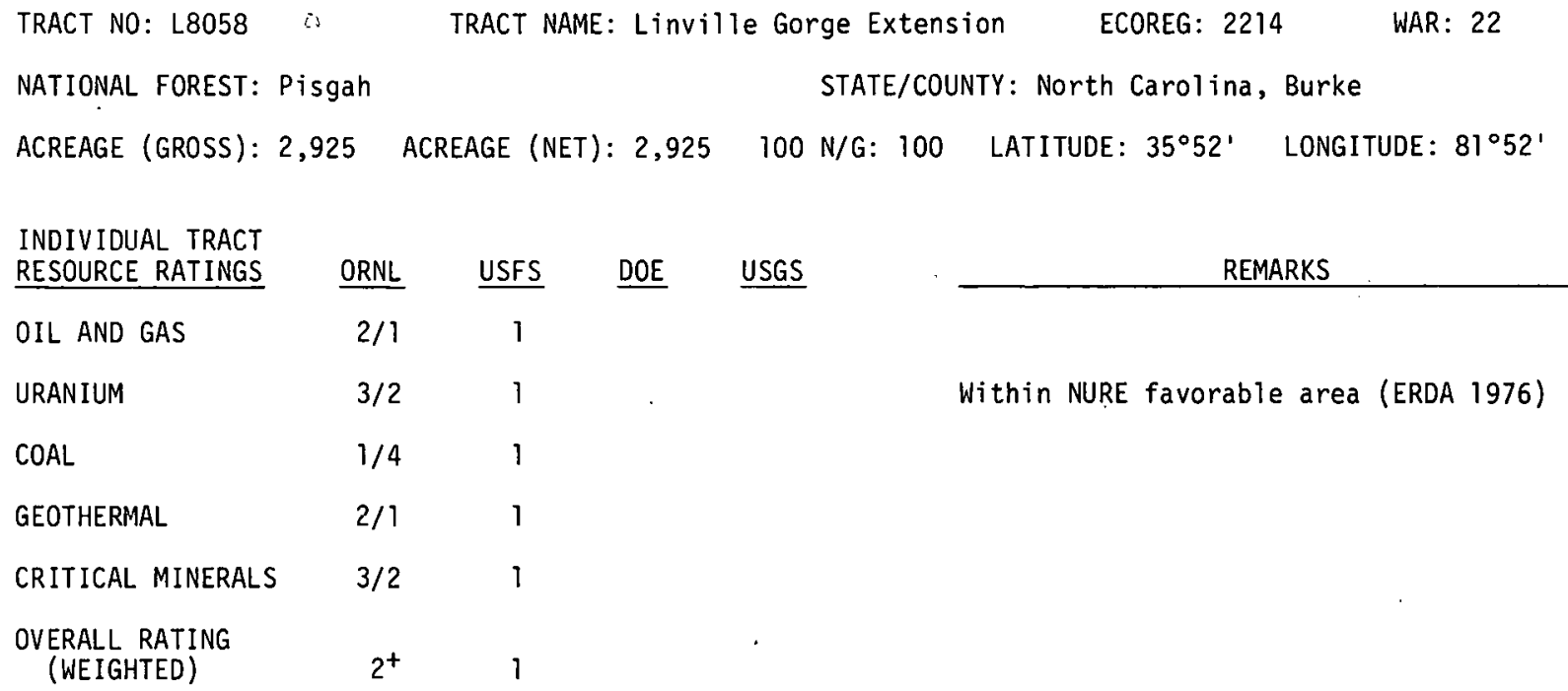

NAMES OF CRITICAL MINERALS PRESENT: POSsible mica, feldspar, rare earths

COMMENTARY AND SUMMARY: This tract is in the Blue Ridge province. The rocks below the basal Blue Ridge Thrust may be favorable for gas (Harris 1976). The tract is in an area favorable for uranium (ERDA 1976). The rocks are too old for coal. Hot dry rock at depth may be favorable as a source of geothermal energy. Pegmatites in the granite gneiss may contain mica, feldspar, and rare earths. Little exploration has occurred in the immediate area for any resources.

GEOLOGY: Surface rocks are Precambrian granite gneiss and Precambrian (?) and Cambrian Chilhowee Group sediments.

REFERENCE/CITATION: All resources - N.C. Dept. Conserv. and Develop., Div. Min. Res., 1959, Geol. Map of N.C.; USGS and USBM, 1968, USGS Prof. Paper 580; Miller and Others, 1970, Mineral Res. of the TVA Region; Bryant and Reed, 1970, USGS Prof. Paper 615; Brobst and Pratt, 1973, USGS Prof. Paper 820; DOE, 1978, Energy Res. Assessments of RARE II Lands; DOE, 1978, Energy Res. Assessments of Ten A1ternatives - RARE II Lands; USFS, 1978, RARE II DES, So. Appal. Suppl. 0il and Gas - Vlissides and Quirin, 1963, 0il and Gas Fields of the U.S.; Cardwell, 1971, AAPG Mem. 15; USGS, 1974 and 1975, Maps of Appal. Oil and Gas Production; Miller and Others, 1975, USGS Circ. 725; Harris and Milici, 1977, USGS Prof. Paper 1018; Patchen and 0thers, 1978, AAPG Bu11. 8. Uranium - Bryant and Reed, 1966, USGS Circ. 521; EROA, 1976, NURE Preliminary Report. Coal - Trumbul1, 1960, Coal Fields of the U.S. Geothermal - AAPG, 1976a and b, Geothermal Gradient Map and Subsurface Temperature Map of North America. Critical Minerals - Lesure, 1968, USGS Prof. Paper 577; Orie1, 1950, N.C. Dept. Conserv. and Devel., Div. Min. Res., Bul1. 60 . 
ENERGY AND MINERAL RESOURCE EVALUATION - RARE II TRACTS

TRACT N0: 08150

TRACT NAME: Iron Mountain

ECOREG: 2214 ,

WAR: 17

NATIONAL FOREST: Cherokee

STATE/COUNTY: Tennessee, Johnson

ACREAGE (GROSS): 13,700 ACREAGE (NET): $13,700 \quad 100 \mathrm{~N} / \mathrm{G}: 100$ LATITUDE: $36^{\circ} 33^{\prime}$ LONGITUdE: $81^{\circ} 51^{\prime}$

INDIVIDUAL TRACT

RESOURCE RATINGS

ORNL USFS DOE USGS

REMARKS

$\begin{array}{lll}\text { OIL AND GAS } & 3 / 1 & 1 \\ \text { URANIUM } & 2 / 1 & 1 \\ \text { COAL } & 1 / 4 & 1 \\ \text { GEOTHERMAL } & 2 / 1 & 1 \\ \text { CRITICAL MINERALS } & 4 / 4 & 1 \\ \begin{array}{c}\text { OVERALL RATING } \\ \text { (WEIGHTED) }\end{array} & 3 & \end{array}$

Shady Valley Manganese .District

(King and Ferguson 1960)

(WEIGHTED)

NAMES OF CRITICAL MINERALS PRESENT: Iron and manganese; possible zinc, lead, ard barite

COMMENTARY AND SUMMARY: This tract is in the Blue Ridge province. The rocks may be favorable for gas at depth below the basal Blue Ridge Thrust (Harris 1976). Sandstone and conglomerate units may be favorable for uranium. The rocks are too old for coal. Hot dry rock at depth may be favorable as a source of geothermal energy. The weathered Shady Dolomite contains milled deposits of manganese and iron ore and is quite favorable for zinc, lead, and barite (King and Ferguson 1960). Except for critical minerals, little exploration for resources has occurred.

GEOLOGY: Surface rocks are Lower Cambrian shales, sandstones, and carbonates of the Unicoi, Hampton, Erwin, and Shady formations on the southeastern flank of the Shady Valley syncline.

REFERENCE/CITATION: All resources - Hardeman and Others, 1966, Geol. Map of Tenn.; USGS and USBM, 1968, USGS Prof. Paper 580; Miller and 0thers, 1970, Mineral Res. of the TVA Region; Brobst and Pratt, 1973, USGS Prof. Paper 820; DOE, 1978, Energy Res. Assessments of RARE II Lands; D0E, 1978, Energy Res. Assessments of Ten Al ternatives - RARE II Lands; USFS, 1978, RARE II DES, So. Appal. Suppl. 0il and Gas - V1issides and Quirin, 1963, 0i1 and Gas Fields of the U.S.; Cardwe11, 1971, AAPG Mem. 15; USGS, $\overline{1974}$ and 1975, Maps of Appal. Oil and Gas Production; Miller and Others, 1975, USGS Circ. 725; Harris, 1976, J. Res. USGS, v. 4, no. 4; Harris and Milici, 1977, USGS Prof. Paper 1018; Van Den Berg and 0thers, 1978, AAPG Bu11. 62: 1340-55. Uranium - ERDA, 1976, NURE Preliminary Report. Coal - Trumbu11, 1960, Coal Fields of the U.S. Geothermal-AAPG, 1976a and b, Geothermal Gradient Map and Subsurface Temperature Map of North Am. CriticalMinerals - King and Ferguson, 1960, USGS Prof. Paper 311. 
ENERGY AND MINERAL RESOURCE EVALUATION - RARE II TRACTS

TRACT NO: 08170

TRACT NAME: Dry River

ECOREG : 2214

WAR: 16

NATIONAL FOREST: George Washington

STATE/COUNTY: West Virginia, Pendleton

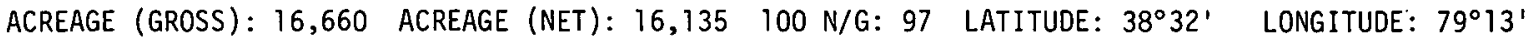

INDIVIDUAL TRACT

RESOURCE RATINGS

$\underline{O R N L} \quad \underline{\text { USFS }} \quad \underline{D O E} \quad \underline{\text { USGS }}$

REMARKS

OIL AND GAS

$3 / 2 \quad 1$

URANIUM

$2 / 1$

1

COAL

$1 / 4 \quad 1$

GEOTHERMAL

$2 / 1 \quad 1$

CRITICAL MINERALS $3 / 2 \quad 1$

Mineral-bearing rocks closer to surface

OVERALL RATING

(WEIGHTED)

2

NAMES OF CRITICAL MINERALS PRESENT: Possible copper; possible iron, zinc, lead, barite, fluorite, cadmium at depth

COMMENTARY AND SUMMARY: This tract is in the fold-dominated part of the valley and Ridge province. The rocks are quite favorable for oil and gas, al though some hydrocarbons may have been driven off by heat from metamorphism and igneous activity in the nearby Blue Ridge, heat that also made gas. more common than oil throughout the province. These hydrocarbons are produced in several places in the province in the study area. Sandstone units may be favorable for uranium. The rocks are too old to contain coal. Hot dry rock at depth may have some potential for geothermal energy. The Devonian Oriskany Sandstone at the surface may contain critical minerals manganese, iron, and zinc, and the Silurian Clinton Formation may contain iron. Critical minerals for which the subsurface rocks may be favorable include zinc, lead, cadmium, fluorite, and barite (Ordovician carbonates). Little exploration has occurred for any commodity, except oil and gas for which exploration has been moderate.

GEOLOGY: Surface rocks are Upper Devonian shales and sandstones on NW flank of a major syncline.

REFERENCE/CITATION: A11 resources - Stose and Ljungstedt, 1932, Geol. Map of W. Va.; USGS and USBM, 1968, USGS Prof. Paper 580; Miller and 0thers, 1970, Mineral Res. of the TVA Region; Brobst and Pratt, 1973, USGS Prof. Paper 820; DOE, 1978, Energy Res. Assessments of RARE II Lands; DOE, 1978, Energy Res. Assessments of Ten Alternatives - RARE II Lands; USFS, 1978, RARE II DES, So. Appa1. Supp 1. 0il and Gas - Vlissides and Quirin, 1963, 0il and Gas Fields of the U.S.; Cardwel1, 1971, AAPG Mem. 15; USGS, 1974 and 1975, Maps of Appal. 011 and Gas Production; Miller and Others, 1975, USGS Circ. 725; Harris and Milici, 1977, USGS Prof. Paper 1018; Patchen and Others, 1978, AAPG Bul1. 62: 1399-1441. Uranium - ERDA, 1976, NURE Preliminary Report. Coal - Trumbu11, 1960, Coal Fields of the U.S. Geothermal - AAPG, 1976a and b, Geothermal Gradient Map and Subsurface Temperature Map of North America. 
NATIONAL TOREST: Washington

ACREAGE (GROSS): 7,900 ACREAGE (NET): 7,900
STATE/COUNTY: Virginia, Alleghany

$100 \mathrm{~N} / \mathrm{G}: 100$ LATITUDE: $37^{\circ} 50^{\prime}$ LUNGITUDE: $79^{\circ} 56^{\prime}$

INDIVIDUAL TRACT

RESOURCE RATINGS

\section{$\underline{\text { ORNL }}$}

$3 / 2$

OIL AND GAS

IIRANTIIM

COAL

GEOTHERMAL

CRITICAL MINERALS

UVERALL RAIING

(WEIGHTED)

$? / 1 \quad 1$

$1 / 4 \quad 1$

$2 / 2 \quad 1$

$2 / 1 \quad 1$

$1^{+}$
REMARKS

In area of warm springs

NAMES OF CRITICAL MINERALS PRESENT: Possible manganese, zinc, lead, cadmium, fluorite, and barite at depth

COMMENTARY AND SUMMARY: This tract is in the fold-dominated part of the Valley and Ridge province. The rocks are quite favorable for oil and gas, al though some hydrocarbons may have been driven off by heat from metamorphism and igneous activity in the nearby Blue Ridge, heat that also made gas more common that oil throughout the province. These hydrocarbons are produced in several places in the province in the study area. Sandstone units may be favorable for uranium. The rocks are too old to contain coal. Warm springs in the area suggest that there is potential for geothermal energy. Critical minerals for which the subsurface rocks may be favorable include iron (Silurian Clinton Formation) and zinc, lead, cadmium, fluorite, and barite (Urdovician carbonates). Lietle expiorazion ior any commodity has occurred except for oil and gas, for which exploration has been moderate.

GEOLOGY: Surface rocks are Upper Ordovician to Lower Devonian shales and sandstones anticlinally folded.

REFERENCE/CITATION: Al1 resources - Milici and Others, 1963, Geol. Map of Va.; Gooch and Pharr, 1959, Mineral Indus. and ReS. of Vä.; USGS and USBM, 1968, USGS Prof. Paper 580; Miller and 0thers, 1970, Mineral Res. of the TVA Region; Brobst and Pratt, 1973, USGS Prof. Paper 820; D0E, 1978, Energy Res. Assessments of RARE II Lands; DOE, 1978, Energy Res. Assessments of Ten Alternatives - RARE II Lands; USFS, 1978, RARE II DES, So. Appal. Suppl. Oil and Gas - V1issides and Quirin, 1963, 0i] and Gas Fielis of the U.S.; Cardwe11, 1971. AAPG Mem. 15; USGS, 1974 and 1975, Maps of Appal. 0il and Gas Production; Miller and Others, 1975, USGS Circ. 725; Harris and Milici, 1977, USGS Prof. Paper 1018; Patchen and 0thers, 1978, AAPG Bu11. 8. Uranium - ERDA, 1976, NURE Prel iminary Report. Coal Trumbu11, 1960, Coal Fields of the U.S. Geothermal - AAPG, 1976a and b, Geothermal Gradient Map and Subsurf. Temp. Map of $\mathrm{N}$. Am. Critical Minerals-Lesure, 1957, V.P.I. Bull., Eng. Expt. Sta. series 118; Worl and Others, 1968, Fluorite Deposits of the U.S.; Lesure and 0thers, 1978, U.S.G.S. Bull. $1397 c$. 
ENERGY AND MINERAL RESOURCE EVALUATION - RARE II TRACTS

TRACT NO: 08172

TRACT NAME: Elliott Knob

ECOREG: 2214

WAR: 20

NATIONAL FOREST: Washington

STATE/COUNTY: Virginia, Augusta

ACREAGE (GROSS): 12,075 ACREAGE (NET): $12,075100 \mathrm{~N} / \mathrm{G}: 100$ LATITUDE: $38^{\circ} 10^{\prime}$ LONGITUDE: $79^{\circ} 19^{\prime}$

INDIVIDUAL TRACT

RESOURCE RATINGS

$\begin{array}{lll}\text { OIL AND GAS } & 3 / 2 & 1 \\ \text { URANIUM } & 2 / 1 & 1 \\ \text { COAL } & 1 / 4 & 1 \\ \text { GEOTHERMAL } & 2 / 1 & 1 \\ \text { CRITICAL MINERALS } & 2 / 1 & 1 \\ \begin{array}{l}\text { OVERALL RATING } \\ \quad \text { (WEIGHTED) }\end{array} & & \\ \quad 1^{+} & \end{array}$

NAMES OF CRITICAL MINERALS PRESENT: Possible copper; possible manganese, iron, lead, zinc, cadmium, fluorite, and barite at depth

COMMENTARY AND SUMMARY: This tract is in the fold-dominated Valley and Ridge. The rocks are quite favorable for oil and gas, although some hydrocarbons may have been driven off by heat from metamorphism and igneous activity in the nearby Blue Ridge, heat that also made gas more common than oil throughout the province. These hydrocarbons are produced in several places in the province in the study area. Sandstone units may be favorable for uranium. The rocks are too old to contain coal. Hot dry rock at depth may have some potential for geothermal energy. Upper Devonian red beds may contain the critical mineral copper. Criticial minerals for which the subsurface rocks may be favorable include zinc and lead (Devonian Oriskany Sandstone); iron (Devonian Helderberg Limestone ánd Silurian Clinton Formation); and zinc, cadmium, lead, fluorite, and barite (Ordovician carbonates). In the vicinity of the tract, little exploration has occurred except for oil and gas, for which exploration has been moderate.

GEOLOGY: Surface rocks are Upper Devonian and Lower Mississippian shales and sandstones synclinally folded.

REFERENCE/CITATION: All resources - Milici and Others, 1963, Geol. Map of Va.; Gooch and Pharr, 1959, Mineral Indus. and Res. of Va.; USGS and USBM, 1968, USGS Prof. Paper 580; Miller and Others, 1970, Mineral Res. of the TVA Region; Brobst and Pratt, 1973, USGS Prof. Paper 820; D0E, 1978, Energy Res. Assessments of RARE II Lands; DOE, 1978, Energy Res. Assessments of Ten Alternatives - RARE II Lands; USFS, 1978, RARE II DFS, Sn. Appal. Suppl, 0il and Gas - VIissides and Quirin, 1963, 0il and Gas Fields of the U.S.; Cardwell, 1971, AAPG Mem. 15; USGS, 1974 and 1975, Maps of Appal. 0i1 and Gas Production; Miller and 0thers, 1975, USGS Circ. 725; Harris and Milici, 1977, USGS Prof. Paper 1018; Patchen and 0thers, 1978, AAPG Bu11. 8. Uranium - ERDA, 1976, NURE Prel iminary Report. Coal -

Trumbu11, 1960, Coal Fields of the U.S. Geothermal - AAPG, 1976a and b, Geothermal Gradient Map and Subsurf. Temp. Map of N. Am. Critical Minerals-Lesure, 1957, V.P.I. Bu11., Eng. Expt. Sta. series 118; Worl and 0thers, 1968, Fluorite Deposits of the U.S.; Lesure and Others, 1978, U.S.G.S. Bull. $1397 c$. 
ENERGY AND MINERAL RESOURCE EVALUATION - RARE II TRACTS

TRACT NO: 08173

TRACT NAME: Head of Dry River

ECOREG: 2214

WAR: 21

NATIONAL FOREST: Washington

STATE/CUUNTY: Virginia, RUckingham

ACREAGE (GROSS): 1,300 ACREAGE (NET): $1,300 \quad 100 \mathrm{~N} / \mathrm{G}: 100$ LATITUDE: $38^{\circ} 31^{\prime}$ LONGITUDE: $79^{\circ} 13^{\prime}$

INDIVIDUAL TRACT

RESOURCE RATINGS

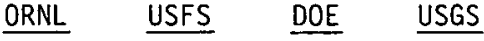

REMARKS

OIL AND GAS

$3 / 2 \quad 1$

URANIUM

$2 / 1$

1

CONL

$1 / 4 \quad 1$

GEOTHERMAL

2/1. 1

CRITICAL MINERALS

$3 / 1$

1

OVERALL RATING

(WEIGHTED)

$1^{+}$

NAMES OF CRITICAL MINERALS PRESENT: Possible copper; possible iron, lead, manganese, zinc, cadmium, barite, and fluorite at depth

COMMENTARY AND SUMMARY: This tract is in the fold-dominated Valley and Ridge. The rocks are quite favorable for oil and gas, although some hydrocarbons may have been driven off by heat from metamorphism and igneous activity in the nearby Blue Ridge, heat that also made gas more common than oil throughout the province. These hydrocarbons are produced in several places in the province in the study area. Sandstone units may be favorable for uranium. The rocks are too old to contain coal. Hot dry rock at depth may have some potential for geothermal energy. Upper Devonian red beds may contain the critical mineral copper. Criticial minerals for which the subsurface rocks may be favorable include zinc and lead (Devonian Oriskany Sandstone); iron (Devonian HeIderberg Limestone and Silurian Clinton Formation); and zinc, cadmium, lead, fluorite, and barite (Ordovician carbonates). In the vicinity of the tract, little exploration has occurred except for oil and gas, for which exploration has been moderate.

GEOLOGY: Surface rocks are sandstones and shales of Upper Devonian age, with some Lower Mississippian sandstones, essentially flat-lying within a major syncline.

REFERENCE/CITATION: All resources - Milici and 0thers; 1963, Geol. Map of Va.; Gooch and Pharr, 1959, Mineral Indus. and ReS. of Va.; USGS and USBM, 1968, USGS Prof. Paper 580; Milier and 0thers, 1970, Mineral Res. of the TVA Region; Brobst and Pratt, 1973, USGS Prof. Paper 820; DOE, 1978, Energy Res. Assessments of RARE 11 Lands; UUt, Iy78, tnergy kes. Assessments of Ten Alternatives - RARE. II Lands; USFS, 1978, RARE II DES, So. Appal. Suppl. Oil and Gas ...V1 issides and Quirin, 1963, 0il and Gas Fields of the U.S.; Cardwel1, 1971, AAPG Mem. 15; USGS, 1974 and 1975, Maps of Appal. 0i1 and Gas Production; Miller and Others, 1975, USGS Circ. 725; Harris and Milici, 1977, USGS Prof. Paper 1018; Patchen and Others, 1978, AAPG Bul1. 8. Uranium - ERDA, 1976, NURE Preliminary Report. Coal Trumbul1, 1960, Coal Fields of the U.S. Geothermal - AAPG, 1976a and b, Geothermal Gradient Map and Subsurf. Temp. Map of N. Am. Critical Minerals - Lesure, 1957, V.P.I. Bull., Eng. Expt. Sta. series 118; Worl and Others, 1968, Fluorite Deposits of the U.S.; Lesure and Others, 1978, U.S.G.S. Bull. $1397 \mathrm{c}$. 
ENERGY AND MINERAL RESOURCE EVALUATION - RARE II TRACTS

TRACT NO: 08174

TRACT NAME: Ramseys Draft (Addition)

ECOREG: 2214

WAR: 21

NATIONAL FOREST: Washington

STATE/COUNTY: Virginia, Highland/Augusta

ACREAGE (GROSS): 13,475 ACREAGE (NET): $13,475 \quad 100 \mathrm{~N} / \mathrm{G}: 100$ LATITUDE: $38^{\circ} 20^{\prime}$ LONGITUDE: $79^{\circ} 20^{\prime}$

INDIVIDUAL TRACT

RESOURCE RATINGS

\begin{tabular}{cr} 
ORNL & USF \\
\hline $3 / 2$ & 1 \\
$2 / 1$ & 1 \\
$1 / 4$ & 1 \\
$2 / 1$ & 1 \\
$3 / 2$ & 1 \\
& \\
$2-$ &
\end{tabular}

$\underline{D O E} \quad \underline{\text { USGS }}$

REMARKS

OIL AND GAS

1

URANIUM

1

COAL

1

GEOTHERMAL

1

CRITICAL MINERALS

1

OVERALL RATING

(WEIGHTED)

NAMES OF CRITICAL MINERALS PRESENT: Possible copper; possible zinc, cadmium, lead, manganese, iron, fluorite, and barite at depth

COMMENTARY AND SUMMARY: This tract is in the fold-dominated Valley and Ridge. The rocks are quite favorable for oil and gas, al though some hydrocarbons may have been driven off by heat from metamorphism and igneous activity in the nearby Blue Ridge, heat that also made gas more common than oil throughout the province. These hydrocarbons are produced in several places in the province in the study area. Sandstone units may be favorable for uranium. The rocks are too old to contain coal. Hot dry rock at depth may have some potential for geothermal energy. Upper Devonian red beds may contain the critical mineral copper. Criticial minerals for which the subsurface rocks may be favorable include zinc and lead (Devonian Oriskany Sandstone); iron (Devonian Helderberg Limestone and Silurian Clinton Formation); and zinc, cadmium, lead, fluorite, and barite (Ordovician carbonates). In the vicinity of the tract, little exploration has occurred except for oil and gas, for which exploration has been moderate.

GEOLOGY: Surface rocks are Upper Devonian shales and sandstones synclinally folded.

REFERENCE/CITATION: All resources - Milici and Others, 1963, Geol. Map of Va.; Gooch and Pharr, 1959, Mineral Indus. and Res. of Va.; USGS and USBM, 1968, USGS Prof. Paper 580; M11ler and 0thers, 1970, Mineral Res. of the TVA Region; Brobst and Pratt, 1973, USGS Prof. Paper 820; D0E, 1978, Energy Res. Assessments of RARE II Lands; DOE, 1978, Energy Res. Assessments of Ten Alternatives - RARE II Lands; USFS, 1978, RARE II DES, So. Appal. Suppl. 0i1 and Gas - Vlissides and Ouirin, 1963, 0il and Gas Fields of the U.S.; Cardwe11, 1971, AAPG Mem. 15; USGS, 1974 and 1975, Maps of Appal. 0i1 and Gas Production: Miller and Others, 1975, USGS Circ. 725; Harris and Milir.i, 1977, USGS Prof. Paper 1018; Patchen and Others, 1978, AAPG Bu11. 8. Uranium - ERDA, 1976, NURE Preliminary Report. Coal Trumbul1, 1960, Coal Fields of the U.S. Geothermal - AAPG, 1976a and b, Geothermal Gradient Map and Subsurf. Temp. Map of N. Am. Critical Minerals-Lesure, 1957, V.P.I. Bull., Eng. Expt. Sta. series 118; Worl and Others, 1968, Fluorite Deposits of the U.S.; Lesure and Others, 1978, U.S.G.S. BuT1. $1397 c$. 
ENERGY AND MINERAL RESOIIRCE EVALUATION - RARE II TRACTS

TRACT NO: 08180

TRACT NAME: Devils Fork

ECOREG : 2214

WAR: 18

NATIONAL FOREST: Jefferson

STATE/COUNTY: Virginia, Scott

ACREAGE (GROSS): 5,887 ACREAGE (NET): $4,750 \quad 100 \mathrm{~N} / \mathrm{G}: 81$ LATITUDE: $36^{\circ} 49^{\prime}$ LONGITUDE: $82^{\circ} 39^{\prime}$

INDIVIDUAL TRACT

KESUURCE RATINGS

$\underline{O R N L} \quad \underline{\text { USFS }} \quad \underline{\mathrm{DOE}} \quad \underline{\text { USGS }}$

REMARKS

OIL AND GAS

$4 / 2 \quad 1$

Pine Mountain overthrust has trapped gas in Wise County. Tract is on SE border ur Aupdlachian lás and Uil Field (USGS $\lceil y / 4,1975)$

$\begin{array}{llll}\text { URANIUM } & 2 / 2 & 1 & 2 \\ \text { COAL } & 4 / 4 & 1 & 2 \\ \text { GEOTHERMAL } & 2 / 1 & 1 & \\ \begin{array}{l}\text { CRITICAL MINERALS } \\ \begin{array}{l}\text { OVERALL RATING } \\ \text { (WEIGHTED) }\end{array}\end{array} & 2 / 1 & 1 & \\ \end{array}$

Tract is within Appalachian coal field

NAMES OF CRITICAL MINERALS PRESENT: Possible copper, iron, zinc; lead, cadmium, fluorite, and barite at depth

COMMENTARY AND SUMMARY: This tract is in the thrust fault-dominated part of the Valley and Ridge province. The rocks are quite favorable for oil and gas, al though some hydrocarbons may have been driven off by heat from metamorphism and igneous activity in the nearby Blue Ridge, heat that also made gas more common than oil throughout the province. These hydrocarbons are produced in several places in the province in the study area. Exploration overall has been fairly meager. This tract has unusually high favorability because of its location with respect to a gas-producing anticline. Sandstone units may be favorable for uranium but little exploration has occurred. This tract is located within the Appalachian coal field and overlies minable, thick, high-quality coal. Hot dry rock at depth may have some potential for geothermal energy, but little exploration has taken place. The surface rocks probably contain no critical minerals. The subsurface rocks may be favorable for copper (Upper Devonian red beds); zinc (Devonian Oriskany sandstone); iran (Silurian Clinton Formation); and zinc, lead, cadmium, fluorite, and barite (Cambro-Ordovician carbonates); little exploration has been performed.

GEOLOGY: Surface rocks are synclinally folded Lower Pennsyivanian sandstones and shales in the Upper plate of the Pine Mountain overthrust.

REFERENCE/CITATION: All resources - Milici and Others, 1963, Geol. Map of Va.; Gooch and Pharr, 1959, Mineral Indus. and ReS. of Va.; USGS and USBM, 1968, USGS Prof. Paper 580; Miller and Others, 1970, Mineral Res. of the TVA Region; Brobst and Pratt, 1973, USGS Prof. Paper 820; D0E, 1978, Energy Res. Assessments of RARE II Lands; DOE, 1978, Energy Res. Assessments of Ten Alternatives - RARE II Lands; USFS, 1978, RARE II DES, So. Appal. Suppl. Dil and Gas - Vlissides and Quirin, 1963, 0il and Gas Fields of the U.S.; Cardwe11, 1971, AAPG Mem. 15; USGS, 1974 and 1975, Maps of Appal. 0il and Gas Production; Miller and Others, 1975, USGS Circ. 725; Harris and Milici, 1977, USGS Prof. Paper 1018; Patchen and Others, 1978, AAPG Bu11. 8. Uranium - ERDA, 1976, NURE Prel iminary Report. Coal Trumbu1 1, 1960, Coal Fields of the U.S. Geothermal - AAPG, 1976a and b, Geothermal Gradient Map and Subsurf. Temp. Map of N. Am. Critical Minerals-Lesure, 1957, V.P.I. Bull., Eng. Expt. Sta. series 118; Worl and Others, 1968, Fluorite Deposits of the U.S.; Lesure and 0thers, 1978, U.S.G.S. Bul1. 1397c. 
ENERGY AND MINERAL RESOURCE EVALUATION - RARE II TRACTS

TRACT NO: 08181 .

TRACT NAME: Big Stoney

ECOREG : 221.4

WAR: 18

NATIONAL FOREST: Jefferson

ACREAGE (GROSS): 4,115 ACREAGE (NET): 4,065
STATE/COUNTY: Virginia, Scott/Wise

$100 \mathrm{~N} / \mathrm{G}: 99$ LATITUDE: $36^{\circ} 52^{\prime}$ LONGITUDE: $82^{\circ} 35^{\prime}$
INDIVIDUAL TRACT

RESOURCE RATINGS

OIL AND GAS

ORNL

$\underline{\text { USFS }}$

$\underline{D O E}$

$\underline{\text { USGS }}$

$4 / 2 \quad 1$

URANIUM

COAL

GEOTHERMAL

CRITICAL MINERALS

$2 / 2$

$4 / 4$

$2 / 1$

$2 / 1$

$2^{+}$

OVERALL RATING

(WE IGHTED)

1
1
1
1

2

2
REMARKS

Pine Mountain overthrust block contains gas in Wise County

Tract lies within Appalachian Coal Field

NAMES OF CRIITICAL MINERALS PRESENT: Possible copper, zinc, iron, cadmium, lead, fluorite, and barite at depth

COMMENTARY AND SUMMARY: This tract is in the thrust fault-dominated part of the Valley and Ridge province. The rocks are favorable for $0 i l$ and gas, which are produced in this part of the province. Sandstone units may be favorable for uranium. This tract is on the Appalachian coal field overlying thick, minable, high-quality coal. Hot dry rock at depth may be favorable as a source of geothermal energy. The surface rocks probably contain no critical minerals, but older rocks at depth may be favorable for copper (Upper Devonian red beds); zinc and lead (Devonian Oriskany Sandstone); iron (Devonian Helderberg Limestone and Silurian Clinton Formation); and zinc, cadmium, lead, fluorite, and barite (Ordovician carbonates). Little exploration has occurred in the immediate area for any resources except for oil, gas, and coal, for which there has been large exploration.

GEOLOCY: Surface rocks are Lower Pennsylvanian sandstone and shale, synclinally folded, in the upper plate of the Pine Mountain overthrust.

REFERENCE/CITATION: All resources - Milici and Others, 1963, Geol. Map of Va.; Gooch and Pharr, 1959, Mineral Indus. and ReS. of Va.; USGS and USBM, 1968, USGS Prof. Paper 580; Miller and 0thers, 1970, Mineral Res. of the TVA Region; Brobst and Pratt, 1973, USGS Prof. Paper 820; D0E, 1978, Energy Res. Assessments of RARE II Lands; D0E, 1978, Energy Res. Assessments of Ten Alternatives - RARE II Lands; USFS, 1978, RARE II D[S, So. Appal. Suppl. Dil and Gas - Vlissides and Quirin, 1963, 0i1 and Gas Fields of the U.S.; Cardwell, 1971, AAPG Mem. 15; USGS, 1974 and 1975, Maps of Appal. 0i1 and Gas Production; Miller and Others, 1975, USGS Circ. 725; Harris and Milici, 1977, USGS Prof. Paper 1018; Patchen and Others, 1978, AAPG Bu11. 8. Uranium - ERDA, 1976, NURE Prel iminary Report. Coa 1 Trumbu11, 1960, Coal Fields of the U.S. Geothermal - AAPG, 1976a and b, Geothermal Gradient Map and Subsurf. Temp. Map of N. Am. Critical Minerals-Lesure, 1957, V.P.I. Bull., Eng. Expt. Sta. series 118; Worl and Others, 1968, Fluorite Deposits of the U.S.; Lesure and 0thers, 1978, U.S.G.S. Bul1. 1397 c. 
NATIONAL FOREST: Jefferson

ACREAGE (GROSS): 5,726 ACREAGE (NET): 5,580
STATE/COUNTY: Virginia, Bland

$100 \mathrm{~N} / \mathrm{G}: 98$ LATITUDE: $37^{\circ} 11^{\prime}$ LONGITUDE: $81^{\circ} 05^{\prime}$

\begin{tabular}{|c|c|c|c|}
\hline $\begin{array}{l}\text { INDIVIDUAL TRACT } \\
\text { RESOURCE RATINGS }\end{array}$ & ORNL & USFS & USGS \\
\hline OIL AND GAS & $3 / 2$ & ? & \\
\hline URANIUM & $2 / 1$ & 1 & \\
\hline COAL & $1 / 4$ & 1 & \\
\hline GEOTHERMAL & $2 / 1$ & 1 & \\
\hline CRITICAL MINERALS & $2 / 1$ & 1 & \\
\hline $\begin{array}{l}\text { OVERALL RATING } \\
\text { (WEIGHTED) }\end{array}$ & $1^{+}$ & & \\
\hline
\end{tabular}

REMARKS

NAMES OF CRITICAL MINERALS PRESENT: Possible zinc, iron, lead, cadmium, barite, and fluorite at depth

COMMENTARY AND SIJMMARY: This tract is in the thrust fault-dominated part of the Valley and Ridge province. The rocks are quite favorable for oil and gas. Sandstone units may be favorable for uranium. The rocks are too old for coal. Hot dry rock at depth may be favorable as a source of geothermal energy. The surface rocks probably contain no critical minerals. Critical minerals for which the subsurface rocks may be favorable include zinc and lead (D̄evonian Oriskany Sandstone); iron (Devonian Helderberg Limestone and Silurian Clinton Formation); and zinc, lead, cadmium, barite, and fluorite (Ordovician carbonates). Except for oil and gas, little exploration has occurred for resources in the immediate area.

GEOLOGY: Surface rocks are Middle Devọnian șąles and șandștones anticlinally folded.

REFERENCE/CITATION: All resources - Milici and 0thers, 1963, Geol. Map of Va.; Gooch and Pharr, 1959, Mineral Indus. and ReS. of Va.; USGS and USBM, 1968, USGS Prof. Paper 580; Miller and 0thers, 1970, Mineral Res. of the TVA Region; Brobst and Pratt, 1973, USGS Prof. Paper 820; D0E, 1978, Energy Res. Assessments of RARE II Lands; DOE, 1978, Energy Res. Assessments of Ten Alternatives - RARE II Lands; USFS, 1978, RARE II DES, So. Appa1. Suppl. Oil and Gas - Vlissides and Quirin, 1963, 0il and Gas Fields of the U.S.; Cardwel1, 1971. AAPG Mem. 15: USGS. 1974 and 1975. Maps of Appal. 0il and Gas Production; Miller and 0thers, 1975, USGS Circ. 725; Harris and Milici, 1977, USGS Prof. Paper 1018; Patchen and 0thers, 1978, AAPG Bu11.8. Uranium - ERDA, 1976, NURE Prel iminary Report. Coal Trumbul1, 1960, Coal Fields of the U.S. Geothermal - AAPG, 1976a and b, Geothermal Gradient Map and Subsurf. Temp. Map of N. Am. Critical Minerals-Lesure, 1957, V.P.I. Bull., Eng. Expt. Sta. series 118; Worl and Others, 1968, Fluorite Deposits of the U.S.; Lesure and Others, 1978, U.S.G.S. Bul1. $1397 \mathrm{c}$. 
INDIVIDUAL TRACT RESOURCE RATINGS

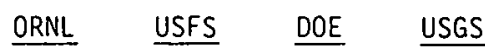

$3 / 2 \quad 1$.

URANIUM

COAL

GEOTHERMAL

CRITICAL MINERALS $\quad 3 / 2 \quad 4$

CRITICAL MINERALS $3 / 2 \quad 4$

OVERALL RATING

(WEIGHTED)
$2 / 1$

1

2/1 1

$1 / 4 \quad 1$

11
Eight miles along strike from Clifton
Forge Iron Area (Lesure 1957)

NAMES OF CRITICAL MINERALS PRESENT: Possible zinc, manganese, iron, lead, cadmium, barite, and fluorite

COMMENTARY AND SUMMARY: This tract is in the thrust fault-dominated part of the Valley and Ridge province. The rocks are quite favorable for oil and gas. Sandstone units may be favorable for uranium. The rocks are too old for coal. Hot dry rock at depth may be favorable as a source of geothermal energy. The surface rocks are favorable for critical minerals: zinc, manganese, and lead in the weathered Devonian Oriskany Sandstone; iron in the Devonian Helderberg Limestone and Silurian Clinton Formation: and zinc, lead, cadmium, barite, and fluorite in the Ordovician carbonates. Considerable exploration and production of iron has occurred nearby in the Clifton Forge area (Lesure 1957), but itttle exploration has been performed in the immediate area for other resources.

GEOLOGY: Surface rocks are Ordovician to Middle Devonian limestones, shales, and sandstones in complex ariliclines and synclines.

REFERENCE/CITATION: All resources - Milici and Others, 1963, Geol. Map of Va.; Gooch and Pharr, 1959, Mineral Indus, and Res, of Va.; USGS and USBM, 1968, USGS Prof. Paper 580; Miller and 0thers, 1970, Mineral Res. of the TVA Region; Brobst and Pratt, 1973, USGS Prof. Paper 820; DOE, 1978, Energy Res. Assessments of RARE II Lands; DOE, 1978, Energy Res. Assessments of Ten A1ternatives - RARE II Lands; USFS, 1978, RARE II DES, So. Appal. Suppl. Oil and Gas - VI issides and Quirin, 1963, 0il and Gas Fields of the U.S.; Cardwel1, 1971, AAPG Mem. 15; USGS, 1974 and 1975, Maps of Appal. 0il and Gas Production; Miller and Others, 1975, USGS Circ. 725; Harris and Milici, 1977, USGS Prof. Paper 1018; Patchen and 0thers, 1978, AAPG Bu11. 8. Uranium - ERDA, 1976, NURE Prel iminary Report. Coal Trumbu11; 1960, Coal Fields of the U.S. Geothermal - AAPG, 1976a and b, Geothermal Gradient Map and Subsurf. Temp. Map of N. Am. Critical Minerals-Lesure, 1957, V.P.I. Bull., Eng. Expt. Sta. series 118; Worl and Others, 1968, Fluorite Deposits of the U.S.; Lesure and 0thers, 1978, U.S.G.S. Bull. $1397 \mathrm{c}$. 
ENERGY AND MINERAL RESOURCE EVALUATION - RARE II TRACTS

TRACT iNO: 08184

TRACT NAME: Hoop Hole

ECOREG : 2214

WAR: 17

NATIONAL FOREST: George Washington

STATE/COUNTY: Virginia, Alleghany

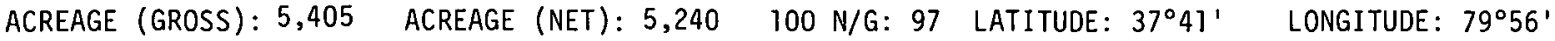

INDIVIDUAL TRACT

RESOURCE RATINGS

ORIL USFS UÜE USGS

OIL AND GAS

$3 / 2 \quad 1$

UIRAN I IIM

$2 / 1$

1

KEMAKKS

r.nAl

$1 / 4$

1

GEOTHERMA

$2 / 1$

1

CRITICAL MINERALS

$3 / 2$

4

In Clifton Forge Iron-Manganese District (Lesure $\mid y_{b} /$ ), Uriskany (Kidgely) exposed

OVERALL RATING

(WEIGHTED)

$2^{+}$

Gas pipeline crosses the tract

NAMES OF CRITICAL MINERALS PRESENT: Possible manganese, iron, zinc, lead, and barite; possible iron, zinc, cadmium, lead, fluorite, and barite at depth

COMMENTARY AND SUMMARY: This tract is in the fold-dominated part of the Valley and Ridge province. The rocks are quite favorable for $0 i 1$ and gas, al though some hydrocarbons may have been driven off by heat from metamorphism and igneous activity in the nearby Blue Ridge, heat that also made gas more common than oil throughout the province. These hydrocarbons are produced in several places in the province in the study area. Sandstone units may be favorable for uranium. The rocks are too old to contain coal. Hot dry rocks at depth may have some potential for geothermal energy. Critical minerals for which the surface rocks are favorable include manganese, lead, and zinc (Devonian Oriskany Sandstone); iron (Devonian Helderberg Limestone and Silurian Clinton Formation); and zinc, lead, cadmium, fluorite, and barite (Ordovician carbonates). Considerable exploration for, and production of, iron and manganese has taken place in the surrounding area. For everythinq else except oil and gas, little exploration has occurred, and for oil and gas, exploration has only been moderate.

GEOLOGY: Surface rocks are Ordovician to Middle Devonian limestones, shales, and sandstones anticlinally and synclinally folded.

REFERENCE/CITATION: All resources - Milici and Others, 1963, Geol. Map of Va.; Gooch and Pharr, 1959, Mineral Indus, and ReS. of Va.; USGS and USBM, 1968, USGS Prof. Paper 580; Miller and Others, 1970 , Mineral Res. of the TVA Region; Brobst and Pratt, 1973, USGS Prof. Paper 820; D0E, 1978, Energy Res. Assessments of RARE II Lands; DOE, 1978, Energy Res. Assessments of Ten A1ternatives - RARE II Lands; USFS, 1978, RARE II DES, So. Appal. Suppl. Oil and Gas - V1issides and quirin, 1963, 0il and Gas Fields of the U.S.; Cardwel1, 1971, AAPG Mem. 15; USGS, 1974 and 1975, Maps of Appal. 0il and Gas Production; Miller and Others, 1975, USGS Circ. 725; Harris and Milici, 1977, USGS Prof. Paper 1018; Patchen and 0thers, 1978, AAPG Bu11. 8. Uranium - ERDA, 1976, NURE Prel iminary Report. Coal Trumbu11, 1960, Coal Fields of the U.S. Geothermal - AAPG, 1976a and b, Geothermal Gradient Map and Subsurf. Temp. Map of N. Am. Critical Minerals-Lesure, 1957, V.P.I. Bull., Eng. Expt. Sta. series 118; Worl and 0thers, 1968, Fluorite Deposits of the U.S.; Lesure and Others, 1978, U.S.G.S. Bul1. $1397 \mathrm{c}$. 
ENERGY AND MINERAL RESOURCE EVALUATION - RARE II TRACTS

TRACT NO: 08185

TRACT NAME: Thunder Ridge

ECOREG: 2214

WAR: 19

NATIONAL FOREST: Jefferson

STATE/COUNTY: Virginia, Botetourt/Rockbridge

ACREAGE (GROSS) $: 2,530$ ACREAGE (NET): 2,530

$100 \mathrm{~N} / \mathrm{G}: 100$ LATITUDE: $37^{\circ} 32^{\prime}$ LONGITUDE: $79^{\circ} 30^{\prime}$

INDIVIDUAL TRACT

RESOURCE RATINGS

$\underline{\text { ORNL }} \underline{\text { USFS }} \underline{\text { DOE }} \underline{\text { USGS }}$

REMARKS

OIL AND GAS

$2 / 1$. 1

URANIUM

$3 / 1 \quad 1$

Pedlar Gneiss favorable (ERDA 1976)

COAL

$1 / 4 \quad 1$

GEOTHERMAL

2/1 1

CRITICAL MINERALS

$2 / 1$

1

OVERALL RATING

(WEIGHTED)

$1^{+}$

NAMES OF CRITICAL MINERALS PRESENT: POSsible mica, feldspar, and rare earths

COMMENTARY AND SUMMARY: This tract is in the Blue Ridge province. The rocks below the basal Blue Ridge Thrust may be favorable for gas (Harris 1976). The Pedlar Gneiss is favorable for uranium (ERDA 1976), which may be present in veins. The rocks are too old for coal. Hot dry rock at depth may be favorable as a source of geothermal energy. No critical minerals are known to exist in the tract, but pegmatite veins could contain mica, feldspar, and rare earths. Little exploration has occurred for any resources in the immediate area.

GEOLOGY: Surface rock is the Precambrian Pedlar Gneiss.

REFERENCE/CITATION: All resources - Milici and 0thers, 1963, Geol. Map of Va.; Gooch and Pharr, 1959, M1neral Indus. and Res. of Va.; USGS and USBM, 1968, USGS Prof. Paper 580; Miller and 0thers, 1970, Mineral Res. of the TVA Region; Brobst and Pratt, 1973, USGS Prof. Paper 820; D0E, 1978, Energy Res. Assessments of RARE II Lands; DOE, 1978, Energy Res. Assessments of Ten A'lternatives - RARE II Lands; USFS, 1978, RARE II DES, So. Appal. Suppl. 0i1 and Gas - Vlissides and Quirin, 1963, 0il and Gas Fields of the U.S.; Cardwe11, 1971, AAPG Mem. 15; USGS, 1974 and 1975, Maps of Appal..0i1 and Gas Production; Miller and Others, 1975, USGS Circ. 725; Harris and Milici, 1977, USGS Prof. Paper 1018; Patchen and 0thers, 1978, AAPG Bul1. 8. Uranium -- ERDN, 1976, NURE Prel iminary Report. Coa1 Trumbu11, 1960, Coal Fields of the U.S. Geothermal - AAPG, 1976a and b, Geothermal Gradient Map and Subsurf. Temp. Map of N. Am. Critical Minerals - Lesure, 1957, V.P.I. BuT1., Eng. Expt. Sta. series 118; Worl and Others, 1968, F1uorite Deposits of the U.S.; Lesure and Others, 1978, U.S.G.S. Bull. $1397 c$. 
ENERGY AND MINERAL RESOURCE EVALUATION - RARE II TRACTS

TRACT N0: 08186

NATIONAL FOREST: Jefferson

ACREAGE (GROSS): 4,000 ACREAGE (NET): 3,870
TRACT NAME: Mill Creek WSA

ECOREG: 2214

WAR: 17

STATE/COUNTY: Virginia, Giles

$100 \mathrm{~N} / \mathrm{G}: 96.8$ LATITUDE: $37^{\circ} 17^{\prime}$ LONGITUDE: $80^{\circ} 48^{\prime}$

INDIVIDUAL TRACT

RESOURCE RATINGS

$\begin{array}{ccc}\text { ORNL } & & \text { USFS } \\ 3 / 1 & & 1 \\ 2 / 1 & 1 \\ 1 / 4 & 1 \\ 2 / 1 & 1 \\ 3 / 3 & 4 \\ 2 & \end{array}$

$\underline{\text { USGS }}$

REMARKS

OIL AND GAS

\section{1}

URANIUM

COAL

GEOTHERMAL

1

CRITICAL MINERALS

4

OVERALL RATING

(WEIGHTED)

Manganese mined in past; iron prospects

Crossed by high-tension line

NAMES OF CRITICAL MINERALS PRESENT: Possilbe iron, zinc, manganese, and lead; possible zinc, lead, cadmium, fluorite, and barite at depth

COMMENTARY AND SUMMARY: This tract is in the thrust fault-dominated part of the Valley and Ridge provincc. The rocks are quite favorable for oil and gas. Sandstone units may be favorable for uranium. The rocks are too old for coal. Hot dry rock at depth may be favorable as a source of geothermal energy. Crticial minerals for which the surface rocks are favorable include zinc, manganese, and lead (weathered Devonian Oriskany Sandstone) and iron (Devonian Helderberg Limestone and Silurian clinton Formation). Ordovician carbonates at depth may contain zinc, lead, cadmium, barite, and fluorite. Manganese has been mined in the area, and thère aré prospejects for iron in the tract. txcépt for iron, manganese, oil, and gas, little exploration has been performed for resources in the immediate area.

GEOLOGY: Surface rocks are Upper Ordovician to Lower Devonian shales and sandstones synclinally folded.

REFERENCE/CITATION: All resources - Milici and 0thers, 1963, Geol. Map of Va.; Gooch and Pharr, 1959, Mineral Indus. and Res. of Va.; USGS and USBM, 1968, USGS Prof. Paper 580; Miller and Others, 1970, Mineral Res. of the TVA Region; Brobst and Pratt, 1973, USGS Prof. Paper 820; D0E, 1978, Energy Res. Assessments of RARE II Lands; DOE, 1978, Energy Res. Assessments of Ten Alternatives - RARE II Lands; USFS, 1978, RARE II DES, So. Appa1. Suppl. $0 i 1$ and Gas - V1 issides and Quirin, 1963, $0 i 1$ and Gas Fields of the U.S.; Cardwel1, 1971, AAFG Mem. T5; USGS, 1974 and 1975, Maps of Appal. 0i1 and Cas Production; Miller and Others, 1975, USGS Circ. 725; Harris and Milici, 1977, USGS Prof. Paper 1018; Patchen and Others, 1978, AAPG Bu11. 8. Uranium - ERDA, 1976, NURE Preliminary Report. Coa] Trumbul1, 1960, Coal Fields of the U.S. Geothermal - AAPG, 1976a and b, Geothermal Gradient Map and Subsurf. Temp. Map of N. Am. Critical Minerals-Lesure, 1957, V.P.I. Bull., Eng. Expt. Sta. series 118; Worl and Others, 1968, Fluorite Deposits of the U.S.; Lesure and Others, 1978, U.S.G.S. Bu11. $1397 \mathrm{c}$. 
NATIONAL FOREST: Jefferson

ACREAGE (GROSS): 11,827 ACREAGE (NET): 10,228

INDIVIDUAL TRACT

RESOURCE RATINGS

ORNL

$$
\underline{\text { USFS }} \quad \underline{\text { DOE }} \quad \underline{\text { USGS }}
$$

OIL AND GAS

$3 / 2$

$2 / 1$

URANIUM

COAL

GEOTHERMAL

CRITICAL MINERALS

$1 / 4$

$2 / 1$

$3 / 2$

4
STATE/COUNTY: Virginia/West Virginia, Giles/Craig/Monroe

OVERALL RATING

(WEIGHTED)

$3^{-}$

NAMES OF CRITICAL MINERALS PRESENT: Possible zinc, iron, manganese, lead, cadmium, fluorite, and barite

COMMENTARY AND SUMMARY: This tract is in the thrust fault-dominated part of the Valley and Ridge province. The rocks are quite favorable for $0 i 1$ and gas. Sandstone units may be favorable for uranium. The rocks are too old for coal. Hot dry rock at depth may be favorable as a source of geothermal energy. Critical minerals for which the surface rocks are favorable include zinc, manganese, and lead (weathered Devonian Oriskany Sandstone); iron (Devonian Helderberg Limestone and Silurian Clinton Formation); and zinc, lead, cadmium, barite, and fluorite (Ordovician carbonates). Except for oil and gas, little exploration has occurred for resources in the area.

GEOLOGY: Surface rocks are Ordovician to Middle Devonian limestones, shales, and sandstones anticlinally and synclinally folded and faulted.

REFERENCE/CITATION: All resources - Milici and Others, 1963, Geol. Map of Va.; Gooch and Pharr, 1959, Mineral Indus. and ReS. of Va.; USGS and USBM, 1968, USGS Prof. Paper 580; Mi.jier and 0thers, 1970, Mineral Res. of the TVA Region; Brobst and Pratt, 1973, USGS Prof. Paper 820; D0E, 1978, Energy Res. Assessments of RARE II Lands; DOE, 1978, Energy Res. Assessments of Ten Alternatives - RARE II Lands; USFS, 1978, RARE II DES, So. Appa7. Suppl. $0 i 1$ and Gas - Vlissides and Quirin, 1963, $0 i 1$ and Gas Fields of the U.S.; Cardwel1, 1971, AAPG Mem. 15; USGS, 1974 and 1975, Maps of Appal. 0i1 and Gas Production; Miller and Others, 1975, USGS Circ. 725; Harris and Milici, 1977, USGS Prof. Paper 1018; Patchen and Others, 1978, AAPG Bul1. 8. Uranium - ERDA, 1976, NURE Prel iminary Report. CoalTrumbul1, 1960, Coal Fields of the U.S. Geothermal - AAPG, 1976a and b, Geothermal Gradient Map and Subsurf. Temp. Map of N. Am. Critical Minerals-Lesure, 1957, V.P.I. Bul1., Eng. Expt. Sta. series - 118; Worl and 0thers, 1968, Fluorite Deposits of the U.S.; l.esure and 0thers, 1978, U.S.G.S. Bull. $1397 c$. 
TRACT NO: 08188

NATIONAL FOREST: Jefferson

ACREAGE (GROSS): 4,183

TRACT NAME: Peters Mountain WSA

ECOREG : 2214

WAR: 19

STATE/COUNTY: Virginia/West Virginia, Giles/Monroe

ACREAGE (NET): 4,058

$100 \mathrm{~N} / \mathrm{G}: 97 \quad$ LATITUDE: $37^{\circ} 25^{\prime}$

LONGITUDE : $80^{\circ} 38^{\prime}$

INCIVIDUAL TRACT RESUUURLE RATINGS $\underline{\text { ORNL }}$

USFS DOE

Usas RCMARKS

OIL AND GAS

$$
3 / 2
$$

1

URANIUM

$2 / 7$

1

COAL

GEOTHERMAL

$1 / 4$

1

CRITICAL MINERALS

$2 / 1$

1

$3 / 2 \quad 4$

OVERALL RATINṬT

(WEIGHTED)

NAMES OF CRITICAL MINERALS PRESENT: Possible zinc, manganese, iron, and lead; possible zinc, lead, cadmium, barite, and fluorite at depth

COMMENTARY AND SUMMARY: This tract is in the thrust fault-dominated part of the Valley and Ridge province. The rocks are quite favorable for oill and gas. Sandstone units may be favorable for uranium. The rocks are too old for coal. Hot dry rock at depth may be favorable as a source of geothermal energy. Critical minerals for which the surface rocks are favorable include zinc, manganese, and lead (Üevonian Oriskany Sandstone) and Iron (Uevonian Helderberg Liméstöié ánd S1lurian Clinton Formation). Ordovician carbonates at depth may contain zinc, lead, cadmium, barite, and fluorite. Little exploration has occurred for resources in the area except for oil and gas.

GEOLOGY: Surface rocks are Silurian to Middle Devonian shales and sandstones synclinally folded and faulted.

REFERENCE/CITATION: All resources - Milici and Others, 1963, Geol. Map of Va.; Gooch and Pharr, 1959, Mineral Indus. and Res. of Va.; USGS and USBM, 1968, USGS Prof. Paper 580; Miller and 0thers, 1970, Mineral Res. of the TVA Region; Brobst and Pratt, 1973, USGS Prof. Paper 820; D0E, 1978, Energy Res. Assessments of RARE II Lands; DOE, 1978, Energy Res. Assessments of Ten Alternatives - RARE II Lands; USFS, 1978, RARE II DES, So. Appa1. Supp1. 0i1 and Gas - V1issides and Quirin, 1963, 0il and Gas Fields of the U.S.; Cardwe11, 1971, AAPG Mem. 15; USGS, 1974 and 1975, Maps of Appal. 0i1 and Gas Production; Miller and Others, 1975, USGS Circ. 725; Harris and Milici, 19/7, USGS Prof. Paper 1018; Patchen and 0thers, 1978, AAPG Bu11. 8. Uranium - ERDA, 1976, NURE Preliminary Report. Coal Trumbu11, 1960, Coal Fieids of the U.S. Geothermal - AAPG, 1976a and b, Geothermal Gradient Map and Subsurf. Temp. Map of N. Am. Critical Minerals-Lesure, 1957, V.P.I. Bu11., Eng. Expt. Sta. series 118; Worl and Others, 1968, Fluorite Deposits of the U.S.; Lesure and Others, 1978, U.S.G.S. Bull. $1397 \mathrm{c}$. 
ENERGY AND MINERAL RESOURCE EVALUATION - RARE II TRACTS

TRACT NO: 08193

TRACT NAME: Craggy Mountain WSA

ECOREG : 2214

WAR: 15

NATIONAL FOREST: Pisgah

STATE/COUNTY: North Carolina, Bumcombe

ACREAGE (GROSS): 1,100 ACREAGE (NET): $1,100 \quad 100 \mathrm{~N} / \mathrm{G}: 100 \quad$ LATITUDE: $35^{\circ} 43^{\prime} \quad$ LONGITUDE: $82^{\circ} 23^{\prime}$.

INDIVIDUAL TRACT

RESOURCE RATINGS

ORNL

$\underline{\text { USFS }} \quad \underline{\text { DOE }}$

$\underline{\text { USGS }}$

REMARKS

$\begin{array}{lcc}\text { OIL AND GAS } & 2 / 1 & 1 \\ \text { URANIUM } & 2 / 2 & 1 \\ \text { COAL } & 1 / 4 & 1 \\ \text { GEOTHERMAL } & 2 / 1 & 1 \\ \begin{array}{l}\text { CRITICAL MINERALS } \\ \begin{array}{l}\text { OVERALL RATING } \\ \text { (WEIGHTED) }\end{array}\end{array} & 3 / 1 & 1 \\ \end{array}$

Within NURE favorable area (ERDA 1976)

and associated with pegmatites

NAMES OF CRITICAL MINERALS PRESENT: POSSibIe mica

COMMENTARY AND SUMMARY: This tract is in the Blue Ridge province. The rocks below the basal Blue Ridge Thrust may be favorable for gas (Harris 1976). Pegmatites are favorable for uranium (ERDA 1976). The rocks are too old for coal. Hot dry rock at depth may be favorable as a source of geothermal energy. The tract is quite favorable for mica because it lies within a broad northeast-trending region known for pegmatites and associated mica deposits. Little exploration has occurred for any resources in the immediate area.

GEOLOGY: Chiefly mica gneiss and mica schist of Precambrian age.

RCICRENGE/CITATION: All rosources - N,r. Dept. Conserv. and Develop., Div. Min. Res., 1959, Geol. Map of N.C.; USGS and USBM, 1968, USGS Prof. Paper 580; Miller and Others, 1970, Mineral Res. of the TVA Region; Bryant and Reed, 1970, USGS Prof. Paper 615; Brobst and Pratt, 1973, USGS Prof. Paper 820; DOE, 1978, Energy Res. Assessments of RARE II Lands; DOE, 1978, Energy Res. Assessments of Ten Alternatives - RARE II Lands; USFS, 1978, RARE II DES, So. Appal. Suppl. 0il and Gas - Vlissides and Quirin, 1963, 0il and Gas Fields of the U.S.; Cardwel1, 1971, AAPG Mem. 15; USGS, 1974 and 1975, Maps of Appal. 0il and Gas Production; Miller and Others, 1975, USGS Circ. 725; Harris and Milici, 1977, USGS Prof. Paper 1018; Patchen and Others, 1978, AAPG Bu11. 8. Uranium - Bryant and Reed, 1966, USGS Circ. 521; ERDA, 1976, NURE Preliminary Report. Coal - Trumbu11, 1960, Coal Fields of the U.S. Geothermal - AAPG, 1976a and D, Geothermal Gradient Map and Subsurface Temperature Map of North America. Critical Minerals - Lesure, 1968, USGS Prof. Paper 577; Orie1, 1950, N.C. Dept. Conserv. and Devel., Div. Min. Res., Bull. 60. 
TRACT NO: 08197

NATIONAL FOREST: Pisgah

ACREAGE (GROSS): 7,120
TRACT NAME: Wildcat

\author{
STATE/COUNTY: North Carolina, Madison
}

ACREAGE (NET): 7,120
$100 \mathrm{~N} / \mathrm{G}:{ }^{\prime} 100$ LATITUDE: $34^{\circ} 46^{\prime}$ LONGITUDE: $83^{\circ} 02^{\prime}$
INDIVIDUAL TRACT

RESOURCE RATINGS

OIL AND GAS

IIRANTIIM

COAL

GEOTHERMAL

CRITICAL MINERALS

OVERALL RATING

(WEIGHTED) $\underline{\text { ORNL }} \quad \underline{\text { USFS }} \quad \underline{\text { DOE }} \quad \underline{\text { USGS }}$

2

1

$2 / 1 \quad 1$

$3 / 2$

1

NAMES OF CRITICAL MINERALS PRESENT: Possible zirconium, titanium, and barium

COMMENTARY AND SUMMARY: This tract is in the Blue Ridge province. The rocks at depth below the basal Blue Ridge Thrust may be favorable for gas (Harris 1976). The tract is in an area favorable for uranium (ERDA 1976). The rocks are too old for coal. Hot dry rock at depth may be favorable as a source of geothermal energy. Finds of the critical mineral barite have been reported, and paleoplacers of titanium and ziconium may be located on the tract (USGS and USBM 1968). Little exploration has occurred in the immediate area for any resources except critical minerals.

GEOLOGY: Surface rocks are chiefly the Precambrian/Cambrian metasedimentary Ocoee Series and Cambrian Unicoi formation and, in the southern part of the tract, the Cranberry granite gneiss.

REFERENCE/CITATION: A11 resources - N.C. Dept. Conserv. and Develop., Div. Min. Res., 1959, Geol. Map of N.C..; USGS and USBM, 1968, USGS Prof. Paper 580; Miller and Others, 1970, Mineral Res. of the TVA Region; Bryant and Reed, 1970, USGS Prof. Paper 615; Brobst and Pratt, 1973, USGS Prof. Paper 820; DOE, 1978, Energy Res. Assessments of RARE II Lands; DOE, 1978, Energy Res. Assessments of Ten Alternatives - RARE II Lands; USFS, 1978, RARE II DES, So. Appal. Suppl. 0il and Gas - V1 issides and Quirin, 1963, 0il and Gas Fields of the U.S.; Cardwe11, 1971, AAPG Mem. 15; USGS, 1974 and 1975, Maps of Appal. 0il and Gas Production; Miller and Others, 1975, USGS Circ. 725; Harris and Milici, 1977, USGS Prof. Paper 1018; Patchen and 0thers, 1978, AAPG Bul1. 8. Uranium - Bryant and Reed, 1966, USGS Circ. 521; ERDA, 1976, NURE Preliminary Report. Coal - Trumbul1, 1960, Coal Fields of the U.S. Geothermal - AAPG, 1976a and b, Geothermal Gradient Map and Subsurface Temperature Map of North America. Critical Minerals - Lesure, 1968, USGS Prof. Paper 577; Orie1, 195U, N.Ć. Dept. Conserv. and Devel., Div. Min. Res., Bul1. 60. 
ENERGY AND MINERAL RESOURCE EVALUATION - RARE II TRACTS

TRACT NO: 08200

TRACT NAME: Middle Prong

ECOREG: $2214 \quad$ WAR: 20

NATIONAL FOREST: Pisgah

STATE/COUNTY: North Carolina, Haywood

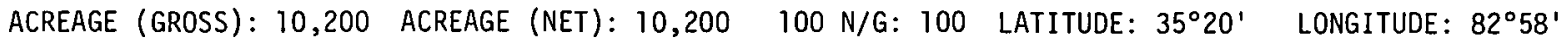

INDIVIDUAL TRACT

RESOURCE RATINGS

$\underline{\text { ORNL }} \underline{\text { USFS }} \quad \underline{D O E} \quad \underline{\text { USGS }}$

REMARKS

OIL AND GAS

$2 / 1 \quad 1$

URANIUM

$3 / 2 \quad 1$

Within NURE favorable area

(ERDA 1976)

COAL

$1 / 4 \quad 1$

GEOTHERMAL

$2 / 1 \quad 1$

Possible hot dry rock at depth

CRITICAL MINERALS

$3 / 3$

1

Franklin-Sylva Mica District (Lesure 1968)

OVERALL RATING

(WEIGHTED)

$3^{-}$

NAMES OF CRITICAL MINERALS PRESENT: Possible mica, gold, and silver

COMMENTARY AND SUMMARY: This tract is in the Blue Ridge province. The rocks below the basal Blue Ridge Thrust may be favorable for gas (Harris 1976). Pegmatite veins are favorable for uranium (ERDA 1976). The rocks are too old for coal. Hot dry rock at depth may be favorable as a source of geothermal energy. The tract is along the outer part of the Franklin-Sylva Mica District (Lesure 1968), and mica prospects in pegmatites are located on the tract. Gold and silver also may be present in the pegmatites. Except for critical minerals, little exploration has occurred in the immediate area.

GEOLOGY: Surface rocks are gneiss, schist, and irregular pegmetites at probable Precambrian age.

REFERENCE/CITATION: A11 resources - N.C. Dept. Conserv. and Develop., Div. Min. Res., 1959, Geol. Map of N.C.; USGS and USBM, 1968, USGS Prof. Paper 580; Miller and Others, 1970, Mineral Res. of the TVA Region: Bryant and Reed, 1970, USGS Prof. Paper 615: Brobst and Pratt, 1973, USGS Prof. Paper 820; DOE, 1978, Energy Res. Assessments of RARE II Lands; DOE, 1978, Energy Res. Assessments of Ten Alternatives - RARE II Lands; USFS, 1978, RARE II DES, So. Appal. Suppl. 0il and Gas - Vlissides and Quirin, 1963, 011 and Gas Fields of the U.S.; Cardwe11, 1971, AAPG Mem. 15; USGS, 1974 and 1975, Maps of Appal. Oil and Gas Production; Miller and Others, 1975, USGS Circ. 725; Harris and Milici, 1977, USGS Prof. Paper 1018; Patchen and 0thers, 1978, AAPG Bul1. 8. Uranium - Bryant and Reed, 1966, USGS Circ. 521; ERDA, 1976, NIJRF. Preliminary Report. Coal - Trumbul1, 1960, Coal Fields of the U.S. Geotherma I - AAPG, 1976a and b, Geothermal Gradient Map and Subsurface Temperature Map of North America. Critical Minerals - Lesure, 1968, USGS Prof. Paper 577; Oriel, 1950, N.C. Dept. Conserv. and Devel., Div. Mirl. Res., Bul1. 60. 
ENERGY AND MINERAL RESOURCE EVALUATION - RARE II TRACTS

TRACT NO: 08202

TRACT NAME: Nol ichucky

ECOREG: $2214 \quad$ WAR: 14

NATIONAL FOREST: Cherokee and Pisgah

STATE/COUNTY: Tennessee/North Carolina, Unicoi/Mitchell

ACREAGE (GROSS): 7,220 ACREAGE (NET): $7,020 \quad 100 \mathrm{~N} / \mathrm{G}: 97.2$ LATITUDE: $36^{\circ} 06^{\prime}$ LONGITUDE: $82^{\circ} 24^{\prime}$

INDIVIDUAL TRACT RESOURCE RATINGS

ORNL USFS DOE USCS

REMARKS

\begin{tabular}{|c|c|c|c|}
\hline OIL AND GAS & $2 / 1$ & 1 & \\
\hline URANIUM & $2 / 2$ & 1 & Within NURE favorable area (ERUA $19 / 6$ ) \\
\hline COAL & $1 / 4$ & 1 & \\
\hline GEOTHERMAL & $2 / 1$ & 1 & \\
\hline CRITICAL MINERALS & $3 / 2$ & 1 & Possible shady residuum \\
\hline $\begin{array}{l}\text { OVERALL RATING } \\
\text { (WEIGHTED) }\end{array}$ & 2 & 2 & $\begin{array}{l}\text { Hydroelectric conflict identified by DOE } \\
(1978)\end{array}$ \\
\hline
\end{tabular}

NAMES OF CRITICAL MINERALS PRESENT: Possible iron, manganese, zinc, lead, and barite

COMMENTARY AND SUMMARY: This tract is in the Blue Ridge province. The rocks at depth bclow the basal Blue Ridge Thrust may be favorable for gas (Harris 1976). The tract is within an area classified as favorable for uranium by NURE (ERDA 1976). The rocks are too old for coal. Hot dry rock at depth may be favorable as a source of geothermal energ.y. Iron, manganese, zinc, lead, and barite may exist in unmapped residuum of Shady Dolomite (King and Ferguson 1960), but the unit has been completely eroded from the tract. Little exploration for any resources has occurred except for critical minerals in the immertiat.e area.

GEOLOGY: Surface rocks are the Precambrian Cranberry Gneiss and the Lower Cambrian shales and sandstones of the Unicoi, Hampton, and Erwin formations.

REFERENCE/CITATION: A11 resources - Hardeman and Others, 1966, Geol. Map of Tenn.; USGS and USBM, 1968, USGS Prof. Paper 580; Miller and Others, 1970, Mineral Res. of the TVA Region; Brobst and Pratt, 1973, USGS Prof. Paper 820; DOE, 1978, Energy Res. Assessments of RARE II Lands; DOE, 1978, Energy Res. Assessments of Ten Alternatives - RARE II Lands; USFS, 1978, RARE II DES, So: Appal. Suppl. 0il and Gas - V1issides and Quirin, 1963, 0il and Gas Fields of the U.S.; Cardwe11, 1971, AAPG Mem. 15; USGS, 1974 and 1975, Maps of Appal. 0 il and Gas Production; Miller and Others, 1975, USGS Circ. 725; Harris, 1976, J. Res. USGS, v. 4, no. 4; Harris and Milici, 1977, USGS Prof. Paper 1018; Van Den Berg and 0thers, 1978, AAPG Bu11. 62: 1340-5b. Uranium - tRUA, 19\%, NURE Preliminary Report. Coal - Irumbuil, ig6U, Coal Fields of the U.S. Geothermal - AAPG, 1976a and b, Geotherma' Gradient Map and Subsurface lemperature Map of North Am. Critical Minerals - King and Ferguson, 1960, USGS Prof. Paper 311. 
ENERGY AND MINERAL RESOURCE EVALUATION - RARE II TRACTS

TRACT NO: 08271

NATIONAL FOREST: Cherokee

ACREAGE (GROSS): 4,500
TRACT NAME: Hickory Flat Branch

ACREAGE (NET) : 4,500

\begin{tabular}{|c|c|}
\hline $\begin{array}{l}\text { INDIVIDUAL TRACT } \\
\text { RESOURCE RATINGS } \\
\end{array}$ & $\underline{\text { ORNL }}$ \\
\hline OIL AND GAS & $3 / 1$ \\
\hline URANIUM & $2 / 1$ \\
\hline COAL & $1 / 4$ \\
\hline GEOTHERMAL & $2 / 1$ \\
\hline CRITICAL MINERALS & $4 / 4$ \\
\hline $\begin{array}{l}\text { OVERALL RATING } \\
\text { (WE IGHTED) }\end{array}$ & $\cdot 3$ \\
\hline
\end{tabular}

STATE/COUNTY: Tennessee, Johnson/Carter

$100 \mathrm{~N} / \mathrm{G}: 100$ LATITUDE: $36^{\circ} 26^{\prime}$ LONGITUDE: $81^{\circ} 58^{\prime}$

ECOREG: $2214 \quad$ WAR: 18 .

NAMES OF CRITICAL MINERALS PRESENT: Manganese and iron; possible zinc, lead, and barite

COMMENTARY AND SUMMARY: This tract is in the Blue Ridge province. The rocks may be favorable for gas at depth below the basal Blue Ridge Thrust (Harris 1976). Sandstone and conglomerate units may be favorable for uranium. The rocks are too old for coal. Hot dry rock at depth may be favorable as a source of geothermal energy. The weathered Shady Dolomite contains mined deposits of manganese and iron ore and is quite favorable for zinc, lead, and barite (King and Ferguson 1960). Except for critical minerals, little exploration for resources has occurred.

GEOLOGY: Surface rocks are Lower Cambrian shales, sandstones, and carbonates of the Unicoi, Hampton, Erwin, and Shady formations, on the southeastern flank of the Stony Creek syncline, which is cut by the Cross Mountain Fault.

REFERENCE/CITATION. A11 resources - Hardeman and 0thers, 1966, Geol. Map of Tenn.; USGS and USBM, 1968, USGS Prof. Paper 580; Miller and 0thers, 1970, Mineral Res. of the TVA Region; Brobst and Pratt, 1973, USGS Prof. Paper 820; DOE, 1978, Energy Res. Assessments of RARE II Lands; DOE, 1978, Energy Res. Assessments of Ten Alternatives - RARE II Lands; USFS, 1978, RARE II DES, So:. Appal. Suppl. 0il and Gas - Vlissides and Quirin, 1963, 0il and Gas Fields of the U.S.; Cardwe11, 1971, AAPG Mem. 15; USGS, 1974 and 1975, Maps of Appal. 0i1 and Gas Production; Miller and Others, 1975, USGS Circ. 725; Harris, 1976, J. Res. USGS, v. 4, no. 4; Harris and Milici, 1977, USGS Prof. Paper 1018; Van Den Berg and 0thers, 1978, AAPG Bul1. 62: 1340-55. Uranium - ERDA, 1976, NURE Preliminary Report. Coal - Trumbu11, 1960, Coal Fields of the U.S. Geothermal-AAPG, 1976a and b, Geothermal Gradient Map and Subsurface Temperature Map of North Am. Critical Minerals - King and Ferguson, 1960, USGS Prof. Paper 311. 
ENERGY AND MINERAL RESOURCE EVALUATION - RARE II TRACTS

TRACT NO: 08272

TRACT NAME: Big Laurel Branch

ECOREG : 2214

WAR: 13

NATIONAL FOREST: Cherokee

STATE/COUNTY: Tennessee, Carter

ACREAGE (GROSS): 6,000 ACREAGE (NET): $6,000 \quad 100 \mathrm{~N} / \mathrm{G}: 100$ LATITUDE: $36^{\circ} 22^{\prime} \quad$ LONGITUDE: $82^{\circ} 04^{\prime}$

INDIVIDUAL TRACT

RESOURCE RATINGS

$\underline{\text { ORNL USFS }}$ DOE USGS

REMARKS

OIL AND GAS

$3 / 1 \quad 1$

IIRANIUM

$2 / 1$

1

1

COAL

$1 / 4 \quad 1$

1

GEOTHERMAL

$2 / 1 \quad 1$

CRITICAL MINERALS $\quad \cdot 4 / 4 \quad 1$

OVERALL RATING

(WEIGHTEN)

1 $34^{\star}$

\author{
Shady Valley Manganese District (King and \\ Terguson 1060) \\ Based on existing Wilbur Dam hydroelectric \\ facilities (DUE $1 \mathrm{y} / \mathrm{8}$ )
}

NAMES OF CRITICÁL MINERALS PRESENT: Manganese and iron; possible zinc, lead, and barite

COMMENTARY AND SUMMARY: This tract is in the Blue Ridge province. The rocks may be favorable for gas at depth below the basal Blue Ridge Thrust (Harris 1976). Sandstone and conglomerate units may be favorable for uranium. The rocks are too old for cual. Hot dry rock at depth may be favorable as a source of geothermal energy. The weathered Shady Dolomite contains mined deposits of manganese and iron ore and is quite favorable for zinc, lead, and barite (King and Ferguson 1960). Except for critical minerals, little exploracion for resuurces has occurred.

GEOLOGY: Surface rocks are Lower Cambrian shales, sandstones, and carbonates of the Unicoi, Hampton, Erwin, and Shady formations on the southeastern flank of the Stony Creek Valley Syncline.

REFERENCE/CITATION: A11 resources - Hardeman and Others, 1966, Geol. Map of Tenn.; USGS and USBM, 1968, USGS Prof. Paper 580; Miller and 0thers, 1970, Mineral Res. of the TVA Region; Brobst and Pratt, 1973, USGS Prof. Paper 820; DOE, 1978, Energy Res. Assessments of RARE II Lands; D0E, 1978, Energy Res. Assessments of Ten Alternatives - RARE II Lands; USFS, 1978, RARE II DES, So. Appa 1. Supp1. 0i1 and Gas - V1issides and Quirin, 1963, 0il and Gas Fields of the U.S.; Cardwe11, 1971, AAPG Mem. 15; USGS, $\overline{1974}$ and 1975, Maps of Appal. Oil and Gas Production; Miller and Others, 1975, USGS Circ. 725; Harris, 1976, J. Res. USGS, v. 4, no. 4; Harris and Milici, 1977, USGS Prof. Paper 1018; Van Den Berg and 0thers, 1978, MPG Bu11. 62: 1340-55. IIranium - ERDA, 1976. NURE Prel iminary Report. Coal - Trumbu11, 1960, Coal Fields of the U.S. Geotherma -AAPG, $197 \mathrm{ba}$ and b, Geothermal Gradienil Map and subsuritace Temperature Map of North Am. Critical Miñerals - King and Ferguson, 1960, USGS Prof. Paper 311. 
ENERGY AND MINERAL RESOURCE EVALUATION - RARE II TRACTS

TRACT NO: 08273

NATIONAL FOREST: Cherokee

ACREAGE (GROSS): 2,300
TRACT NAME: Pond Mountain Addition

ECOREG: 2214

WAR: 13

STATE/COUNTY: Tennessee, Carter

ACREAGE (NET): 2,300

$100 \mathrm{~N} / \mathrm{G}: 100$ LATITUDE: $36^{\circ} 18^{\prime}$

LONGITUDE: $82^{\circ} 05^{\prime}$

\begin{tabular}{|c|c|}
\hline $\begin{array}{l}\text { INDIVIDUAL TRACT } \\
\text { RESOURCE RATINGS } \\
\end{array}$ & ORNL \\
\hline OIL AND GAS & $2 / 1$ \\
\hline URANIUM & $3 / 2$ \\
\hline COAL & $1 / 4$ \\
\hline GEOTHERMAL & $2 / 1$ \\
\hline CRITICAL MINERALS & $3 / 2$ \\
\hline $\begin{array}{l}\text { OVERALL RATING } \\
\text { (WEIGHTED) }\end{array}$ & $3-$ \\
\hline
\end{tabular}

DOE USGS

NAMES OF CRITICAL MINERALS PRESENT: Possible iron, manganese, zinc, lead, barite, zirconium, thorium, and rare earths

COMMENTARY AND SUMMARY: This tract is in the Blue Ridge. Possible sedimentary rocks below the basal Blue Ridge Thrust may be favorable for gas (Harris 1976). The Precambrian granite rocks are within the Walnut Mountain Uranium District (USSGS and USBM 1968) and with in one of the NURE favorable areas (ERDA 1976). The rocks are too old for coal. Hot dry rock at depth may be favorable as a source of geothermal energy. The weathered Shady Dolomite is quite favorable for iron, manganese, zinc, lead, and barite, and the granites may contain zirconium, thorium, and rare earths (King and Ferguson 1960 and USGS and USBM 1968). Except for uranium and critical minerals, little exploration for resources in the immediate area has occurred.

GEOLOGY: Surface rocks are Precambrian granitic rocks and Lower Cambrian shales, sandstones, and carbonates of the Unicoi through Shady formations in the Doe River Cove Window.

REFERENCE/CITATION: A11 resources - Hardeman and 0thers, 1966, Geo1. Map of .Tenn.; USGS and USBM, 1968, USGS Prof. Paper 580; Miller and 0thers, 1970, Mineral Res. of the TVA Region; Brobst and Pratt, 1973; USGS Prof. Paper 820; DOE, 1978, Energy Res. Assessments of RARE II Lands; DOE; 1978, Energy Res. Assessments of Ten Alternatives - RARE II Lands; USFS, 1978, RARE II DES, So. Appal. Suppl. 0il and Gas - VIissides and Quirin, 1963, 0il and Gas Fields of the U.S.; Cardwe11, 1971, AAPG Mem. 15; USGS, $\overline{1974}$ and 1975, Maps of Appal. Oil and Gas Production; Miller and Others, 1975, USGS Circ. 725; Harris, 1976, I. Res. USGS, v. 4, no. 4; Harris and Milici, 1977, USGS Prof. Paper 1018; Van Den Berg and 0thers, 1978, AAPG Bu11. 62: 1340-55. Uranium - ERDA, 1976, NURE Prel iminary Report. Coá1 - Trumbu11, 1960, Coal Fields of the U.S. Geothermal-AAPG, 1976a and b, Geothermal Gradient Map and Subsurface Temperature Map of North Am. Critical Minerals - King and Ferguson, 1960, USGS Prof. Paper 311. 
ENERGY AND MINERAL RESOURCE EVALUATION - RARE II TRACTS

TRACT N0: 08274

NATIONAL FOREST: Cherokee

ACREAGE (GROSS): 2,200 ACREAGE (NET): 2,200
TRACT NAME: Laure] Fork

STATE/COUNTY: Tennessee, Carter

$100 \mathrm{~N} / \mathrm{G}: 100$ LATITUDE: $36^{\circ} 15^{\prime} \quad$ LONGITUDE : $82^{\circ} 05^{\prime}$

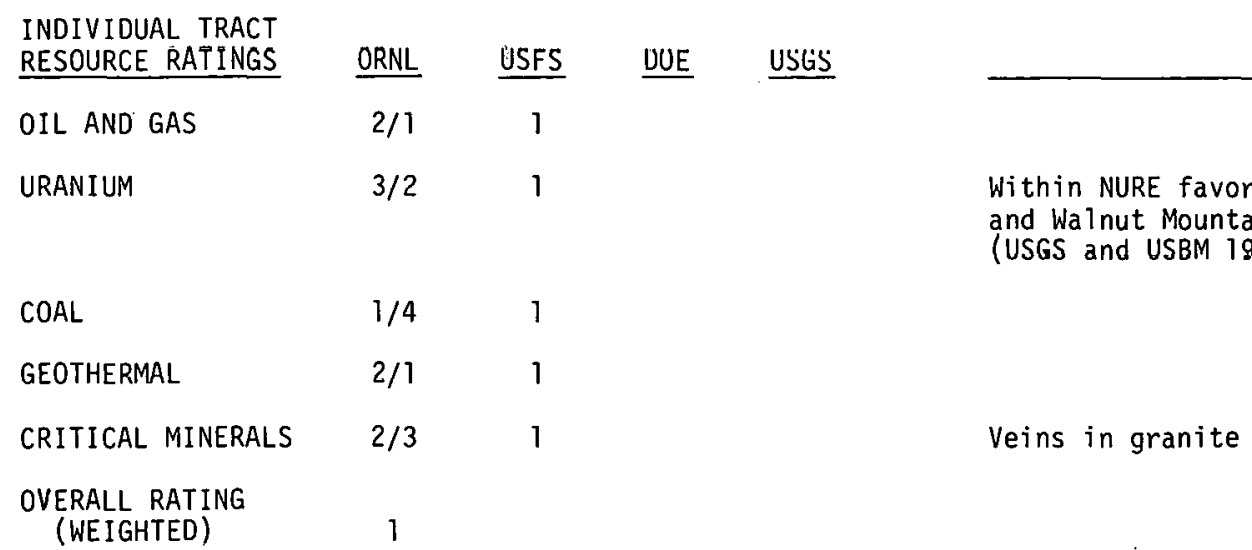

NAMES OF CRITICAL MINERALS PRESENT: Possible hematite, zirconium, thorium, and rare earths

COMMENTARY AND SUMMARY: This tract is in the Blue Ridge province. The rocks at depth below the basal Blue Ridge Thrust may be favorable for gas (Harris 1976). The tract is within the Walnut Mountain Uranium District (USGS and USBM 1968) and a NURE favorable area (ERDA 1976). The uranium occurs in veins in the granite. The rocks are too old for coal. Hot dry rock at depth may be favorable as a source of geothermal energy. Hematite, ziconium, thorium, and rare earths may occur in pegmatites (USGS 1968). Little expioration has occurred in the immediate area for any resources except uranium.

GEOLOGY: Surface rock is Precambrian Beech granite.

REFERENCE/CITATION: All resources - Hardeman and Others, 1966, Geol. Map of Tenn.; USGS and USBM, 1968, USGS Prof. Paper 580; MilTer and Others, 1970, Mineral Res. of the TVA Region; Brobst and Pratt, 1973, USGS Prof. Paper 820; DOE, 1978, Energy Res. Assessments of RARE II Lands; D0E, 1978, Energy Res. Assessments of Ten Alternatives - RARE II Lands; USFS, 1978, RARE II DES, So. Appal. Suppl. Oil and Gas - Vlissides and Quirin, 1963, 0i1 and Gas Fields of the U.S.; Cardwe11, 1971, AAPG Mem. 15; USGS, T974 and 1975, Maps of Appal. 0il and Gas Production; Miller and Others, 1975, USGS Circ. 725; Harris, 1976, J. Res. USGS, v. 4, no. 4; Harris and Milici, 1977, USGS Prof. Paper 1018; Van Den Berg and 0thers, 1978, AAPG Bu11. 62: 1340-55. Uranium - ERDA, 1976, NURE Preliminary Report. Coal - Trumbu11, 1960, Coal Fields of the U.S. Geothermal - AAPG, 1976a and $b$, Geothermal Gradient Map and Subsurface Temperature Map of North Am. Critical Minerals - King and Ferguson, 1960, USGS Prof. Paper 311. 
ENERGY AND MINERAL RESOURCE EVALUATION - RARE II TRACTS

TRACT NO: 08275

NATIONAL FOREST: Cherokee

ACREAGE (GROSS): 4,700 ACREAGE (NET): 4,700
TRACT NAME: Unaka Mountain

ECOREG: 2214

WAR: 16

STATE/COUNTY: Tennessee, Unicoi

$100 \mathrm{~N} / \mathrm{G}: 100$ LATITUDE: $36^{\circ} 09^{\prime}$ LONGITUDE: $82^{\circ} 18^{\prime}$

INDIVIDUAL TRACT

RESOURCE RATINGS

$\underline{O R N L} \quad \underline{\text { USFS }} \quad \underline{\mathrm{DOE}} \quad \underline{\mathrm{USGS}}$

REMARKS

OIL AND GAS

$2 / 1$

1

URANIUM

$2 / 2$

1

Within NURE favorable area

(ERDA 1976)

COAL

$1 / 4 \quad 1$

GEOTHERMAL

$2 / 1$

1

CRITICAL MINERALS

$2 / 2$

1

Possible Shady residuum

OVERALL RATING

(WEIGHTED)

$1^{+}$

NAMES OF CRITICAL MINERALS PRESENT: Possible iron, manganese, zinc, lead, and barite

COMMENTARY AND SUMMARY: This tract is in the Blue Ridge province. The rocks at depth below the basal Blue Ridge Thrust may be favorable for gas (Harris 1976). The tract is within an area classified as favorable for uranium by NURE (ERDA 1976). The rocks are too old for coal. Hot dry rock at depth may be favorable as a source of geothermal energy. Iron, manganese, zinc, lead, and barite may exist in unmapped residuum of Shady Dolomite (King and Ferguson 1960), but the unit has been completely eroded from the tract. Little exploration for any resources has occurred except for critical minerals in the immediate area.

GEOLOGY: Surface rocks are the Lower Cambrian shales and sandstones of the Unicoi-Erwin Formations.

REFERENCE/CITATION: All resources - Hardeman and Others, 1966, Geol. Map of Tenn.; USGS and USBM, 1968, USGS Prof. Paper 580; Miller and Ot.hers, 1970, Mineral Res. of the TVA Region; Brobst and Pratt, 1973, USGS Prof. Paper 820; DOE, 1978, Energy Res. Assessments of RARE II Lands; DOE, 1978, Energy Res. Assessments of Ten Alternatives - RARE II Lands; USFS, 1978, RARE II DES, So. Appal. Suppl. 0il and Gas - Vlissides and Quirin, 1963, 0il and Gas Fields of the U.S.; Cardwe11, 1971, AAPG Mem. 15; USGS, $\overline{1974}$ and 1975, Maps of Appa1. 0il and Gas Production; Miller and Others, 1975, USGS Circ. 725; Harris, 1976, J. Res. USGS, v. 4, no. 4; Harris and Milici, 1977, USGS Prof. Paper 1018; Van Den Berg and Others, 1978, AAPG Bu11. 62: 1340-55. Uranium - ERDA, 1976, NURE Prel iminary Report. Coal - Trumbu11, 1960, Coal Fields of the II.S. Geothermal - AAPG, 1976a and b, Geothermal Gradient Map and Subsurface Temperature Map of North Am. Critical Minerals - King and Ferguson, 1960, USGS Prof. Paper 311. 
TRACT NO: 08276

NATIONAL FOREST: Cherokee
TRACT NAME: Devil's Backbone

ECOREG: 2214

WAR: 16

\begin{tabular}{|c|c|c|c|c|c|}
\hline $\begin{array}{l}\text { INDIVIDUAL TRACT } \\
\text { RESOURCE RATINGS } \\
\end{array}$ & $\underline{\text { ORNL }}$ & $\underline{\text { USFS }}$ & $\underline{\mathrm{DOE}}$ & $\underline{\text { USGS }}$ & REMARKS \\
\hline OIL AND GAS & $2 / 1$ & 1 & & & \\
\hline URANIUM & $2 / 2$ & 1 & & & NURE favorable area (ERDA 1976) \\
\hline COAL & $1 / 4$ & 1 & & & \\
\hline GEOTHERMAL & $2 / 1$ & 1 & & & \\
\hline CRITICAL MINERALS & $3 / 2$ & 1 & & & Shady Dolomite (very little on tract) \\
\hline $\begin{array}{l}\text { OVERALL RATING } \\
\text { (WEIGHTED) }\end{array}$ & 2 & & & & \\
\hline
\end{tabular}

NAMES OF CRITICAL MINERALS PRESENT: Possible iron, manganese, zinc, lead, and barite

COMMENTARY AND SUMMARY: This tract is in the BTue Ridge province. The sedimentary rocks at depth below the basal Blue kidge lhrust may be favorable for gas (Harris 1976). The tract is in an area favorable for uranium (ERDA 1976). The rocks are too old for coal. Hot dry rock at depth may be favorable as a source of geothermal energy. The weathered Shady Dolomite contains mined deposits of manganese and prospects for iron and is quite favorable for zinc, lead, and barite (King and Ferguson 1960). For other resources, little exploration in the immediate area has occurred.

GEOLOGY: Surface rocks are the Lower Cambrian shales and sandstones of the. Erwin Formation and the Shady Dolomite.

REFERENCE/CITATION: A11 resources - Hardeman and 0thers, 1966, Geo1. Map of Tenn.; USGS and USBM, 1968, USGS Prof. Paper 580; Miller and Others, 1970, Mineral Res. of the TVA Region; Brobst and Pratt. 1973. USGS Prof. Paper 820; DOE, 1978, Energy Res. Assessments of RARE II Lands; D0E, 1978, Energy Res. Assessments of Ten Alternatives - RARE II Lands: USFS, 1978, RARE II DES, Sn. Appal. Suppl. Oi1 and Gas - Vlissides and Quirin, 1963, 011 and Gas Fields of the U.S.; Cardwe 11, 1971, AAPG Mem. 15; USGS, 1974 and 1975, Maps of Appal. Oil and Gas Production; Miller and Others, 1975, USGS Circ. 725; Harris, 1976, J. Res. USGS, v. 4, no. 4; Harris and Milici, 1977, USGS Prof. Paper 1018; Van Den Berg and 0thers, 1978, AAPG Bu11. 62: 1340-55. Uranium - ERDA, 1976, NURE Preliminary Report. Coal - Trumbu11, 1960, Coal Field's of the U.S. Geothermal - AAPG, 1976a and b, Geothermal Gradient Map and Subsurface Temperature Map of North Am. Critical Minerals - King and Ferguson, 1960, USGS Prof. Paper 311. 
ENERGY AND MINERAL RESOURCE EVALUATION - RARE II TRACTS

TRACT NO: L8313

NATIONAL FOREST: Pisgah

ACREAGE (GROSS): 6,590
TRACT NAME: Upper Wilson

ECOREG : 2214

WAR: 17

STATE/COUNTY: North Carolina, Caldwell

ACREAGE (NET): $6,530 \quad 100 \mathrm{~N} / \mathrm{G}: 99.1 \quad$ LATITUDE: $36^{\circ} 03^{\prime} \quad$ LONGITUDE: $81^{\circ} 48^{\prime}$
INDIVIDUAL TRACT

RESOURCE RATINGS

OIL AND.GAS

URANIUM

COAL

GEOTHERMAL

CRITICAL MINERALS

OVERALL RATING

(WEIGHTED)

\begin{tabular}{|c|c|}
\hline ORNL & USFS \\
\hline $2 / 1$ & 1 \\
\hline $4 / 2$ & 1 \\
\hline $1 / 4$ & 1 \\
\hline $2 / 1$ & 1 \\
\hline $2 / 1$ & 1 \\
\hline 3 & 1 \\
\hline
\end{tabular}

NAMES OF CRITICAL MINERALS PRESENT: Possible mica, feldspar, and rare earths

COMMENTARY AND SUMMARY: This tract is within the Grandfather Mountain Window of the Blue Ridge province. The rocks may be favorable for gas at depth below the basal Blue Ridge Thrust (Harris 1976). If the Brevard Zone nearby to the southeast is the root zone of the west-directed thrusting (Bryant and Reed 1970), the potential is very slight. Uranium has been reported as occurring on the tracts nearby (Bryant and Reed 1966). The rocks are too old for coal. Hot dry rock at depth may be favorable as a source of geothermal energy. Other than uranium, no critical minerals are known to occur in the tract, but mica, feldspar, rare earths, and others could occur in pegmatites in the gneiss. Little exploration has occurred in the immediate area for any resources except uranium, for which minor exploration has taken place.

GEOLOGY: Surface rock is Precambrian Wilson Creek Gneiss.

REFERENCE/CITATION: All resources - N.C. Dept. Conserv, and Develop., Div. Min. Res., 1959, Geol. Map of N.C.; USGS and USBM, 1968, USGS Prof. Paper 580; Miller and Others, 1970, Mineral Res. of the TVA Region; Bryant and Reed, 1970, USGS Prof. Paper 615; Brobst and Pratt, 1973, USGS Prof. Paper 820; DOE, 1978, Energy Res. Assessments of RARE II Lands; DOE, 1978, Energy Res. Assessments of Ten Alternatives - RARE II Lands; USFS, 1978, RARE II DES, So. Appal. Suppl. Oil and Gas - Vlissides and Quirin, 1963, 011 and Gas Fields of the U.S.; Cardwe11, 1971, AAPG Mem. 15; USGS, 1974 and 1975, Maps of Appal. 0il and Gas Production; Miller and 0thers, 1975, USGS Circ. 725; Harris and Milici, 1977, USGS Prof. Paper 1018; Patchen and 0thers, 1978, AAPG Bu11. 8. Uranium - Bryant and Reed, 1966, USGS Circ. 521; ERDA, 1976, NURE Preliminary Report. Coal - Trumbul1, 1960, Coal Fields of the U.S. Geothermal - AAPG, 1976a and b, Geothermal Gradient Map and Subsurface Temperature Map of North Americà. Critical Minerals - Lesure, 1968, USGS Prof. Paper 577; Orie1, 1950, N.C. Dept. Conserv. and Deve1., Div. Min. Res., Bul1. 60. 
ENERGY AND MINERAL RESOURCE EVALUATION - RARE II TRACTS

TRACT NO: $L 8314$

NATIONAL FOREST: Pisgah

ACREAGE (GROSS): 5,708
TRACT NAME: Lost Cove

STATE/COUNTY: North Carolina, Avery

ECOREG : 2214

WAR: 21

\author{
.
}

ACREAGE (NET): $5,708 \quad 100 \mathrm{~N} / \mathrm{G}: 100 \quad$ LATITUDE: $36^{\circ} 01^{\prime} \quad$ LONGITUDE: $81^{\circ} 50^{\prime}$

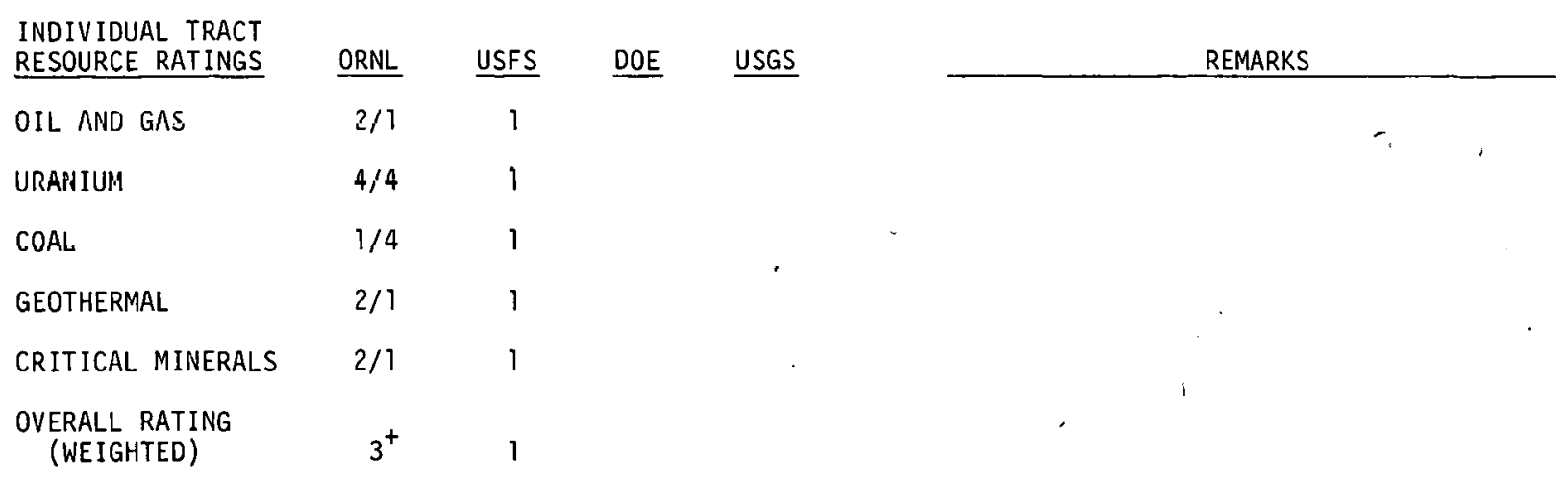

NAMES OF CRITICAL MINERALS PRESENT: Uranium

COMMENTARY AND SUMMARY: This tract is within the Grandfather Mountain Window of the Blue Ridge province. The rocks may be favorable for gas at depth below the basal Blue Ridqe Thrust (Harriș 1976 ). If the Brevard Zone nearby to the southeast is the root zone of the west-directed thrusting (Bryant and Reed 1970), the potential is very slight. Uranium has been reported as occurring on the tract (Bryant and Reed 1966), but none has been mined. The rocks are too old for coal. Hot dry rock at depth may be favorable as a source of geothermal energy. Other than uranium, no critical minerals are known to occur in the tract, but mica, tin, rare earths, and others could occur in pegmatites in the gneiss. In the immediate area, little exploration has occurred for any resource except uranium, for which only minor exploration has taken place.

GEOLOGY: Precambrian Wilson Creek gneiss.

REFERENCE/CITATION: Al1 resources - N.C. Dept. Conserv. and Deveiop., Div. Min. Res., 1959, Geol, Map of N.C.; USGS and USBM, 1968, USGS Prof. Paper 580; Milier and Others, 1970, Mineral Res. of the TVA Region; Bryant and Reed, 1970, USGS Prof. Paper 615; Brobst and Pratt, 1973, USGS Prof. Paper 820; DOE, 1978, Energy Res. Assessments of RARE II Lands; DOE, 1978, Energy Res. Assessments of Ten AIternatives - RARE II Lands; USFS, 1978, RARE II DES, So. Appal. Suppt. 0il and Gas - V1issides and Quirin, 1963, 0i1 and Gas Fields of the U.S.; Cardwe11, 1971, AAPG Mem. 15; USGS, 1974 and 1975, Maps of Appal. Oil and Gas Production; Miller and Others, 1975, USGS Circ. 725; Harris and Milici, 1977, USGS Prof. Paper 1018; Patchen and 0thers, 1978, AAPG Bul1. 8. Uranium - Bryant and Reed, I966, USGS Circ. 521; ERDA, 1976, NURE Prel iminary Report. Coal - Trumbul1, 1960, Coal Fields of the U.S. Geothermal - AAPG, 1976a and b, Geothermal Gradient Map and Subsurface Temperature Map of North America. Critical Minerals - Lesure, 1968, USGS Prof. Paper 577; Oriel, 1950, N.C. Dept. Conserv. and Deve1., Div. Min. Res., Bul1.60. 
ENERGY AND MINERAL RESOURCE EVALUATION - RARE II TRACTS

TRACT NO: L8315

NATIONAL FOREST: Pisgah

TRACT NAME: Harper Creek

ECOREG : 2214

WAR: 19

STATE/COUNTY: North Carolina, Avery/Caldwell

ACREAGE (GROSS): 7,163 ACREAGE (NET): $7,138 \quad 100 \mathrm{~N} / \mathrm{G}: 99.6$ LATITUDE: $35^{\circ} 59^{\prime} \quad$ LONGITUDE: $81^{\circ} 49^{\prime}$

INDIVIDUAL TRACT

RESOURCE RATINGS

$\underline{\text { ORNL }} \quad \underline{\text { USFS }} \quad \underline{\mathrm{DOE}} \quad \underline{\text { USGS }}$

REMARKS

\begin{tabular}{|c|c|}
\hline OIL AND GAS & $2 / 1$ \\
\hline URANIUM & $4 / 4$ \\
\hline COAL & $1 / 4$ \\
\hline GEOTHERMAL & $2 / 1$ \\
\hline CRITICAL MINERALS & $2 / 1$ \\
\hline $\begin{array}{l}\text { OVERALL RATING } \\
\text { (WEIGHTED) }\end{array}$ & $3^{+}$ \\
\hline
\end{tabular}

NAMES OF CRITICAL MINERALS PRESENT: UraniUm

COMMENTARY AND SUMMARY: This tract is within the Grandfather Mountain Window of the Blue Ridge province. Potential for gas may exist at depth below the basal Blue Ridge Thrust (Harris 1976). If the Brevard Zone, nearby to the southeast, is the root zone of the west-directed thrusting (Bryant and Reed 1970), the potential is very slight, and little exploration has occurred. Uranium has been reported as occurring on the tract (Bryant and Reed 1966), but none has been mined. The rocks are too old for coal. Hot dry rock at depth may have some potential as a source of geothermal energy, but little exploration has taken place. Other than uranium, no critical minerals are known to occur in the tract, but mica, tin, rare earths, and others could occur in pegmatites in the gneiss. Little exploration has been performed.

GEOLOGY: Surface rock is the Precambrian Wilson Creek gneiss.

REFERENCE/CITATION: All resources - N.C. Dept. Conserv. and Develop., Div. Min. Res., 1959, Geol. Map of N.C.; USGS and USBM, 1968, USGS Prof. Paper 580; Miller and Others, 1970, Mineral Res. of the TVA Region; Bryant and Reed, 1970, USGS Prof. Paper 615; Brobst and Pratt, 1973, USGS Prof. Paper 820; DOE, 1978, Energy Res. Assessments of RARE II Lands; DOE, 1978, Energy Res. Assessments of Ten Alternatives - RARE II Lands; USFS, 1978, RARE II DES, So. Appal. Suppl. 0il and Gas - V1issides and Quirin, 1963, 0il and Gas Fields of the U.S.; Cardwell, 1971, AAPG Mem. 15; USGS, 1974 and 1975, Maps of Appal. Oil and Gas Production; Miller and Others, 1975, USGS Circ. 725; Harris and Milici, 1977, USGS Prof. Paper 1018; Patchen and Others, 1978, AAPG Bul1. 8. Uranium - Bryant and Reed, 1966, USGS Circ. 521; ERDA, 1976, NURE Preliminary Report. Coal - Trumbull, 1960, Coal Fields of the U.S. Geothermal - AAPG, 1976a and b, Geothermal Gradient Map and Subsurface Temperature Map of North America. Critical Minerals - Lesure, 1968, USGS Prof. Paper 577; Oriel, 1950, N.C. Dept. Conserv. and Devel., Div. Min. Res., Bul1.60. 
ENERGY AND MINERAL RESOURCE EVALUATION - RARE II TRACTS

TRACT NO: 09010

TRACT NAME: Cranberry

ECOREG: 2211

WAR: 21

NATIONAL FOREST: Monongahela

STATE/COUNTY: West Virginia, Pocahontas/Webster

ACREAGE (GROSS): 36,300 ACREAGE (NET): $36,300100 \mathrm{~N} / \mathrm{G}: 100$ LATITUDE: $38^{\circ} 17^{\prime}$ LONGITUDE: $80^{\circ} 18^{\prime}$

TNRIVTHIIAI TRAC.T

RESOURCE RATINGS

$\underline{\text { ORNL }} \underline{\text { USFS }} \underline{\text { DOE }} \underline{\text { USGS }}$

REMARKS

\begin{tabular}{|c|c|c|c|}
\hline OIL AND GAS & $4 / 2$ & 1 & \\
\hline UKANIUUM & $2 / 2$ & 1 & 1 \\
\hline CUAL & $3 / 4$ & 4 & 2 \\
\hline GEOTHERMAL & $2 / 1$ & 1 & \\
\hline C.RITICAL MINERALS & $2 / 2$ & 1 & \\
\hline $\begin{array}{l}\text { VERALL RATING } \\
\text { (WEIGHTED) }\end{array}$ & 3 & . & 2 \\
\hline
\end{tabular}

NAMES OF CRITICAL MINERALS PRESENT: Possible copper, iron, zinc, lead, cadmium, fluorite, and barite at depth

COMMENTARY AND SUMMARY: This tract is in the Appalachian Plateau province. The rocks are favorabie for $0 i 1$ and gas, which are produced throughout the province in the study area. Sandslune units may be favorable for deposits of uranium. This tract is situated on the edge of the Appalachian coal field. coal underlies part of the tract but is thin and of low quality. Hot dry rock at depth may be favorable as a source of geothermai energy. The surface rocks probably contain no critical minerals, but older rocks at depth may be favorable for copper (Upper Devonian red beds); zinc and lead (Devonian Oriskany Sandstone); iron (Devonian Helderberg Limestone and Silurian Clinton Formation); and zinc, cadmium, lead, fluorite, and barite (Ordovician carbonates). Little exploration has occurred for any resources, except for oil, gas, and coal in the immediate area.

GEOLOGY: Surface rocks are Upper Mississippian and Lower Pennsylvanian shales and sandstones mostly flat-lying but with a few local folds and faults.

REFERENCE/CITATION: All resources - Stose and Ljungstedt, 1932, Geol. Map of W. Va.; USGS and USBM, 1968, USGS Prof. Paper 580; Miller and Others, 1970, Mineral Res. of the TVA Region; Brobst. and Pratt, 1973, USGS Prof. Paper 820; DOE, 1978, Energy Res. Assessments of RARE II Lands; DOE, 1978, Energy Res. Assessments of Ten Alternatives - RARE II Lands; USFS, 1978, RARE II DES, So. Appal. Suppl. 0 il and Gas - V1 issides and Quirin, 1U63, U1 I and lias Fields of the U.5.; Cardwel1, 1971, AAPG Melll. 15; USGS, 1974 and 1975, Maps of Appal. Oil and Gas Production; Miller and Others, 1975, USGS Circ. 725; Harris and Milici, 1977, USGS Prof. Paper 1018; Patchen and Others, 1978, AAPG Bu11. 62: 1399-1441. Uranium - ERDA, 1976, NURE Preliminary Report. Coal - Trumbu11, 1960, Coal Fields of the U.S. Geothermal - AAPG, 1976a and b, Geothermal Gradient Map and Subsurface Temperature Map of North America. 
NATIONAL FOREST: Monongahela -

ACREAGE (GROSS): 7,720 ACREAGE (NET): 7,720
STATE/COUNTY: West Virginia, Randolph

$100 \mathrm{~N} / \mathrm{G}: 100$ LATITUDE: $38^{\circ} 47^{\prime}$ LONGITUDE: $79^{\circ} 47^{\prime \prime}$

\begin{tabular}{|c|c|c|c|c|c|}
\hline $\begin{array}{l}\text { INDIVIDUAL TRACT } \\
\text { RESOURCE RATINGS } \\
\end{array}$ & $\underline{\text { ORNL }}$ & USFS & $\underline{\mathrm{DOE}}$ & $\underline{\text { USGS }}$ & REMARKS \\
\hline OIL AND GAS & $4 / 2$ & 1 & & & $\begin{array}{l}\text { Three miles west of Glady gas field } \\
\text { (Patchen and Others 1978) }\end{array}$ \\
\hline URANIUM & $2 / 1$ & 1 & 1 & & \\
\hline COAL & $4 / 4$ & 1 & 3 & & Within Appalachian Coal Field \\
\hline GEOTHERMAL & $2 / 1$ & 1 & & & \\
\hline CRITICAL MINERALS & $2 / 1$ & 1 & & & \\
\hline $\begin{array}{l}\text { OVERALL RATING } \\
\text { (WEIGHTED) }\end{array}$ & $2^{+}$ & 1 & & & Gas pipeline may cross tract \\
\hline
\end{tabular}

NAMES OF CRITICAL MINERALS PRESENT: Possible copper, iron, lead, zinc, cadmium, barite, and fiuorite at depth

COMMENTARY AND SUMMARY: This tract is in the Appalachian Plateau. The rocks are very favorable for oil and gas, which are produced throughout the province. Sandstone units may be favorable for uranium. This tract is located within the Appalachian coal field and overlies thick, high-quality coal seams. Hot dry rock at depth may be favorable as a source of geothermal energy. The surface rocks contain no critical minerals. The subsurface rocks may be favorable for copper (Upper Devonian red beds); zinc and lead (Devonian Oriskany Sandstone); iron (Devonian Helderberg Limestone and Silurian Clinton Formation); and zinc, cadmium, lead, fluorite, and barite (Ordovician carbonates). Little exploration has been performed for all resources except for $0 i 1$, gas, and coal in the immediate area.

GEOLOGY: Surface rocks are Upper Mississippian and Lower Pennsylvanian shales and sandstones sylicl illally ruldeid.

REFERENCE/CITATION: All resources - Stose and Ljungstedt, 1932, Geol. Map of W. Va.; USGS and USBM; 1968, USGS Prof. Paper 580; Mi1ler and Others, 1970, Mineral Res. of the TVA Region; Brobst and Pratt, 1973, USGS Prof. Paper 820; DOE, 1978, Energy Res. Assessments of RARE II Lands; DOE, 1978, Energy Res. Assessments of Ten Alternatives - RARE II Lands; USFS, 1978, RARE II DES, So. Appal. Suppl. 0il and Gas - Vlissides and Quirin, 1963, 0i1 and Gas Fields of the U.S.; Cardwel1, 1971, AAPG Mem. 15; USGS, 1974 and 1975, Maps of Appal. Oil and Gas Production; Miller and Others, 1975, USGS Circ. 725; Harris and Milici, 1977, USGS Prof. Paper 1018; Patchen and 0thers, 1978, AAPG Bu11. 62: $1399-1441$. Uranium - ERDA, 1976, NURE Prel iminary Report. Coal - Trumbull, 1960, Coal Fields of the U.S. Geothermal - AAPG, 1976a and b, Geothermal Gradient Map and Subsurface Temperature Map of North Americá. 
TRACT NO: 09041

NATIONAL. FOREST: Monongahela

ACREAGE (GROSS): 20,780 ACREAGE (NET): 19,660

TRACT NAME: Seneca Creek

ECOREG: 2214

WAR: 20

STATE/COINTY: West Virginia, Randolph/Pendleton

$100 \mathrm{~N} / \mathrm{G}: 95$ LATITUDE: $38^{\circ} 46^{\prime}$ LONGITUDE: $79^{\circ} 31^{\prime}$

INDIVIDUAL TRACT

RESOURCE RATINGS

$\underline{\text { ORNL }} \underline{\text { USFS }} \quad \underline{\mathrm{DOE}} \quad \underline{\text { USGS }}$

GEOTHERMAL
OIL AND GAS

$4 / 2 \quad 1$

UIRANIUM

C.MAI

CRITICAL MINERALS

$2 / 1$

$1 / 4$

$2 / 1$

$2 / 1$

2

1

1

3

1

1

OVERALL RATING (WEIGHTED)

REMARKS

Five miles east of Glady gas field (Patchen and Uthers 1978)

NAMES OF CRITICAL MINERALS PRESENT: Possible copper; possible iron, lead, zinc, cadmium, fluorite, and barite at depth

COMMENTARY AND SUMMARY: This tract is in the fold-dominated part of the Valley and Ridge. The rocks are quite favorable for oil and gas, although some hydrocarbons may have been driven off by heat from metamorphism and igneous activity in the nearby Blue Ridge, heat that also made gas more common than oil throughout the province. These hydrocarbons are produced in several places in the province in the study area. This tract has unusually high favorability for petroleum because of its location with respect to a gas-producing anticline. sandstone units may be favorable for uranluill. The rucks dret too old to contain coal. Hot dry rock at depth may be favorable as a source of yeuthermal energy. The Upper Devonian red beds at the surface may contain the critical mineral copper. Critical minerals for which the subsurface rocks may be favorable include zinc and lead (Devonian Oriskany Sandstone); iron (Devonian Helderberg Limestone and Silurian Clinton Formation); and zinc, cadmium, lead, fluorite, and barite (Ordovician carbonates). Little exploration has occurred for any commodity except for oil and gas, which has been only moderate.

GEOLOGY: Surface rocks are Upper Devonian and Mississippian shales and sandstones synclinally and anticlinally tolded.

REFERENCE/CITATION: All resources - Stose and Ljungstedt, 1932, Geol. Map of W. Va.; USGS and USBM, 1968. USGS Prof. Paper 580; Mi11er and Others, 1970, Mineral Res. of the TVA Region; Rrobst and Pratt. 1973, USGS Prof. Paper 820; DOE, 1978, Energy Res. Assessments of RARE II Lands; DOE, 1978, Energy Res. Assessments of Ten Alternatives - RARE II Lands; USFS, 1978, RARE II DES, So. Appa1. Supp1. Oil and Gas - Vlissides and Quirin, 1963, 0i1 and Gas Fields of the U.S.; Cardwe 11, 1971, AAPG Mem. 15; USGS, 1974 and 1975, Maps of Appal. Oil and Gas Production; Miller and 0thers, 1975, .USGS Circ. 725 ; Harris and Milici, 1977, USGS Prof. Paper 1018; Patchen and Others, 1978, AAPG Bu11. 62: 1399-1441. Uranium - ERDA, 1976, NURE Preliminary Report. Coal - Trumbul1, 1960, Coal Fields of the U.S. Geothermal - AAPG, 1976a and b, Geothermal Gradient Map and Subsurface Temperature Map of North America. 
ENERGY AND MINERAL RESOURCE EVALUATION - RARE II TRACTS

TRACT NO: 09042

TRACT NAME: North Mountain Hopeville

ECOREG: 2214 WAR: 19

NATIONAL FOREST: Monongahela

ACREAGE (GROSS): 7,040 ACREAGE (NET): 5,410
STATE/COUNTY: West Virginia, Grant

$100 \mathrm{~N} / \mathrm{G}: 77$ LATITUDE: $38^{\circ} 57^{\prime}$ LONGITUDE: $79^{\circ} 16^{\prime}$
INDIVIDUAL TRACT

RESOURCE RATINGS

OIL AND GAS

URANIUM

COAL

GEOTHERMAL

CRITICAL MINERALS

OVERALL RATING

(WEIGHTED)

\begin{tabular}{|c|c|c|}
\hline ORNL & $\underline{\text { USFS }}$ & $\mathrm{DOE}$ \\
\hline $4 / 2$ & 1 & \\
\hline $2 / 1$ & 1 & 1 \\
\hline $1 / 4$ & 1 & 3 \\
\hline $2 / 1$ & 1 & \\
\hline $3 / 2$ & 1 & \\
\hline 2 & 1 & 3 \\
\hline
\end{tabular}

REMARKS

On an anticline

Mineral-bearing units closer to surface

NAMES OF CRITICAL MINERALS PRESENT: Possible manganese, iron, zinc, and lead; possible zinc, lead, cadmium, barite, and fluorite at depth

COMMENTARY ANC SUMMARY: This tract is in the fold-dominated part of the Valley and Ridge. The rocks are quite favorable for oil and gas, al though some hydrocarbons may have been driven off by heat from metamorphism and igneous activity in the nearby Blue Ridge, heat that also would make gas more common than oil throughout the province. These hydrocarbons are produced in several places in the province in the study area. Sandstone units may be favorable for uranium. The rocks are too old to contain coal. Hot dry rock at depth may be favorable as a source of geothermal energy. The surface rocks. are quite favorable for critical minerals: manganese, zinc, and lead in the weathered Devonian Oriskany Sandstone and iron in the Devonian Helderberg Limestone and Silurian Clinton Formation. Zinc, lead, cadmium, fluorite, and barite may also be present in Ordovician carbonates below the surface. Little exploration has occurred for any commodity except for oil and gas, which has been only moderate.

GEOLOGY: Surface rocks are Upper Ordovician to Lower Devonian shales and sandstones anticlinally folded.

REFERENCE/CITATION: A11 resources - Stose and Ljungstedt, 1932, Geol. Map of W. Va.; USGS and USBM, 1968, USGS Prof. Paper 580; Miller and Others, 1970, Mineral Res. of the TVA Region; Brobst and Pratt, 1973, USGS Prof. Paper 820; DOE, 1978, Energy Res. Assessments of RARE II Lands; DOE, 1978, Energy Res. Assessments of Ten Alternatives - RARE II Lands; USFS, 1978, RARE II DES, So. Appal. Supp I. 0il and Gas - Vlissides and Quirin, 1963, 0il and Gas Fields of the U.S.; Cardwell, 1971, AAPG Mem. 15; USGS, 1974 and 1975, Maps of Appal. Oil and Gas Production; Millèr and Others, 1975, USGS Circ. 725; Harris and Milici, 1977, USGS Prof. Paper 1018; Patchen and 0thers, 1978, AAPG Bu11. 62: 1399-1441. Uranium - ERDA, 1976, NURE Preliminary Report. Coal - Trumbu11, 1960, Coal Fields of the U.S. Geothermal - AAPG, $1976 a$ and b, Geothermal Gradient Map and Subsurface Iemperature Map of North America. 
ENERGY AND MINERAL RESOURCE EVALUATION - RARE II TRACTS

TRACT NO: 09043

TRACT NAME: Canaan Loop

ECOREG: 2214 WAR: 16

NATIONAL FOREST: Monongahela

STATE/COUNTY: West Virginia, Tucker

ACREAGE (GROSS): 7,240 ACREAGE (NET): 7,240 $100 \mathrm{~N} / \mathrm{G}: 100$ LATITUDE: $39^{\circ} 06^{\prime}$ LONGITUDE: $79^{\circ} 29^{\prime}$

INDIVIDUAL TRACT

RESOURCE RATINGS

OIL AND' GAS

$\underline{\text { ORNL }} \underline{\text { USFS }} \quad \underline{D O E} \quad \underline{\text { USGS }}$

REMARKS

$\begin{array}{lllll}\text { URANIUM } & & & \begin{array}{l}\text { BTackwater Anticline (Patchen } \\ \text { 1978) }\end{array} \\ \text { COAL } & 2 / 1 & 1 & 1 & \text { Within Appalachian coal field } \\ \begin{array}{l}\text { GEOTHERMAL } \\ \text { CRITICAL MINERALS }\end{array} & 4 / 4 & 1 & 3 & \\ \begin{array}{l}\text { OVERALL RATING } \\ \text { (WEIGHTED) }\end{array} & 2 / 1 & 1 & 1 & \end{array}$

NAMES OF CRITICAL MINERALS PRESENT: Possible copper, iron, zinc, lead, cadmium, barite, and fluorite at depth

COMMENTARY AND SUMMARY: This tract is in the Appalachian Plateau. The rocks are very favorable for oil and gas, which are produced throughout the province. Sandstone units may be favorable for uranium. This tract is located within the Appalachian coal field and overlies thick, high-quality coal seams. Hot dry rock at depth may be favorable as a source of geothermal energy. The surface rocks contain no critical minerals. The subsurtace rocks may be tavorable for copper (Upper Devunidn red bejs), zinc and lead (Devonian Oriskany Sandstone); iron (Devonian Helderberg Limestone and Silurian Clinton Formation); and zinc, cadmium, lead, fluorite, and barite (Ordovician carbonates). Little exploration has been performed for a 11 resources except for oil, gas, and coal in the immediate area.

GEOLOGY: Surface rocks are Lower Pennsylvanian shales and sandstones, essentially flat-lying within a syncline.

REFERENCE/CITATION: A11 resources - Stose and Ljungstedt, 1932, Geol. Map of W. Va.; USGS and USBM, 1968, USGS Prof. Paper 580; Miller and Others, 1970, Mineral Res. of the TVA Region; Brobst and Pratt, 1973, USGS Prof. Paper 820; DOE, 1978, Energy Res. Assessments of RARE II Lands; DOE, 1978, Energy Res. Assessments of Ten Alternatives - RARE II Lands; USFS, 1978, RARE II DES, So. Appal. Suppl. $0 i 1$ and Gas - VIissides and Quirin, 1963, 0i1 and Gas Fields of the U.S.; Cardwel1, 1971, AAPG Mem. 15; USGS, 1974 and 1975, Maps of Appal. Oij and Gas Production; Miller and Uthers, 1975, USGS C1rC. 725; Harris and Milici, 1977, USGS Prof. Paper 1018; Patchen and 0thers, 19\%8, AAPG Bu11. 62: 1399-1441. Uranium - ERDA, 1976, NURE Prel iminary Report. Coal - Trumbu11, 1960, Coal Fields of the U.S. Geothermal - AAPG, 1976a and b, Geothermal Gradient Map and Subsurface Temperature Map of North America. 
ENERGY AND MINERAL RESOURCE EVALUATION - RARE II TRACTS

TRACT NO: 09044

TRACT NAME: Laurel Fork North

ECOREG : 2214

WAR: 20

NATIONAL FOREST: Monongahela

ACREAGE (GROSS): 6,120 ACREAGE (NET): 6,120
STATE/COUNTY: West Virginia, Randolph

$100 \mathrm{~N} / \mathrm{G}: 100$ LATITUDE: $38^{\circ} 47^{\prime}$ LONGITUDE: $79^{\circ} 38^{\prime}$
INDIVIDUAL TRACT

RESOURCE RATINGS

OIL AND GAS

$\underline{\text { ORNL }} \quad \underline{\text { USFS }} \quad \underline{\mathrm{DOE}} \quad \underline{\text { USGS }}$

URANIUM

COAL

GEOTHERMAL

CRITICAL MINERALS

OVERALL RATING

(WEIGHTED)
$4 / 4 \quad 1$

$4 / 4$

$\begin{array}{ll}2 / 1 & 1 \\ 1 / 4 & 1 \\ 2 / 1 & 7 \\ 2 / 1 & 1\end{array}$

3

3

\section{REMARKS}

In known gas field (Patchen and 0thers 1978)

\section{1}

3

Gas pipeline may cross tract

NAMES OF CRITICAL MINERALS PRESENT: Possible copper; possible iron, zinc, lead, cadmium, bar1te, and fluorite at depth

COMMENTARY AND SUMMARY: This tract is in the fold-dominated part of the Valley and Ridge. The rocks are quite favorable for oil and gas, although some hydrocarbons may have been driven off by heat from metamorphism and igneous activity in the nearby Blue Ridge, heat that also made gas more common than oif throughout the province. These hydrocarbons are produced in several places in the province in the study area. This tract has unusually high favorability for petroleum because of its location with respect to a gas-producing anticline. Sandstone units may be favorable for uranium. The rocks are too old to contain coal. Hot dry rock at depth may be favorable as a source of geothermal energy. The Upper Devonian red beds at the surface may contain the critical mineral copper. Critical minerals for which the subsurface rocks may be favorable include zinc and lead (Devonian Oriskany Sandstone); iron (Devonian Helderberg Limestone and Silurian Clinton Formation); and zinc, cadmium, lead, fluorite, and barite (Ordovician carbonates). Little exploration has occurred for any commodity except for oil and gas, which has bcen only moderate.

GEOLOGY: Surface rocks are mostly Upper Devonian with a few Lower Mississippian shales and sandstones on the east flank of an anticline.

REFERENCE/CITATION: A11 resources - Stose and Ljungstedt, 1932, Geol. Map of W. Va.; USGS and USBM, 1968, USGS Prof. Paper 580; Miller and Others, 1970, Mineral Res. of the TVA Region; Brobst and Pratt, 1973, IJSGS Prof. Paper 820; DOE, 1978. Energy Res. Assess\$mențs of RARE II Lands; D0E, 1978, Energy Res. Assessments of Ten Alternatives - RARE II Lands; USFS, 1978, RARE II DES, So. Appa $\overline{1}$. Supp $\overline{1}$. 0 $01 \overline{1}$ and Gas - Vlissides and Quirin, 1963, 0il and Gas Fields of the U.S.; Cardwe11, 1971, AAPG Mem. 15; USGS, 1974 and 1975, Maps of Appal. Oil and Gas Production; Miller and Others, 1975, USGS Circ. 725; Harris and Milici, 1977, USGS Prof. Paper 1018; Patchen and 0thers, 1978, AAPG Bul1. 62: 1399-1441. Uranium - ERDA, 1976, NURE Prel iminary Report. Coal - Trumbu11, 1960, Coal Fields of the U.S. Geothermal - AAPG, 1976a and b, Geothermal Gradient Map and Subsurface Temperature Map of North America. 
ENERGY AND MINERAL RESOURCE EVALUATION - RARE II TRACTS

TRACT NO: 09045

TRACT NAME: Laurel Fork South

ECOREG: 2214

WAR: 20

NATIONAL FOREST: Monongahela

STATE/COUNTY: West Virginia, Randolph

ACREAGE (GROSS): 5,920 ACREAGE (NET): $5,920100 \mathrm{~N} / \mathrm{G}: 100$ LATITUDE: $38^{\circ} 43^{\prime}$ LONGITUDE: $79^{\circ} 41^{\prime}$

INDIVIDUAL TRACT

RESOURCE RATINGS

ORNL USFS DOE USGS

REMARKS

OIL AND GAS

$4 / 4 \quad 1$

URANIUM

COAL

GEOTHERMAL

$2 / 1$

11

$1 / 4$

1

3

C.RITICAL MINERALS $2 / 1 \quad 1$

OVERALL RATING

(WEIGHTED)

3

REMARKS
$\begin{aligned} & \text { In known gas field (Patchen and Others } \\ & 1978 \text { ) }\end{aligned}$

NAMES OF CRITICAL MINERALS PRESENT: Possible copper; possible iron, zinc, lead, cadmium, barite, and fluorite at depth

CUMMENIAKY ANU SUMMAKY: Ihis tract is in the fold-dominated part of the Valley and Ridge. The rocks are quite favorable for $0 i l$ and gas, although some hydrocarbons may have been driven off by heat from metamorphism and igneous activity in the nearby Blue Ridge, heat that also made gas more common than oil throughout the province. These hydrocarbons are produced in several places in the province in the study area. This tract has unusually. high favorability for petroleum because of its location with respect to a gas-producing anticline. Sandstone units may be favorable for uranium. The rocks are too old to contain coal. Hot dry rock at depth may be favorable as a source of geothermal energy. The Upper Devonian red beds at the surface may contain the critical mineral copper. Critical minerals for which the subsurface rocks may be favorable include zinc and lead (Devonian Oriskany Sandstone); iron (Devonian Helderberg Limestone and Silurian Clinton Formation); and zinc, cadmium, lead, fluorite, and barite (Ordovician carbonates). Little exploration has occurred for any commodity except for oil and gas, which has been only moderate.

GEOLOGY: Surface rocks are mostly Upper Devonian with a few Lower Mississippian shales and sandstones on the east flank of an anticline.

REFERENCE/CITATION: A11 resources - Stose and Ljungstedt, 1932, Geol. Map of W. Va.; USGS and USBM, 1968, USGS Prof. Paper 580; Miller and Others, 1970, Mineral Res. of the TVA Region; Brobst and Pratt, 1973, USGS Prof. Paper 820; DOE, 1978, Energy Res. Assessments of RARE II Lands; D0E, 1978, Energy Res. Assessments of Ten Alternatives - RARE II Lands; USFS, 1978, RARE II DES, So. Appal. Supp I. 0i1 and Gas - V1issides and Quirin, 1963, 011 and Gas Fields of the U.S.; Cardwel1, 1971, AAPG Mem. 15; USGS, T974 and 1975, Maps of Appal. Oil and Gas Production; Miller and Others, 1975, USGS Circ. 725; Harris and Milici, 1977, USGS Prof. Paper 1018; Patchen and 0thers, 1978, AAPG Bul1. 62: 1399-1441. Uranium - ERDA, 1976, NURE Prel iminary Report. Coal - Trumbul1, 1960, Coal Fields of the U.S. Geothermal - AAPG; 1976 a and b, Geothermal Gradient Map and Subsurface Temperature Map of North America. 
INDIVIDUAL TRACT RESOURCE RATINGS

OIL AND GAS

$\underline{O R N L} \quad \underline{\text { USFS }} \quad \underline{\mathrm{DOE}} \quad \underline{\mathrm{USGS}}$ REMARKS

$\begin{array}{lccc}\text { URANIUM } & 2 / 2 & 1 & 1 \\ \text { COAL } & 2 / 4 & 4 & 3 \\ \text { GEOTHERMAL } & 2 / 1 & 1 & \\ \begin{array}{l}\text { CRITICAL MINERALS } \\ \begin{array}{l}\text { OVERALL RATING } \\ \text { (WEIGHTED) }\end{array}\end{array} & 2 / 2 & 4 & \\ & 2^{+} & & 3\end{array}$

NAMES OF CRITICAL MINERALS PRESENT: Possible copper, iron, lead, zinc, cadmium, fluorite, and barite at depth

COMMENTARY AND SUMMARY: This tract is in the Appalachian Plateau province. The rocks are favorable for $0 i l$ and gas, which are produced throughout the province in the study area. Sandstone units may be favorable for deposits of uranium. This tract is situated on the edge of the Appalachian coal field. coal underlies part of the tract but is thin and of low quality. Hot dry rock at depth may be favorable as a source of geothermal energy. The surface rocks probably contain no critical minerals, but older rocks at depth may be favorable for copper (Upper Devonian red beds); zinc and lead (Devonian Oriskany Sandstone); iron (Devonian Helderberg Limestone and Silurian Clinton Formation); and zinc, cadmium, lead, fluorite, and barite (Ordovician carbonates). Little exploration has occurred for any resources, except for $0 i 1$, gas, and coal in the immediate area.

GFMInGY: Surface rocks are Upper Mississippian and Lower Pennsylvanian shales and sandstones, mostly flat-lying but with occasional folds and faults.

REFERENCE/CITATION: All resources - Stose and Ljungstedt, 1932, Geol. Map of W. Va.; USGS and USBM, 1968, USGS Prof. Paper 580; Miller and Others, 1970, Mineral Res. of the TVA Region; Brobst and Pratt, 1973, UISGS Prof. Paper 820; DOE, 1978, Energy Res. Assessments of RARE II Lands; D0E, 1978, Energy Res. Assessments of Ten Alternatives - RARE II Lands; USFS, 1978, RARE II DES, So. Appal. Suppl. 0i1 and Gas - VIissides and Quirin, 1963, 0 il and Gas Fields of the U.S.; Cardwe11, 1971, AAPG Mem. 15; USGS, 1974 and 1975, Maps of Appal. 0il and Gas Production; Miller and Others, 1975, USGS Circ. 725; Harris and Milici, 1977, USGS Prof. Paper 1018; Patchen and Others, 1978, AAPG Bul1. 62: 1399-1441. Uranium - ERDA, 1976, NURE Prel iminary Report. Coal - Trumbull, 1960, Coal Fields of the U.S. Gent.hermal - AAPG, 1976a and b, Geothermal Gradient Map and Subsurface Temperature Map of North America. 
ENERGY AND MINERAL RESOURCE EVALUATION - RARE II TRACTS

TRACT NNO: 09048

TRACT NAME: Tea Creek Mountain

ECOREG: 2211

WAR: 18

NATIONAI, FOREST: Monongahela

STATE/COUNTY: West Virginia, Pocahontas

ACREAGE (GROSS): 10,120 ACREAGE (NET): $10,100 \quad 100 \mathrm{~N} / \mathrm{G}: 99.8$ LATITUDE: $38^{\circ} 22^{\prime}$ LONGITUDE: $80^{\circ} 10^{\prime}$

INDIVIDUAL TRACT

RESOURCE RATINGS

$\underline{\text { ORNL }} \underline{\text { USFS }} \underline{\text { DOE }} \quad \underline{\text { USGS }}$

REMARKS

OIL AND GAS

$4 / 2 \quad 4$

URANIUM

$2 / 2 \quad 1$

COAL

$2 / 4$

4

1

GEOTHERMAL

$2 / 1$

1

CRITICAL MINERALS

$2 / 2$

4

OVIRALL RATING

(WEIGHTED)

$2^{+}$

2

NAMES OF CRITICAL MINERALS PRESENT: Possible copper, iron, zinc, lead, cadmium, fluorite, and barite at depth

COMMENTARY AND SUMMARY: This tract is in the Appalachian Plateau province. The rocks are favorable for $0 i 1$ and gas, which are produced throughout the province in the study area. Sandstone units may be favorable for deposits of uranium. This tract is situated on the edge of the Appalachian coal field. Coal underlies part of the tract but is thin and of low quality. Hot dry rock at depth may be favorable as a source of geothermal energy. The surface rocks probably contain no critical minerals, but older rocks at depth may be favorable for copper (Upper Devonian red beds); zinc and lead (Uevonian Oriskany Sandstone); iron (Devonian Helderberg Limestone and Silurian Clinton Formation); and zinc, cadmium, lead, fluorite, and barite (Ordovician carbonates). Little exploration has occurred for any resources, except for $0 i 1$, gas, and coal in the immediate area.

GEOLOGY: Surface rocks are Upper Mississippian and Lower Pennsylvanian shales and sandstones mostly flat iying but with a few local folds and faults.

REFERENCE/CITATION: All resources - Stose and Ljungstedt, 1932, Geol. Map of W. Va.; USGS and USBM, 1968, USGS Prof. Paper 580; Miller and Others, 1970, Mineral Res. of the TVA Region; Brobst and Pratt, 1973, USGS Prof. Paper 820; DOE, 1978, Energy Res. Assessments of RARE II Lands; DOE, 1978, Energy Res. Assessments of Ten A7ternatives - RARE II Lands; USFS, 1978, RARE II DES, So. Appal. Suppl. 0i1 and Gas - Viissides and Quirin, 1963, 011 and Gas Fields of the U.S.; Cardwe T1, 1971, AAPG Mem. 15; USGS, T974 and 1975, Maps of Appal. Oil and Gas Production; Miller and Others, 1975, USGS Circ. 725; Harris and Milici, 1977, USGS Prof. Paper 1018; Patchen and Others, 1978, AAPG Bu11. 62: 1399-1441. Uranium - ERDA, 1976, NURE Preliminary Report. Coal - Trumbu11, 1960, Coal Fields of the U.S. Geothermal - AAPG, 1976a and b, Geothermal Gradient Map and Subsurface Temperature Map of North America. 
ENERGY AND MINERAL RESOURCE EVALUATION - RARE II TRACTS

TRACT NO: 09049

TRACT NAME: Falls of Hills Creek

ECOREG : 2211

WAR: 13

NATIONAL FOREST: Monongahela

STATE/COUNTY: West Virginia, Pocahontas/Greenbrier

ACREAGE (GROSS): 7,640 ACREAGE (NET): 6,800

$100 \mathrm{~N} / \mathrm{G}: 89 \quad$ LATITUDE: $38^{\circ} 11^{\prime}$

LONGITUDE: $80^{\circ} 19^{\prime}$

\begin{tabular}{|c|c|c|c|c|}
\hline $\begin{array}{l}\text { INDIVIDUAL TRACT } \\
\text { RESOURCE RATINGS } \\
\end{array}$ & $\underline{\text { ORNL }}$ & $\underline{\text { USFS }}$ & $\underline{\mathrm{DOE}}$ & USGS \\
\hline OIL AND GAS & $4 / 2$ & 1 & & \\
\hline URANIUM & $2 / 2$ & 1 & 1 & \\
\hline COAL & $2 / 4$ & 1 & 2 & \\
\hline GEOTHERMAL & $2 / 1$ & 1 & & \\
\hline CRITICAL MINERALS & $2 / 2$ & 1 & & \\
\hline $\begin{array}{l}\text { OVERALL RATING } \\
\text { (WEIGHTED) }\end{array}$ & $2^{+}$ & 1 & & \\
\hline
\end{tabular}

NAMES OF CRITICAL MINERALS PRESENT: Possible copper, iron, zinc, lead, cadmium, barite, and fluorite at depth

COMMENTARY AND SUMMARY: This tract is in the Appalachian Plateau province. The rocks are favorable for 0 il and gas, which are produced throughout the province in the study area. Sandstone units may be favorable for deposits of uranium. This tract is situated on the edge of the Appalachian coal field. Coal underlies part of the tract but is thin and of low quality. Hot dry rock at depth may be favorable as a source of geothermal energy. The surface rocks probably contain no critical minerals, but older rocks at depth may be favorable for copper (Upper Devonian red beds); zinc and lead (Devonian Oriskany Sandstone); iron (Devonian Helderberg Limestone and Silurian Clinton Formation); and zinc, cadmium, lead, fluorite, and barite (Ordovician carbonates). Little exploration has occurred for any resources, except for oil, gas, and coal in the immediate area.

GEOLOGY: Surface rocks are Upper Mississippian and Lower Pennsylvanian shales and sandstones, mostly flat lying but with a few local folds and faults.

REFERENCE/CITATION: All resources - Stose and Ljungstedt, 1932, Geol. Map of W. Va.; USGS and USBM, 1968, USGS Prof. Paper 580; Miller and Others, 1970, Mineral Res. of the TVA Region; Brobst and Pratt, 1973, USGS Prof. Paper 820; DOE, 19\%8, Energy Res. Assessments of RARE I I Lands; DOE, 1978, Energy Res. Assessments of Ten Alternatives - RARE II Lands; USFS, 1978, RARE II DES, So. Appal. Suppl. 0il and Gas - Vlissides and Quirin, 1963, 0il and Gas Fields of the U.S.; Cardwell, 1971, AAPG Mem. 15; USGS, 1974 and 1975, Maps of Appal. Oil and Gas Production; Miller and 0thers, 1975, USGS Circ. 725; Harris and Milici, 1977, USGS Prof. Paper 1018; Patchen and Others, 1978, AAPG Bu11. 62: 1399-1441. Uranium - ERDA, 1976, NURE Preliminary Report. Coal - Trumbul1, 1960, Coal Fields of the U.S. Geothermal - AAPG, 1976a and b, Geothermal Gradient Map and Subsurface Temperature Map of North America. 
ENERGY AND MINERAL RESOURCE EVALUATION - RARE II TRACTS

TRACT N0: 09050

TRACT NAME: Middle Mountain

ECOREG: 2214

WAR: 20

NATIONAL FOREST: Monongahela

STATE/COUNTY: West Virginia, Pocahontas/Greenbrier ACREAGE (GROSS): 19,240 ACREAGE (NET): $18,920 \quad 100 \mathrm{~N} / \mathrm{G}: 98$ LATITUDE: $38^{\circ} 04^{\prime} \quad$ LONGITUDE: $80^{\circ} 02^{\prime}$

INDIVIDUAL TRACT

RESOURCE RATINGS

OIL AND GAS

$\underline{\text { ORNL }} \underline{\text { USFS }} \underline{\text { DOE }} \underline{\text { USGS }}$

$4 / 2 \quad 1$

UR.ANIUM

COAL

GEOTHERMAL

CRITICAL MINERALS

$$
2 / 1
$$

$1 / 4$

1

1

1 -

3

$\begin{array}{ll}2 / 1 & 1 \\ 3 / 2 & 1\end{array}$

OVERALL RATING

(WEIGHTED)

$$
1
$$

$2^{+}$
REMARKS

Near Brown's Mountain Anticline, which is nn st.rike with gas-hearing Blarkwater Anticline (Patchen and Others 1978)

NAMES OF CRITICAL MINERALS PRESENT: Possible copper; possible iron, lead, zinc, cadmium, barite, and fluorite at depth

COMMENTARY AND SUMMARY: This tract is in the fold-dominated part of the Valley and Ridge. The rocks are quite favorable for oil and gas, although some hydrocarbons may have been driven off by heat from metamorphism and igneous activity in the nearby Blue Ridge, heat that also made gas more common than oil throughout the province. These hydrocarbons are produced in several places in the province in the study area. This tract has unusually high favorability for petroleum because of its location with respect to a gas-producing anticline. Sandstone units may be favorable for uranium. The rocks are too old to contain coal. Hot dry rock at depth may be favorable as a source of geothermal energy. The Upper Devonian red beds at the surface may contain the critical mineral copper. Critical minerals for which the subsurface rocks may be favorable include zinc and lead (Devonian Oriskany Sandstone); iron (Devonian Helderberg Limestone and Silurian Clinton Formation); and zinc, cadmium, lead, fluorite, and barite (Ordovician carbonates). Little exploration has occurred for any commodity except for oil and gas, which has been only moderate.

GEOLOGY: Surface rocks are Middle and Upper Devonian shales and sandstones anticlinally folded.

REFERENCE/CITATION: A11 resources - Stose and Ljungstedt, 1932, Geol. Map of W. Va.; USGS and USBM, 1968, USGS Prof. Paper 580; Miller and Others, 1970, Mineral Res. of the TVA Region; Brobst and Pratt, 1973, USGS Prof. Paper 820; D0E, 1978, Energy Res. Assessments of RARE II Lands; D0E, 1978, Energy Res. Assessments of Ten Alternatives - RARE II Lands; USFS, 1978, RARE II DES, So. Appal. Suppl. 0il. and Gas - V1issides and Quirin, 1963, 011 and Gas Fields of the U.S.; Cardwe11, 1971, AAPG Mem. 15; USGS, 1974 and 1975, Maps of Appal. Oil and Gas Production; Miller and Others, 1975, USGS Circ. 725; Harris and Milici, 1977, USGS Prof. Paper 1018; Patchen and Others, 1978, AAPG Bul1. 62: 1399-1441. Uranium - ERDA, 1976, NURE Preliminary Report. Coal - Trumbul1, 1960, Coal Fields of the U.S. Geothermal - AAPG, 1976a and b, Geothermal Gradient Map and Subsurface Temperature Map of North America. 
INDIVIDUAL TRACT RESOURCE RATINGS

OIL AND GAS $\underline{\text { ORNL }} \underline{\text { USFS }} \underline{\text { DOE }} \underline{\text { USGS }}$

$\begin{array}{lccc}\text { OIL AND GAS } & 4 / 2 & 1 & \\ \text { URANIUM } & 2 / 1 & 1 & 1 \\ \text { COAI. } & 1 / 4 & 1 & 3 \\ \text { GEOTHERMAL } & 2 / 1 & 1 & \\ \text { CRITICAL MINERALS } & 2 / 1 & 1 & \\ \begin{array}{l}\text { OVERALL RATING } \\ \text { (WEIGHTED) }\end{array} & 2- & \end{array}$

NAMES OF CRITICAL MINERALS PRESENT: Possible copper; possible iron, lead, zinc, cadmium, fluorite, and barite at depth

COMMENTARY AND SUMMARY: This tract is in the fold-dominated part of the Valley and Ridge. The rocks are quite favorable for $0 i 1$ and gas, al though some hydrocarbons may have been driven off by heat from metamorphism and igneous activity in the nearby Blue Ridge, heat that also made gas more common than oil throughout the province. These hydrocarbons are produced in several places in the province in the study area. This tract has unusually high favorability for petroleum because of its location with respect to a gas-producing anticline. Sandstone units may be favorable for uranium. The rocks are too old to contain coal: Hot dry rock at depth may be favorable as a source of geothermal energy. The Upper Devonian red beds at the surface may contain the critical mineral copper. Critical minerals for which the subsurface rocks may be favorable include zinc and lead (Devonian Oriskany Sandstone); iron (Devonian Helderberg Limestone and Silurian Clinton Formation); and zinc, cadmium, lead, fluorite, and barite (Ordovician carbonates). Little exploration has occurred for any commodity except for oil and gas, which has been only moderate.

GEOLOGY: Surface rocks are Upper Devonian and Lower Mississippian shales and sandstones on east flank of an anticline.

REFERENCE/CITATION: A1 1 resources - Stose and Ljungstedt, 1932, Gcol. Map of W. Va.; USGS and USBM, Iyb8, UStis Prot. Paper $580 ;$; Miller and Uthers, Iy/U, Mineral Kes. of the IVA Region; Brobst and Pratt, 1973, USGS Prof. Paper 820; DOE, 1978, Energy Res. Assessments of RARE II Lands; DOE, 1978, Energy Res. Assessments of Ten Alternatives - RARE II Lands; USFS, 1978, RARE II DES, So. Appal. Suppl, 0 il and Gas - Vlissides and Quirin, 1963, $0 i 1$ and Gas Fields of the U.S.; Cardweli, 1971, AAPG Mem. 15 ; USGS, 1974 and 1975, Maps of Appal. 0 il and Gas Production; Miller and Others, 1975, USGS Circ. 725; Harris and Milici, 1977, USGS Prof. Paper 1018; Patchen and 0thers, 1978, AAPG Bul1. 62: 1399-1441 Uranium - ERDA, 1976, NURE Preliminary Report. Coal - Trumbu11, 1960, Coal Fields of the U.S. Geothermal - AAPG, 1976a and b, Geothermal Gradient Map and Subsurface Temperature Map of North America. 
ENERGY AND MINERAL RESOURCE EVALUATION - RARE II TRACTS

TRACT NO: 09052

TRACT NAME: LittTe Mountain

ECOREG: 2214

WAR: 20

NATIONAL FOREST: Monongahela

STATE/COUNTY: West Virginia, Pocahontas

ACREAGE (GROSS): 8,440 ACREAGE (NET): $8,440 \quad 100 \mathrm{~N} / \mathrm{G}: 100$ LATITUDE: $38^{\circ} 28^{\prime}$ LONGITUDE: $79^{\circ} 57^{\prime}$

\begin{tabular}{|c|c|c|}
\hline $\begin{array}{l}\text { INDIVIDUAL TRACT } \\
\text { RESOURCE RATINGS } \\
\end{array}$ & $\underline{\text { ORNL }}$ & USFS \\
\hline OIL AND GAS & $4 / 2$ & 1 \\
\hline URANIUM & $2 / 1$ & 1 \\
\hline COAL & $\cdot 1 / 4$ & 1 \\
\hline GEOTHERMAL & $2 / 1$ & 1 \\
\hline CRITICAL MINERALS & $2 / 1$ & 1 \\
\hline $\begin{array}{l}\text { OVERALL RATING } \\
\text { (WEIGHTED) }\end{array}$ & 2 & \\
\hline
\end{tabular}

NAMES OF CRITICAL MINERALS PRESENT: Possible copper; possible iron, lead, zinc, cadmium, barite, and filuorite at depth

COMMENTARY AND SUMMARY: This tract is in the fold-dominated part of the Valley and Ridge. The rocks are quite favorable for $0 i l$ and gas, al though some hydrocarbons may have been driven off by heat from metamorphism and igneous activity in the nearby Blue Ridge, heat that also made gas more common than oil throughout the province. These hydrocarbons are produced in several places in the province in the study area. This tract has unusually high favorability for petroleum because of its location with respect to a gas-producing anticline. Sandstone units may be favorable for uranium. The rocks are too old to contain coal. Hot dry rock at depth may be favorable as a source of geothermal energy. The Upper Devonian red beds at the surface may contain the critical mineral copper. Critical minerals for which the subsurface rocks may be favorable include zinc and lead (Devonian Oriskany Sandstone); iron (Devonian Helderberg Limestone and Silurian Clinton Formation); and zinc, cadmium, lead, fluorite, and barite (Ordovician carbonates). Little exploration has occurred for any commodity except for oi] and gas, which has been only moderate.

GEOLOGY: Surface rocks are Upper Devonian shales and sandstones on the northwestern flank of an anticline.

REFERENCE/CITATION: A11 resources - Stose and Ljungstedt, 1932, Geol. Map of W. Va.; USGS and USBM, 1968, USGS Prof. Paper 580; MilTer and Others, 1970, Mineral Res. of the TVA Region; Brobst and Pratt, 1973, USGS Prof. Paper 820; DOE, 1978, Energy Res. Assessments of RARE II Lands; DOE, 1978, Erlergy Res. Assessments of Ten Alternatives - RARE II Lands; USFS, 1978, RARE II DES, So. Appal. Supp1. 0il and Gas - Vlissides and Quirin, 1963, 0il and Gas Fields of the U.S.; Cardwe11, 1971, AAPG Mem. 15; USGS, 1974 and 1975, Maps of Appal. Oil and Gas Production; Miller and Ot.hers, 1975, USGS Circ. 725; Harris and Milici, 1977, USGS Prof. Paper 1018; Patchen and Others, 1978, AAPG Bul1. 62: 1399-1441. Uranium - ERDA, 1976, NURE Prel iminary Report. Coal - Trumbul1, 1960, Coal Fields of the U.S. Geothermal - AAPG, 1976a and b, Geothermal Gradient Map and Subsurface Temperature Map of North America. 
ENERGY AND MINERAL RESOURCE EVALUATION - RARE II TRACTS

TRACT NO: 09326

TRACT NAME: East Fork of Greenbrier

ECOREG: 2214

WAR: 19

NATIONAL FOREST: Monongahela

STATE/COUNTY: West Virginia, Pocahontas

ACREAGE (GROSS): 6,810 ACREAGE (NET): 6,810

$100 \mathrm{~N} / \mathrm{G}: 100$ LATITUDE: $38^{\circ} 36^{\prime}$ LONGITUDE: $79^{\circ} 42^{\prime}$

\begin{tabular}{lcccc}
$\begin{array}{l}\text { INDIVIDUAL TRACT } \\
\text { RESOURCE RATINGS }\end{array}$ & ORNL & USFS & DOE & USGS \\
\cline { 1 - 3 } OIL AND GAS & $4 / 2$ & 1 & & \\
URANIUM & $2 / 1$ & 1 & 1 \\
COAL & $1 / 4$ & 1 & 2 \\
GEOTHERMAL & $2 / 1$ & 1 & \\
$\begin{array}{l}\text { CRITICAL MINERALS } \\
\begin{array}{l}\text { OVERALL RATING } \\
\text { (WEIGHTED) }\end{array}\end{array}$ & $2 / 1$ & 1 & \\
\end{tabular}

NAMES OF CRITICAL MINERALS PRESENT: Possible copper; possible iron, zinc, lead, cadmium, barite, and fluorite at depth

COMMENTARY AND SUMMARY: This tract is in the fold-dominated part of the Valley and. Ridge. The rocks are quite favorable for $0 i l$ and gas, although some hydrocarbons may have been driven off by heat from metamorphism and igneous activity in the nearby Blue Ridge, heat that also made gas more common than oil throughout the province. These hydrocarbons are produced in several places in the province in the study area. This tract has unusually high favorability for petroleum because of its location. with respect to a gas-producing anticline. Sandstone units may be favorable for uranium. The rocks are too old to contain coal. Hot dry rock at depth may be favorable as a source of geothermal energy. The Upper Devonian red beds at the surface may contain the critical mineral copper. Critical minerals for which the subsurface rocks may be favorable include zinc and lead (Devonian Oriskany Sandstone); iron (Devonian Helderberg Limestone and Silurian Clinton Formation); and zinc, cadmium, lead, fluorite, and barite (Ordovician carbonates). Little exploration has occurred for any commodity except for oil and gas, which has been only moderate.

GEOLOGY: Surface rocks are Upper Devonian shales and sandstones at the southwestern end of a northeastern plunging syncline, Western Valley and Ridge tract.

REFERENCE/CITATION: A11 resources - Stose and Ljungstedt, 1932, Geol. Map of W. Va.; USGS and USBM, 1968, USGS Prof. Paper 580; Miller and Others, 1970, Mineral Res. of the TVA Region; Brobst and Pratt, 1973, USGS Prof. Paper 820; DOE, 1978, Energy Res. Assessments of RARE II Lands; DOE, 1978, Energy Res. Assessments of Ten Alternatives - RARE II Lands; USFS, 1978, RARE II DES, So. Appal. Suppl. $0 i 1$ and Gas - Vlissides and Quirin, 1963, 0il and Gas Fields of the U.S.; Cardwel1, 1971, AAPG Mem. 15; USGS, 1974 and 1975, Maps of Appa1. 0il and Gas Production; Miller and Others, 1975, USGS Circ. 725; Harris and Milici, 1977, USGS Prof. Paper 1018; Patchen and Others, 1978, AAPG Bu11. 62: 1399-1441. Uranium - ERDA, 1976, NURE Prel iminary Report. Coal - Trumbu11, 1960, Coal Fields of the U.S. Geothermal - AAPG, 1976a and b, Geothermal Gradient Map and Subsurface Temperature Map of North America. 
ENERGY AND MINERAL RESOURCE EVALUATION - RARE II TRACTS

TRACT NO: 09327

TRACT NAME: Dolly Sods Roaring Plain

ECOREG: 2214

WAR: 12

NATIONAL FOREST: Monongahela

STATE/COUNTY: West Virginia, Randolph/Pendleton/

Tucker/Grant

ACREAGE (GROSS): 14,270 ACREAGE (NET): $11,270 \quad 100 \mathrm{~N} / \mathrm{G}: 79$ LATITUDE: $38^{\circ} 57^{\prime}$ LONGITUDE: $79^{\circ} 23^{\prime}$

INDIVIDUAL TRACT

RESOURCE RATINGS

$\underline{O R N L} \quad \underline{U S F S} \quad \underline{D O E} \quad \underline{\text { USGS }}$

REMARKS

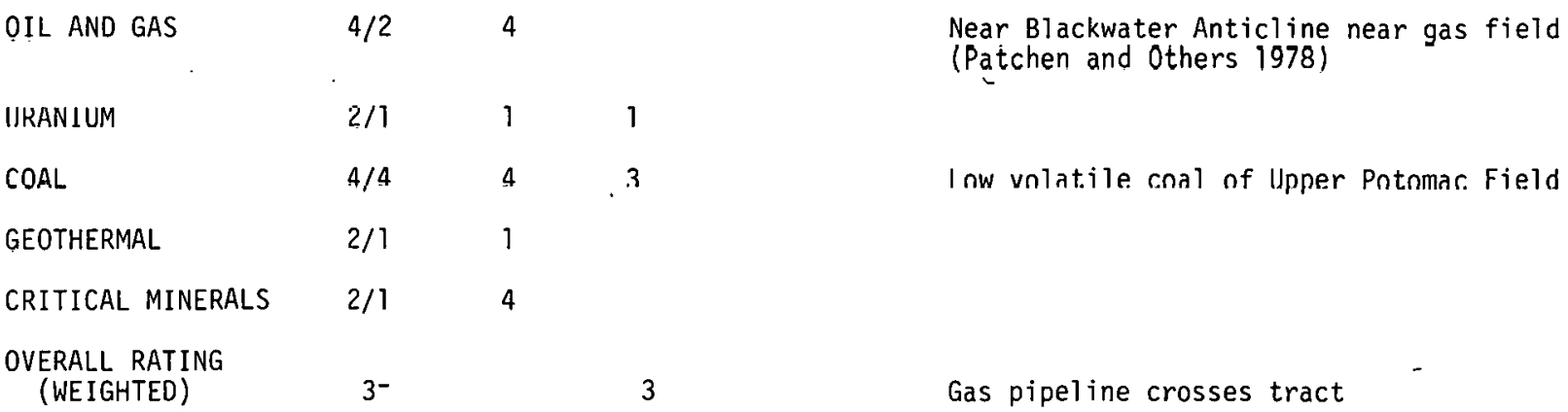

NAMES OF CRITICAL MINERALS PRESENT: Possible copper, iron, lead, zinc, cadmium, fluorite, and barite at depth

COMMENTARY AND SUMMARY: This tract is in the Appalachian Plateau. The rocks are very favorable for oil and gas, which are produced throughout the province. Sandstone units may be favorable for uranium. This tract is located within the Appalachian coal field and overlies thick, high-quality coal seams. Hot dry rock at depth may be favorable as a source of geothermal energy. The surface rocks contain no critical minerals. The subsurface rocks may be favorable for copper (Upper Devonian red beds); zinc and lead (Devonian Oriskany Sandstone); iron (Devonian Helderberg Limestone and Silurian Clinton Formation); and zinc, cadmium, lead, fluorite, and barite (Ordovician carbonates). Little exploration has been performed for all resources except for oil, gas, and coal in the immediate area.

GEOLOGY: Surface rocks are Mississippian and Pennsylvanian shales and sandstones synclinally folded.

REFERENCE/CITATION: All resources - Stose and Ljungstedt, 1932, Geol. Map of W. Va.; USGS and USBM, 1968, USGS Prof. Paper 580; Miller and Others, 1970, Mineral Res. of the TVA Region; Brobst and Pratt, 1973, USGS Prof. Paper 820; D0E, 1978, Energy Res. Assessments of RARE II Lands; DOE, 1978, Energy Res. Assessments of Ten Alternatives - RARE II Lands; USFS, 1978, RARE II DES, So. Appal. SuppI. 0i1 and Gas - Vlissides and Quirin, 1963, 0il and Gas Fields of the U.S.; Cardwel1, 1971, AAPG Mem. 15; USGS, 1974 and 1975, Maps of Appal. 0il and Gas Production; Mililer and 00thers, 1975, USGS Circ. 725; Harris and Milici, 1977, USGS Prof. Paper 1018; Patchen and Others, 1978, AAPG Bu11. 62: 1399-i441. Uranium - ERDA, 1976, NURE Prel iminary Report. Coal - Trumbu11, 1960, Coal Fields of the U.S. Geothermal - AAPG, 1976a and b, Geothermal Gradient Map and Subsurface Temperature Map of North America. 
ENERGY AND MINERAL RESOURCE EVALUATION - RARE II TRACTS

INDIVIDUAL TRACT
RESOURCE RATINGS

OIL AND GAS

URANIUM

COAL

GEOTHERMAL

CRITICAL MINERALS

OVERALL RATING

(WEIGHTED)

\begin{tabular}{|c|c|c|c|}
\hline$\underline{\text { ORNL }}$ & $\underline{\text { USFS }}$ & $\underline{D E E}$ & USGS \\
\hline $4 / 2$ & 4 & & \\
\hline $2 / 2$ & 1 & 1 & \\
\hline $3 / 4$ & 4 & 3 & \\
\hline $2 / 1$ & 1 & & \\
\hline $2 / 2$ & 4 & & \\
\hline $3^{-}$ & & 3 & \\
\hline
\end{tabular}

NAMES OF CRITICAL MINERALS PRESENT: Possible copper, iron, zinc, lead, barite, and fluorite at depth

COMMENTARY AND SUMMARY: This tract is in the Appalachian Plateau province. The rocks are favorable for $0 i 1$ and gas, which are produced throughout the province in the study area. Sandstone units may be favorable for deposits of uranium. . This tract is situated on the edge of the Appalachian coal field. coal underlies part of the tract but is thin and of low quality. Hot dry rock at depth may be favorable as a source of geothermal energy. The surface rocks probably contain no critical minerals, but older rocks at depth may be favorable for copper (Upper Devonian red beds); zinc and lead (Devonian Oriskany Sandstone); iron (Devonian Helderberg Limestone and Silurian Clinton Formation); and zinc, cadmium, lead, fluorite, and barite (Ordovician.carbonates). Little exploration has occurred for any resources, except. for nil, gas, and coal in the immediate area.

GEOLOGY: Surface rocks are Upper Mississippian and Lower Pennsylvanian shales and sandstones, mostly flat-lying but with a few local folds and faults.

REFERENCE/CITATION: All resources - Stose and Ljungstedt, 1932, Geol. Map of W. Va.; USGS and USBM, 1968, USGS Prof. Paper 580; Miller and Others, 1970, Mineral Res. of the TVA Region; Brobst and Pratt, 1973, USGS Prof. Paper 820; DOE, 1978, Energy Res. Assessments of RARE II Lands; D0E, 1978, Energy Res. Assessments of Ten Alternatives - RARE II Lands; USFS, 1978, RARE II DES, So. Appal. Suppl. 0i1 and Gas - V1issides and Quirin, 1963, 0i1 and Gas Fields of the U.S.; Cardwel1, 1971, AAPG Mem. 15; USGS, 1974 and 1975, Maps of Appa 1. Oil and Gas Production; Miller and Others, 1975, USGS Circ. 725; Harris and Milici, 1977, USGS Prof. Paper 1018; Patchen and Others, 1978, AAPG Bul1. 62: 1399-1441. Uranium - ERDA, 1976, NURE Prel iminary Report. Coal - Irumbuli, 1960, CoaT Fields of the U.S. Geothermal - AAPG, 1976a and b, Geothermal Gradient Map and Subsurface Temperature Map of North America. 
ENERGY AND MINERAL RESOURCE EVALUATION - RARE II TRACTS

TRACT NO: 09329

TRACT NAME: Spice Run

ECOREG: 2214

WAR: 20

NATIONAL FOREST: Monongahela

STATE/COUNTY: West Virginia, Pocahontas/Greenbrier

ACREAGE (GROSS): 6,320 ACREAGE (NET) : $6,160 \quad 100 \mathrm{~N} / \mathrm{G}: 97$ LATITUDE: $38^{\circ} 02^{\prime}$ LONGITUDE: $80^{\circ} 12^{\prime}$

INDIVIDUAL TRACT RESOURCE RATINGS

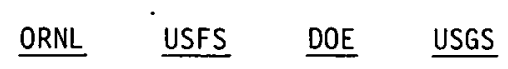

OIL AND GAS

UR.ANIUM

COAL

GEOTHERMAI.

CRITICAL MINERALS

OVERALL RATING

(WEIGHTED)

$4 / 2 \quad 1$

$\begin{array}{lll}2 / 1 & 1 & 1 \\ 1 / 4 & 1 & 3 \\ 2 / 1 & 1 & \\ 2 / 1 & 1 & \\ 2- & & \end{array}$

NAMES OF CRITICAL MINERALS PRESENT: Possible copper; possible iron, zinc, lead, cadmium, barite, and fluorite at depth

COMMENTARY AND SUMMARY: This tract is in the fold-dominated part of the Valley and Ridge. The rocks are quite favorable for 0 il and gas, al though some hydrocarbons may have been driven off by heat from metamorphism and igneous activity in the nearby Blue Ridge, heat that also made gas more common than oit throughout the province. These hydrocarbons are produced in several places in the province in the study area. This tract has unusually high favorability for petroleum because of its location with respect to a gas-producing anticline. Sandstone units may be favorable for uranium. The rocks are too old to contain coal. Hot dry rock at depth may be favorable as a source of geothermal energy. The Upper Devonian red beds at the surface may contain the critical mineral copper. Critical minerals for which the subsurface rocks may be favorable include zinc and lead (Devonian Oriskany Sandstone); iron (Devonian Helderberg Limestone and Silurian Clinton Formation); and zinc, cadmium, lead, fluorite, and barite (Ordovician carbonates). Little exploration has occurred for any commodity except for oil and gas, which has been only moderate.

GEOLOGY: Surface rocks are Upper Devonian and Lower Mississippian shales arid sandstones on the northwestern flank of an anticline.

REFERENCE/CITATION: A11 resources - Stose and Ljungstedt, 1932, Geol. Map of W. Va.; USGS and USBM, 1968, USGS Prof. Paper 580; Miller and Others, 1970, Mineral Res. of the TVA Region; Brobs.t and Pratt, 1973, USGS Prof. Paper 820; D0E, 1978, Energy Res. Assessments of RARE II Lands; D0E, 1978, Energy Res. Assessments of Ten A1ternatives - RARE II Lands; USFS, 1978, RARE II DES, So. Appal. Supp1. 0i1 and Gas - Vlissides and Quirin, 1963, 011 and Gas Fields of the U.S.; Cardwel1, 1971, AAPG Mem. 15; USGS, 1974 and 1975, Maps of Appal. 0il and Gas Production; Miller and Others, 1975, USGS Circ. 725; Harris and Milici, 1977, USGS Prof. Paper 1018; Patchen and 0thers, 1978, AAPG Bul1. 62: 1399-1441. Uranium - ERDA, 1976, NURE Preliminary Report. Coal - Trumbu11, 1960, Coal Fields of the U.S. Geothermal - AAPG, 1.976a and b, Geothermal Gradient Map and Subsurface Temperature Map of North America. 
ENERGY AND MINERAL RESOURCE EVALUATION - RARE II TRACTS

TRACT N0: 09331

TRACT NAME: Cranberry Addition

ECOREG: 2211

WAR: 15

NATIONAL FOREST: Monongahela

STATE/COUNTY: West Virginia, Webster/Pocahontas

ACREAGE (GROSS) : 9,840 ACREAGE (NET): 9,840

$100 \mathrm{~N} / \mathrm{G}: 100$ LATITUDE: $38^{\circ} 15^{\prime}$ LONGITUDE: $80^{\circ} 19^{\prime}$

INDIVIDUAL TRACT

RESOURCE RATINGS

OIL AND GAS

URANIUM

COAL

GEOTHERMAL

$\underline{\text { ORNL USFS DOE USGS }}$

REMARKS

CRITICAL MINERALS

$4 / 2 \quad 4$

OVERALL RATING

(WE IGIITED)

$2 / 2$

1

1

$3 / 4 \quad 4 \quad 3$

$2 / 1 \quad 1$

$2 / 2 \quad 4$

NAMES OF CRITICAL MINERALS PRESENT: Possible copper, iron, zinc, lead, cadmium, barite, and fluorite at depth

COMMENTARY AND SUMMARY: This tract is in the Appalachian Plateau province. The rocks are favorable for $0 i 1$ and gas, which are produced throughout the province in the study area. Sandstone units may be favorable for deposits of uranium. This tract is situated on the edge of the Appalachian coal field. coal underlies part of the tract but is thin and of low quality. Hot dry rock at depth may be favorable as a source of geothermal energy. The surface rocks probably contain no critical minerals, but older rocks at depth may be favorable for copper (Upper Devonian red beds); zinc and lead (Devonian Oriskany Sandstone); iron (Devonian Helderberg Limestone and Silurian Clinton Formation); and zinc, cadmium, lead, fluorite, and barite (Ordovician carbonates). Little exploration has occurred for any resources, except for 0 il, gas, and coal in the immediate area.

GEOLOGY: Surface rocks are Middle Silurian to Upper Devonian shales and sandstones on the northwestern Plalik of an anticline.

REFERENCE/CITATION: All resources - Stose and Ljungstedt, 1932, Geo1. Map of W. Va.; USGS and USBM, 1968, USGS Prof. Paper 580; Mi Tler and Others, 1970, Mineral Res. of the TVA Region; Brobst and Pratt, 1973, USGS Prof. Paper 820; DOE, 1978, Energy Res. Assessments of RARE II Lànds; D0E, 1978, Energy Res. Assessments of Ten Alternatives - RARE II Lands; USFS, 1978, RARE II DES, So. Appal. Supp,1. 0i1 and Gas - Vlissides and Quirin, 1963, 0il and Gas Fields of the U.S.; Cardwe11, 1971, AAPG Mem. 15; USGS, T974 and 1975, Maps of Appa1. Oil and Gas Production; Miller and Others, 1975, USGS Circ. 725; Harris and Milici, 1977, USGS Prof. Paper 1018; Patchen and 0thers, 1978, AAPG Bul1. 62: 1399-1441. Uranium - ERDA, 1976, NURE Preliminary Report. Coal - Trumbu11, 1960, Coal Fields of the U.S. Geothermal - AAPG, 1976a and b, Geothermal Gradient Map and Subsurface Temperature Map of North America. 
ENERGY AND MINERAL RESOURCE EVALUATION - RARE II TRACTS

TRACT NO: 09330

TRACT NAME: Marl in Mountain

ECOREG: 2214

WAR: 18

NATIONAL FOREST: Monongahela

STATE/COUNTY: West Virginia, Pocahontas

ACREAGE (GROSS): 8,640 ACREAGE (NET): $3,610 \quad 100 \mathrm{~N} / \mathrm{G}: 100$ LATITUDE: $38^{\circ} 14^{\prime}$ LONGITUNF: 8000'

INDIVIDUAL TRACT RESOURCE RATINGS

OIL AND GAS

ORNL

$\underline{\text { USFS }}$

$\underline{D O E}$

USGS

$4 / 2$

1

URANIUM

COAL

GEOTHERMAL

CRITICAL MINERALS

$2 / 1$

$1 / 4$

$2 / 1$

$3 / ?$

1

(WEIGHTED)

\section{$3^{-}$}

REMARKS

On Brown's Mountoin Anticline, which is on strike with gas-bearing Blackwater Anticline (Patchen and Others 1978)

Mineral-bearing rocks are ncar or at the surface. Black shales may have zinc and lead

NAMES OF CRITICAL MINERALS PRESENT: Possible manganese, iron, zinc, lead, and copper; possible lead, zinc, cadmium, fluorite, and barite at depth

COMMENTARY AND SUMMARY: This tract is in the fold-dominated part of the Valley and Ridge. The rocks are quite favorable for oil and gas, al though some hydrocarbons may have been drivell uff by heat from met.amnrphism and igneous activity in the nearby Blue Ridge, heat that also would make gas more common than oil throughout the province. These hydrocarbons are produced in several localities in the province in the study area. This tract has unusually high favorability because of 1 ts location with respect to a gas-producing anticline. Sandstone units may be favorable for deposits of uranium. The rocks are too old to contain coal. Hot dry rock at depth may be favorable as a source of geothermal energy. The surface rocks are quite favorable for critical minerals: copper in the Upper Devonian red beds; manganese, iron, zinc, and lead in the weathered Devonian Oriskany Sandstone; iron in the Devonian Helderberg Limestone; and 1ron in the Siluriall Clinton Formation. Zinc, lcad, cadmium, fluorite, and barite may also be present in Ordovician carbonates below the surface. Little exploration has been performed for all commodities except for oil and gas, and only moderate amounts for them.

GEOLOGY: This tract is in the fold-dominated Valley and Ridge. Surface rocks are Middle Silurian to Upper Devonian shales and sandstones on the northwestern flank of an anticline.

REFERENCE/CITATION: All resources - Stose and Ljungstedt, 1932, Geol. Map of W. Va.; USGS and USBM, 1968, USGS Prof. Paper 580; MiTTer and 0thers, 1970, Mineral Res. of the TVA Region; Brobst and Pratt, 1973, USGS Prof. Paper 820; DOE, 1978, Energy Res. Assessments of RARE II Lands; D0E, 1978, Energy Res. Assessments of Ten Alternatives - RARE II Lands; USFS, 1978, RARE II DES, So. Appal. Suppl. Dil and Gas - V1issides and Quirin, 1963, 0il and Gas Fields of the U.S.; Cardwe11, 1971, AAPG Mem. 15; USGS, 1974 and 1975, Maps of Appal. 011 and Gas Production; Miller and Others, 1975, USGS Circ. 725; Harris and Milici, 1977, USGS Prof. Paper 1018; Patchen and Others, 1978, AAPG. Bul1. 62: 1399-1441. Uranium - ERDA, 1976, NURE Prel iminary Report. Coal - Trumbu11, 1960, Coal Fields of the U.S. Geothermal - AAPG, 1976a and b, Geothermal Gradient Map and Subsurface Temperature Map of North America. 
INTERNAL DISTRIBUTION

1. S. I. Auerbach

2. J. S. Baldwin

3. I. Brogden

4. B. H. Bronfman

5. R. L. Burgess

6. R. S. Carlsmith

7. R. M. Davis

8-17. J. E. Dobson

18. W. Fulkerson

19. M. E. Hodgson

20. R. B. Honea

21. T. Kitchings

22. J. M. Klopatek

23. S. Konkel

24. K. Oakes
25. J. 01 son

26. R. J. 01 son

27. D. E. Reichle

28. T. H. Row

29. P. Scheffler

30. J.W. Sims

31. W. P. Staub

32-81. A. H. Voelker

82. T. J. Wilbanks

83-84. Central Research Library

85. Document Reference Section

86-87. Laboratory Records

88. Laboratory Records (RC)

89. ORNL Patent Office

90-92. Technical Publications Dept.

EXTERNAL DISTRIBUTION

93. Office of Assistant Manager, Energy Research and Development, Oak Ridge Operations, Department of Energy, Oak Ridge, TN 37830

94-224. Regional and Urban Studies and Resource Analysis Group Distribution Lists

225-251. Technical Information Center, Department of Energy, P.0. Box 62, Oak Ridge, TN 37830 